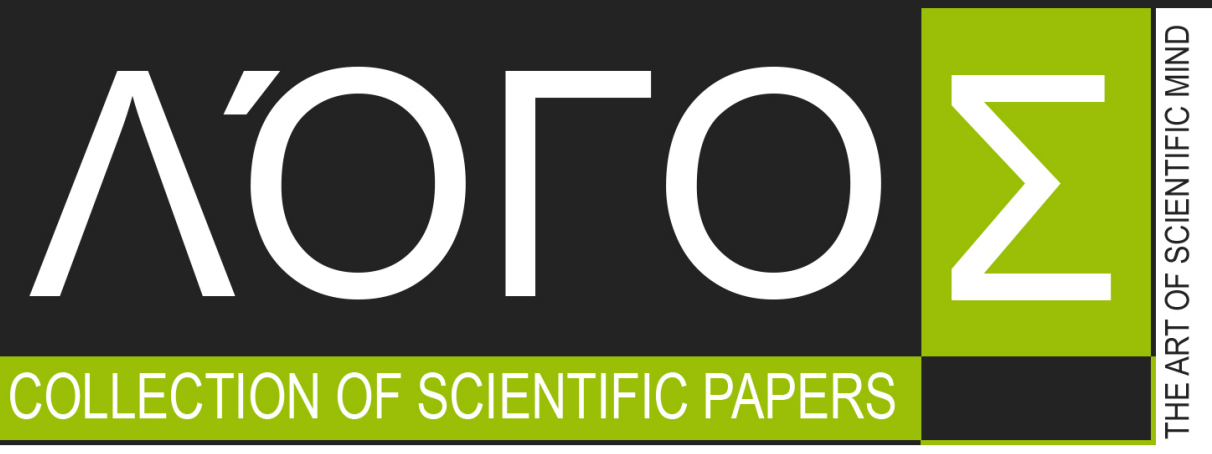

WITH PROCEEDINGS OF THE INTERNATIONAL SCIENTIFIC AND PRACTICAL CONFERENCE

\title{
PROBLEMS AND PROSPECTS OF IMPLEMENTATION OF INNOVATIVE RESEARCH RESULTS
}

DECEMBER 13, 2019•VALLETTA, MALTA —

\section{VOLUME 2}

DOI 10.36074/13.12.2019.v2

ISBN 978-617-7171-91-0

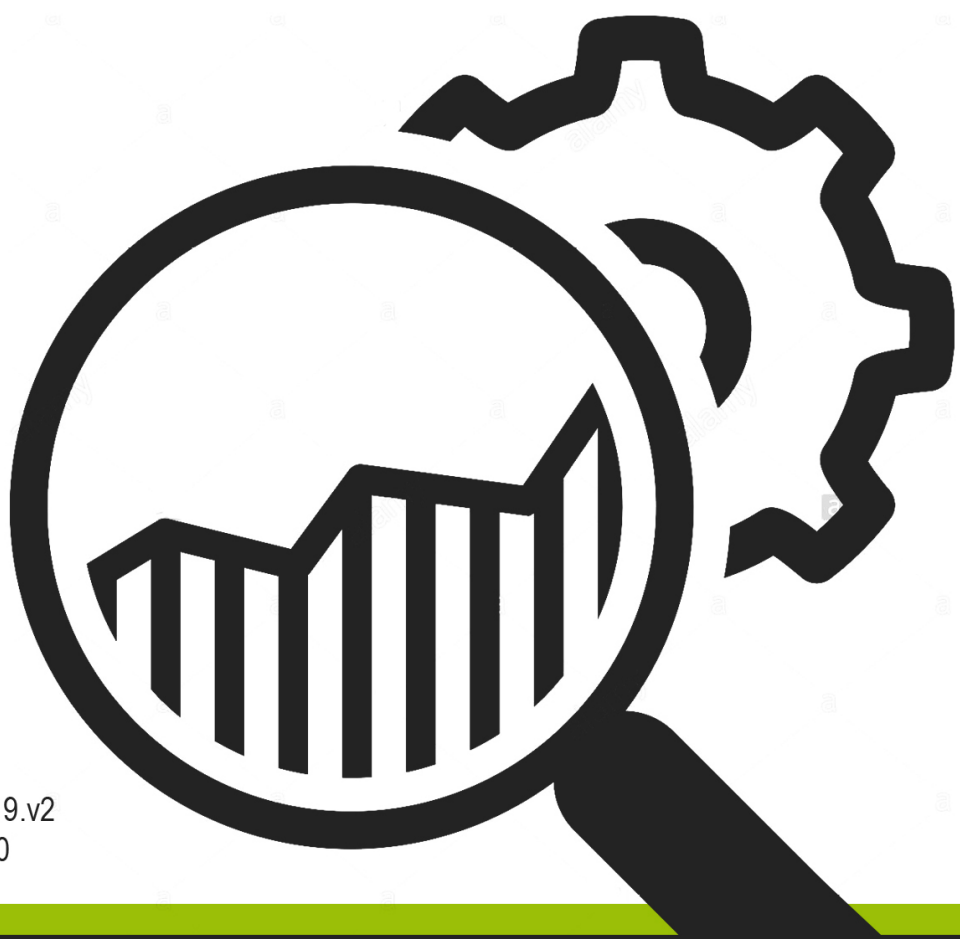



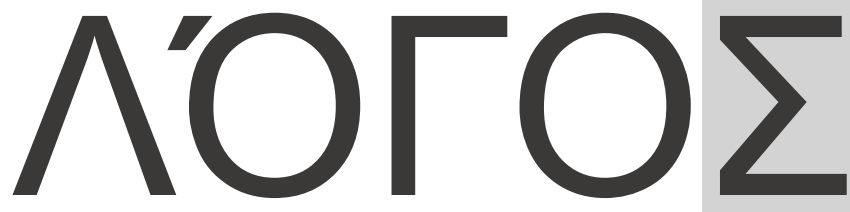

COLLECTION OF SCIENTIFIC PAPERS

WITH PROCEEDINGS OF THE INTERNATIONAL SCIENTIFIC AND PRACTICAL CONFERENCE «PROBLEMS AND PROSPECTS OF IMPLEMENTATION OF INNOVATIVE RESEARCH RESULTS»

DECEMBER 13, 2019

\section{VOLUME 2}

Valletta $\bullet$ Republic of Malta 
P 93

Chairman of the Organizing Committee: Holdenblat M.

Responsible for the layout: Kazmina $\mathrm{N}$.

Responsible designer: Bondarenko I.

P 93 Problems and prospects of implementation of innovative research results: collection of scientific papers "АОГО $\Sigma$ » with Proceedings of the International Scientific and Practical Conference (Vol. 2), December 13, 2019. Valletta, Republic of Malta: European Scientific Platform NGO.

ISBN 978-617-7171-91-0

DOI 10.36074/13.12.2019.v2

Papers of participants of the International Multidisciplinary Scientific and Practical Conference «Problems and prospects of implementation of innovative research results», held in Valletta, December 13, 2019, are presented in the collection of scientific papers.

The conference is included in the catalog of International Scientific Conferences, approved by ResearchBib and certified by Euro Science Certification Group (SCC-2000).

Conference proceedings are publicly available under terms of the Creative Commons Attribution 4.0 International License (CC BY 4.0).

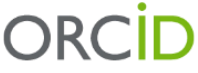

Connecting Research and Researchers

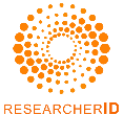

RESEARCHERID
Bibliographic descriptions of the conference proceedings are available for indexation by ORCID, Publons, Google Scholar, ets.

(C) Participants of the conference, 2019 
December 13, $2019 \bullet$ Valletta, Republic of Malta $\bullet \mathbf{3}$

\section{SECTION I. ECONOMICS}

\section{CONTENT}

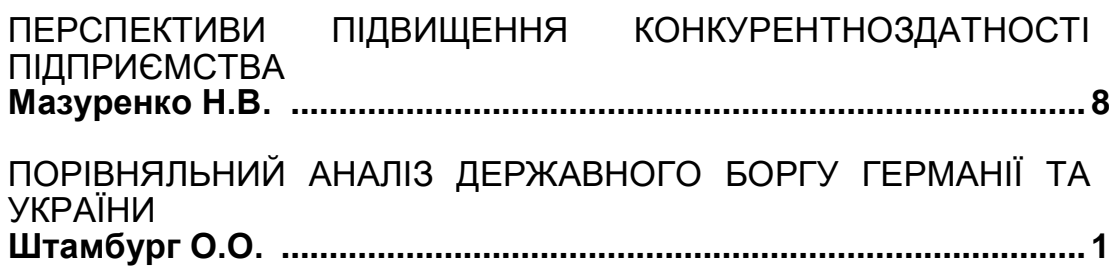

ПОРІВНЯЛЬНИЙ АНАЛІЗ МОДЕЛЕЙ БУХГАЛТЕРСЬКОГО ОБЛІКУ, ЗАСТОСОВУВАНИХ В СВІТОВІЙ ПРАКТИЦІ

Фурман Д.В.

ПРИЧИНИ ТРУДОВОЇ МІГРАЦІЇ МОЛОДІ УКРАЇНИ

Михайлишена К.П.

РЕГУЛЮВАННЯ ІНФЛЯЦІЙНИХ ПРОЦЕСІВ

Бевз Я.Ю.

РОЛЬ ФІНАНСОВИХ МЕНЕДЖЕРІВ В СУЧАСНИХ УМОВАХ ВЕДЕННЯ БІЗНЕСУ

Романчук P.A.

СВІТОВИЙ ДОСВІД ФІНАНСОВОЇ ПІДТРИМКИ СУБ'ЄКТІВ МАЛОГО БІЗНЕСУ В КОНТЕКСТІ РОЗВИТКУ КОНКУРЕНТОСПРОМОЖНОСТІ ТРУДОВОГО ПОТЕНЦІАЛУ РЕГІОНУ

Мазуренко Н.В., Серікова О.М.

СИСТЕМА ДЕРЖАВНИХ ЗАКУПІВЕЛЬ ТА ІІІ ФУНКЦІОНУВАННЯ

Бевз Я.Ю.

СУЧАСНИЙ СТАН ФІНАНСОВОГО РИНКУ УКРАЇНИ

Штамбург 0.0.

СУЧАСНІ РЕАЛІЇ ТА ТЕНДЕНЦІЇ РОЗВИТКУ СТРАХОВОГО РИНКУ УКРАЇНИ

Бинда Г.В.

ФИНАНСОВОЕ ПРЕДПРИЯТИЙ

ОБЕСПЕЧЕНИЕ

ТУРИСТИЧЕСКИХ

Бондарь Ю.А., Шестина Е. 
4 - Problems and prospects of implementation of innovative research results $\bullet$ Volume 2

SECTION II.

\section{AGRICULTURAL SCIENCES}

АСОЦІАЦІЯ МІЖ РОСТОВИМИ ОЗНАКАМИ М'ЯСНОЇ ХУДОБИ ТА ГЕНЕТИЧНИМ ПОЛІМОРФІЗМОМ МІКРОСАТЕЛІТНОЇ ДНК

Крамаренко О.С.

ЕФЕКТИВНІСТЬ ВИРЩУВАННЯ БУРЯКА СТОЛОВОГО ПУЧКОВОЇ СТИГЛОСТІ

Стефанюк С.В.

ЗБЕРЕЖЕННЯ ГІРСЬКОЇ ЛОКАЛЬНОЇ ПОРОДИ ПІНЦГАУ В КАРПАТСЬКОМУ РЕГІОНІ УКРАЇНИ

Науково-дослідна група:

Калинка А.К., Лесик О.Б., Саранчук І.І.

\section{SECTION III. \\ PUBLIC ADMINISTRATION AND ECOLOGY}

ПЕРСПЕКТИВИ ТА ПЕРЕВАГИ РЕЦИКЛІЗАЦІЇ БУДІВЕЛЬНИХ ВІДХОДІВ

Костюкова М.О.

ПРИНЦИПИ ПОБУДОВИ СТАЛОЇ СИСТЕМИ ПОВОДЖЕННЯ 3 ТВЕРДИМИ ПОБУТОВИМИ ВІДХОДАМИ В УКРАЇНІ

Корбут М.Б., Герасимчук О.Л.

\section{SECTION IV.}

\section{ENGINEERING AND IT}

ASPECTS OF LIGHTNING NETWORK PAYMENT PROTOCOL IMPLEMENTATION

Vlasov A.

IMPROVEMENT OF METHOD, MODEL OF ARCHITECTURALLY INDEPENDENT HARDWARE PLATFORMS

Дуда Л.Т., Вознюк Ю.І.

АНАЛІЗ СПОСОБІВ ЗМЕНШЕННЯ ВПЛИВУ ЗНОСУ ТА ТОЧНОСТІ ВИГОТОВЛЕННЯ ДВООПОРНИХ ЗАМКОВИХ РІЗЬБОВИХ З'ЄДНАНЬ ОБВАЖНЕНИХ БУРИЛЬНИХ ТРУБ Науково-дослідна група:

Михайлюк В.В, Фафлей О.Я., Дейнега P.О., Юрич А.P., Семенчук А.В. 
ВПЛИВ ВИКОНАННЯ ТЕХНОЛОГІЧНИХ ОПЕРАЦІЙ В ПРОЦЕСІ БУРІННЯ СВРДЛОВИН НА ЗМІНУ ВИБІЙНОГО ТИСКУ

Науково-дослідна група:

Лях М.М., Концур І.Ф., Михайлюк В.В., Дейнега Р.О., Клицюк В.O.

ДОСЛІДЖЕННЯ СИНТЕЗОВАНИХ ТЕРМОПЕРЕВОДНИХ ОРГАНІЧНИХ БАРВНИКІВ I ІХ ВИКОРИСТАННЯ

Науково-дослідна група:

Вигоняйло О.І., Попов Є.В., Мороз О.В.

ДОСЛІДЖЕННЯ ЗАСОБІВ ВІЗУАЛЬНОГО ПРОГРАМУВАННЯ ДЛЯ РОЗРОБКИ АНІМАЦІЙ НАУКОВОГО СПРЯМУВАННЯ

Науково-дослідна група:

Кічатов О.С., Селівьорстова Т.В., Селівьорстов В.Ю.

ДОСЛІДЖЕННЯ ТА ПОРІВНЯЛЬНИЙ АНАЛІЗ МЕТОДІВ ВИРІШЕННЯ ЗАДАЧІ КОМІВОЯЖЕРА

Решетник B.P.

ЕКСПРЕС ОЦНЮВАННЯ ЙМОВІРНОГО ПРОГИНУ ЕЛЕКТРОНАСОСНОГО АГРЕГАТУ НА ХАРАКТЕРНИХ ДІЛЯНКАХ СВЕРДЛОВИНИ

Науково-дослідна група:

Джус А.П., Михайлюк В.В., Дейнега Р.О., Коник А.М.

ЖАДНЫЕ АЛГОРИТМЫ РАЗМЕЩЕНИЯ ПРЯМОУГОЛЬНИКОВ НА ПОЛУБЕСКОНЕЧНОЙ ЛЕНТЕ

Гуляницький Л.Ф., Дубина А.В.

ОСОБЛИВОСТІ ЗАХИСТУ ДАНИХ НА ВЕРСТАТІ З ЧПК FАNUС Науково-дослідна група:

Задвірний М.С., Литвиненко М.С., Захарова М.В., Литвиненко Д.С.

ЗАСТОСУВАННЯ ІНТЕЛЕКТУАЛЬНОГО АНАЛІЗУ ДАНИХ КОРИСТУВАЧІВ ЗА ДОПОМОГОЮ АЛГОРИТМІВ КЛАСТЕРИЗАЦІЇ

Тимошик М.B.

ІННОВАЦІЙНІ МЕТОДИ ВИКЛАДАННЯ ОБЛІКОВИХ ДИСЦИПЛІН: ХМАРНІ ТЕХНОЛОГІІ

Бабінська К.Л.

МЕТОДОЛОГІЯ ПОБУДОВИ СИСТЕМ ТЕРМОСТАТУВАННЯ ОБ'ЄКТІВ РАКЕТИ-НОСІЯ

Булавка С.С. 
6 • Problems and prospects of implementation of innovative research results $\bullet$ Volume 2

НАУКОВИЙ ТЕКСТ ЯК СТРАТЕГІЧНИЙ ЗАСІБ НАУКОВОЇ КОМУНІКАЦІЇ

Шевчук 0.

OРІЕНТОВНІ НАПРЯМИ ПІДВИЩЕННЯ ЕФЕКТИВНОСТІ СИЛОВОГО ПРИВОДА БУРОВОЇ УСТАНОВКИ 3 ДВИГУНАМИ ВНУТРІШНЬОГО ЗГОРАННЯ

Науково-дослідна група:

Лях М.М., Михайлюк В.В., Дейнега Р.О., Малик В.Я., Маланин I.I.

ОСНОВИ ОРГАНІЗАЦІЇ ВИРОБНИЦТВА КУЛІНАРНОЇ ПРОДУКЦІЇ ТА ПРОДУКТІВ ХАРЧУВАННЯ НА ПІДПРИЕМСТВАХ МАСОВОГО ХАРЧУВАННЯ

Шевчук 0. 99

ПЕРЕВАГИ । ПЕРСПЕКТИВИ ВИКОРИСТАННЯ ХМАРНИХ ТЕХНОЛОГІЙ У ОСВІТНЬОМУ ПРОЦЕСІ

Лисенко Н.П.

РОЗРОБКА ТЕХНОЛОГІЇ ТА ОБЛАДНАННЯ ДЛЯ ТЕРМІЧНОЇ ОБРОБКИ МЯСНИХ ПАШЕТІВ Науково-дослідна група:

Приліпко Т.М., Гончар В.І., Пустова Н.В., Калинка А.К. 101

СТРУКТУРА ВИРОБНИЦТВА ХАРЧОВОЇ ПРОДУКЦІї

Вознесенський Д. 105

TEOРЕТИЧНІ OСНОВИ FOODPAIRING

Лінова 0.

УДОСКОНАЛЕННЯ АЛГОРИТМУ ФІЛЬТРАЦІЇ ЦИФРОВИХ ЗОБРАЖЕНЬ ЗА ДОПОМОГОЮ СПЛАЙНОВОГО ФІЛЬТРУ В СЕРЕДОВИЩІ МАТLAB

Кривенко І.М.

ФЕРМЕНТАТИВНА АКТИВНІСТЬ ШВИДКОЗАМОРОЖЕНОГО ДЕСЕРТУ ФУНКЦІОНАЛЬНОГО ПРИЗНАЧЕННЯ НА ОСНОВІ ГАРБУЗА

Науково-дослідна група:

Заболотна А.В., Заболотний О.І., Лобода А.Ю.

\section{SECTION V. MEDICINE}

COMPLICATIONS OF PREGNANCY AND LABOR OF WOMEN WITH 
HYPERTENSION

Deinichenko O., Kruty Y.

FEATURES OF EATING DISORDERS IN YOUNG PEOPLE

Gevorgyan S., Goncharenko V.

THE CONTRIBUTION OF MIKHAIL IVANOVICH RAYSKY TO THE DEVELOPMENT OF GLOBAL MEDICINE

Research group:

Yakushev Y., Kikosh K., Hizhnjak V.

THE EFFECT OF IMPLANTATION OF CRYOPRESERVED PLACENTAL EXPLANTS ON ADAPTATION AND COGNITIVE FUNCTIONS OF FEMALE MICE IN THE MODEL OF DYSCIRCULATORY ENCEPHALOPATHY

Research group:

Musatova I., Chub O., Tynynyka L., Nikolchenko A.

ВПЛИВ ОЛІЇ АМАРАНТУ НА ЗМІНИ СТРУКТУРНОMЕТАБОЛІЧНОГО КОНТИНУУМА У ЩУРІВ $3 \quad \mathrm{CCL}_{4}$ ОБУМОВЛЕНОЮ ІНТОКСИКАЦІЮЮ

Татаріна О.В.

ОСОБЛИВОСТІ ПАТОГЕНЕЗУ ГЕСТАЦІЙНОГО ЦУКРОВОГО ДІАБЕТУ

Шарун С.Н., Лісова Є.M.

ПРОБЛЕМА ЛІКУВАННЯ МУЛЬТИРЕЗИСТЕНТНОГО

ТУБЕРКУЛЬОЗУ У ВАГІТНИХ

Науково-дослідна група:

Полякова В.В., Лєсна А.С., Бутов Д.О.

СТАБИЛИЗАЦИЯ РЕФРАКЦИИ ПРИ ПОМОЩИ ОРТОКЕРАТОЛОГИИ

Дащук А.А., Деркач Ю.В.

СУЧАСНІ ПІДХОДИ ДО ЛІКУВАННЯ ЛЕЙКОПЛАКІЇ СЕЧОВОГО MIXУPA

Гордієнко П.О., Стоян А.О.

\section{SECTION VI. PHARMACY}

ГИПОЛИПИДЕМИЧЕСКАЯ И АНТИАТЕРОСКЛЕРОТИЧЕСКАЯ АКТИВНОСТЬ БИОЛОГИЧЕСКИ АКТИВНЫХ ВЕЩЕСТВ ЧЕСНОКА ПОСЕВНОГО

Научно-исследовательская группа:

Столетов Ю.В., Куценко Т.А., Уланова В.А., Белик Г.В. 


\title{
SECTION I. ECONOMICS
}

\section{ПЕРСПЕКТИВИ ПІДВИЩЕННЯ КОНКУРЕНТНОЗДАТНОСТІ ПІДПРИЄМСТВА}

\author{
Мазуренко Наталія Володимирівна \\ студентка відділення фінансів, обліку та маркетингу \\ Торговельно-економічний коледж \\ Київського національного торговельно-економічного університету \\ УКРАÏHA
}

Працівників підприємства доцільно розглядати не просто як найманий персонал, а як соціальних партнерів по бізнесу. Конкурентоздатність персоналу і проявляється у результаті спільної участі працівників у трудовому процесі, спеціалізації, кооперації праці, розвитку ефективних економічних та соціальних відносин.

Конкурентоздатність персоналу формується як інтегральний показник тих якостей, за рахунок яких саме працівник $є$ кращим за інших на визначеній посаді з точки зору організації, і за рахунок яких організація надає йому перевагу. Так, конкурентоспроможність працівника, за словами Грішнової О.А. - це відповідність якості робочої сили потребам ринку, можливість перемагати в конкуренції на ринку праці, тобто повніше порівняно з іншими кандидатами задовольняти вимоги роботодавців за рівнем знань, умінь, навичок, особистих рис [1].

Провідна роль у підвищенні конкурентоспроможності персоналу належить підприємству. Саме на рівні підприємства розробляються різні методи, що сприяють розвитку ділових і професійно значущих якостей у співробітників. Одним із напрямів забезпеченням конкурентоспроможності персоналу $є$ попередня професійна діагностика нового персоналу, яка виступає головним інструментом ефективного управління персоналом і ключовим моментом сертифікації кадрів вже на етапі відбору та підбору кадрів. Проведення регулярної діагностики не тільки нового персоналу, але й постійного дозволить визначати пріоритети розвитку працівників, прогнозувати і планувати їх кар'єру.

У результаті проведення оціночної процедури підприємство отримує інформацію про конкурентоспроможність кожного співробітника, після чого може переходити до розробки конкретних заходів, спрямованих на підвищення його рівня. При цьому розробка конкретних передбачає формування фонду витрат, які підприємство може і хоче виділити на процедуру формування конкурентоспроможності персоналу. Ці заходи залежать від наступних умов: фінансового стану підприємства; стану ринку праці регіону, в якому функціонує підприємство; отриманих в ході оцінки показники рівня конкурентоспроможності персоналу; ступеня зацікавленості керівництва підприємства у розвитку конкурентних переваг свого персоналу. 
Основоположним елементом фрормування конкурентоспроможності персоналу на рівні підприємства $є$ стан організації праці. Складовими частинами організації праці служать його планування і облік. Планування праці як встановлення пропорцій праці, його продуктивності, чисельності персоналу, фонду заробітної плати для виконання виробничої програми - частина загальної системи, що створює умови для підвищення конкурентноздатності персоналу та підприємства.. Облік праці $є$ необхідною передумовою для встановлення результативності праці, її оплати та матеріального стимулювання.

Особлива роль при формуванні механізму підвищення конкурентоспроможності персоналу належить мотивації трудової діяльності. Існує певна взаємозалежність конкурентоспроможності робочої сили і мотивації: з одного боку, чим більш конкурентоспроможна робоча сила, тим сильніше вона повинна стимулюватися i, навпаки, чим вище ми стимулюємо працівників, тим більш конкурентоспроможними вони повинні бути. Мотивуючи трудову дисципліну, ділову активність персоналу, мотивуючи підвищення кваліфікації і рівня освіти, ставлення до праці і моральними якостями, керівництво тим самим підвищує конкурентоспроможність свого персоналу.

Ще одним елементом механізму підвищення конкурентоспроможності персоналу - $€$ розвиток особистих якостей і компетенцій співробітників підприємства.

Важливе значення для підвищення конкурентоспроможності має саморозвиток людини. Які б зусилля не докладала організація для підвищення рівня конкурентоспроможності, які б кошти вона для цього не витрачала ефрект буде мінімальним, якщо людина не перейметься свідомістю того, що йому це необхідно.

Ефективне підвищення конкурентоспроможності персоналу підприємства забезпечить: швидку адаптація персоналу до соціально-економічних змін середовища та вимогам ринку; зниження плинності кадрів та підвищення прихильності персоналу до своєї організації; підтримка серед працівників основних пріоритетів організаційної культури; зростання прибутку, об'єму випуску та якості продукції, що виробляється; зростання продуктивності та ефективності праці.

Таким чином, конкурентоспроможність персоналу на мікроекономічному рівні передбачає створення сукупності спонукальних важелів, які зумовлять прагнення працівника відповідати певним професійно-кваліфікаційним критеріям і дозволять реалізувати інтереси як працівника, так і роботодавця в умовах ринкової кон'юнктури.

Розглянуті вище елементи механізму формування конкурентоспроможності персоналу допомагають створити ефективний механізм, який враховує умови фуункціонування підприємства, підвищить конкурентні переваги кожного працівника, а також організації в цілому.

\section{Список використаних джерел:}

1. Грішнова, О.А. (2004). Людський капітал. Київ: Знання. 


\section{ПОРІВНЯЛЬНИЙ АНАЛІЗ ДЕРЖАВНОГО БОРГУ ГЕРМАНІЇ ТА УКРАЇНИ}

\section{Штамбург Оксана Олегівна \\ Донецький національний технічний університет \\ УКРАÏHA}

В умовах фінансової глобалізації розвиток міжнародної фрінансової системи характеризується значним збільшенням зовнішнього боргу більшості країн світу. Таке зростання пояснюється сильним десріцитом власних фінансових ресурсів для внутрішніх інвестицій, необхідністю покриття дефріциту державного бюджету, не завжди ефективним використанням позик і кредитів, порушенням боргу та дисбалансом поточних платежів.

В даний час більшість країн світу стикаються з проблемою управління державним боргом. Незважаючи на численні наслідки цього методу фінансування дефіциту бюджету, державні запозичення залишаються найбільш використовуваним методом фінансування витрат.

Рівень навантаження на борг у багатьох країнах, включаючи Україну, є критичним. Це явище вказує на неефективну боргову політику та відсутність оптимальної стратегії управління державним боргом.

Сьогодні в Україні зростає кількість міжнародних відносин з Європейським Союзом. Тож Німеччина була обрана для аналізу як країна-член ЄС. Економічна структура Німеччини характеризується здоровим поєднанням сорери послуг та промисловості. Державний борг Німеччини включає гроші, зібрані фредеральним урядом Німеччини шляхом випуску боргових інструментів.

В останні роки в Україні спостерігається тенденція до збільшення відношення державного боргу до валового внутрішнього продукту (рис.1). У 2015 році відбулося різке зниження валового внутрішнього продукту 3 $179572 \mathrm{млн.} \mathrm{дол.} \mathrm{до} 130571 \mathrm{млн.} \mathrm{дол.} \mathrm{США,} \mathrm{тобто} \mathrm{на} \mathrm{28 \% .} \mathrm{Наступного} \mathrm{року}$ ВВП продовжував знижуватися і становив 90489 млн. дол.

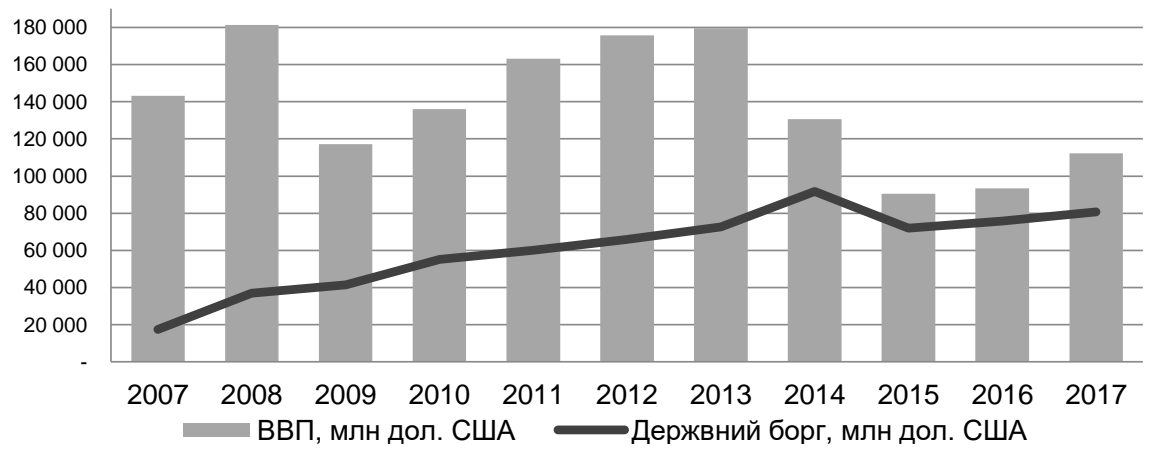

Рис 1. Державний борг та ВВП України за 2007-2017 роки

Джерело: обчислено та побудовано автором за даними [1] 
Серед фракторів, що негативно впливають на ситуацію в економіці, НБУ називає: зниження прибутку від експорту на тлі падіння світових цін на сировину; торговельні обмеження з боку Російської Федерації, девальвація валют країн-торгових партнерів, посилення політичної невизначеність.

Державний борг України у 2017 році зменшився на 9,25\% від його валового внутрішнього продукту з 81,20\% до 71,95\%, тобто на 4907 млн грн.

Державний борг Німеччини у 2013 році становив 72,5 відсотка від річного ВВП, і цей відсоток зменшується у наступних роках. Федеральний уряд має на меті домогтися Маастрихтського ліміту - який диктує, що відношення боргу до ВВП не повинно перевищувати 60 відсотків.

На рис.2 наведено динаміку державного борту та ВВП Німеччини за 20072017 роки.

Загальний борг Німеччини становить приблизно 2,389 трлн. Дол. Також в останні роки спостерігається тенденція до зменшення боргу на одну особу. У 2017 році державний борг на одну особу склав 28864,53 дол. США. Дані показники стосуються всієї країни і включають борги держави, громад, муніципалітетів та соціального страхування. У 2017 році державний борг Німеччини становив приблизно 65 відсотків ВВП.

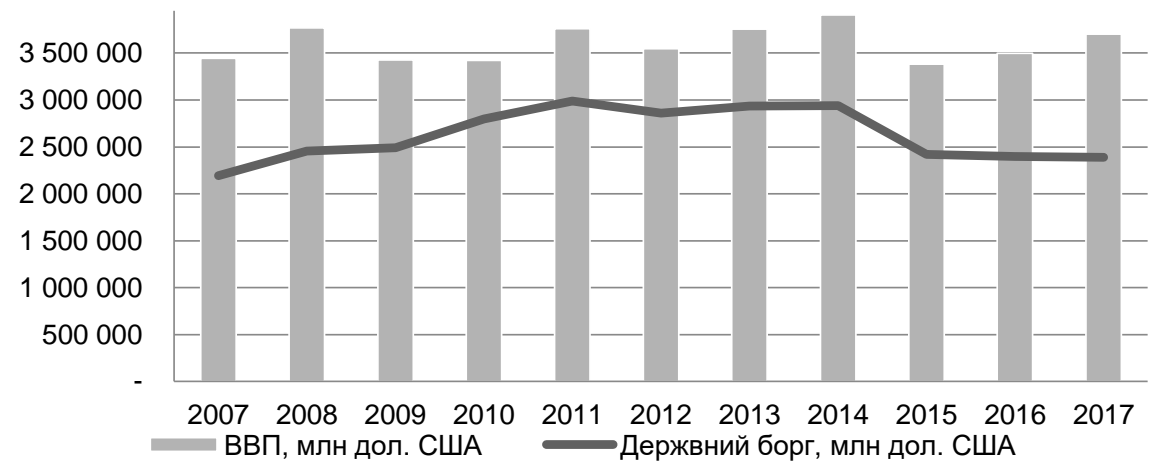

Рис. 2. Державний борг та ВВП Німеччини за 2007-2017 роки Джерело: обчислено та побудовано автором за даними [2]

Підводячи підсумки, враховуючи високий рівень державного боргу, для України критично важливо проводити збалансовану фріскальну (бюджетну) політику. Державний борг по відношенню до розміру ВВП є важливим, але не єдиним показником наявності чи відсутності проблем: як уже згадувалося, деякі розвинені країни, такі як Німеччина, мають дуже високе відношення боргу до ВВП. Тому крім розміру важлива також вартість запозичень, валютна структура державного боргу та графрік платежів по ньому. В останньому випуску Україна стикається з найбільшою проблемою: великими платежами за борги в іноземній валюті з державного бюджету в найближчі роки.

\section{Список використаних джерел:}

1. Ukraine National Debt. Retrieved from https://countryeconomy.com/national-debt/ukraine

2. Germany National Debt. Retrieved from https://countryeconomy.com/national-debt/germany 


\section{ПОРІВНЯЛЬНИЙ АНАЛІЗ МОДЕЛЕЙ БУХГАЛТЕРСЬКОГО ОБЛІКУ, ЗАСТОСОВУВАНИХ В СВІТОВІЙ ПРАКТИЦІ}

Фурман Дар'я Володимирівна

студентка групи ФК-11д (м) обліково фрінансового фракультету Вінницький торговельно-економічний інститут КНТЕУ

НАУКОВИЙ КЕРІВНИК:

Китайчук Тетяна Геннадіївна канд. екон. наук, доцент кафедри обліку та оподаткування Вінницький торговельно-економічний інститут КНТЕУ

УКРАÏHA

Ефективність управління економічними процесами значною мірою залежить від якості, своєчасності та змістовності інформації, якою оперують різноманітні учасники ринкових процесів. Основним формалізованим джерелом інфрормації про фрінансово-майнову позицію окремого підприємства (компанії) та його результатну діяльність $€$ показники, сформульовані системою бухгалтерського обліку і публічно репрезентовані у фрінансовій звітності. Глобалізація, науково-технічний прогрес, зміни в архітектурі фінансово-економічних відносин, на ринках капіталів та інвестицій підвищують (формують істотно нові) вимоги користувачів до інформації, агрегованої системою бухгалтерського обліку та наведеною корпоративною звітністю.

Таким чином, актуальним завданням стає аналіз існуючих систем обліку на рівні класифікаційних ознак, країн, а також створення найбільш чіткої системи, яка об'єднує дані класифікації в схематичною моделі. Така схематична модель дозволяє найбільш широко простежити вплив факторів (економічних, історичних, політичних, соціально-культурних та ін.) на систему обліку в кожній аналізованої країні світу.

Питаннями характеристики типів, моделей бухгалтерського обліку займалися такі наукові діячі: Костіна Д.Ю., Колокольцев О.В., Безверхий К. В., Сидорова М. І., Крістофер Нобес, Роберт Паркер, Геррі Д., Гаррі Карнегі, Крістофер Нейпір, Агім Пітер, Мітчелл Стів, Оверхолзер Хізер, Хі Кінкін, Мотохаші Казуюкі, Джіаніні Мацаюса, Маріан Сакалеук, Джено Беке та ін. Незважаючи на дані дослідження, недостатньо висвітлені питання аналізу існуючих систем обліку на рівні класифрікаційних ознак, питання порівняльної характеристики систем і моделей обліку в розвинених країнах світу, не сформована система, яка б об'єднувала дані класифрікації в схематичну модель.

Система організації обліку в різних країнах прагне до загальної уніфікації та стандартизації. Причиною даних процесів $є$ світова глобалізація, механізм еволюції організації обліку на базі міжнародного обміну досвідом та ідеями, створення найбільш ідеальних бухгалтерських моделей. Важливим моментом в уніфікації організації обліку є поширення Міжнародних стандартів фрінансової звітності (МСФЗ), яке має прогресивний характер. Міжурядові та міжнародні профресійні організації з бухгалтерського обліку та звітності спрямовують свою діяльність (Створюючи МСФЗ та ін.) На гармонізацію принципів обліку та звітності в світовому масштабі. Це створює передумови суттєвого полегшення 
в діловому спілкуванні країн світу. Однак, у зв'язку з тим, що моделі обліку в різних країнах організовуються в різних правових, історичних та соціальнокультурних умовах, існують певні відмінності в орієнтирах і способах організації бухгалтерського обліку в різних країнах світу [1].

Існуючі моделі обліку в межах однієї країни також можуть варіюватися в своєю формою і обраних методах в залежності від форми підприємства, його аспекти та виду діяльності, трудових ресурсів та ін. Тому слід виділити найбільш загальні характеристики, властиві для моделі тієї чи іншої країни.

У світовій практиці не існує країн з абсолютно ідентичними моделями обліку. Вчені-економісти розглядають класифікацію моделей обліку на основі певних критеріїв (при цьому пропонуючи свої аспекти для класифікації), які об'єднують кілька країн в одну модель організації та функціонування бухгалтерського обліку.

Класифікація систем бухгалтерського обліку відбувається за такими критеріями:

- територіально-історичний ознака;

- соціально-економічні умови;

- орієнтація обліку;

- ступінь регламентації обліку;

- тип законодавства і ступеня його впливу на аспекти обліку;

- трактування обліку та ін..

У певної моделі бухгалтерського обліку може існувати той чи інший підхід до вирішення завдань: професіоналізм чи правове регулювання, тривалість або мінливість принципів, оптимізм чи консерватизм, конфіденційність і відкритість [2].

Облікова політика $є$ встановленої сукупністю способів, принципів і методів ведення бухгалтерського обліку. На їі утримання в різних країнах світу впливають такі фактори, як:

- ступінь розвитку фінансового ринку і ринку цінних паперів;

- основні користувачі облікової інформації;

- кількість осіб, що займаються інвестуванням;

- сфера діяльності;

- форма власності;

- участь інвесторів в управлінні бізнесом;

- законодавча база країни;

- ступінь участі підприємства в міжнародному бізнесі [3].

Для порівняльного аналізу моделей обліку в розвинених країнах світу побудуємо (табл.1), в якій відображено якість обліку корпоративного оподаткування.

Таблиця 1

Якість обліку корпоративного оподаткування

\begin{tabular}{|l|c|c|c|c|c|c|c|c|c|c|}
\hline \multicolumn{1}{|c|}{ Показник } & $\begin{array}{c}\text { Південна } \\
\text { Корея }\end{array}$ & Китай & Японія & ОЭСР & США & Германія & $\begin{array}{c}\text { Велико- } \\
\text { британія }\end{array}$ & Швеція & Австралія & Канада \\
\hline $\begin{array}{l}\text { Кількість платежів по } \\
\text { податках на рік }\end{array}$ & 12 & 9 & 14 & 11 & 11 & 9 & 8 & 6 & 11 & 8 \\
\hline $\begin{array}{l}\text { Час, необхідний для } \\
\text { адміністрування } \\
\text { обліковихпроцедур } \\
\text { (годинник) }\end{array}$ & 188 & 61 & 30 & 152,0 & 175 & 218 & 110 & 122 & 105 & 131 \\
\hline $\begin{array}{l}\text { Загальна частка } \\
\text { (\%датків } \\
\text { (\% Від прибутку) }\end{array}$ & 33,2 & 7,8 & 51,3 & 41,1 & 43,9 & 48,8 & 32 & 49,1 & 47,6 & 21,1 \\
\hline
\end{tabular}

[Авторська розробка] 
Чим вище кожен з показників, тим вище рівень прозорості господарської діяльності, більша відповідальність бухгалтерів і керівників, вище рівень захисту інвесторів. Кількість платежів по податках в рік в ОЕСР і США в середньому складають 11 раз в рік, найвищий показник - у Японії (14 разів на рік), і найнижчий - в Швеції (6 разів на рік). Час, який необхідно для адміністративних процедур в Німеччині, Китаї та Японії мають високі показники, оскільки дані процедури автоматизовані, як в одній, так і в іншій країні на високому рівні, це говорить про ретельності перевірки даних процесів. За загальній частці податків в прибутку найбільше значення має Китай $(67,8 \%)$, Японія $(51,3 \%)$.

Ефективне застосування організаційних принципів і методів бухгалтерського обліку притаманне розвинутим країнам світу: Європи (Англія, Франція, Німеччина та ін.), Америки (США, Канада) і Азії (Китаю, Японії, Південної Кореї). Азіатський регіон, завдяки своїй специфріці, характеризується високими темпами розвитку економіки, в останні роки випереджаючими передові країни Європейського Союзу.

Висновки. Таким чином, ми визначили, що моделі бухгалтерського обліку мають різні угруповання, шляхом застосовуваних класифікаторів: територіально-історичний ознака, соціально-економічні умови, орієнтація обліку, ступінь регламентації обліку, тип законодавства і ступеня його впливу на аспекти обліку, трактування обліку та ін. Крім відмінностей між моделями бухгалтерського обліку існують відмінності в межах однієї моделі, які обумовленим різним впливом інших країн по історичним, політичним та ін. аспектам. також необхідно взяти до уваги, що велику роль грають вид діяльності, фрорма власності, ступінь участі підприємства в міжнародному ринку, основні користувачі облікової інформації, кількість осіб, що займаються інвестуванням і ін.

Дані аспекти породжують відмінності мікромодель обліку в межах підприємства, регіону та інших територіальних одиницях. Тому одними 3 найбільш загальних показників для характеристики (моделі) бухгалтерського обліку тієї чи іншої країни служить податкове навантаження, ступінь регламентації законодавчих актів, рівень професіоналізму бухгалтерів і часу проведених на адміністрування бухгалтерських процедур (по податках).

\section{Список використаних джерел:}

1. Голов, С.Ф. (2010). Бухгалтерський облік за міжнароднимим стандартами: приклади та коментарі. Книга: Екаунтінг, 840.

2. Губачова, О.М.(208). Облік у зарубіжних країнах: К: Центр учбової літератури, 432.

3. Ковалев, В.В. (2009). Стандартизация бухгалтерского учета: международный аспект. Бухгалтерский учет. 


\title{
ПРИЧИНИ ТРУДОВОЇ МІГРАЦІЇ МОЛОДІ УКРАЇНИ
}

\author{
Михайлишена К.П. \\ здобувач освітнього ступеня «бакалавр» \\ Вінницький торговельно-економічний інститут КНТЕУ
}

НАУКОВИЙ КЕРІВНИК:

Менчинська О.М.

асистент

Вінницький торговельно-економічний інститут КНТЕУ

УКРАÏHA

В Україні зовнішня трудова міграція сформувалася в умовах високого рівня безробіття, обмеженої можливості офіційного працевлаштування, вимушеної неповної зайнятості з одного боку, також низького рівня оплати праці та, як наслідок, бідності працюючого за наймом населення. Тому в країні спостерігається тенденція щодо розширення міграції задля задоволення потреб у працевлаштуванні та покращення власного добробуту. Отже, дослідження проблем зовнішньої трудової міграції в Україні за умов глобалізації світового господарства є актуальним і практично значущим.

Особливо актуальним є дослідження еміграції молоді, тобто населення у віці від 14 до 35 років, адже сьогодні за кордоном працює велика кількість молодих українців, які залишають Україну в пошуках робочих місць, та власних життєвих перспектив.

Вагомий внесок у розроблення теорії міжнародної трудової міграції, нормативно-правових аспектів регулювання міграційних процесів зробили такі вітчизняні вчені, як І.М. Гнибіденко, С.С. Гриневич, О.В. Заклекта, А.Л. Кравченко, О.А. Малиновська, М.Ю. Приз, І.В. Ховрах, Ю.П. Гуменюк, Н.А. Сирочук.

Метою даного дослідження є визначення основних причин трудової міграції молоді в Україні.

Проблема трудової міграції молоді - одна з найважливіших і в нашій державі. Вона потребує ретельного аналізу науковців та адекватних дій з боку законодавчої та виконавчої влади. Як відомо, в структурі робочої сили України сформувався багатомільйонний контингент осіб, для яких трудоваміграція $є$ основним видом зайнятості й основним джерелом доходів. Тому вирішення цієї проблеми має велике суспільно-політичне та соціальне значення. Трудова міграція молоді впливає на демографічну, соціальну та економічну ситуацію в Україні.

Головними причинами, які змушують українську молодь залишати свої оселі в пошуках кращого життя, є економічні основи. Це, зокрема, низький рівень заробітної плати, значні масштаби безробіття, нестабільність розвитку української економіки. За даними дослідження «Зовнішня трудова міграція населення України», основною причиною виїзду за кордон 6310 мігрантів $є$ низький рівень оплати за відповідну працю в Україні. Серед молодих українців 
$65 \%$ виявляють бажання поїхати за кордон саме для працевлаштування, $14 \%$ - не виключають, що можуть назавжди залишити свою Батьківщину [1].

Істотному зростанню кількості трудових мігрантів сприяло також розширення кордонів $Є С$, що відбулося за рахунок країн Центральної та Східної Європи, й відкриття кордонів між ними. До того ж різке скорочення народжуваності та старіння населення у країнах $€ €$ на тлі розширення виробництва також стимулює зростання міграції української молоді.

Майже половина всіх трудових українськихмігрантів, з перебуває в країнах Європейського Союзу. Найбільші їх часткив Італії (13,4\%), Чехії $(12,8 \%)$, Польщі (7,4\%), Іспанії (3,9\%) та Португалії (3\%) [3]. Такий розподіл трудових мігрантів пояснюється, зокрема, прагненням знайти більш високооплачувану роботу в країнах із спорідненою ментальністю і релігією.

Вагомим чинником міграції молодих студентів-випускників, $€$ неспроможність влаштуватися на роботу за обраним фахом. Хоча і молода кваліфікована робоча сила $є$ найбільш привабливою, проте, коли стоїть вибір перед роботодавцем, обрати випускника з вузу чи старшу людину, яка має досвід роботи, як правило, обирають працівників зі стажем роботи. До того ж, державними органами влади не розроблено програм з підтримки молодих наукових кадрів. Тому більшість студентів, випускаючись з вищих навчальних закладів, не можуть влаштуватись по спеціальності, або їх не влаштовують умови праці та заробітна плата.

Іншим важливим чинником міграційних процесів $є$ економічне зростання у країні перебування трудового мігранта, під час якого збільшується потреба у робочій силі, в тому числі й у низькокваліфікованій. Це, у свою чергу, є додатковим фрактором, який стимулює потік трудових мігрантів до цієї країни. Саме цей процес відбувається нині в Португалії, де економічне зростання та потреба в дешевих робочих руках стимулює масовий в'їзд у цю країну трудових мігрантів, у тому числі з України.

Не останню роль у формуванні масової трудової міграції відіграє байдуже ставлення влади і той фракт, що завдяки останній в Україні зменшується безробіття, знижується соціальна напруженість, зростають валютні надходження за рахунок оподаткування грошових переказів мігрантів своїм родичам. Значна частина трудових мігрантів, зокрема молоді, перебуваючи за кордоном, підвищує свою кваліфрікацію, освоює нові професії, сучасні технології та системи організації виробництва. I ті з них, хто все ж таки повертається на батьківщину, поповнюють лави підприємців і фахівців, чия праця відповідає світовим стандартам; їм легше влаштовуватися на роботу у спільні підприємства [2].

Ще одним фрактором, що сприяє міграції $€$ те, що молода сім'я не має можливості себе забезпечити житлом та гідною заробітною платою, що призводить часто до розпаду сімей. А в Україні так і не розроблено програми по підтримці щойно одружених пар.

Оскільки за кордон виїжджають переважно молоді люди, це не може не позначитися негативно на трудовий потенціал населення. Можна виділити основні негативні наслідки трудової міграції: поперше, виїжджає більша частина трудового потенціалу, в тому числі досвідчені висококваліфіковані 
працівники, які погоджуються на просту роботу і втрачають свій професіоналізм; по-друге, набувають масштабного характеру соціальні наслідки, зокрема: розпадаються молоді сім'ї, де діти залишаються без одного із батьків; мігранти, працюючи нелегально, не отримують належної медичної допомоги; через тяжкі фізичні навантаження і некомфортні побутові умови втрачають власне здоров'я, що призводить до зниження рівня народжуваності, а це призводе до руйнування трудового потенціалу в України.

Таким чином, основними причинами трудової міграції є: національна своєрідність, високий рівень безробіття, низька заробітна плата, неврегульованість соціальних проблем, особливо щодо житла на достатньому рівні для життя, вплив досвіду трудової міграції в сім'ї, сприяння саме молоді у трудовій міграції приймаючими країнами, оскільки молодь $є$ продуктивною робочою силою на ринку праці та рушієм глобалізації світу, а також бажання змінити спосіб життя, бажання одержання коштів для початку самостійного життя, пізнання світу, підвищення професійної та інтелектуальної компетенції, пошук матеріальної незалежності.

\section{Список використаних джерел:}

1. Майданік, І. П. (2018). Українська молодь на ринках праці зарубіжних держав. К.: НАН України.

2. Ромащенко, Т. (2017). Актуальні проблеми сучасної української трудової еміграції. Економіка України, (8), 84-89.

3. Щерба, Г.І. (2019). Основні мотиви зовнішньої трудової міграції молоді України. Молодіжна політика: проблеми та перспективи, (2), 165-168.

\section{РЕГУЛЮВАННЯ ІНФЛЯЦІЙНИХ ПРОЦЕСІВ}

Бевз Яна Юріївна

Вінницький торговельно-економіний інститут Київського національного торговельно-економічного університету

НАУКОВИЙ КЕРІВНИК:

Недбалюк О.П.

канд. екон. наук, доцент

Вінницький торговельно-економіний інститут Київського національного торговельно-економічного університету

УКРӒ̈HA

Інфляція - багатогранний, складний процес, який чітко відображає всі основні проблеми й суперечності економіки. Найбільш наочно вона проявляє себе в систематичному переповненні каналів грошового обігу масою надлишкових грошей, що призводить до їх знецінення та додаткового перерозподілу національного доходу й національного багатства на шкоду більшості населення. Інфляція виникає внаслідок загального підвищення цін на товари, спричиненого будь-якими фракторами. «Будь-який період, протягом 
якого рівень цін підвищився... є період інфляції», - писав американський економіст Л. Клейн. Аналогічних підходів дотримувалися Б. Хансен, Е. Там, Е. Дене та ін. [1].

У більшості розвинутих країн дефріцит державного бюджету становить у середньому 3-4\% ВНП. Дотації у народне господарство та на компенсаційні виплати, пов'язані зі зростанням цін, не повинні перевищувати 10\% загальних бюджетних витрат. Недотримання цих умов може бути причиною інфляції, для подолання якої проводять грошові реформи. Грошові реформи - сутнісні та якісні перетворення у грошовій системі з метою її впорядкування і зміцнення. Пояснюючи причини інфляції за сучасних умов, неокласична, кейнсіанська та соціальна концепції ігнорують дію таких важливих фракторів, як практика монопольного ціноутворення та частка військових затрат у структурі державних. Роль підвищення зарплати в розгортанні інфляційних процесів охарактеризована спрощено й однолінійно (збільшення заробітної плати нібито призводить до автоматичного зростання цін). Насправді підвищення заробітної плати зумовлює передусім зниження прибутку підприємців. Щоб його компенсувати, вони збільшують ціни на товари і послуги. Особлива ситуація склалася в Україні: частка заробітної плати у структурі затрат становить всього 7-8\%, тому зростання заробітної плати або зовсім не позначиться на цінах (зменшиться прибуток багатьох підприємствмонополістів), або спричинить їх мінімальне збільшення. Деякі представники вищих урядових структур України апелюють до аргументів прихильників концепції інфляції затрат виробництва, щоб уникнути відповідальності за нераціональну політику щодо заробітної плати і цін. Сучасній інфляції властива низка характерних особливостей: якщо раніше інфляція мала локальний характер, то зараз - повсюдний і всеосяжний; якщо раніше вона охоплювала певний період, тобто мала періодичний характер, то нині $€$ хронічною. Сучасна інфляяція перебуває під впливом багатьох чинників. Розрізняють монетарні та немонетарні фактори інфляції у сучасній ринковій економіці. На думку економістів-практиків, інфляція спричинюється здебільшого факторами монетарної політики та має моністичний характер, тобто зумовлюється єдиною причиною. Багатофакторні концепції інфляції, як правило, не мають єдиної методологічної основи і зазвичай ґрунтуються на різноманітних припущеннях. Більшість центральних банків, у тому числі Європейський центральний банк, Банк Англії, Національний банк Швейцарії, стабільним вважає рівень інфляції, за якого здорожчання товарів споживання не перевищує 2-3\% [2].

Сьогодні встановлено незаперечний факт, що інфляція не є безмежною. Вона має зовнішні і внутрішні межі, які й намагаються виміряти і встановити економісти як орієнтири. В умовах пікових темпів інфляції доцільною $€$ рестрикційна політика - політика стримування. ІЇ̈ характерні риси: скорочення витрат бюджету та позичкового відсотка, стримування експорту і грошової емісії, підвищення податкових ставок. У кінцевому підсумку зазначені заходи дають скорочення сукупного попиту. Необхідно звернути увагу на те, що суттєво поліпшити ситуацію можна лише за умов комплексного вживання заходів антиінфляційного регулювання. Адже економіку будьякої країни слід розглядати як систему, організм з обмеженою кількістю прямих та 
опосередкованих зв'язків. Механізм дії інфрляційних фракторів залежить від співвідношення багатьох економічних процесів - внутрішніх і зовнішніх. Він неоднорідний на часовому проміжку становлення ринкової економіки в Україні. Також неоднакова активність конкретних інфляційних факторів. Це зумовлено тим, що інфрляція - передусім динамічний процес. У більшості випадків ті негативні процеси, які проглядаються на рівні макроекономіки, $є$ наслідком значних деформацій внутрішніх економічних процесів, як макро-, так і мікроекономічних. Через системний підхід, комплексне оздоровлення фрінансової ситуації, що мають бути узгоджені з конкретними національними особливостями, конкретними змінами процесів у кожній ланці економічної системи країни, досягають позитивного довготермінового ефректу. Інакше, якщо засоби щодо оздоровлення економічної ситуації використовуються частково, то результат буде також тимчасовий. Заходи з оздоровлення фінансової ситуації в Україні можуть дати позитивні результати лише за умов початкового, обов'язкового і суттєвого оздоровлення фрінансів, базової ланки економіки - фінансів підприємств та організацій, ефективного стимулювання ділової активності та підприємництва [3].

Управління інфляцією $€$ найважливішою проблемою грошово-кредит-

ної і загалом економічної політики. Необхідно враховувати при цьому багатоскладовий, багатофракторний характер інфрляції. В її основі лежать не тільки монетарні, а й інші чинники. За всієї значущості скорочення державних витрат, поступового стиснення грошової емісії потрібне вживання широкого комплексу антиінфляційних заходів. Серед них - стабілізація і стимулювання виробництва, вдосконалення податкової системи, створення ринкової інфраструктури, підвищення відповідальності підприємств за результати господарської діяльності, зміна обмінного курсу грошової одиниці, регулювання цін і прибутків. Нормалізація грошового обігу і протидія інфляції вимагають вивірених, гнучких рішень, що послідовно і цілеспрямовано повинні втілюватися в життя [4].

\section{Список використаних джерел:}

1. Алексєєв, І. В. \& Колісник, М. К. (2009). Гроші та кредит. Киї: Знання.

2. Гриценко, А. А., Кричевська, Т. О., \& Петрик, О. І. (2011). Інститут таргетування інфляції: зарубіжний досвід і перспективи запровадження в Україні. Київ.

3. Круш, П. В. \& Клименко, О. В. (2010). Інфлляція: суть, форма та її оцінка. Київ : Центр учбової літератури.

4. Марцин, В. С. (2013). Деякі підходи до регулювання інфрляційних процесів на сучасному етапі розвитку економіки. Київ. 


\section{РОЛЬ ФІНАНСОВИХ МЕНЕДЖЕРІВ В СУЧАСНИХ УМОВАХ ВЕДЕННЯ БІЗНЕСУ}

Романчук Руслан Анатолійович
здобувач вищої освіти фракультету економіки, менеджменту та права
Вінницький торговельно-економічний інститут КНTEУ

НАУКОВИЙ КЕРІВНИК:

Демченко Оксана Петрівна

канд. екон. наук, доцент

Вінницький торговельно-економічний інститут КНТЕУ

УКPAÏHA

Невід'ємною складовою соціально орієнтованої ринкової економіки є ефективно функціонуюча ланка фінансової системи - фінанси підприємств. Формування та забезпечення конкурентоспроможності української економіки та її ефрективне інтегрування у світове економічне співтовариство неможливе без ефективного фінансового управління господарською діяльністю підприємств.

Перш за все, варто відзначити, що ключова мета фінансового менеджменту відповідає цільовій функції господарюючого суб'єкта максимізація ринкової вартості підприємства в результаті зростання прибутку і її реінвестування в бізнес при допустимому рівні ризику. Однак не варто забувати, що поряд з головною існують і інші цілі фрінансового менеджменту, такі як максимізація прибутку компанії, забезпечення сталого темпу зростання розвитку підприємства, підтримка фрінансової стійкості і платоспроможності, підвищення темпів зростання підприємства, мінімізація витрат і багато інших. Реалізація представлених цілей покладено на одних з найважливіших фігур компанії - фінансових директорів, роль яких неухильно зростає.

Дослідженням проблем фінансового менеджменту займались такі вітчизняні і зарубіжні учені, як І.А. Бланк, Л.Д. Буряк, В.М. Власов, О.Є. Ґудзь, М.Я. Дем'яненко А.М. Поддєрьогін, Г.Б. Поляк, В.М. Родіонова, А.Д. Шеремет, Сигел Джоел та інші. Але з огляду літературних джерел помітно, що існує ціла низка ще не розв'язаних проблем 3 теорії та практики фрінансового менеджменту діяльності підприємств, які ще недостатньо висвітлені i потребують подальшого вивчення.

В даний час в Україні підвищується попит на фрахівців в області фрінансів фінансових директорів, фрінансових менеджерів, фрінансових керуючих. Дані поняття в літературі часто вживаються як синоніми, що обумовлено тим, що на законодавчому рівні поки не проведена регламентація трудових функцій фахівців в області фінансів.

Роль фінансових фрахівців не завжди була однаковою. Першу половину 20 століття фінансові керівники в основному займалися залученням необхідних ресурсів для розвитку діяльності компанії і організацією їх ефеективного використання. У 1950-ті роки в фінансовому аналізі поширення концепції приведеної вартості змусило фінансових керівників розширити сферу своїх обов'язків, і серед головних з'явилася така функція як відбір інвестиційних проектів компанії в довгостроковому періоді. 
Робота фінансових директорів на будь-якому підприємстві в сучасних умовах спрямована на вирішення фінансових проблем, які можуть виникнути на різних стадіях фрункціонування підприємства.

Серед основних проблем можна виділити:

- обмеженість фрінансових ресурсів, необхідних для розвитку;

- зниження платоспроможності та фрінансової стійкості підприємства в зв'язку з тим, що відбувається розрив між часом отримання коштів та проведенням необхідних платежів;

- низький рівень економічної ефективності діяльності.

У зв'язку з цим можна виділити основне призначення фінансового топменеджера - підвищення економічної ефективності діяльності через прийняття фінансових рішень, які пов'язані, головним чином, з інвестуванням, фрінансуванням і ефективним управлінням активами.

У класифрікаційному довіднику посад керівників, фрахівців та інших службовців представлений широкий набір посадових обов'язків фінансових директорів [1]. Серед них слід виділити роботу даних фахівців, пов'язану з:

- визначенням фінансової політики організації;

- керівництвом роботою 3 управління фрінансами 3 урахуванням поставлених стратегічних цілей і перспектив розвитку організації;

- організацією залучення як фінансових, так і реальних інвестицій та їх оцінка;

- визначенням основних джерел фрінансування діяльності з урахуванням мінливої ринкової кон'юнктури;

- здійсненням аналізу і оцінки фрінансових ризиків;

- раціональним розміщенням тимчасово вільних грошових коштів з метою збільшення прибутку організації;

- керівництвом складання поточних і перспективних фрінансових планів і різних бюджетів (продажів, витрат на виробництво і продаж продукції, грошових коштів);

- здійсненням постійного контролю за станом, рухом і цільовим використанням фінансових коштів, і багато інших [2].

У сучасних ринкових умовах для фінансового директора важливим i затребуваним $\epsilon$ також впровадження міжнародних стандартів фрінансової звітності, а також уміння залучати позикові кошти на вигідних для підприємства умовах, володіти різними фрінансовими інструментами (овердрафт, похідні цінні папери, такі як ф'ючерси).

Отже, сучасний фрінансовий менеджер повинен володіти великими знаннями в галузі фрінансів, кредиту і фінансового менеджменту; оцінки інвестицій як реальних, так і фінансових, бухгалтерського обліку. Він зобов'язаний знати чинне законодавство країни в області фрінансової, кредитної, біржової, валютної та інвестиційної діяльності, порядок здійснення операцій на фрінансовому ринку, основи економіки господарюючого суб'єкта, зовнішньоекономічної діяльності, оподаткування, а також методику i методологію економічного аналізу.

Слід відзначити той фракт, що крайня мінливість зовнішніх умов господарювання підприємств, вимагає від фрінансового директора гнучкості, своєчасності прийнятих фінансових рішень. Інакше підприємству важко буде вижити в сучасних динамічних умовах.

При аналізі місця фрінансового директора в зарубіжній і вітчизняній компаніях було помічено наступне. Про чіткому розподілі фрункцій між 
фінансовими працівниками можна говорити стосовно іноземних компаній або закордонних представництв. Так, наприклад, в іноземних компаніях прийнято, що керівництво всією фрінансовою роботою здійснює віце-президент 3 фінансів, в підпорядкуванні якого знаходяться керівник фінансового відділу та головний бухгалтер. Вони в свою чергу здійснюють керівництво фрінансовими менеджерами, економістами, аналітиками, бухгалтерами та іншими фахівцями в галузі фрінансів та бухгалтерського обліку.

На багатьох українських промислових підприємствах чіткого розуміння структури фрінансового менеджменту поки немає. Тому на невеликому підприємстві працівник, який відповідає за фінансову роботу, довільно (як правило, за рішенням директора підприємства) називається або фрінансовий директор, або фінансовий менеджер.

Так, проведений автором аналіз запропонованих в даний час вакансій фрінансових фрахівців в різних містах показав, що під фрінансовим менеджером розуміють помічника фрінансового директора - особа, відповідальна за проведення заходів з контролю роботи бухгалтерії і бере участь в підготовці фінансової звітності. В іншій компанії потрібен фрінансовий менеджер, обов'язки якого зводяться до проведення фрінансового обліку, роботі з рухом грошових коштів, планування фінансових документів і звітів [3].

Цікавим фрактом $€$ найбільш популярний вік фінансових директорів. За підсумками міжнародного дослідження, проведеного рекрутингової компанією Michael Page International, саме в Україні фрінансові директори компаній молодше, ніж у будь-якій іншій країні: кожен десятий зайняв цей пост у віці до 30 років.

Так, більшість американців - учасників дослідження Michael Page «Глобальний барометр СFO 2017», досягають посади головного фінансиста в компанії лише до 40-44 років. А в середньому по світу цей показник 30-39 років (понад $60 \%$ стали фінансовими директорами в такому віці, а кожен десятий був молодше 30 ).

Однак слід зазначити, що все-таки саме з роками приходить досвід управління фінансів, професійна зрілість і, що не менш важливо, людська, i тому крупні, процвітаючі, особливо міжнародні, компанії вважають за краще фінансових директорів зі стажем роботи від 10 до 15 років, що цілком зрозуміло.

Таким чином, фрінансовий директор $€$ одним 3 вищих представників компанії, відповідальним за управління фрінансовими потоками бізнесу, за фінансове планування і звітність та багато іншого. Хоча формально статус фрінансового директора визначено загальним кваліфікаційним довідником, але фрактично на кожному підприємстві існують свої конкретні вимоги до фінансового директора: в залежності від розмірів, структури підприємства, галузі його діяльності, стратегії та перспективи розвитку компанії.

\section{Список використаних джерел:}

1. Брігхем, Е. Ф. (2012). Фінансовий менеджмент. Санкт-Петербург.

2. Вахович, Дж. М. (2014). Основи фінансового менеджмента. Санкт-Петербург: Вильямс.

3. Мацибора, В. І., Збарський, В. К. \& Мацибора, Т. В. (2011). Економіка підприємства. Київ: Каравела. 


\title{
СВІТОВИЙ ДОСВІД ФІНАНСОВОЇ ПІДТРИМКИ СУБ'ЄКТІВ МАЛОГО БІЗНЕСУ В КОНТЕКСТІ РОЗВИТКУ КОНКУРЕНТОСПРОМОЖНОСТІ ТРУДОВОГО ПОТЕНЦІАЛУ РЕГІОНУ
}

\begin{abstract}
Мазуренко Наталія Володимирівна
студентка відділення фінансів, обліку та маркетингу

Торговельно-економічний коледж

Київського національного торговельно-економічного університету

Серікова Оліга Миколаївна

канд. екон. наук, доцент

Торговельно-економічний коледж

Київського національного торговельно-економічного університету
\end{abstract}

УКРӒ̈HA

Постановка проблеми. Світовий досвід і практика господарювання показують, що найважливішою ознакою ринкової економіки $є$ існування i взаємодія багатьох великих, середніх і малих підприємств, їх оптимальне співвідношення. Найбільш динамічним елементом структури народного господарства, що постійно змінюється, є малий бізнес.

Набутий власний досвід, позитивні результати розвитку малого підприємства в країнах, які пройшли етап реформування економічних систем, свідчать про те, що мале підприємництво $€$ одним із засобів усунення диспропорцій на окремих товарних ринках, створення додаткових робочих місць і скорочення безробіття, активізації інноваційних процесів, розвитку конкуренції, швидкого насичення ринку товарами та послугами. А малі підприємства, за певних умов і при підтримці з боку держави - тенденційно інноваційні, гнучкі і витратоефективні, мають підприємницький досвід і достатній професійний рівень. Проте, складна політична ситуація, падіння попиту на продукцію, високі ставки оподаткування, несприятливий інвестиційний клімат, обмеженість доступу до джерел фінансування, збільшення тиску державних органів на діяльність малих та середніх підприємств значно перешкоджають їх розвитку.

Аналіз останніх досліджень та публікацій. Наразі досить широке коло науковців присвячують публікації аналізу державної регуляторної політики в сфері розвитку малого та середнього бізнесу і формуванню напрямків її удосконалення. Серед них такі вчені як: В. Дикань, О. Дикань, Ю. Кіндзерський, Г. Поліщук, А. Толстова, О. Шраменко, О. Якушева та ін. Більшість дослідників наголошують на важливості державного регулювання діяльності суб'єктів малого та середнього бізнесу. У той час як деякі з науковців наполягають на доцільності використання механізму дерегуляції розвитку суб'єктів малого та середнього підприємства. Тому важливим питанням $є$ вивчення світового досвіду державної політики в сфері розвитку суб'єктів малого та середнього бізнесу з метою визначення оптимального рівня співвідношення інструментів державного регулювання та лібералізації даного сектору економіки.

Об'єктом дослідження $є$ фінансова політика держави як інструмент підтримки розвитку малого підприємництва. 
Предметом дослідження є теоретичні та практичні питання формування та реалізації державної політики щодо фрінансової підтримки розвитку малого підприємництва.

Виклад основного матеріалу. На сучасному етапі розвитку соціальнотрудових відносин для багатьох країн характерною є тенденція, відповідно до якої все більша частка трудового потенціалу самореалізовується через підприємництво, тобто власний бізнес, оскільки він розкриває простір для розвитку людського потенціалу, сприяє підвищенню ефрективності використання людських ресурсів, створенню нових робочих місць та формуванню конкурентного середовища на ринку робочої сили. Із цього слідує, що рівень конкурентоспроможності соціально-трудового потенціалу безпосередньо детермінується розвитком підприємницької діяльності населення та його здатністю до продукування інноваційних ідей. 3 цієї причини проблемам фінансової підтримки підприємницької та інноваційної активності населення останнім часом приділяється значна увага з боку науковців.

Слід зазначити, що комплекс заходів політики у сфері управління соціально-трудовим потенціалом, як правило, спрямований на зменшення рівня офріційно зареєстрованого безробіття, і часто саме цими заходами даний напрямок політики і вичерпується. Однак саме тільки зниження кількості зареєстрованих безробітних ще не свідчить про зростання ефрективності використання наявних людських ресурсів та про високий рівень конкурентоспроможності соціально-трудового потенціалу. Тому, на нашу думку, пріоритетними в соціально-економічній політиці центральних та місцевих органів влади мають бути не стільки заходи, спрямовані на забезпечення економічно активного населення будь-якими робочими місцями, скільки створення умов, які б забезпечували можливість для максимально ефективної реалізації носіями трудового потенціалу своїх трудових здібностей.

Регіональні інститути розвитку конкурентоспроможності соціальнотрудового потенціалу функціонують як система, де поряд з функціональними інституціями важлива роль відводиться спеціальним, діяльність яких спрямована на розвиток творчих здібностей людей, їх швидку адаптацію до діяльності в мінливому ринковому середовищі.

Спеціалізовані регіональні інститути розвитку конкурентоспроможності соціальнотрудового потенціалу включають інфрраструктуру підтримки малого бізнесу (бізнес-центри, бізнес-інкубатори, агентства регіонального розвитку, спеціалізовані державні та недержавні інноваційні фонди, лізингові центри, інформаційно-консультаційні установи); освітньо-наукові заклади та фонди, центри підготовки та перепідготовки кадрів.

Важливе місце також займає законодавство, інформація, стратегічні та програмні документи, інституційне середовище, співпраця між заінтересованими сторонами, державно-приватний діалог, а також охоплює питання сприятливого бізнес-клімату, можливості оцінки впливу зміни законодавства на провадження підприємницької діяльності, спрощений порядок реєстрації та закриття підприємств, отримання ліцензій та дозволів, розширення доступу малого і середнього підприємництва до публічних закупівель.

3 метою заохочення підприємців до створення нових робочих місць доцільним було б створення спеціальних фондів, призначених для фрінансової 
підтримки тих власників малого бізнесу, які здійснюють працевлаштування найманих працівників. Такий захід дав би змогу частково компенсувати роботодавцям витрати на утримання найманих працівників i, водночас, створив би передумови для збільшення обсягів виробництва продукції чи надання послуг, що, в свою чергу, послужило б поштовхом для подальшого зростання сектору малого бізнесу та чисельності зайнятих у даній сфері.

Одним 3 найбільш яскравих та результативних прикладів розвитку підприємництва та самостійної зайнятості населення можна вважати досвід Великобританії, а саме економічну політику, здійснювану на початку 80-их років минулого століття прем'єр- міністром М.Тетчер. Одною з ключових проблем економіки Великобританії на той час була необхідність структурної перебудови народного господарства країни, скорочення питомої ваги підприємств державної форми власності та частки великих промислових підприємств у структурі народного господарства. Такі структурні зміни супроводжувалися суттєвим зростанням рівня безробіття населення внаслідок закриття та ліквідації збиткових підприємств насамперед у вугільній промисловості. 3 цієї причини перед урядом Великобританії постало завдання реформування не тільки структури народного господарства, а й сфери зайнятості населення, яка на той час була неефективною та не забезпечувала необхідні передумови для економічного прогресу.

Для реалізації даної мети урядом М.Тетчер було розроблено програму підтримки малого підприємництва як альтернативної форми зайнятості, яка водночас формує передумови для створення нових робочих місць. Серед основних заходів даної програми, у першу чергу, потрібно назвати реформування податкової системи з метою зменшення податкового тиску на суб'єктів підприємницької діяльності, а також створення зон вільного підприємництва, в межах яких застосовувалося пільгове оподаткування та кредитування.

Ще одним важливим заходом підтримки малого бізнесу Великобританії стало створення системи організацій ( таких як “Служба малих фрірм”, “Центри праці" ), які надавали консультаційні послуги безробітним, які виявили бажання започаткувати власний бізнес. Крім того, на державному рівні було розроблено низку спеціалізованих програм підтримки малого підприємництва, в основі яких лежав диференційований підхід до різних категорій підприємців; тобто особи, що організовували власну справу, поділялися за віком, за рівнем освіти та за належністю до певних професійних груп. Особлива увага з боку органів державної влади приділялася сприянню та створенню умов для розвитку молодіжного підприємництва, зокрема успішно реалізовувалася на практиці програма "Молоді підприємці".

Важливим елементом механізму стимулювання підприємництва у Великобританії стало кредитування підприємств малого бізнесу, яке здійснювалося спеціалізованими банківськими установами під гарантування органів місцевої влади. Ще одним заходом, що сприяв активізації підприємницької діяльності, стала виплата безробітним одноразової допомоги для започаткування власної справи.

3 метою зниження рівня безробіття, реформування сфери зайнятості та створення передумов для підвищення конкурентоспроможності соціальнотрудового потенціалу урядом Великобританії було вжито ряд заходів, спрямованих на забезпечення більш високого рівня мобільності робочої сили. 
Наслідком застосування даних заходів стало створення масштабної програми профресійної підготовки та перепідготовки кадрів, а також широкої мережі урядових та комерційних організацій, які надавали послуги з підвищення кваліфікації особам, освітньо-кваліфікаційні характеристики яких не відповідали існуючим на той час потребам ринку праці Великобританії.

Крім того, результативним та економічно доцільним заходом стало розширення сфери неповної зайнятості, що дало змогу підвищити рівень економічної активності населення, тобто збільшити кількість осіб, залучених до трудової діяльності, а також створити необхідні передумови для ефрективного поєднання процесів отримання освіти чи підвищення кваліфрікації з участю у виробництві.

Наслідком економічної політики уряду М.Тетчер стало якісне рефрормування сорери зайнятості населення, зниження рівня безробіття, суттєве зростання як кількості малих та середніх підприємств, так і їх ролі в народному господарстві, підвищення якості соціальних ресурсів внаслідок зростання рівня їх освіченості та розвитку професійної мобільності.

Практика надання безробітним одноразової фінансової допомоги для започаткування підприємницької діяльності в подальшому набула поширення не тільки у Великобританії, а й в інших економічно розвинутих країнах. Цільове використання допомоги для започаткування власної справи контролюється. Наприклад, у Франції термін діяльності нового підприємства повинен бути не меншим, ніж 341 день; інакше учасник програми повинен повернути суму допомоги, розмір якої встановлюється, виходячи із розміру допомоги по безробіттю [4].

Яскравим прикладом ефективного використання стимулюючої державної політики щодо малих та середніх підприємств є післявоєнна Німеччина, яка досягла значних успіхів у соціально-економічному розвитку за короткий період завдяки тому, що основним фактором реалізації реформ була рушійна сила енергійного розвитку малого та середнього підприємництва.

До основних програм, спрямованих на розвиток малого та середнього підприємництва в Німеччині відносяться "Концепція розвитку науковотехнічної політики по відношенню до підприємств малого і середнього підприємництва" та "Стимулювання заощаджень для відкриття власного бізнесу". За допомогою першої - здійснюється забезпечення фінансування малого підприємництва країни, друга - сприяє відкриттю власної справи із застосуванням проектів "start-up".

Європейські країни дуже активно підтримують розвиток експортного потенціалу свого малого бізнесу. Діють ефективні системи гарантій експортних поставок до Німеччини.

Найбільшу частину малих підприємств в Іспанії становить сільське господарство - до 70\%, інші галузі, такі як будівництво, промисловість, суднобудування складають близько 25-30 відсотків.

В Іспанії існує безліч програм, спрямованих на підтримку і розвиток малого підприємництва та діє велика кількість організацій, які захищають інтереси малого підприємництва.

До позитивних сторін розвитку малого підприємництва в Іспанії слід зазначити низький рівень бюрократії. Для реєстрації малого підприємства і отримання ліцензії підприємці витрачають не більше 24 годин. Такі ж умови 
поширюються і на не резидентів країни. В результаті, іноземні громадяни беруть участь у розвитку малого підприємництва країни.

Уряд Іспанії сприяє розвитку наукомістких галузей і наукових досягнень. Програми розвитку малого підприємництва ґрунтуються на європейських програмах, що розповсюджуються на багато країн Європи, такі як Німеччина, Франція, Великобританія та інші.

Велика увага приділяється тим суб'єктам малого підприємництва, які беруть активну участь в соціальній політиці країни шляхом створення додаткових робочих місць для соціально незахищених громадян, таких як студенти, жінки, іммігранти і т.д., а також сприяють розвитку регіонів з низькими економічними показниками.

В інших країнах підтримка малого бізнесу більшою мірою здійснювалася за допомогою пільгового кредитування безробітних, що виявили бажання займатися підприємництвом. Наприклад, на початку 1990-их років у Польщі в рамках реструктуризації економіки на ринкових засадах діяли Програма розвитку приватного сектора та Програма підтримки малих і середніх підприємств, які передбачали надання безробітним пільгових кредитів для здійснення підприємницької діяльності на конкурсній основі. Для отримання кредиту безробітні проходили співбесіду та заповняли анкети, в яких давали відповіді на запитання щодо плану розвитку майбутнього підприємства. Крім того, обов'язковою умовою включення до названих програм була попередня професійна підготовка безробітних, яка здійснювалася місцевими центрами зайнятості.

Висновки з проведеного дослідження. Таким чином, досвід розвинутих країн свідчить, що найбільш перспективним напрямком підвищення конкурентоспроможності соціально-трудового потенціалу $є$ створення умов для ведення підприємницької діяльності, оскільки саме підприємництво сприяє формуванню інноваційного типу мислення, підвищенню ініціативності, ділових якостей населення, тобто тих якісних характеристик, які $€$ головними чинниками високого рівня конкурентоспроможності трудового потенціалу.

Запровадження механізмів фінансової підтримки підприємницької активності населення вимагає постійного контролю за дотриманням цільового призначення та ефективності використання отримуваних коштів. 3 цією метою необхідно здійснювати постійний моніторинг діяльності суб'єктів малого бізнесу, що отримують фрінансову допомогу, в протилежному випадку може мати місце нецільове використання коштів.

\section{Список використаних джерел:}

1. Варналій, 3.С. (2014). Мале підприємництво України як чинник регіонального розвитку : стан та перспективи. Харків: Фоліо.

2. Галан, Н.І. (2007). Державна підтримка малого та середнього бізнесу : досвід зарубіжних країн. Донецьк : ДНУ. 2007.

3. Сизоненко, В. (2015). Інституціональні та функціональні основи розвитку підприємництва. Харків: Ранок.

4. Тілікіна, Н.В. (2008) Концептуальні підходи до дослідження мобільності робочої сили. Київ: Основа. 


\section{СИСТЕМА ДЕРЖАВНИХ ЗАКУПІВЕЛЬ ТА Ї̈ ФУНКЦІОНУВАННЯ}

Бевз Яна Юріївна

Вінницький торговельно-економіний інститут Київського національного торговельно-економічного університету

НАУКОВИЙ КЕРІВНИК:

Даценко Г.В.

канд. е. наук, доцент

Вінницький торговельно-економіний інститут

Київського національного торговельно-економічного університету

УКPAÏHA

Головна мета функціонування системи державних закупівель визначається необхідністю забезпечення ефективного використання бюджетних коштів при розвитку конкуренції, прозорості та відкритості організації процесу закупівель. Слід зазначити, що це лише одне із завдань системи державних закупівель, через рівень вирішення якого може оцінюватися ефективність системи.

Зазначимо, що проводячи дослідження, автор не буде торкатися загальної теорії поняття системи, а розгляне проблему ефективності функціонування системи через категорію мети. Тому ми обмежимось визначенням лише основних елементів системи державних закупівель з фіксацією цілей їх фрункціонування для подальшої оцінки рівня досягнення цих цілей [3].

Для проведення дослідження визначимо найважливіші елементи системи державних закупівель:

- законодавче забезпечення організації державних закупівель встановлення прозорих та зрозумілих правил здійснення закупівель;

- створення відповідних інституцій, у тому числі державних - координація та надання консультативних послуг у сфрері державних закупівель;

- інфрормаційне забезпечення - широке інформування замовників та потенційних учасників процедур закупівлі;

- здійснення контролю за дотриманням розпорядниками державних коштів законодавства щодо державних закупівель - забезпечення дотримання законодавства, попередження порушень, притягнення до відповідальності;

- навчання, розробка освітніх програм - підготовка і підвищення кваліфікації фрахівців, що безпосередньо займаються закупівлями товарів, робіт і послуг в організаціях-замовниках [4].

Законодавче забезпечення організації процесу державних закупівель характеризується постійними змінами. Так, з часу введення в дію Закону України "Про закупівлю товарів робіт і послуг за державні кошти", а саме, з 2000 року, зміни вносились 10 разів, при цьому протягом 2-х останніх років - 6 разів. А три останні законодавчі зміни внесли більше 374 змін до нормативної бази, з яких 175 набрали чинності з 12 березня 2007 року.

Аналіз попередніх законодавчих змін досліджувався автором, тому вважаємо за доцільне зосередити увагу на причинно-наслідковому зв'язку законодавчих змін та тенденцій у сфері державних закупівель і в подальшому 
акцентувати увагу на останніх законодавчих змінах та прогнозній оцінці їх впливу на систему державних закупівель.

Аналіз ситуації у сфері державних закупівель свідчить про значні негативні наслідки, які виникли у зв'язку із суттєвими законодавчими змінами і призвели до практичного знищення державного управління сферою закупівель за бюджетні кошти. Відбулося законодавче закріплення функцій органу виконавчої влади за однією громадською організацією, ліквідовано єдине інформаційне джерело про державні закупівлі. Законодавча вимога щодо оприлюднення інформації в інформаційних системах, без створення відповідних умов для розвитку конкуренції у цій сфері, призвела до можливості встановлення монопольної ренти, шляхом замикання на приватну комерційну структуру процесу організації проведення процедур закупівель не лише бюджетними закладами, а й державними, казенними, комунальними підприємствами. Це призводить до значних додаткових фінансових витрат та погіршує їх конкурентоспроможність.

Аналізуючи кількісну та вартісну характеристику стану закупівель у Вінницькій області за 2006 рік, слід відзначити скорочення загальної кількості процедур закупівель майже на 30\% при одночасному збільшенні асигнувань на закупівлі в 1,7 разів. При цьому відмічається тенденція щодо зростання закупівель за процедурою відкриті торги. Загальна кількість закупівель за процедурою відкриті торги зросла в 2,3 рази, питома вага якої в загальній кількості торгів склала майже $20 \%$, проти $6 \%$ у 2005 році.

Однак, при зростанні загальної кількості відкритих торгів, обсяг закупівель в середньому за однією процедурою майже не змінився, а обсяг закупівель в середньому за однією процедурою запиту цінових котирувань зріс майже в 2 рази, за процедурою закупівлі у одного виконавця - зріс в 3,2 рази, що свідчить про досить значну частину коштів (33\% від загального обсягу коштів), які витрачаються на закупівлі за спрощеною процедурою закупівель - запит цінових котирувань та неконкурентною процедурою - у одного виконавця.

Особливо слід наголосити на негативній тенденції щодо зниження рівня конкуренції у сфері державних закупівель на регіональному рівні. При загальному скороченні кількість учасників, які приймали участь у всіх торгах 3 2,7 до 2,6 одиниць, значно скоротилась (на $30 \%$ ) кількість учасників, які приймали участь у процедурі відкритих торгів (з 3,35 до 2,4 одиниць). На думку автора, ця негативна тенденція обумовлена обов'язковим встановленням плати за тендерну документацію, встановлення вимоги щодо надання тендерного забезпечення і $€$ особливо загрозливою для організації торгів в поточному році через запровадження вимоги щодо проведення торгів за умови розгляду не менше 3-х пропозицій учасників торгів [1].

Щодо останніх змін, які внесено до Закону України "Про закупівлю товарів, робіт та послуг за державні кошти" (далі Закону) зазначимо наступне.

Зменшено нижню межу застосування Закону - для закупівлі товарів, послуг вона становить або перевищує 20 тисяч гривень, а для робіт - 50 тисяч гривень (було відповідно 30 і 300 тис. грн.).

Розширено 39 до 26 перелік предметів закупівлі, на які дія Закону не поширюється.

Позитивно оцінюються зміни щодо визначення умов проведення закупівлі для поточних потреб окремих предметів закупівлі до проведення торгів. 
30 - Problems and prospects of implementation of innovative research results $\bullet$ Volume 2

Зменшено нижню порогову межу застосування процедури редукціон для товарів, робіт та послуг з 100 до 50 тис. грн.

Зменшено верхню порогову межу застосування процедури запиту цінових котирувань. Замовник може здійснювати закупівлю шляхом застосування процедури запиту цінових пропозицій (котирувань) щодо товарів, робіт і послуг, для яких існує постійно діючий ринок, та за умови, що вартість предмета закупівлі не перевищує 50 тисяч гривень (було 100,0 тис. грн. у разі закупівлі товарів і послуг та 200 тисяч гривень - робіт).

Ускладнюється проведення процедури запиту цінових котирувань через встановлення вимоги щодо публікації оголошення. Для отримання цінових пропозицій замовник публікує оголошення щодо запиту цінових пропозицій (котирувань) та одночасно надсилає запит щодо цінових пропозицій (котирувань) не менше ніж трьом учасникам та розміщує його в інфрормаційних системах у мережі Інтернет. Строк подання учасниками цінових пропозицій встановлюється замовником, але не може бути меншим ніж п'ять робочих днів 3 дня опублікування оголошення. Враховуючи існуючі проблеми із оприлюдненням інформації про торги, зазначені зміни призведуть до збільшення тривалості проведення процедури мінімум на 15 днів [2].

\section{Список використаних джерел:}

1. Дмитренко, Г. В. (2011). Організація і здійснення державного фрінансового контролю в Україні. Київ: Наук. думка.

2. Мартинович, Д. Е. (2016). Аналіз ефективності публічних закупівель як інструмент державної допомоги. Київ: Наук. думка.

3. З.Ткаченко, Н. Б. \& Уманцій, Ю. М. (2009). Макроекономічні аспекти державних закупівель. Київ: Наук. думка.

\section{СУЧАСНИЙ СТАН ФІНАНСОВОГО РИНКУ УКРАЇНИ}

\section{Штамбург Оксана Олегівна \\ Донецький національний технічний університет}

УKPÄ̈HA

Упродовж останніх років фрінансовий ринок України розвивається досить нерівномірно, демонструючи як позитивні, так і негативні тенденції практично у всіх його сегментах. Це зумовлено, насамперед, впливом сучасної фінансової кризи та низкою специфічних проблем, що мають місце в кожному із його сегментів [1].

Фінансовий ринок - це відкрита економічна система, яка представляє собою сукупність економічних відносин та інститутів, пов'язаних 3 перерозподілом капіталу [2]. У всіх сегмента фрінансового ринку діють посередники, що оперують різноманітними фінансовими інструментами та виконують широкий набір функцій з обслуговування та управління всіма економічними процесами. Товаром на фрінансовому ринку виступають гроші, надані в тимчасове користування, у формі позик під зобов'язання або назавжди, під акції [3]. 
Призначення фінансового ринку полягає в забезпеченні підприємствам належних умов для залучення необхідних коштів і продажу тимчасово вільних ресурсів. Фінансовий ринок має суттєвий вплив для розвитку усіх секторів економіки нашої держави, тому питання проблеми розвитку фінансового ринку в Україні є дуже актуальним [4].

Сьогодні розвиток фрінансового сектору в Україні визначається Комплексною програмою розвитку фінансового сектору України до 2020 року, Угодою про співробітництво між Україною та $€ С$, Меморандумом про економічну та фінансову політику та ін. На жаль, прописані там заходи мають переважно лише технічний характер і не дозволяють в повному обсязі відкрити весь потенціал фінансового сектору в економіці нашої країни.

Розвиток економіки держави стає не можливим без розвинутого, стабільного, та ефективного фрінансового ринку. Останнім часом на фінансовому ринку відбуваються процеси, які мають негативні тенденції та вказують на необхідність негайної розробки та впровадження інноваційних, а часом і радикальних заходів щодо рефрормування всього фінансового ринку. Цілком $є$ зрозумілим, що на фрінансовому ринку необхідно впроваджувати кардинально нові фрінансові інструменти та методи управління [5].

Орієнтованість учасників фрінансового ринку на отримання швидких прибутків, а також відсутністю довіри населення до фінансово-кредитних установ провокують нестабільність вітчизняної фінансової системи. Для того, щоб фінансовий ринок став одним з основних механізмів концентрації вільних ресурсів для розвитку економіки і формування надійних інструментів заощадження для населення потрібна стабілізація валютного ринку та фрінансового сектора, зниження та утримання рівня інфляції на прийнятному для розвитку економіки рівні, відновлення довіри населення до інститутів фрінансового ринку [6].

Для досягнення стабільності фрінансової системи держави, мобілізації та перерозподілу фрінансових ресурсів необхідно слідкувати за розвитком фрінансового ринку країни. Стратегія розвитку фінансового ринку України надасть можливість забезпечити його прозорість, створить сприятливі умови для потенційних інвесторів і підвищить ліквідність фрінансових інструментів ринку. Для цього потрібно впровадити цілісну довгострокову стратегію розвитку фрінансового ринку.

\section{Список використаних джерел:}

1. Кізима, Т. О. \& Луцишин, О. О. (2016). Аналітичний огляд інфрраструктури фінансового ринку України: інституційний аспект. Наукові записки Національного університету «Острозька академія», (2), 62-68.

2. Савінова, Ю. М. Особливості розвитку фінансового ринку України як основи функціонування системи фрінансового посередництва. Вилучено 3 http://www.economy.nayka.com.ua/?op=1\&z=2042.

3. Іванілов, О. С. (2009). Економіка підприємства. Київ: Центр учбової літератури.

4. Базилевич, В. (2009). Розвиток фінансового ринку в сучасних умовах. Фінанси України, (12), 5-12.

5. Адаменко, І.П. (2018). Особливості розвитку фінансового ринку України. Економічна наука. Інвестииіі:: практика та досвід, (9), 13-17.

6. Дешко, А. П'ять кроків, які врятують фрінансовий ринок України. Вилучено з http://gazeta.dt.ua/macrolevel/. 


\title{
СУЧАСНІ РЕАЛІЇ ТА ТЕНДЕНЦІЇ РОЗВИТКУ СТРАХОВОГО РИНКУ УКРАЇНИ
}

\begin{abstract}
Бинда Ганна Володимирівна
студентка

коледж Чернівецького національного університету імені Юрія Федьковича НАУКОВИЙ КЕРІВНИК: Томашевська Альона Миколаївна викладач коледж Чернівецького національного університету імені Юрія Федьковича УКРАЇНА
\end{abstract}

На сьогоднішній день, діяльність страхових компаній в Україні має позитивну динаміку розвитку. Саме страхові компанії є важливим компонентом формування економіки країни, адже забезпечують страхову стабільність в країні та страховий захист фізичним та юридичним особах в умовах певних страхових подій, що зменшує витрати держави на відшкодування збитків, які бути одержані в наслідок різноманітних природних лих, непередбачуваних ситуацій, втрати працездатності чи проблем зі здоров'ям та життям. Також страхові фонди надають певну гарантію та стимулюють розвиток активного капіталовкладення.

Страховий ринок - особлива сфрера грошових відносин, де об'єктом купівліпродажу виступає специфічна послуга - страховий захист, фрормується пропозиція і попит на неї [1].

Учасниками страхового ринку $€$ страхувальники, застраховані, вигодонабувачі, страховики, перестраховики, товариства взаємного страхування, страхові та перестрахові брокери, страхові агенти, актуарії, аварійні комісари, а також професійні об'єднання страховиків, страхових посередників та інших учасників страхового ринку [2].

Досліджуючи світовий страховий ринок можна дійти висновку, що вони можуть акумулювати кошти в деякій мірі більші, ніж банки. Страхові компанії забезпечують захист людських інтересів здебільшого у всіх розвинутих країнах. Зокрема в Західній Європі, Північній та Латинській Америці надзвичайно популярно і навіть необхідно страхувати не лише своє майно, а й здоров'я, пенсії, та життя. Зокрема, в Німеччині страхування життя $є$ одним з найпопулярніших видів страхування. Англія та Японія використовують пенсійне страхування, як найбільш масовий і популярний вид забезпечення старості [3].

Розвиток страхових компаній в Україні супроводжується низкою проблем, що гальмують його. Зокрема, кризовий стан економіки країни, недосконалість регулювання і удосконалення страхової діяльності з боку держави, недовіра серед користувачів. Це не дозволяє страховим компаніям виконувати свої функції в повній мірі і впливати на розвиток економіки країни.

3 розвиток нових технологій страхові компанії змушені надавати користувачам оновлені досконалі послуги, які укріплюються новими технологічними здобутками і збільшувати спектр своїх гарантій задля втримання конкурентоспроможності у важких політичних та економічних умовах. Не дивлячись на тенденції розвитку страхові компанії в Україні 
наштовхуються на чималі ризики своєї діяльності, що пов'язано з економічною нестабільністю в країні.

Загальна кількість страхових компаній в Україні станом на 31.12.2018 становила 281, у тому числі страхові компанії «life» - страхові компанії, що здійснюють страхування життя - 30 компаній, страхові компанії «non-life» страхові компанії, що здійснюють страхування видів, інших, ніж страхування життя - 251 компанія, (станом на 31.12.2017 - 294 компанії, у тому числі СК «life» - 33 компанії, СK «non-life» - 261 компанія). Кількість страхових компаній має тенденцію до зменшення, так за 2018 рік, кількість компаній зменшилася на 13, порівняно з 2017 роком. У 2017 році зменшилося на 29 страхових компаній, порівняно з 2016 роком [4].

За 2018 рік частка валових страхових премій у відношенні до ВВП становила 1,4\%, що на 0,1 в.п. менше в порівнянні з 2017 роком; частка чистих страхових премій у відношенні до ВВП залишилась на рівні 2017 року та становила 1,0\%. У порівнянні з 2017 роком на 5 935,7 млн. грн. (13,7\%) збільшився обсяг надходжень валових страхових премій, обсяг чистих страхових премій збільшився на 5 929,9 млн. грн. (20,8\%) [4].

Аналіз стану та структури страхового портфеля страхових компаній на фрінансовому ринку України представлено в таблиці 1.

Таблиця 1

Аналіз стану та структури страхового портоеля (валові страхові премії) страхових компаній на фінансовому ринку України за 2016 - 2018 роки

\begin{tabular}{|c|c|c|c|c|c|c|c|}
\hline \multirow{3}{*}{ Види страхування } & \multicolumn{6}{|c|}{ Роки } & \multirow{3}{*}{$\begin{array}{c}\text { Темп } \\
\text { приросту } \\
\text { страхових } \\
\text { премій } \\
\text { у } 2018, \%\end{array}$} \\
\hline & \multicolumn{2}{|c|}{2016} & \multicolumn{2}{|c|}{2017} & \multicolumn{2}{|c|}{2018} & \\
\hline & млн. грн. & $\%$ & млн. грн. & $\%$ & млн. грн. & $\%$ & \\
\hline $\begin{array}{l}\text { Автострахування (КАСКО, } \\
\text { ОСЦПВ, "Зелена картка") }\end{array}$ & 9277,5 & 26,4 & 10613,0 & 24,4 & 12975,1 & 26,3 & 22,3 \\
\hline Страхування життя & 2756,1 & 7,8 & 2913,7 & 6,7 & 3906,1 & 7,9 & 34,1 \\
\hline $\begin{array}{l}\text { Медичне страхування } \\
\text { (безперервне страхування } \\
\text { здоров'я) }\end{array}$ & 2355,5 & 6,7 & 2881,3 & 6,6 & 3486,7 & 7,1 & 21,0 \\
\hline Страхування майна & 4142,4 & 11,8 & 5098,9 & 11,7 & 6440,2 & 13,0 & 26,3 \\
\hline $\begin{array}{l}\text { Страхування фінансових } \\
\text { ризиків }\end{array}$ & 3596,7 & 10,2 & 5594,4 & 12,9 & 5135,5 & 10,4 & $-8,2$ \\
\hline $\begin{array}{l}\text { Страхування відповідальності } \\
\text { перед третіми особами }\end{array}$ & 2093,9 & 6,0 & 2925,0 & 6,7 & 2567,2 & 5,2 & $-12,2$ \\
\hline $\begin{array}{l}\text { Страхування від вогневих } \\
\text { ризиків та ризиків стихійних } \\
\text { явищ }\end{array}$ & 2551,9 & 7,3 & 3598,1 & 8,3 & 4497,1 & 9,1 & 25,0 \\
\hline $\begin{array}{l}\text { Страхування від нещасних } \\
\text { випадків }\end{array}$ & 837,1 & 2,4 & 1308,5 & 3,0 & 1754,2 & 3,6 & 34,1 \\
\hline $\begin{array}{l}\text { Страхування вантажів та } \\
\text { багажу }\end{array}$ & 4374,6 & 12,4 & 4686,7 & 10,8 & 2899,0 & 5,9 & $-38,1$ \\
\hline Страхування медичних витрат & 727,0 & 2,1 & 891,0 & 2,1 & 1345,9 & 2,7 & 51,1 \\
\hline Авіаційне страхування & 501,1 & 1,4 & 764,3 & 1,8 & 1041,7 & 2,1 & 36,3 \\
\hline Страхування кредитів & 531,0 & 1,5 & 365,0 & 0,8 & 1113,6 & 2,3 & 205,1 \\
\hline $\begin{array}{l}\text { Страхування від нещасних } \\
\text { випадків на транспорті }\end{array}$ & 85,4 & 0,2 & 86,1 & 0,2 & - & - & -100 \\
\hline Інші види страхування & 1340,1 & 3,8 & 1705,8 & 3,9 & 2205,2 & 4,5 & 29,3 \\
\hline Всього & 35170,3 & 100 & 43431,8 & 100 & 49367,5 & 100 & 13,7 \\
\hline
\end{tabular}

взято 3 [4] 
Протягом аналізованого періоду (табл. 1), збільшення валових страхових премій відбулося майже по всім видам страхування, а саме: автострахування (КАСКО, ОСЦПВ, «Зелена картка») (збільшення валових страхових платежів на 2362,1 млн. грн. (22,3\%)); страхування майна (збільшення валових страхових платежів на 1341,3 млн. грн. (26,3\%)); страхування життя (збільшення валових страхових платежів на 992,4 млн. грн. $(34,1 \%)$ ); страхування від вогневих ризиків та ризиків стихійних явищ (збільшення валових страхових платежів на 899,0 млн. грн. $(25,0 \%)$ ); страхування кредитів (збільшення валових страхових платежів на 748,6 млн. грн. (2 рази)); медичне страхування (збільшення валових страхових платежів на 605,4 млн. грн. $(21,0 \%))$; страхування медичних витрат (збільшення валових страхових платежів на 454,9 млн. грн. (55,1\%)); страхування від нещасних випадків (збільшення валових страхових платежів на 445,7 млн. грн. (34,1\%)) [4].

У 2018 році, від'ємну динаміку мають такі види страхування: обсяг валових страхових премій зі страхування фрінансових ризиків скоротився на 458,9 млн. грн., порівняно з 2017; зі страхування відповідальності перед третіми особами - на 357,8 млн. грн.; зі страхування вантажів та багажу - на 1787,7 млн. грн., а його частка у страховому портфелі зменшилася майже вдвічі і становила $5,9 \%$.

У 2016 році страхування життя становило 7,8\% від загального обсягу страхового портфеля страховиків, а у $2017-6,7 \%$.

За 12 місяців 2018 року сума отриманих страховиками валових премій 3 видів страхування, інших, ніж страхування життя становила 45461,4 млн. грн.

Розглянути динаміку обсягу валових страхових премій страховиків України за 2016 - 2018 роки, можна на рисунку 1.

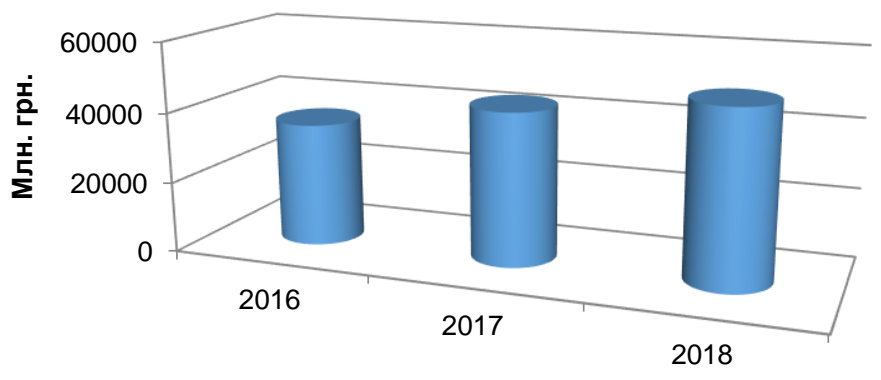

- Валові страхові премії

\section{Рис. 1. Динаміка обсягу валових страхових премій страховиків України за 2016 - 2018 роки}

Як бачимо (рис. 1), за аналізований період, валові страхові премії страхового портфеля страховиків мають зростаючу динаміку, що свідчить про зростання попиту на страхові продукти серед населення України, а також, розвиток страхової діяльності в країні.

3 проведеного аналізу можна зробити висновок, що кількість страхових компаній в Україні, за досліджуваний період, зменшилася. Проте, сукупний обсяг страхового портфеля страхових компаній має тенденцію до зростання. На страховому ринку основну частку валових страхових премій - 97,9\% акумулюють страхові компанії «non-Life». Основним видом страхування в 
портфелі страховиків України є автострахування (КАСКО, ОСЦПВ, «Зелена картка»).

Отже, страховий ринок України перебуває на етапі фрормування, поступово адаптуючись до вимог європейського та світового ринків. 3 метою покращення ситуації вітчизняним страховикам необхідно переймати зарубіжний страховий досвід та змінювати власні моделі функціонування, зокрема: вдосконалювати механізм державного регулювання діяльності страхових компаній; адаптувати до світових стандартів страхове законодавство; впроваджувати новітні страхові продукти.

\section{Список використаних джерел:}

1. Воробйов ,Ю.Н., Воробйова Є.І. \& Ворошило В.В. (2006). Страхування в Україні: тенденції й особливості розвитку. Економіка та управління, (2-3), $20-25$.

2. Павлюченко, Т. (2006) Инвесторы грядут. Финансы для всех, (7), 26 - 35.

3. Страхування життя та пенсійне страхування. Досвід Німеччини та країн, які вступили до ЄС. Вилучено 3 https://forinsurer.com/public/07/01/20/2801

4. Офріційний сайт Національної комісії, що здійснює державне регулювання у сфері ринків фінансових послуг. Вилучено з http://nfp.gov.ua

\section{ФИНАНСОВОЕ ОБЕСПЕЧЕНИЕ ТУРИСТИЧЕСКИХ ПРЕДПРИЯТИЙ}

Юлия Анатолиевна Бондарь
канд. экон. наук, доцент, доцент кафедры менеджмента экономики и туризма
Летная академия Национального авиационного университета

Евгения Шестина

магистрант кафедры менеджмента экономики и туризма Летная академия Национального авиационного университета

УКРАИНА

В современных условиях хозяйствования возникает необходимость изучения воздействия механизма финансового обеспечения (нормативноправовой базы, методов, источников финансового обеспечения, финансовых инструментов, стимулов, санкций) и его адаптации с учетом специфики объекта управления.

Финансовое обеспечение туристической отрасли имеет ряд особенностей и специфических черт, связанных прежде всего с механизмом ее функционирования. В основном эта отрасль нуждается в финансировании в смежные сореры деятельности (гостиничное и ресторанное хозяйство, различные виды транспорта и его инфраструктуру, учреждения развлечений, народные промыслы и др.), а с другой стороны, социальный эффект заключается в том, что модернизированная инфраструктура используется не только туристами, но и местным населением. Реализации фринансового обеспечения субъектов хозяйствования туристической отрасли в отечественных условиях включает ряд определенных фракторов [3]. 
Финансы туристического предприятия представляют совокупность денежных отношений, возникающих при формировании, использовании и обороте денежных фондов и накоплении предприятия. Задачей туристического предприятия является использование денежных средств на основе эффрективного управления в целях осуществления своей деятельности, получения прибыли и обеспечения финансовой устойчивости.

В ходе производственно-обслуживающего процесса туристического предприятия возникают следующие финансовые отношения [1]:

1. Турагента с туроператором по расчетам за полученные туристические путевки и по другим платежам.

2. Туристического предприятия с:

- органами жилищно-коммунального хозяйства по оплате аренды и коммунальных услуг;

- муниципальным управлением при выплате арендной платы за земельный участок;

- своими работниками по выплате заработной платы, премий и т. п.;

- при других банковских операциях;

- бюджетом и налоговыми службами при внесении налогов и других платежей и т. д.

В результате фринансовых отношений фрормируются фринансовые ресурсы предприятия. Важнейшими источниками формирования фринансовых ресурсов являются:

— прибыль от всех видов хозяйственной деятельности;

- доходы, полученные от продажи ненужного имущества;

- доходы (дивиденды) по акциям и другим ценным бумагам, принадлежащим туристскому предприятию;

- вклады учредителей в уставный фонд;

- краткосрочные и долгосрочные кредиты и займы;

- доходы от финансовых операций и прочих поступлений.

Все источники фринансовых ресурсов по режиму использования делятся на:

- собственные и приравненные к ним средства;

- заемные средства;

- привлеченные средства.

Собственные фринансовые ресурсы туристического предприятия представляют базовую и основную часть всех финансовых ресурсов, которая образуется и находится в их распоряжении. Эта часть называется уставным фондом. Основным источником его пополнения является прибыль, а также паевые и иные взносы, выпуск и продажа акций. Действующим законодательством установлены минимальные размеры уставного фонда. К собственным средствам приравниваются так называемые устойчивые пассивы. К ним относятся: переходящая задолженность работникам предприятия по зарплате и отчислениям в специальные налоговые фонды, задолженность партнерам и потребителям по полученным авансам, кредиторская задолженность и др. [2].

Заемные финансовые средства предприятия представляют собой краткосрочные и долгосрочные кредиты банков, ссуды. 
Привлеченные финансовые средства других предприятий, временно находящиеся в обороте в связи с существующей системой расчетов (задолженность кредиторам, доходы будущих периодов и др.).

Финансовые ресурсы используются предприятием в процессе производственной и инвестиционной деятельности.

Инвестиции в туризм представляют собой создание с помощью капитала новых туристских объектов, модернизацию или реконструкцию существующих, способных производить и оказывать определенные виды туристских услуг, а также нематериальных активов (изобретения, ноу-хау и т.д.).

Задачами туристического предприятия являются формирование денежных фондов и их использование на основе эффрективного управления денежным потоком в целях осуществления производственно-обслуживающей и финансовой деятельности, получения прибыли, обеспечения финансовой устойчивости.

Таким образом, учитывая, что с одной стороны, туризм является сложной системой и привлекает к своему функционированию большое количество смежных отраслей, а с другой - приоритетность его развития для экономики страны ставит перед нашем государством создание обоснованного финансово-инвестиционного механизма обеспечения дальнейшего его развития.

Финансовые инструменты, обеспечивающие развитие туристической отрасли, включают:

1) бюджетное финансирование программ развития туризма, лизинг;

2) кредитования (предоставления кредитов на льготных условиях для фринансирования туристических объектов; снижение процентных ставок банковского кредитования);

3) налоговые льготы (освобождение от части налогов) под конкретные проекты, оптимизация количества, уменьшение ставок налогов и сборов, уменьшение налогового давления на субъекты туристической деятельности;

4) поддержка предприятий банками, страховыми компаниями, корпорациями и др.

Таким образом финансовое обеспечение туристической отрасли представляет собой систему взаимоотношений, определяет принципы, источники и формы фринансирования субъектов хозяйствования, деятельность которых направлена на создание комплексного туристического продукта и удовлетворения потребностей населения в туристических услугах. Финансовое обеспечение должно стать основой государственной туристической политики и способствовать развитию экономического потенциала страны.

\section{Список использованных источников:}

1. Биржаков, М.Б. \& Никифоров, В.И. (2003). Индустрия туризма: перевозки Москва: ИД Герда.

2. Жуйриков, К.К. \& Раимов, С.Р. (2004). Экономика и статистика: Корпоративные финансы. Академия экономики и статистики.

3. Захарчук, С. (2010). Фінансово-економічні проблеми функціонування туристичної галузі Економіка. Управління. Інновації. (1), Вилучено із http://www.nbuv.gov.ua/ejournals/eui/2010_1/10zsstgu.pdf. 


\title{
SECTION II. AGRICULTURAL SCIENCES
}

DOI 10.36074/13.12.2019.v2.01

\section{АСОЦІАЦІЯ МІЖ РОСТОВИМИ ОЗНАКАМИ М'ЯСНОÏ ХУДОБИ ТА ГЕНЕТИЧНИМ ПОЛІМОРФІЗМОМ МІКРОСАТЕЛІТНОÏ̈ ДНК}

\begin{abstract}
Крамаренко Олександр Сергійович
канд. с.-г. наук, старший викладач кафедри технології переробки, стандартизації і сертифікації продукції тваринництва Миколаївський національний аграрний університет
\end{abstract}

УКРАÏHA

Попри те, що а-priori мікросателіти ДНК є нейтральними молекулярногенетичними маркерами, починаючи з середини 1990-х років з'явились повідомлення про виявлені вірогідні зв'язки між наявністю/відсутністю тих або інших алелей досліджуваних локусів мікросателітів та різними показниками продуктивності сільськогосподарських тварин, у тому числі й ВРХ.

Так, було встановлено, що алелі ВM1500 136 та ВM1500138 є маркерами кращого надою і найвищого вмісту жиру в молоці, відповідно, у різних порід BPX. У корів м'ясного напряму продуктивності (помісі Piemontese x Chiniana) алель IIDVGA46205 виявився маркером бажаних для селекції промірів тіла, таких як висота в холці, ширина та глибина грудей і т.і. Ціла низка мікросателітних локусів геномної ДНК (ILSTS005, ILSTS006, TGLA227, INRA035, BM2113, CSSM66) тісно пов'язана із стійкістю зебу до туберкульозу [1].

Головною метою роботи став аналіз асоціації між ростовими ознаками та мікросателітами ДНК у південної м'ясної породи худоби. Цю породу було створена шляхом міжвидової гібридизації Bos indicus $\times$ Bos taurus за використанням генетичного матеріалу таких порід, як червона степова, шортгорн, санта-гертруда, герефрорд, шароле та кубинський зебу [2].

В якості показників динаміки живої маси молодняку були використані наступні: жива маса при народженні (М0), в 210 діб (при відлученні; M210d), у віці 8 міс. (M8), 12 міс. (M12), 15 міс (M15) та 18 міс (М18). Окрім цього, застосовано три показники інтенсивності росту: середньодобовий приріст від народження до віку 18 міс. (ADG), середньодобовий приріст від народження до відлучення (ADG1) та середньодобовий приріст від відлучення до віку 18 міс. (ADG2). Основу експерименту складала перевірка нуль-гіпотези щодо відсутності відмінностей за показниками росту живої маси між тваринами, що мали певні алелі за локусами мікросателітів [3].

В результаті проведеного аналізу, нами була встановлена наявність вірогідних зв'язків між присутністю/відсутністю окремих алелів використаних мікросателітних локусів ДНК і мірою прояву показників інтенсивності росту молодняку південної м'ясної породи (табл. 1). 
Результати однофакторного дисперсійного аналізу впливу присутності окремих алелей локусів мікросателітів ДНК на показники інтенсивності росту молодняку південної м'ясної породи

\begin{tabular}{|c|c|c|c|c|c|c|c|c|c|}
\hline \multirow[t]{2}{*}{ Локус } & \multicolumn{9}{|c|}{ Показники росту і розвитку } \\
\hline & M0 & M210d & M8 & M12 & M15 & M18 & ADG & ADG1 & ADG2 \\
\hline TGLA227 & * & * & ns & ns & ns & $\left({ }^{*}\right)$ & * & * & ** \\
\hline BM2113 & ns & ns & ns & $\mathrm{ns}$ & $\mathrm{ns}$ & ns & ns & ns & ns \\
\hline TGLA53 & ns & $\mathrm{ns}$ & $\left({ }^{*}\right)$ & ns & ns & ns & ns & ns & $\mathrm{ns}$ \\
\hline ETH10 & ns & ns & ns & ns & ns & ns & ns & $\mathrm{ns}$ & ns \\
\hline SPS115 & ns & ns & ns & ns & ns & ns & ns & ns & ns \\
\hline TGLA122 & $\left({ }^{*}\right)$ & $\mathrm{ns}$ & ns & $\mathrm{ns}$ & $\mathrm{ns}$ & $\mathrm{ns}$ & ns & ns & * \\
\hline INRA23 & $\mathrm{ns}$ & $\mathrm{ns}$ & $\mathrm{ns}$ & $\mathrm{ns}$ & $\mathrm{ns}$ & $\mathrm{ns}$ & $\left({ }^{*}\right)$ & $\mathrm{ns}$ & $\mathrm{ns}$ \\
\hline TGLA126 & ns & ns & ns & ns & $\mathrm{ns}$ & ns & ns & ns & ns \\
\hline BM1818 & ns & * & $\mathrm{ns}$ & $\mathrm{ns}$ & $\mathrm{ns}$ & $\mathrm{ns}$ & $\mathrm{ns}$ & * & ns \\
\hline ETH3 & ns & ns & ns & $\mathrm{ns}$ & $\mathrm{ns}$ & $\mathrm{ns}$ & ns & ns & $\mathrm{ns}$ \\
\hline ETH215 & ns & $\mathrm{ns}$ & ns & ns & ns & $\mathrm{ns}$ & $\mathrm{ns}$ & ns & $\mathrm{ns}$ \\
\hline BM1824 & $\left(^{*}\right)$ & * & * & $\left({ }^{*}\right)$ & $\left({ }^{*}\right)$ & * & $\left({ }^{*}\right)$ & * & ns \\
\hline
\end{tabular}

Примітка: $n s-p>0,1 ;\left(^{*}\right)-0,1<p<0,05 ;^{*}-p<0,05 ;{ }^{* *}-p<0,01$.

В найбільшому ступеню такий зв'язок було встановлено між більшістю використаних показників та локусами TGLA227 і BM1824. Так, наприклад, тварини, у яких в генотипі був присутнім хоч би один алель TGLA22785, характеризувалися найвищими оцінками середньодобового приросту на відгодівлі (675 г), проте як у більшості інших тварин цей показник не перевищував 450-550 г. Аналогічним чином, тварини, в яких у генотипі був присутнім хоч би один алель ВM1824 ${ }^{178}$ (або ВМ1824 ${ }^{180}$ ), характеризувалися найвищими оцінками середньодобового приросту від народження до відлучення - 780-830 г., але в інших особин цей показник рідко перевищував 700 г.

Більш детальний пошук можливих асоціацій між окремими алелями мікросателітів ДНК, використаних при аналізі генетичної мінливості молодняку південної м'ясної породи, був зроблений нами на основі розділення усіх досліджених тварин на дві групи - тих, що мають певний алель і, відповідно, не мають його.

У таблиці 2 наведено отримані нами результати, що відображують наявність асоціацій між показниками інтенсивності росту молодняку південної м'ясної породи та наявністю в їх генотипі тих або інших алелів досліджуваних локусів мікросателітної ДНК. При використанні цього підходу виявлена більша кількість таких можливих асоціацій.

Так, жива маса при народженні тісно пов'язана з наявністю в генотипі тварин алелів TGLA22785 або TGLA22795. У цьому випадку ця ознака виявляється в середньому вище на 3,7 і 4,3 кг, відповідно, в порівнянні 3 особинами, в яких у генотипі ці алелі відсутні (у обох випадках: $p<0,05$ ). Призводить до підвищення живої маси при народженні і наявність алеля ETH10221 - в середньому на 3,1 кг $(p<0,05)$. Менш виражений вплив на живу масу при народженні відмічено для алеля BM1824 ${ }^{178}(1,8$ кг; $p<0,05)$.

У той же час, особини, в генотипі яких було відмічено алелі TGLA122 ${ }^{149}$ та ВМ1818260, поступалися своїм ровесницям в середньому на 1,8 і 2,5 кг (у обох випадках: $p<0,05)$. 
Problems and prospects of implementation of innovative research results $\bullet$ Volume 2

Таблиця 2

Асоціації між показниками інтенсивності росту молодняку південної м'ясної породи і наявністю в їх генотипі алелів досліджуваних локусів

мікросателітної ДНК

\begin{tabular}{|c|c|c|}
\hline \multirow{2}{*}{$\begin{array}{c}\text { Показники } \\
\text { росту і } \\
\text { розвитку }\end{array}$} & \multicolumn{2}{|c|}{ Алелі } \\
\hline & позитивно пов'язанні & негативно пов'язанні \\
\hline Mo & $\begin{array}{l}\text { TGLA22785; TGLA22795; } \\
\text { ETH10221; SPS115 }{ }^{254} ; \text { BM1824 }{ }^{178}\end{array}$ & TGLA122 ${ }^{149} ; \mathrm{BM} 1818^{260}$ \\
\hline M210d & $\begin{array}{l}\text { TGLA227 } \\
\text { BM1824 }{ }^{880}\end{array}$ & INRA23 $3^{216}$ \\
\hline M8 & TGLA227 $7^{85} ; \mathrm{BM} 1824^{178}$ & INRA23 216 \\
\hline M12 & TGLA22785; BM1818 258; BM1824178 & INRA23216 \\
\hline M15 & TGLA227 $^{85} ; \mathrm{BM} 1824^{178}$ & BM2113 ${ }^{141}$ \\
\hline M18 & TGLA227 $^{85} ; \mathrm{BM} 1824^{178}$ & $\mathrm{BM}_{2113^{141}} ;$ INRA23 $3^{208}$ \\
\hline ADG & TGLA227 $7^{85} ; \mathrm{BM} 1824^{178}$ & BM2113 ${ }^{141} ;$ INRA23 ${ }^{208}$; INRA23 $3^{214}$ \\
\hline ADG1 & $\begin{array}{l}\text { TGLA22783; BM1818 } \\
\text { BM1828; BM1824 }{ }^{178} ;\end{array}$ & INRA23 216 \\
\hline ADG2 & TGLA227 $7^{85} ;$ TGLA122 $^{153} ;$ BM1824 $^{178}$ & INRA23 $^{214} ; \mathrm{BM} 1818^{260} ; \mathrm{BM}^{2} 824^{180}$ \\
\hline
\end{tabular}

Примітка: Курсивом виділені алелі, для яких 0,05 <p<0,1.

Характерно, що на живу масу при відлученні і у більш старшому віці, відмічено вплив вже зовсім інших алелів. Це може свідчити про відмінності процесів генетичної детермінації росту тварин на різних етапах постнатального онтогенезу.

Так, особини, що мають в генотипі алель TGLA227 83 при відлученні були в середньому на 27,5 кг важче, ніж їх ровесниці, у яких цей алель був відсутній $(p<0,05)$.

Подібна різниця $(27,2$ кг) була встановлена у худобі при відлученні між особинами, які мали і у яких був відсутній алель $\mathrm{BM} 1818^{258}(p<0,05)$. Менш виражені відмінності за живою масою при відлученні були відмічені для алелів BM1824 ${ }^{178}$ та BM1824 ${ }^{180}$ (20,9 і 12,7 кг; у обох випадках: $\left.p<0,05\right)$.

3 іншого боку, наявність алеля INRA23216 призводила до зниження живої маси при відлученні в середньому на 59,0 кг $(p<0,05)$.

Жива маса у віці вісім і 12 місяців характеризується практично тими ж асоціаціями з алелями мікросателітних локусів ДНК, що і жива маса при відлученні (див. табл. 2).

Для живої маси у віці 15 та 18 місяців нами було встановлено наявність негативної асоціації з алелем ВM2113 ${ }^{141}$ - особини, які мали цей алель, виявилися в середньому на 38,0 і 42,5 кг легше, відповідно (у обох випадках: $p<0,05)$.

Інтенсивність ростових процесів живої маси молодняку південної м'ясної породи (як в цілому - від народження до віку 18 міс., так і на різних етапах постнатального онтогенезу - від народження до відлучення і на відгодівлі) також характеризувалася значними асоціаціями з наявністю тих або інших алелів мікросателітної ДНК (див. табл. 2).

Так, середньодобовий приріст живої маси від народження до віку 18 міс. був істотно вищий у тварин, які мають алелі TGLA22785 (на 194 г) і ВM1824 ${ }^{178}$ (на 93 г), в порівнянні з тваринами, в яких ці алелі відмічено не було (в обох випадках: $p<0,05)$. 
3 іншого боку, наявність у худоби алелів BM2113 141 і INRA23 214 , навпаки, призводило до вірогідного зниження середньодобових приростів у середньому на 72 і 43 г (в обох випадках: $p<0,05)$.

На характер середньодобового приросту у період від народження до відлучення встановлено позитивний вплив наявних у геномі особин алелів TGLA22783, BM1818258, BM1824178 та BM1824180 (в усіх випадках: $p<0,05$ ). Причому, асоціація з першими двома алелями носила яскравіший характер, що виражається у більш відчутній різниці (129 та 126 г, відповідно) і, отже, більш високому рівні значущості ( $p=0,011$ та $p=0,002$, відповідно). Проте наявність алеля INRA23216, навпаки, призводила до зниження величини середньодобового приросту на цьому етапі оцінки онтогенезу телят (на 284 г; $p<0,01)$.

Приріст же живої маси на відгодівлі характеризується своїм власним набором асоціацій, причому, для деяких локусів і/або алелів напрям цих зв'язків може змінюватися на протилежне, що свідчить про прояв компенсаторних механізмів, що детермінують ріст та розвиток тварин, у т.ч. і південної м'ясної породи.

Так, на середньодобовий приріст на відгодівлі встановлено позитивний вплив алеля TGLA22785, присутність якого в генотипі підвищує приріст на 220 г $(p=0,011)$. Аналогічною $€$ дія алеля BM1824 ${ }^{178}$ (підвищує приріст на 67 г; $p=0,050)$. Проте, при цьому, наявність алеля BM1824 ${ }^{180}$, навпаки, призводить до зниження середньодобового приросту на відгодівлі на 46 г; $p<0,05)$. Хоча раніше було відмічено позитивний вплив цього алеля на живу масу дослідних тварин при відлученні (див. табл. 1).

Присутність алеля ВМ1818 260 , також, негативно впливає на середньодобовий приріст телят у вищевказаний період (на 90 г; $p=0,023$ ), хоча раніше алелі цього локусу, навпаки, характеризувалися наявністю позитивних асоціацій з показниками живої маси молодняку південної м'ясної породи. 3 іншого боку, нами було відмічено негативний вплив цього ж алеля на живу масу при народженні (див. табл. 2).

До специфічних для цього показника, мабуть, слід віднести і алель TGLA122 ${ }^{153}$, присутність якого у особин південної м'ясної породи призводить до підвищення середньодобового приросту на відгодівлі на 142 г $(p=0,010)$.

Характерно, що більшість алелів, для яких було відмічено вірогідну асоціацію з інтенсивністю росту, зустрічаються з відносно низькою частотою (менше 0,15). Виняток становлять тільки алелі INRA23 ${ }^{214}$ та BM1824 ${ }^{180}$, частота яких в популяції складає близько 0,375 та 0,417, відповідно. Скоріш за все це можна пояснити випадковістю утворення таких генотипів через ефект «просковзування» мікросателітів. Або особливостями нормального розподілу, при якому тварини із найвищими/найнижчими значеннями зустрічаються у вибірці із дуже низькою частотою.

Крім того, переважна більшість алелів, наведених в табл. 2, $є$ специфічними для тварин різних дослідних підтипів. Наприклад, алелі TGLA22783, ETH10221, INRA23 ${ }^{208}$, BM1818 ${ }^{258}$, BM1824 ${ }^{178}$ та BM1824 ${ }^{180}$ вірогідно частіше зустрічаються у худоби низькокровного підтипу, проте як алелі TGLA227 $7^{85}$, BM2113 ${ }^{141}$, TGLA122 149 та BM1818 ${ }^{260}$, навпаки, є специфічними для особин висококровного підтипу. При цьому, за рідкісним винятком, присутність 
у генотипі тварини алелів, характерних для висококровного підтипу пов'язано з нижчими оцінками показників живої маси або приростів на різних етапах, у той же час як, присутність алелів, специфічних для низькокровного підтипу, навпаки, з їх підвищенням.

3 іншого боку, нами було встановлено, що на усіх етапах росту молодняк висококровного підтипу поступався за живою масою ровесницям низькокровного підтипу. Отже, отримані нами асоціації можуть бути наслідком цих відмінностей, з одного боку, і наявністю специфічних алелів того або іншого підтипу тварин, з іншого.

Висновки. Таким чином, існує вірогідний зв'язок між присутністю/відсутністю певних алелів окремих використаних нами локусів мікросателітів ДНК і мірою прояву показників росту у досліджених особин таврійського внутрішньопородного типу південної м'ясної породи. Переважна більшість алелів, для яких відмічені вірогідні асоціації з показниками росту, $\epsilon$ специфічними для тварин різних підтипів.

Публікація містить результати досліджень, проведених за грантом Президента України для підтримки наукових досліджень молодих учених на 2019 рік (номер державної реєстрації 0119U103477).

\title{
Список використаних джерел:
}

1. Крамаренко, О.С. (2017). Оцінювання генетичної структури та прогнозування продуктивності тварин південної м'ясної породи за ДНК-маркерами. Миколаїв: «Іліон», $166 \mathrm{c}$.

2. Вдовиченко, Ю. В., Вороненко, В.І., Найдьонова, В. О., Омельченко, Л. О. (2012). М'ясне скотарство в степовій зоні України. Нова Каховка : ПИЕЛ, 307 с.

3. Халафян А. А. (2007). STATISTICA 6. Статистический анализ данных. Москва: ООО «Бином-Пресс», 512 c.

\section{ЕФЕКТИВНІСТЬ ВИРЩУВАННЯ БУРЯКА СТОЛОВОГО ПУЧКОВОЇ СТИГЛОСТІ}

\author{
Стефанюк Світлана Василівна \\ канд. С.-г. наук \\ Львівський національний аграрний університет \\ УKPAÏHA
}

Буряк столовий ціниться не лише коренеплодами, але й листками в фазі пучкової стиглості. В листках міститься більше мінеральних сполук, білків та вітамінів, ніж у коренеплодах. Вміст заліза в листках на порядок вище. Отже, молоді рослини буряка столового, які реалізують у фразі пучкової стиглості - $€$ особливим делікатесом [1].

Одним із важливих елементів технології вирощування пучкової продукції $€$ терміни сівби. Найбільш відомі два способи отримання пучкової продукції буряка столового: вирощування через розсаду та підзимова чи надрання сівба. 
Використовуючи підзимовий термін сівби, є ризик випадання рослин протягом зимових вікон, коли температура навколишнього середовища поступово підвищується до $10^{\circ} \mathrm{C}$ і вище [1].

Для більш раннього отримання урожаю буряка столового пучкової стиглості використовують накриття. Це може бути агроволокно, або поліетиленова плівка. Ефективність накриття зумовлена можливістю отримати високий урожай у несезонний період, коли ціни на продукцію значно вищі. Агроволокно - це дешевий і легкий вид накриття, який не потребує додаткових підпор $[1,2,3]$.

Нами проводились дослідження на полях кафедри садівництва та овочівництва Львівського національного аграрного університету упродовж 2016-2018 років на темно-сірому опідзоленому середньо-суглинковому ґрунті, відповідно до методики польових досліджень в овочівництві. Висівали буряк столовий сорту Бордо харківський у два терміни: підзимовий - сівба насіння буряка столового восени (до початку замерзання ґрунту); ранньовесняний сівба насіння буряка столового ранньою весною (за настання стиглості ґрунту). Для накриття рослин використовували агроволокно щільністю19 г/м².

За рослинами проводили догляд і спостереження. Урожай збирали вибірково, в міру наростання коренеплодів до фази пучкової стиглості. Дані наших досліджень розміщені у таблиці 1.

Важливим елементом технології одержання пучкової продукції буряка столового $€$ те, щоб при використанні додаткових заходів забезпечити надвишку урожаю, та високу рентабельність.

Таблиця 1

Ефективність вирощування буряка столового сорту Бордо харківський на пучкову продукцію. (Середнє 2016-2018 рр.)

\begin{tabular}{|c|l|c|c|c|}
\hline Термін сівби & Накриття & $\begin{array}{c}\text { Вихід пучків, } \\
\text { тис. шт./га }\end{array}$ & $\begin{array}{c}\text { Чистий } \\
\text { прибуток, } \\
\text { тис.грн./га }\end{array}$ & $\begin{array}{c}\text { Рівень } \\
\text { рентабельнос } \\
\text { ті, \% }\end{array}$ \\
\hline \multirow{2}{*}{$\begin{array}{c}\text { Підзимовий - } \\
\text { контроль }\end{array}$} & $\begin{array}{l}\text { Без накриття - } \\
\text { контроль }\end{array}$ & 47,8 & 49,1 & 139,2 \\
\cline { 2 - 5 } & Агроволокно & 54,1 & 120,6 & 167,4 \\
\hline $\begin{array}{c}\text { Ранньо- } \\
\text { весняний }\end{array}$ & $\begin{array}{l}\text { Без накриття - } \\
\text { контроль }\end{array}$ & 69,8 & 53,7 & 111,1 \\
\cline { 2 - 5 } & Агроволокно & 74,1 & 139,3 & 165,3 \\
\hline
\end{tabular}

Сівба насіння у підзимовий термін без накриття (контрольні варіанти) забезпечила 47,8 тис. шт./га пучків, а за накриття агроволокном - урожайність зросла на 6,3 тис. шт./га пучків. Чистий прибуток зростає на 71,5 тис. грн./га за використання агроволокна. Рівень рентабельності збільшується на 28,2 \% за накриття агроволокном в порівнянні з контролем (без накриття).

За ранньовесняного строку сівби урожайність становить 69,8 та 74,1 тис. шт./га пучків залежно від варіанта досліду. Відповідно, найбільший прибуток 139,3 тис. грн. /га отримали за накриття агроволокном, що більше на 85,6 тис. грн./га від контрольного варіанта (без накриття). Рівень рентабельності за використання агроволокна зріс на 54,2\%. 
Порівнюючи терміни сівби буряка столового - без накриття (контроль) за ранньовесняної сівби, одержали на 22,0 тис. шт./га пучків більше, а за накриття агроволокном - на 20,0 тис. шт./га пучків відповідно. Чистий прибуток збільшився на 4,6 тис. грн./га за ранньовесняного терміну сівби (без накриття) і на 18,7 тис грн./га за використання агроволокна.

У підзимового терміну сівби рівень рентабельності, на варіантах, як без накриття так і за використання агроволокна дещо вищий. Як бачимо з даних досліджень при застосуванні додаткових елементів технології вирощування буряка столового пучкової стиглості прибуток і рівень рентабельності зростають.

Тому, з метою одержання високого урожаю пучкової продукції буряка столового, насіння слід висівати якомога раніше застосовуючи як підзимовий так і ранньовесняний терміни сівби із накриттям агроволокном.

\section{Список використаних джерел:}

1. Хареба В.В. \& Стефанюк С.В. (2014). Буряк столовий: сорти, технологія вирощування. Аграрна наука НААН. Київ.

2. Стефанюк, С.В. \& Решетило, Л.І. (2017). Буряк столовий на ранню пучкову продукцію Матеріали всеукраїнської наукової конференції молодих учених, приуроченої 115-річчя від дня народження видатного селекціонера-плодовода Д.С. Дуки. Умань, 83-85

3. Стефанюк, С.В. \& Дусько, В.А. Рання продукція буряка столового. Збірник наукових праць «АОГОЦ» з Матеріалами Міжнародної науково-практичної конференції, Актуальні питання сьогодення. 20 березня 2018 р. м. Вінниця. 2018р. Том 7, 116-118.

\section{ЗБЕРЕЖЕННЯ ГІРСЬКОЇ ЛОКАЛЬНОЇ ПОРОДИ ПІНЦГАУ В КАРПАТСЬКОМУ РЕГІОНІ УКРАЇНИ}

\section{НАУКОВО-ДОСЛІДНА ГРУПА:}

Калинка Андрій Казимирович

канд. с.-г. наук, стариший науковий співробітник Буковинська державна сільськогосподарська дослідна станція НАAН

Лесик Оксана Богданівна

канд. с.-г. наук, стариший науковий співробітник Буковинська державна сільськогосподарська дослідна станція НАAН

Саранчук Іван Іванович канд. с.-г. наук, стариший науковий співробітник Буковинська державна сільськогосподарська дослідна станція НАAH УКРАÏHA

В сучасних умовах прискореного науково-технічного прогресу, коли ведуться селекційні роботи по створенню нових порід і типів жуйних, важливого значення набуває актуальна проблема з розроблення системи збереження і вдосконалення породного генофонду гірської худоби пінцгау в 
Буковинських Карпатах, яка добре адаптувалась до місцевих умов. На даний час ця унікальна порода ВPX перебуває на межі повного зникнення [2,4-5].

У зв'язку з наведеним вище необхідно розробити програму на державному рівні, щодо систему збереження та розпочати вже сьогодні інтенсивне практичне використання з використанням галузі м'ясного скотарства, як практикують вже століттями австрійські селекціонери та виробничники із застосуванням досягнень сучасних біотехнологічних методів з розведення зникаючої, локальної породи пінцгау в Карпатському регіоні України [8-11].

Пророблена в минулому наукова селекційна робота відносилася до самих актуальних в тому плані, що вперше було вивчено комплексний підхід, щодо розробки системи збереження гірської породи та іï раціонального використання у селекційному процесі з подальшим розробленням концепції розведення та збереження породи пінцгау в умовах Карпатського регіону України [2-3,6-7]. В даний час не ведеться науковий супровід за браком державних коштів на селекційну роботу по зникаючій гірській породі пінцгау, яка годує все населення гуцулів.

Метою публікації - показати та розробити вперше систему збереження гірської худоби та їх раціонального використання у селекційному процесі 3 використанням методів чистопородного розведення i ведення наукового супроводу в умовах гірського регіону Українських Карпат.

Тому наукова робота відноситься до самих перспективних і наукоємних та актуальних, коли було проведено аналіз патентної i науково-технічної інформації, яка засвідчувала про необхідність проведення наукових досліджень із забезпечення чистопорідного генофонду породи пінцгау 3 використанням прогресивної технології м'ясного скотарства у високогір'ї Карпатського регіону.

Наукова селекційна робота проводилась з розробки збереження тварин породи пінцгау та їх раціонального використання у селекційному процесі в умовах Карпат у таких господарствах Чернівецької області, НВА «Райдуга» (10гол.), ФГ «Світоч» (23 гол.), ФГ «Поляківське» (33 гол.), ФГ «Лоскун» (18 гол.), ФГ «Ялина» (14), ФГ «Гребень» (9 гол.), КС « Прикордонник» (8) ,, ФГ Бурчів (24 гол.), Путильського району, «Гуцулочка» (20 гол.), ФГ «Буковинське» (12 гол.).

В останні роки в період завершення реформування сільськогосподарських господарств та переходу в ринок внаслідок економічної нестабільності селекційно-племінна робота з даним поголів'ям породи погіршилась в гірських зонах Чернівецької та Івано-Франківської областей.

Дослідження необхідно проводити на перспективу з використанням нових методичних підходів:

1. Збереження генетичних резервів буде проводитися за рахунок довготермінового збереження замороженої сперми та заморожених яйцеклітин (ембріонів) та збереження і розведення "чистих” популяцій у вигляді генофондних стад із стабілізуючою селекцією.

2. Здешевлення останнього методу збереження - утримання генофондних стад, на другому етапі необхідно за рахунок реалізації племінної продукції для товарних стад породи пінцгау.

3. Для збереження генофонду породи пінцгау на майбутнє необхідно мати сперму, або ембріони мінімум від 25 неспоріднених бугаїв. Тому, програмою передбачено штучне осіменіння в більш широкому масштабі маток бажаного типу в господарствах зони Карпат, імпортною спермою бугаїв австрійського 
типу та наявною спермою в спермобанку Інституту розведення та генетики тварин ім.. М. В. Зубця, що не тільки зніме проблему чистопородного розведення в генофондних стадах в запобіганні інбридингу і генетичного дрейфу, а й дасть можливість вести селекцію по продуктивних екстер'єрноконституційних та інших показниках.

4. Перевагою вперше запропонованої роботи по збереженню генофонду породи пінцгау буде не тільки створення генофонду зникаючої породи, а i відновлення роботи їх стад, які тільки на першому етапі потребуватимуть певні одноразові затрати на придбання сперми і ембріонів та комплексу робіт по трансплантації, а також необхідності співробітництва із сусідніми країнами Австрією, Румунією по питаннях збереження генофонду, обміном інформацією, спермою цих порід та тваринами.

Селекційна робота по збереженню тварин породи пінцгау проводиться в основному у 2-х господарствах-репродукторах Чернівецької та в ФГ «Заріччя» Косівського району Івано-Франківської областей згідно перспективних планів, 3 координованих з програмою наукового забезпечення у рамках наукововиробничої системи та в населенні гірського регіону Карпат.

В селекційно-племінній роботі такі методи збереження генофонду породи:

- основним методом збереження були чистопорідне розведення колекцій "чистих" популяцій жуйних як вітчизняної, так і зарубіжної селекції у вигляді замкнутих генофондних стад;

- тривале збереження заморожених сперми та ембріонів у генетичних банках з метою збільшення поголів'я худоби пінцгау не виключена можливість використання поглинального схрещування та прилиття крові спорідненої породи.

В науковій роботі з формування збереженості із суб'єктів по системі збереженню гірської породи пінцгау були визначені генофондні стада, генофондні ферми та господарства, заказники. В роботі з раціональної форми збереження генофонду породи пінцгау було поголів'я в генофондних стадах (не менше 2 - 3 голови). До нині $є$ ще сформоване заповідне (реліктове) стадо місцевої зникаючої породи, яке організоване у НВА «Райдуга» с.Сергії Путильського району Чернівецької області і затверджені відповідним документом директивного органу.

Дослідженнями нашими проведено, що характеристика за молочною продуктивністю корів за лактаціями (жива маса телят у 210 днів) в основних господарствах розподілялася за наступним чином про що наведено у таблиці 1.

Таблиця 1

Характеристика корів за молочністю, кг

\begin{tabular}{|c|c|c|c|c|c|c|c|c|}
\hline \multirow{3}{*}{ № $\Pi / п$} & \multirow{3}{*}{ Господарства } & \multicolumn{6}{|c|}{ Отелення } & \multirow{3}{*}{$\begin{array}{c}\text { Середня } \\
\text { молочність за } \\
\text { всі } \\
\text { отелення, кг }\end{array}$} \\
\hline & & \multicolumn{2}{|c|}{$\mathrm{I}$} & \multicolumn{2}{|c|}{ II } & \multicolumn{2}{|c|}{ III } & \\
\hline & & $\begin{array}{c}\text { к-ть } \\
\text { голів }\end{array}$ & $\begin{array}{c}\text { क/M, } \\
\mathrm{K \Gamma}\end{array}$ & $\begin{array}{c}\text { к-ть } \\
\text { голів }\end{array}$ & $\begin{array}{c}\text { ж/M, } \\
\mathrm{K} \Gamma\end{array}$ & $\begin{array}{c}\text { к-ть } \\
\text { голів }\end{array}$ & $\begin{array}{c}\text { ж/M, } \\
\mathrm{K \Gamma}\end{array}$ & \\
\hline \multicolumn{9}{|c|}{ Чернівецька область } \\
\hline 1. & ФГ « Світоч» & 2 & 175 & 4 & 177 & 4 & 180 & 177,3 \\
\hline 2. & ФГ«Поляківське» & 2 & 171 & 4 & 175 & 6 & 178 & 174,7 \\
\hline 3. & ФГ « Бурчів» & 2 & 177 & 1 & 179 & 3 & 180 & 178,7 \\
\hline 4. & ФГ « Лостун» & 1 & 168 & 2 & 175 & 3 & 181 & 174,7 \\
\hline 5. & НВА «Райдуга» & 2 & 156 & 5 & 170 & 25 & 165 & 163,7 \\
\hline \multicolumn{9}{|c|}{ Івано-Франківська область } \\
\hline 1. & ПФГ «Заріччя» & 2 & 178 & 5 & 181 & 49 & 187 & 182,0 \\
\hline
\end{tabular}


Встановлено, що молочна продуктивність у 7 - місяців виявилась у ФГ«Заріччя « та у вище сказаному господарстві була майже однаковою i становила178 -181,3кг перша і друга та в третій лактації 187кг - 182,0кг. Як виявилось, що загальний добовий приріст молодняку (теличок і бугайців) в підсисній період по всіх господарствах склав 828 - 850 грамів, що на 157 кг $(13,1 \%$ більше за молодняк, який вирощувався за молочною галуззю за рік.

Результати досліджень свідчать, що нащадки від різних бугаїв при однакових умовах вирощування різнилося між собою за живою масою. Бугайці від батька бугая - плідника Функера 357 мають більший генетичний потенціал продуктивності про що не можна сказати про інші ліній нащадків родоначальників.

Таким чином, дослідженнями доведено, що притаманний високий генетичний потенціал м'ясної продуктивності молодняку гірській породи пінцгау при випасанні на полонинах із застосуванням методу підсису за прийнятою технологією м'ясного скотарства в умовах зони Карпат.

В результаті чистопорідного розведення породи пінцгау в господарствах різних фрормах власності гірської зони Карпат склалася така генеалогічна структура в 2015 році, яка наведена в таблиці 2.

Встановлено, що в господарствах з розведення пінцгау худоби, велика кількість, а саме 23 голів корів знаходиться від плідника Функера 357 лінії 3/8 ПЦ5/8, Сітейшина.

Таблиця 2

Генеалогічна структура маточного поголів'я

\begin{tabular}{|c|c|c|c|c|c|c|c|}
\hline \multirow{8}{*}{ Лінія } & \multirow{4}{*}{$\begin{array}{c}\text { Кличка } \\
\text { плідника та номер }\end{array}$} & \multicolumn{6}{|c|}{ Господарства } \\
\hline & & \multicolumn{2}{|c|}{$\begin{array}{c}\text { ПФГ } \\
\text { «Заріччя» }\end{array}$} & \multicolumn{2}{|c|}{$\begin{array}{c}\text { НВА } \\
\text { «Райдуга» }\end{array}$} & \multicolumn{2}{|c|}{$\begin{array}{c}\text { ФГ } \\
\text { «Поляківське» }\end{array}$} \\
\hline & & корів, гол. & $\begin{array}{l}\text { телиць, } \\
\text { гол. }\end{array}$ & $\begin{array}{l}\text { корів, } \\
\text { гол. }\end{array}$ & телиць, гол. & $\begin{array}{c}\text { корів, } \\
\text { гол. }\end{array}$ & $\begin{array}{c}\text { телиць, } \\
\text { гол. }\end{array}$ \\
\hline & & 8 & 6 & 5 & 3 & 2 & 1 \\
\hline & Функер 357 & 12 & 7 & 11 & 13 & 6 & 4 \\
\hline & Урал 747 & 11 & 7 & 4 & 2 & 3 & 1 \\
\hline & Жучок 35 & 7 & 4 & 6 & 5 & 4 & 2 \\
\hline & Всього & 38 & 24 & 26 & 23 & 15 & 9 \\
\hline
\end{tabular}

Оскільки, на перспективу планується в найближчий час використовувати сперму плідників Функера 357 та Урала 747 для зони розведення даної породи в Карпатському регіоні України. Як було зазначено вище, внутрішня структура пінцгау породи включає 4 - лінії, які використовують спадковий поліморфізм, що дасть на перспективу маркування кращого генетичного матеріалу.

Таким чином у зв'язку з цим оцінено ремонтні телиці та 122 корів породи пінцгау за фенотипом, генотипом та технологічними ознаками: жива маса бугайців кг у 7 місяців, середньодобові прирости - 700 - 800 г, молочність 160 - 180 кг в 210 днів. Перевірено за продуктивністю 2-х чистопородних бугаїв плідників синів лінії 3/8 ПЦ5/8, Сітейшина та $3 / 8 П Ц 5 / 820$ теж даної лінії голів в кількості 18 тварин за якістю нащадків за енергією росту - 800г у ФГ «Заріччя» Косівського району Івано-Франківської області. Вирощування молодняку породи пінцгау в гірській місцевості Карпат є необхідно за технологією м'ясного скотарства з використанням методу підсису, в результаті чого зростає енергія 
48 - Problems and prospects of implementation of innovative research results $\bullet$ Volume 2

росту до 862 г ФГ «Заріччя», що на 215 г (21,6\%) більше від ровесників, які вирощуються за технологією молочного скотарства.

\section{Список використаних джерел:}

1. Глазко, В.И., Столповский, Ю.А., Тарасюк, С.И., Букаров, Н.Г. \& Попов Н.А. (2008). Генетическая структура породы пинцгау в карпатском регионе. Генетика, Т.32, (5), 676682.

2. Мельник, Ю.Ф. (2009). Програма збереження генофоонду основних видів сільськогосподарських тварин в Україні на період до 2015 року (заг. наук. ред. І. В. Гузєва). К. : Арістей.

3. Гузєв, І. В. (2012). Методологія збереження біорізноманіття генетичних ресурсів тваринництва України (дис. ... доктора с.-г. Наук). Ін-т розведення і генетики тварин НААН]. Чубинське.

4. Про племінну справу у тваринництві (Закон України) (2004). за станом 20 лют. 2003 р., зі змінами від 29 чер. 2010 р., 19 жов. 2010 р. Нормативно-правові акти з питань племінної справи у тваринництві, Міністерство агарної політики України, ДНВК «Селекція». Київ.

5. Конвенція про збереження біологічного різноманіття ратифікована Законом України № 252/94-ВР від 29.11.1994 p. (1992). Вилучено з http://zakon4.rada.gov.ua/laws/show/995-030.

6. Кругляк, А. П. Актуальные вопросы сохранения генофоонда сельскохозяйственных животных. Быки производители локальных серой украинской и белоголовой украинской пород. . К. : Урожай, 1987, 3-8. 5.

7. Кругляк, А. П. (2007). Основні положення відбору популяцій тварин для тривалого зберігання їх генофонду. Проблеми збереження геносонду тварин : матеріали творчої дискусії 14 лютого 2007 р. К. : Аграрна наука, 49-53.

8. Програма збереження та раціонального використання генетичних ресурсів сільськогосподарських тварин на 2001-2005 роки (2001). Міністерство аграрної політики України. К.. Вилучено 3 http://www.uazakon.com/documents/date_2g/pg_itwhst.htm 243

9. Програма збереження генофонду основних видів сільськогосподарських тварин в Україні на період до 2015 року (заг. наук. ред. І. В. Гузєва, консультація та специфікація Ю. Ф. Мельника) (2009). К. : Арістей.

10. Програма збереження локальних та зникаючих порід сільськогосподарських тварин $в$ Україні (заідно з вимогами ФАО). (2013). Чубинське.

11. Criteria to assess the degree of endangerment of livestock breeds in Europe (2004). Production Science. V. 91, 173-182. 


\title{
SECTION III. \\ PUBLIC ADMINISTRATION AND ECOLOGY
}

\section{DOI 10.36074/13.12.2019.v2.02 \\ ПЕРСПЕКТИВИ ТА ПЕРЕВАГИ РЕЦИКЛІЗАЦІЇ БУДІВЕЛЬНИХ ВІДХОДІВ}

\begin{abstract}
Костюкова Марія Олександрівна
здобувач вищої освіти будівельного фракультету Придніпровська державна академія будівництва та архітектури

УКРАÏHA
\end{abstract}

Однією з найважливіших екологічних проблем в світі та Україні є проблема утилізації та рециклізації відходів. У зв'язку з високим рівнем приросту населення, зміною звичок споживачів, а також глобальними змінами клімату в останні десятиліття скорочення природних ресурсів стало великою загрозою для людства. Важливим питанням стало скорочення споживання матеріалу $\mathrm{i}$ збільшення ефективності його використання, завдяки якісній переробці.

Щорічно в Україні накопичується понад 350 мільйонів тонн відходів, лише $7 \%$ проходять подальшу переробку. За даними міжнародного агентства 24/7 Wall Street за 2018 рік Україна посіла 9 місце з 105 країн з найбільшим обсягом сміття на душу населення.

Будівництво - одна $з$ найважливіших сфер, в якій сировина $€$ найбільш споживаною. Крім цього, в будівництві виробляється приблизно $30 \%$ від загальної кількості відходів (в розрахунку на одну людину вони складають 30 кілограмів на день). Для їх мінімізації вкрай важливо скоротити споживання матеріалу i збільшити ефективність його використання, завдяки якісній переробці.

Характер відходів, що утворюються сильно розрізняється залежно від того, чи мова йде про знесення, реконструкції або нове будівництво, а також в залежності від географічного положення, віку і типології будівлі.

Відходи будівництва та знесення поділяють на 3 класи:

- небезпечні, які становлять особливу небезпеку для людей і / або навколишнього середовища (оброблена деревина, важкі метали, фрарби, розчинники);

- безпечні (дерево, картон, пластмаси, метали, штукатурка);

- інертні, зміст яких не схилен до ніяких фрізичних, хімічних або біологічних впливів (камені, матеріали для земляних робіт, цегла, скло). На них припадає близько $65 \%$ відходів. Вони можуть бути повторно використані безпосередньо на майданчику об'єкта або оброблені (дроблення, просіювання, очищення) для подальшого повторного використання в дорожніх роботах, включаючи тротуари і засипу.

Розподіл будівельних відходів:

$-70 \%$ виробляється під час знесення будівель і споруд;

$-20 \%$ займає реконструкція; 
-10\% виробляється безпосередньо на будівельних майданчиках;

Незважаючи на високий рівень забруднення, спричинений будівельними роботами, кожен будівельний майданчик вимагає комплексного плану управління відходами.

Економічні та екологічні вигоди, що досягаються за рахунок їх мінімізації, досягають досить значних обсягів, знижуючи витрати на будівництво і охорону навколишнього середовища.

Переваги переробки матеріалів:

1) Зниження впливу на навколишнє середовище: Використання металобрухту замість натуральних матеріалів забезпечує скорочення забруднення повітря на $86 \%$ і забруднення води на $76 \%$, а виробництво нової стали і нового чавуну рнегативно впливає не тільки на будівельну галузь, але й на населення. Та незважаючи на це проблема може бути легко вирішена шляхом вторинної переробки сталевого і залізного брухту. Крім того, це зведе до мінімуму вплив на навколишнє середовище, скорочуючи процеси видобутку при виробництві нових матеріалів і допоможе скоротити кількість викидів багатьох парникових газів.

2) Економія матеріалів: кількість постачання нових будівельних матеріалів може бути зменшено, оскільки більшість будівельних відходів придатні для повторного використання на майданчику.

3) Зниження кількості звалищ: оскільки велика частина будівельних відходів буде перероблятися, а відходи будівельної промисловості будуть в невеликій кількості, переробка вигідна для місць поховання відходів. Крім того, рециклізація знижує необхідність регулярного зберігання.

4) Створення додаткових робочих місць: переробка створює робочі місця i економічну діяльність в будівельному секторі, створює більше можливостей для найму, так як містить багато процесів, які повинні бути виконані робочою силою.

Недоліки переробки матеріалів:

1) Велика вартість: рециклізація не завжди вигідна. Створення нового підприємства вимагає великих капіталовкладень.

2) Місця переробки часто бувають негігієнічними і небезпечними.

3) Вироби з перероблених відходів часто не відповідають встановленим стандартам якості.

ВИСНОВОК: Хоча рециклізація грає важливу роль в зниженні рівня забруднення навколишнього середовища, на даний момент в Україні цей процес не набув широкого поширення і не був вдосконалений, на відміну від інших країн Європи, де близько 70\% відходів підлягають переробці. На жаль, переробка все ще вважається малою частиною для досягнення довгострокового успіху. Але після розуміння переваг і недоліків утилізації та рециклізації, беручи до уваги європейський досвід, ми можемо досягти великого прогресу в розвитку цієї технології на підприємствах і будівельних виробництвах нашої країни. Це допоможе значно збільшити рівень екологічного захисту навколишнього середовища, тим самим підвищивши рівень життя населення. 


\title{
ПРИНЦИПИ ПОБУДОВИ СТАЛОЇ СИСТЕМИ ПОВОДЖЕННЯ 3 ТВЕРДИМИ ПОБУТОВИМИ ВІДХОДАМИ В УКРАЇНІ
}

\author{
Корбут Марія Броніславівна \\ канд. техн. наук, доцент кафедри екології \\ Державний університет «Житомирська політехніка» \\ Герасимчук Олена Леонтіївна \\ канд. пед. наук, старший викладач кафедри екології \\ Державний університет «Житомирська політехніка»
}

УKPÄ̈HA

За даними Державної служби статистики України, щороку в країні утворюється близько 500 млн тонн відходів, у тому числі відходи первинного виробництва (76\%), відходи вторинного виробництва (близько 18\%), відходи сільського господарства (близько $2 \%$ ) та тверді побутові відходи (близько $2 \%$ ).

Проте, незважаючи на малу частку ТПВ у структурі відходів, ефективне функціонування цієї галузі має дуже велике значення, оскільки безпосередньо впливає на стан навколишнього середовища поблизу житлових районів. Окрім цього, перероблені відходи є додатковим джерелом сировини, матеріалів та енергії для національної економіки.

У 2000 році в Україні в середньому утворювалося 180 кг ТПВ на душу населення, у 2010-му цей показник збільшився до 270 кг, у 2019 році річна кількість відходів на душу населення становить близько 300 кг і має тенденцію до зростання.

Не дивлячись на те, що питомі показники утворення відходів в Україні все ще суттєво нижчі за середньоєвропейські (близько 503 кг на душу населення на рік) та нижчі за показники нових країн - членів ЄС (420 кг на душу населення), у 2017 році Україна потрапила на 9 місце рейтингу країн 3 найбільшим обсягом сміття на одного жителя за версією американського агентства 24/7 Wall Street [1].

Україна в рейтингу - країна з найбільшою кількістю населення після США 3 населенням. Сумарно за 2017 рік Україна виробила 474106025 тонн сміття. Велика частина інших 26 мільйонів тон відходів в Україні - це тверді побутові відходи і сільськогосподарські відходи, які включають в себе сміття, вироблене на фермах, птахофабрики і бійні, відходи збору врожаю, стоки добрив з полів і пестициди.

Структура ТПВ є вирішальним чинником для розвитку системи поводження з відходами. Тобто якісний склад відходів визначає вимоги до систем їх збору та утилізації, а також заходи, які мають застосовуватися в межах поводження з ТПВ. Роль цього показника суттєво зростає при необхідності вибору моделей переробки ТПВ. На жаль, до сьогодні в Україні не здійснювалися систематичні дослідження структури ТПВ. Єдиними джерелами статистичних даних можуть слугувати невеликі дослідження, які проводилися операторами ТПВ та відповідними асоціаціями в той чи інший час у тих чи інших регіонах. Ïх результати суттєво різняться між собою. Наприклад, згідно з дослідженнями, проведеними в межах національного проекту «Чисте місто», найбільші частки 
у структурі ТПВ припадають на продукти харчування (більше ніж $30 \%$ загального обсягу) та відходи упаковки, в основному картон і папір. За даними Шостого національного повідомлення України з питань зміни клімату, до структури ТПВ входять харчові відходи - 35-50\%, папір і картон - 10-15\%, вторинні полімери $-9-13 \%$, скло - 8-10\%, метали - 2\%, текстиль $-4-6 \%$, будівельні відходи - 5\%, деревина - 1\% та інші відходи - 10\% [2]. Розбіжності в даних, скоріше за все, пов'язані з обмеженим обсягом вибірки. Окрім того, можливо, що частину органічних відходів не було включено до оцінки.

У 2014 році Україна поставила собі за мету узгодити національне законодавство у сфрері поводження з твердими побутовими відходами 3 європейськими нормами. Заплановано імплементацію Директив $€ C$ 1999/31/EC та 2008/98/EC, які врегульовують поводження зі сміттям у країнах Європи, надають чітку послідовність дій, які необхідно виконувати із відходами, класифікують сміття, ставлять стратегічну мету скоротити кількість відходів, які вивозять на полігони [3].

Директива 1999/31/ЄС про захоронення відходів встановлює процедури прийняття відходів на полігони для захоронення, а також врахування всіх витрат у розмірах плати за захоронення відходів, процедури моніторингу та контролю офіційно створених полігонів, проведення їх технічної оцінки та розроблення планів приведення у відповідність вимогам Директиви та ін. До її ключових положень належать: встановлення класів місць захоронення відходів (МЗВ), встановлення типів відходів, що дозволені для захоронення на відповідних класах полігонів, а також категорії відходів, що не дозволені для захоронення, розроблення та прийняття національної стратегії для зменшення кількості захоронення відходів, що біологічно розкладаються, умови та зміст документів на отримання дозволу та фінансову відповідальність оператора.

Основними проблемними питаннями з реалізації Директиви 1999/31/ЄС про захоронення відходів на сьогодні $є$ :

- розроблення процедур та проведення ідентифрікації і класифікації полігонів;

- технічна оцінка існуючих полігонів;

- процедура закриття полігонів;

- приведення у відповідність до екологічних стандартів об'єктів полігонного захоронення відходів.

Труднощі пов'язані із віднесенням наявних полігонів до тих чи інших категорій за новою класифрікацією, впровадженням фінансових гарантій при отриманні дозволу, з врахуванням у вартості захоронення відходів витрат на закриття полігонів та наступного догляду, впровадженням стратегії скорочення захоронення відходів, що біологічно розкладаються (оскільки в Україні практично відсутня відповідна інфрраструктура).

Директива 2008/98/€С про відходи та скасування деяких Директив, встановлює загальні принципи, процедури і вимоги, а також ключові поняття у сфері поводження з відходами, до її ключових положень належать: ієрархія відходів - принципи мінімізації, цілі та пріоритети політики, список відходів (List of waste) - як класифікаційна основа. $€$ обов'язковим по відношенню до визначення відходів як небезпечних. Він покликаний забезпечити узгодження класифікації відходів в рамках $Є С$, управління відходами - акценти зроблено на відповідальності за управління, на впровадженні принципів самодостатності та наближення, а також на забороні змішування небезпечних 
відходів, побічні Продукти - умови і критерії визначення відходів як побічного продукту, кінець статусу відходів - умови і ознаки за якими відходи перестають ними бути.

До основних проблемних питань з реалізації Директиви належать:

- узгодження класифікації відходів. Імплементація Європейського переліку відходів (List of waste) пов'язана з одними із найбільш значних реформацій в нормативно-правовому полі України щодо відходів. Перехід на європейські стандарти має відбутися за максимального збереження позитивного вітчизняного досвіду;

- перехід від розробки державних програм поводження з відходами з їх низьким рівнем відповідальності за виконання до розроблення планів 3 управління відходами 3 наднаціональним рівнем звітності і контролю виконання;

- запровадження розширеної відповідальності виробника при створенні систем поводження 3 відходами упаковки, відпрацьованими мастилами (оливами), шинами, батарейками i акумуляторами, електронними i електричними відходами тощо;

- реалізація принципів самодостатності та наближення при управлінні відходами та при стратегічному плануванні поводження з ними в регіонах та на державному рівні.

Одним з результатів впровадження Директив є те, що з 1 січня 2018 року Україна зобов'язалася сортувати все сміття за видами матеріалів, а також розділяти його на придатне для повторного використання, для захоронення та небезпечне. Про це йдеться у статті 32 Закону України "Про відходи", до якої був доданий відповідний пункт ще у 2012 році [4].

Використовуючи принцип сходів Лансінка (рис.1): принципи і методи управління відходами, визначені голландським парламентарієм - Едом Лансінком. Сходинки являють собою ієрархію все кращих шляхів роботи 3 викидами відповідальним по відношенню до навколишнього середовища чином та спираючись на досвід країн ЄС у сфері поводження з ТПВ, можна запропонувати низку рішень, які могли би бути ефективними в Україні, яка поставила собі за мету узгодити національне законодавство у сфері поводження з відходами з європейськими нормами. Саме тому застосування запропонованого підходу до моделювання розвитку галузі поводження з ТПВ в Україні $є$ обґрунтованим.

Загалом зазначена модель базується на дотриманні трьох основних принципів політики $Є С$ у галузі поводження з ТПВ:

1) забезпечення екологічної безпеки відповідно до стандартів (вимог) протягом усього життєвого циклу ТПВ;

2) визначення пріоритетів відповідно до наведеної вище ієрархії методів поводження з відходами;

3) повномасштабне впровадження принципу «забруднювач платить» за двома напрямами:

- принцип розширеної відповідальності виробника - виробник платить;

- суб'єкти, які утилізують сміття (домогосподарства та організації), повністю сплачують за найбільш екологічно безпечний спосіб його переробки й утилізації. 


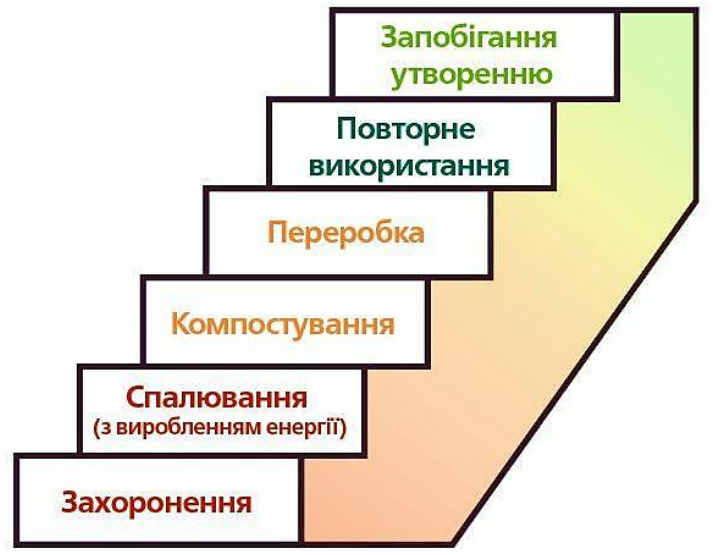

\section{Рис.1 Сходи Лансінка (Eurowaste, Types of waste, 2014 рік)}

Висновки. Аналізу перспектив імплементації Директив 2008/98/€С та 1999/31/ЄС в українське законодавство, принципів політики ЄС у галузі поводження з ТПВ та можливості застосування європейського досвіду в моделюванні динаміки обсягу та структури відходів в Україні, дозволив зробити висновок, що мінімізація впливу відходів на навколишнє середовище $€$ найважливішим принципом побудови сталої системи поводження з ТПВ.

\section{1. Електроний \\ Список використаних джерел:}

https://www.usatoday.com/story/money/2019/07/12/canada-united- states-worlds-biggestproducers-of-waste/39534923/

2. Національна стратегія поводження з твердими побутовими відходами в Україні: звіт про існуючу ситуацію в секторі та стратегічні питання. (2004). Данське екологічне співробітництво з країнами Східної Європи (DANCEE), Мін-во навколишнього середовища (Данія), Держ. ком. України з питань житлово-комунального господарства. К. № 59219 R1.

3. Проект Європейського Союзу «Додаткова підтримка Міністерства екології та природних ресурсів України у впровадженні Секторальної бюджетної підтримки».(2013). Інституціональний розвиток сфери поводження з відходами в Україні: на шляху Європейської інтеграції / В. С. Міщенко, Ю. М. Маковецька, Т. Л. Омельяненко. К.: Ін-т економіки природокористування та сталого розвитку НАН України.

4. «Про відходи (Закон України). № 187/98-ВР (1998). 


\title{
SECTION IV. \\ ENGINEERING AND IT
}

\section{DOI 10.36074/13.12.2019.v2.04 \\ ASPECTS OF LIGHTNING NETWORK PAYMENT PROTOCOL IMPLEMENTATION}

\author{
Andrii Vlasov \\ $\mathrm{PhD}$ in Engineering, Leading Researcher of Air Force Science Center \\ Kharkiv National University of the Air Force
}

UKRAINE

Lightning Network (LN) is a technology that allows you to transform any crypto currency into a fast and reliable payment instrument with minimal fees. The active phase of technology testing and launching began only at the end of 2017. The LN is used to make payments in bitcoin (or other crypto currencies) with small volumes and offload the core network. Thanks to its use of technology, the number of transactions per second can increase hundreds of thousands of times, and the commission for the transfer will be reduced to the minimum values or at all will be equal to zero.

A typical bitcoin transaction is as follows: the sender wants to transfer a certain amount to the BTC recipient and he or she has to pay a considerable fee that goes to another network participant as a reward for including the transaction in the block. The transaction is in the queue - the sender and the recipient wait for it to be written to the block and only then receive the final result. All these are side effects of the small block size (only $1 \mathrm{MB}$ for Bitcoin network) and the huge number of transactions in the queue [1].

LN solves this problem by using so-called "payment channels". The technology allows you to set up separate networks between two participants in the core network, whose internal transactions will not be recorded in the blockchain, but only stored within the channel network. This means that users can make as many transactions as they want without downloading the main network [1]. When working on such a scheme, only the fact of opening and closing the channel with the specified beginning and ending balance of the parties is recorded in the blockchain, and all transactions that have passed through the channel do not take place in the blockchain. This network works not only with two participants and scales to any size, combining senders and recipients with a chain into one channel, choosing the best route. The peculiarity of this operation is that the network does not send funds through the channels, but only information about their possession, that is, the aforementioned receipt, because to open the channel requires a deposit by the parties.

The Network is a peer-to-peer micro transaction payment network that supports crypto currencies such as Bitcoin, Ethereum, Litecoin. The objective of this network is to accelerate crypto currency payments without delegating the right to own money to a third party, as well as to combine different crypto currencies into a single network with border points in the form of decentralized exchanges.

Two elements of a peer-to-peer network are a node and a connection: 
- a node in the LN may be understood to be a mobile application/desktop program server software that supports a specific protocol (LN), such as Go language implementation;

- the connection to the LN means the created payment channels, as the relationship between the participants, which is registered in the blockchain and regulated by a smart contract.

Each node has the ability to accept and send payments, as well as act as a payment provider, receiving a commission for this. It is only possible to send payment from one participant to another if there is a path consisting of payment channels connecting the recipient and the sender. By taking a payment commission, the network encourages the creation of nodes that connect many other users. Exchanges and wallets, as well as other organizations that will build their services on the basis of this technology, may serve as such nodes in the future.

The difference between LN and Visa and MasterCard networks is that anyone can join it. "Openness" is achieved through the use of smart contracts. LNs have built-in algorithms similar to TOR networks, so the payee and sender are not known to the nodes. In the future, the LN can be applied to any blockchain that implements basic multi-signature transactions, timestamps and major smart contracts. When applied to the top of the Bitcoin network, the LN can significantly increase capacity, privacy, granularity and speed without sacrificing the principles of trusted transactions without intermediaries.

The main benefits of LN implementation are increasing privacy, variability, speed and power. LN payments are much more private than Bitcoin blockchain payments because they are not publicly available. Route members can see payments distributed through their channels, but they do not know the sender or recipient. In the $L N$, it is much more difficult to monitor and blacklist the bitcoins. Transactions using the LN are executed in milliseconds, not minutes, as HTLCs are cleared without making transactions to the block. This increases the capacity of the bitcoin system by several orders of magnitude. There is virtually no upper limit to the number of payments per second, as it depends only on the power and speed of each node.

The $L N$ protocol is not the only way to implement routed payment channels. Other systems include Tumblebit and Teechan. However, by this time the LN has already been rolled out, several different teams have developed competing prototypes and are working on a single standard of compatibility (called BOLT). The concept of the Bitcoin platform puts a limit on the number of transactions per second, so increasing system throughput through blockchain reduces the effectiveness of the principles of decentralized crypto currency management. The developers applied several different schemes to solve this problem, which led to the creation of Bitcoin Cash fork and blockchain division, and Bitcoin itself began to use scaling through the LN.

Thus, by its functionality, Lightning Network technology is a development focused on increasing bitcoin network bandwidths while achieving the required frequency of operations (at the level of Visa network indicators), but at the same time increasing the performance, availability and speed of information processing (transaction execution) [2].

\section{References:}

1. Joseph Poon, Thaddeus Dryja (2016). The Bitcoin Lightning Network: Scalable Off-Chain Instant 
Payments. Retrieved from https://lightning.network/lightning-network-paper.pdf

2. Don Tapscott, Alex Tapscott (2016). Blockchain Revolution: How the Technology Behind Bitcoin is Changing Money, Business, and the World. New York: Portfolio / Penguin, p.369.

DOI 10.36074/13.12.2019.v2.05

\section{IMPROVEMENT OF METHOD, MODEL OF ARCHITECTURALLY INDEPENDENT HARDWARE PLATFORMS}

\begin{abstract}
Дуда Любомир Тарасович
аспірант кафедри робототехніки та спеціалізованих комп'ютерних систем

Черкаський державний технологічний університет

Вознюк Юрій Іванович

аспірант кафедри робототехніки та спеціалізованих комп'ютерних систем

Черкаський державний технологічний університет
\end{abstract}

НАУКОВИЙ КЕРІВНИК:

Корпань Ярослав Васильович

канд. техн. наук, доцент

Черкаський державний технологічний університет

УКPAÏHA

Smart home technologies and energy-saving technologies are nowadays one of the key directions of the country's energy policy development in all spheres of economy. The relevance of the topic is also due to the need to save money on paying for energy resources. Increasingly, users want to control remote objects in their absence [1].

Nowadays, there are many different modules on the market, ranging from the simplest and cheapest and to complex individual systems. Smart home systems have long ceased to be a luxury item, and can even be assembled by a person without some technical knowledge and skills.

The Internet offers a large number of ready-made circuits and solutions for managing any device or system in the home. Enthusiasts upload even self-written software to the network and you only have to download the application code to your device, following the detailed developer instructions. Although the market is crowded with various modules, platforms and systems, the problem of optimizing them remains relevant for both scientists and ordinary users.

The main parameters for such modules are the compactness of the scheme, the minimization of the consumed energy scheme and its cost. You can use a readymade scheme "out of the box", or you can independently assemble the desired system. The ready-made schemes have their advantages [2]:

— proven technology, reliability;

- system warranty and ongoing software updates;

- ready-made modules that are able to solve the main problems.

- The disadvantage of ready-made systems is:

- high price;

- usually not much flexibility of configuration and limited capacity of the control module; 
- closed technology or / or protocols and / or circuitry.

- The benefits of self-assembled smart home devices are:

- building systems on open standards, technologies, protocols;

- availability of electronic components for repair;

- ability to optimize software for their needs;

- ability to scale the system and add new features;

- In turn, the self-assembled scheme also has its disadvantages:

- lack or insufficient ability to connect to other home systems;

- lack of ready-made modules and the need to select components;

- lack of technical support;

- uncertain reliability and need for testing.

Chinese manufacturers are now offering many modules designed for the Arduino platform. The Arduino Nano is a reasonably priced and compact platform with prices ranging from $\$ 2$ to $\$ 4$. You need only a few modules to build the simplest smart device. It will always be more convenient for the average user to buy a ready-made device, but designing a smart home can be a good hobby and a foundation for the development of the electronics world.

\section{Home automation. Wikipedia Online Encyclopedia. Retrieved from: https://en.wikipedia.org/wiki/Home_automation}

2. Allen Dominus. Advantages and disadvantages of smart home. Retrieved from: https://www.criticthoughts.com/guides/advantages-and-disadvantages-of-smart-home/

\section{АНАЛІЗ СПОСОБІВ ЗМЕНШЕННЯ ВПЛИВУ ЗНОСУ ТА ТОЧНОСТІ ВИГОТОВЛЕННЯ ДВООПОРНИХ ЗАМКОВИХ РІЗЬБОВИХ З'ЄДНАНЬ ОБВАЖНЕНИХ БУРИЛЬНИХ ТРУБ}

НАУКОВО-ДОСЛІДНА ГРУПА:

Михайлюк Василь Володимирович

доцент кафедри нафтогазових машин та обладнання Івано-Франківський національний технічний університет нафрти і газу

Фафлей Олег Ярославович

асистент кафедри будівництва та енергоефективних споруд Івано-Франківський національний технічний університет нафтти і газу

Дейнега Руслан Олександрович

асистент кафедри нафтогазових машин та обладнання Івано-Франківський національний технічний університет нафрти і газу 
December 13, $2019 \bullet$ Valletta, Republic of Malta $\bullet 59$

Семенчук Андрій Васильович

доцент кафедри прикладної математики Івано-Франківський національний технічний університет нафрти і газу

УКРАÏHA

Спорудження глибоких похило-скерованих та горизонтальних свердловин на нафртогазових родовищах призвело до необхідності створення та використання якісно нового високотехнологічного бурового обладнання. Насамперед це стосується елементів компоновки бурильної колони, які у найскладніших умовах експлуатації повинні витримувати підвищені навантаження на кручення, згин та розтяг. Існуючі труби виготовлені згідно API не можуть витримувати таких навантажень.

Ці навантаження на бурильну колону збільшуються у декілька разів в умовах високих тисків та температур, тим самим вимагаючи додаткового запасу міцності обладнання та максимальної надійності різьбових з'єднань бурильних труб та обважнених бурильних труб (ОБТ).

Більш того, у зв'язку із високою вартістю бурових робіт, нафртогазові компанії та бурові підрядники надають все більше значення зниженню експлуатаційних та інших ризиків під час спорудження свердловин та максимальному скороченню виробничих витрат. Останнє є неможливим без використання високонадійного обладнання разом із оптимізацією програм спорудження свердловин.

Ефективність спорудження свердловин у основному пов'язана із збільшенням швидкості проходки та зменшенням непродуктивного часу. Цієї мети можна досягнути при грамотному підході до конструкції та компоновки бурильної колони на етапі проектування, приймаючи до уваги наступні фактори:

- зовнішній та внутрішній форми бурильних труб та замкових з'єднань не повинні створювати великого гідравлічного опору при русі бурового розчину);

- механічні характеристики тіла труби, зварних швів та різьбових з'єднань мають бути достатньо високими, щоб витримувати навантаження від дії моментів згвинчування, згинних, розтягуючих та крутних навантажень;

- інші особливості конструкції бурильних труб (внутрішня висадка, відстань "під ключ" тощо), що впливають на втомну міцність металу, можливість додаткового ремонту [1].

У стандартній конструкції бурильних труб та обважнених бурильних труб (ОБТ) слабким місцем є замок (різьбове з'єднання). Відомо, що ефективність замка (відношення навантаження на кручення, що витримує бурильна труба до навантаження на кручення, що витримує бурильний замок) становить близько 80 - 90\% [2]. 3 метою збільшення цього показника, а також для підвищення ефективності роботи при одночасному крученні, розтягу та згину (тобто при найбільш характерних навантаженнях, що виникають у випадку аварійних ситуацій під час буріння) сьогодні у світовій практиці застосовують двоопорні замкові з'єднання (рис. 1) [3-5]. 


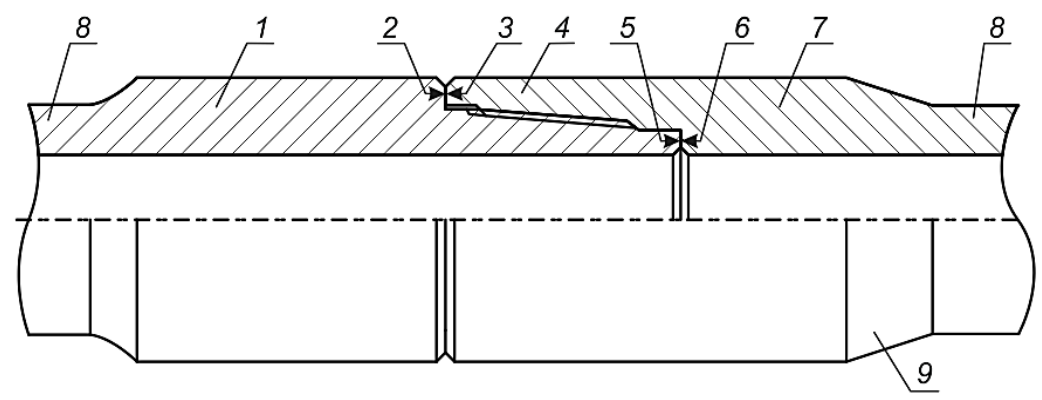

Рис. 1. Схема двоопорного замкового з'єднання

1 - ніпель; 2 - опорний уступ ніпеля; 3 - опорний торець муфрти;

4 - замкова різьба; 5 - опорний торець ніпеля; 6 - опорний уступ муфрти;

7 - муфрта; 8-хвостовики ніпеля і муфрти; 9 - конічний заплечник під елеватор

Двоопорна конструкція з'єднання містить основну зовнішню опору (складається із опорного уступа ніпеля 2 та опорного торця муфрти 3), що служить поверхнею ущільнення з'єднання, і додаткову внутрішню опору (складається 3 опорного уступа муфти 6 та опорного торця ніпеля 5), що $€$ механічним обмежувачем і поверхнею тертя, яка забезпечує додатковий опір прикладеному крутному та згинному моментам. Конструкції таких з'єднань мають різьбу як і стандартні з'єднання згідно American Petroleum Institute (API).

Для конструкції двоопорних замків ОБТ можна виокремити наступні їх переваги порівняно із стандартними замками згідно API:

- передача більшого крутного моменту (навіть у 1,5 рази) та більша стійкість до дії згинального моменту;

- запобігання заклинюванню замків при максимальних моментах кручення;

- вища втомна міцність;

- в поєднанні 3 високоміцними трубами дозволяють споруджувати свердловини із складним профрілем і високою інтенсивністю набору кривизни;

- дозволяють значно підвищити гідравлічні характеристики (мають рівнопрохідний внутрішній діаметр, що обумовлює більш плавний потік промивальної рідини, зниження турбулентності, виключення можливості схоплення твердих частин бурового розчину всередині замка);

- взаємозамінність із стандартними бурильними замками;

- більший допуск по зносу зовнішньої поверхні замка.

Розробленню та дослідженню двоопорних різьбових з'єднань ОБТ присвячено праці [6-8].

Проте для таких з'єднань важливим $є$ забезпечення надійного контакту та задані навантаження одночасно по трьох поверхнях: по конічній різьбі, основному та додатковому опорних торцях. Це зробити практично досить складно, незважаючи на жорсткий допуск, що задається на відстань між основним та додатковим опорними торцями та опорними уступами ніпеля та муфрти різьбового з'єднання.

У результаті один із опорних торців може бути недовантаженим, а інший навпаки - перевантаженим. Особливу небезпеку становить випадок, коли 
через незначні відхилення від заданих допусків, недовантаженим або навіть відкритим виявляється основний опорний торець. В результаті це може призвести до пришвидшення втомного руйнування різьби, і як наслідок, до обриву і відповідно аварії бурильної колони.

Лабораторні дослідження на втому при знакозмінному консольному згині натурних взірців бурильних труб ССК-59 з такими з'єднаннями свідчать, що залежно від точності їх виготовлення, циклічна довговічність з'єднання може відрізнятися на порядок [9].

Отже, необхідно створити таке різьбове з'єднання, у якому задане навантаження на додатковий опорний торець забезпечується при виготовленні та підтримується у процесі всього періоду його функціонування і не обумовлене жорстким допуском на відстань між опорними торцями та упорними уступами з'єднувальних деталей, а також їх зносом.

Для вирішення цієї задачі може бути використано різьбове з'єднання труб [10] (рис. 2) із додатковою опорою торця ніпеля і муфрти, особливістю якої є її виконання з двох контактних площин 5 та 6 під кутом.

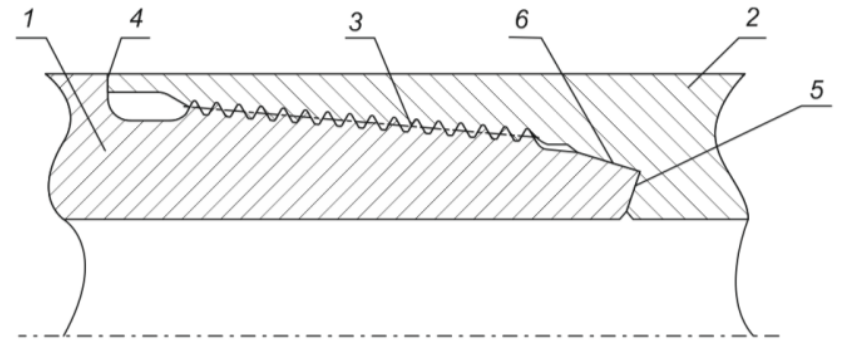

\section{Рис. 2. Різьбове з'єднання для сталевих труб з додатковою опорою торця ніпеля та муфти \\ 1 - ніпель; 2 - муфрта; 3 - з'єднання різьби; 4 - основна опора; \\ 5 - перша площина додаткової опори; 6 - друга площина додаткової опори}

Окрім того, що згідно [10] дане з'єднання має більшу герметичність порівняно із одноопорним, та залежно від кутів, що утворюють першу та другу площини додаткової опори можна в певних межах компенсувати пружними деформаціями неточності виготовлення з'єднання. Але при цьому виникає недолік - значна концентрацію напружень у зоні додаткового опорного торця, що, у свою чергу, призведе до зменшення терміну його експлуатації.

Також для вирішення цієї задачі у [9] описано конструкцію різьбового з'єднання бурильного замка (рис. 3), що складається із ніпеля 1, муфти 2 та прорізної пружини 5, яка встановлена між опорним уступом 3 муфтти і опорним торцем 4 ніпеля. При цьому між опорним уступом 6 ніпеля і опорним торцем 7 муфти утворюється зазор $\mathrm{h}$, який ліквідується в процесі затягування з'єднання і стиснення пружини. Величина зазору $\mathrm{h}$ дорівнює ходу пружини ho та згідно 3 iї параметрами, строго відповідає заданому осьовому навантаженню на внутрішній опорний стик. Завдяки цьому, після затягування з'єднання, забезпечується також строго задане осьове навантаження на зовнішній 
опорний стик, як різниця між загальною силою затягування різьбового з'єднання і силою, створюваною пружиною на внутрішній опорний стик.

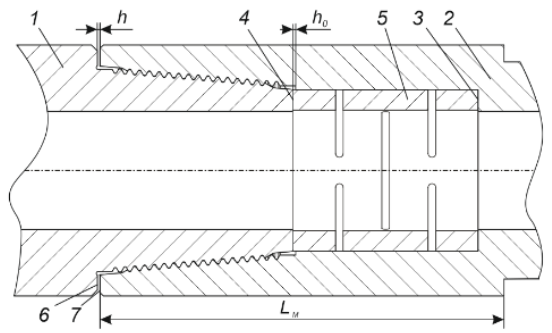

a)

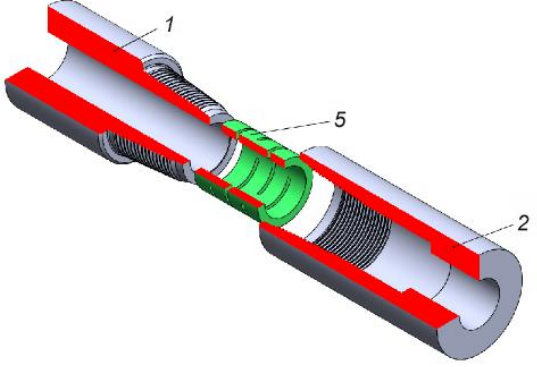

б)

\section{Рис. 3. Різьбове з'єднання бурильного замка із встановленою всередині прорізною пружиною}

1 - ніпель, 2 - муфтта, 3 - опорний уступ муфти, 4 - опорний торець ніпеля,

5 - прорізна пружина; 6 - опорний уступ ніпеля, 7 - опорний торець муфти

а - схема; б - тривимірна модель

Встановлена в різьбовому з'єднанні бурильних труб між опорним уступом муфти і опорним торцем ніпеля прорізна пружина має параметри, що забезпечують при її стисненні на величину ходу $h=h_{0}$, задану осьову силу на внутрішній опорний стик.

В процесі багаторазового збирання-розбирання з'єднання під час спускопідйомних операцій точно задана відстань між опорними торцями порушується через зношування їх поверхонь, що призводить до суттєвих змін заданих співвідношень осьових сил на обох опорних стиках і зниження функціональних можливостей різьбового з'єднання.

У різьбовому з'єднанні бурильних труб при застосуванні прорізної пружини, деформація якої на порядок вище, ніж у матеріалу деталей з'єднання, вимоги до точності відстані між опорними стиками різко знижуються, а знос опорних поверхонь не чинить істотного впливу на задану осьову силу затяжки з'єднання на внутрішній стик, так як його величина також на порядок менше ходу пружини.

Отже, згідно [9], прорізна пружина в конструкції різьбового з'єднання бурильних труб забезпечує створення строго заданих осьових навантажень на внутрішній та зовнішній опорні стики і збереження їх співвідношення на весь період експлуатації, оскільки практично не залежить від допуску на відстань між ними і від зносу їх опорних поверхонь.

Проте окрім переваг при застосуванні прорізної пружини у конструкції різьбового з'єднання, є ще і недоліки:

- великі габаритні розміри;

- значна концентрація напружень у елементах пружини;

- потрапляння у прорізи пружин вибуреної гірської породи.

Для отримання аналогічного ефекту, як і при застосуванні прорізної пружини та ліквідації вище перелічених її недоліків пропонується використання 
у конструкції двоопорних замкових різьбових з'єднань ОБТ пружних елементів (кільцевих пружин), рис. 4.

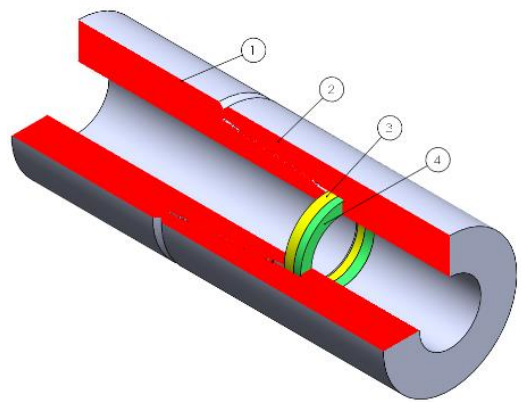

a)

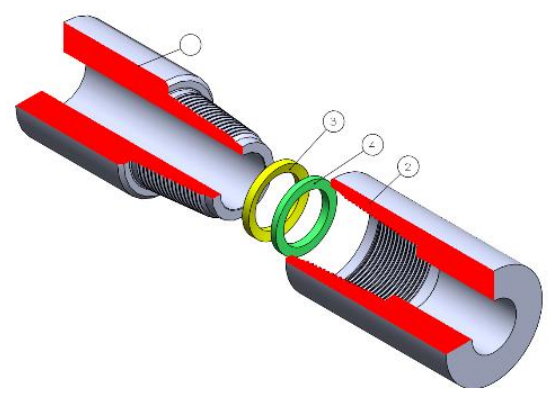

б)

Рис. 4. Тривимірна модель двоопорного різьбового з'єднання із встановленим пружнім елементом

1- ніпель; 2 - муфрта; 3, 4-пружні елементи

Отже, для зменшення впливу зносу та точності виготовлення двоопорного замкового різьбового з'єднання бурильних за рахунок використання кільцевих пружин в подальшому необхідно визначити їх параметри для забезпечення строго заданих осьових навантажень на внутрішній та зовнішній опорні стики $\mathrm{i}$ збереження їх співвідношення на весь період експлуатації.

\section{Список використаних джерел:}

1. Бурильні труби. Вилучено з http://naukarus.com/povyshenie-proizvoditelnosti-bureniya-zaschet-ispolzovaniya-burilnyh-trub-s-rezbovymi-soedineniyami-vam

2. Билан, С.И., Быков, П. А. \& Емельянов, А. В. (2010). Бурильные трубы: без права на разрыв. Бурение и нефть, (9), 38-39.

3. Каталог труб и услуг по трубной продукции компании DRILCO. Изїято из http://www.tubular.nssmc.com/ru/product-services/octg/connection/list

4. Каталог продукции компании NOV® GrantPrideco.

5. Артим, В.І., Фафлей, О.Я., Дейнега, Р.О. \& Михайлюк, В. В. (2017). Дослідження впливу конструктивних елементів двоопорних замкових з'єднань бурильних труб на їх напружено-деформований стан. Розвідка та розробка нафт. і газ. родовищ,№ 4(65), 77-87.

6. Артим, В.І., Фафллей, О.Я., Дейнега, Р.О. \& Михайлюк, В. В. (2017). Аналіз сучасних конструкцій замкових з'єднань обважнених бурильних труб Нафтогаз. Енергетика, ( 2(28)), 22-30.

7. Артим, В.І., Фафолей, О.Я., Михайлюк, В.В \& Дейнега, Р.О. (2017). Дослідження напруженодеформованого стану двоопорних замкових з'єднань бурильних труб. Молодий вчений.№11 (51), 1043-1047

8. Лачинян, Л. А. Резьбовое соединение бурильных труб : патент RU 2521123 C2 Российская Федерация : МПК (2006.01) Е21В 17/042( патентообладатель: ОАО «Завод бурового оборудования»). № 2012 121505/03; заявл. 25.05.2012; опубл. 27.11.2013. Бюл. № 33.

9. Пат. 2934937 Российская Федерация, МПК F16L 15/04. Резьбовое соединение для стальных труб ( Кеита Иносе, Фумио Ота, Син Угаи, Масааки Сугино) № 2016131299, заявл. JP 2015/000076 (09.01.2015), опубл. 25.09.2017 Бюл. № 27. 


\section{ВПЛИВ ВИКОНАННЯ ТЕХНОЛОГІЧНИХ ОПЕРАЦІЙ В ПРОЦЕСІ БУРІННЯ СВРДЛОВИН НА ЗМІНУ ВИБІЙНОГО ТИСКУ}

\section{НАУКОВО-ДОСЛІДНА ГРУПА:}

Лях Михайло Михайлович

канд. техн. наук, професор, професор, кафедри нафтогазових машин та обладнання Івано-Франківський національний технічний університет нафрти і газ

Концур Іван Федорович канд. техн. наук, доцент, доцент, кафедри нафтогазових машин та обладнання Івано-Франківський національний технічний університет нафоти і газ

Михайлюк Василь Володимирович канд. техн. наук, доцент, доцент, кафедри нафтогазових машин та обладнання Івано-Франківський національний технічний університет нафрти і газ

Дейнега Руслан Олександрович асистент, кафедри нафтогазових машин та обладнання Івано-Франківський національний технічний університет нафоти і газ

Клицюк Василь Олегович здобувач вищої освіти інституту інженерної механіки Івано-Франківський національний технічний університет нафрти і газ

УКРӒ̈̈А

Спуско-підіймальні операції є невід'ємною технологічною складовою в процесі буріння свердловин, що суттєво впливає на зміну вибійного тиску.

При виконанні спуско-підіймальних операцій рівень розчину постійно змінюється. При підніманні трубної колони із свердловини рівень промивальної рідини знижується, а при спуску - промивальна рідина витісняється (на величину об'єму матеріалу труб). Тому контроль за рівнем розчину в свердловині є надзвичайно важлива і актуальна задача.

Важливим чинником попередження газонафтопроявлень $€$ контроль за рівнем бурового розчину у свердловині, а відповідно тиску на вибої в процесі виконання спуско-підіймальних операцій. При підніманні бурильної колони у свердловину необхідно доливати і водночас контролювати відповідність об'єму долитого бурового розчину об'єму металу піднятих труб. Як засвідчує вітчизняна та зарубіжна практика бурових робіт з підніманням бурильної колони пов'язано більше 50\% аварійних викидів. Тому питання підвищення якості контролю за рівнем бурового розчину в свердловині та своєчасним доливанням $€$ досить важливим.

Так як густина бурового розчину в інтервалах сумісних умов буріння повинна визначатися з розрахунку створення стовпом бурового розчину гідростатичного тиску в свердловині.

Максимально допустима репресія повинна унеможливлювати гідророзрив або поглинання бурового розчину на будь-якій глибині інтервалу сумісних умов буріння. 
На рисунках 1а, та $1 б$ зображені варіанти схем доливу бурового розчину в процесі підйому бурильних колони.

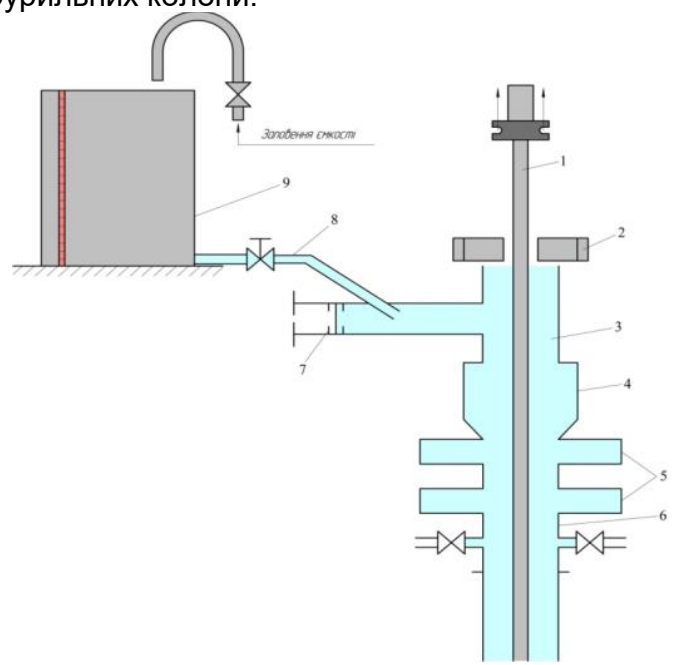

Рис. 1. Схема доливання свердловини самопливом під час підіймання бурильної колони

1-бурильна колона; 2-ротор; 3-зливний жолоб; 4-універсальний превентор; 5плашкові превентори; 6-підпревенторна хрестовина; 7-шибер; 8-лінія доливу; 9 доливна ємкість.

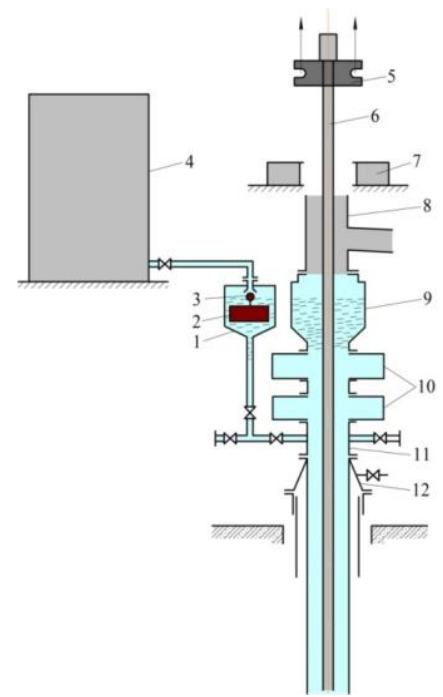

Рис. 2. Система автоматичного доливу свердловини під час підіймання бурильної колони

1 - дозувальна ємкість; 2 - поплавок; 3 - клапан; 4 - доливна ємкість; 5-елеватор; 
66 - Problems and prospects of implementation of innovative research results $\bullet$ Volume 2

6 - колона труб; 7 - ротор; 8 - зливний жолоб; 9 - уніварсальний превентор; 10 плашкові превентори; 11 - хрестовина; 12 - колонна головка.

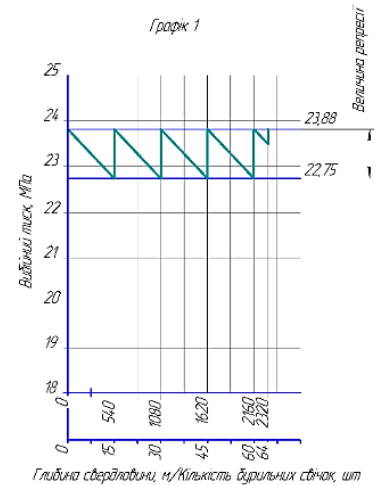

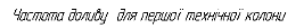
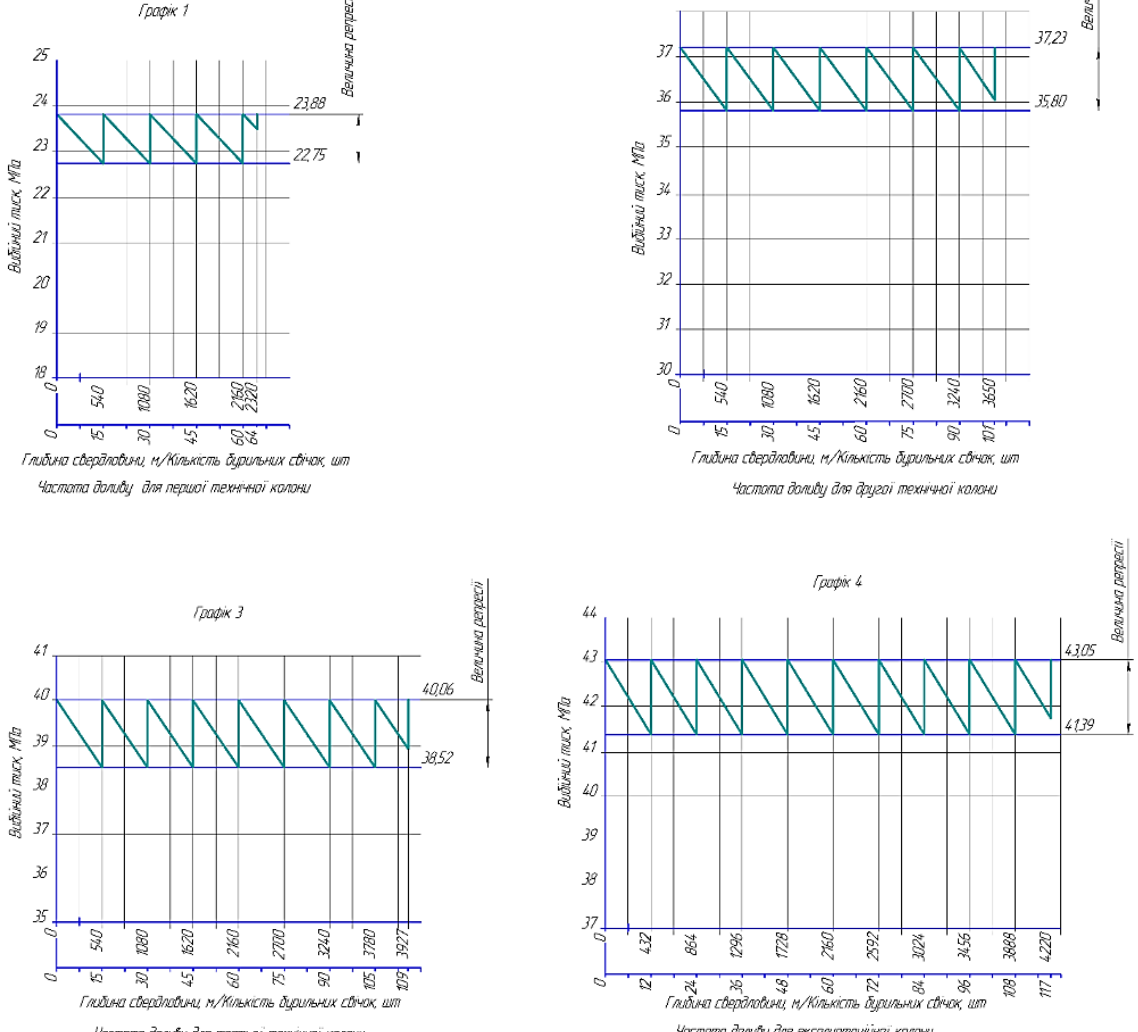

Рис. 3. Графіки доливу

На рисунку 3 наведено приклад графіків доливу свердловини в процесі підйому бурильної колони під час буріння першої технічної колони діаметром 324 мм з товщиною стінки 9,5 мм, другої технічної колони діаметром 245 мм товщиною стінки 8,9 мм, третьої технічної колони 194 мм товщиною стінки 9,5 мм та під експлуатаційну колону діаметром 168 мм і товщиною стінки 7 мм.

Висновки

На графіках видно допустиму зміну вибійного тиску та частоти доливу 3 врахування кількості піднятих свічок.

Доречно зауважити що доливання відбувається при підйомі максимум 15 свічок (свічка, це дві-три бурильні труби) для підвищення фонтанної безпеки.

Для попередження газонафртопроявлення важливим $€$ контроль рівня бурового розчину у свердловині під час проведення спуско-підйомних операцій. 
Для забезпечення нормальних умов процесу виконання спускопідіймальних операцій.

Системи доливу свердловин необхідно оснастки засобами контролю рівня рідини в заданих межах та контрольованим об'ємом.

\title{
Список використаних джерел:
}

1. Костриба І., \& Клицюк В. (2018). Про контроль рівня бурового розчину в свердловині в процесі піднімання трубної колони. II Міжнародна науково-технічна конференція «Машини, обладнання і матеріали для нарощування вітчизняного видобутку нафти і газу PGE - 2018» (158-161), 2018, Івано-Франківськ, Україна.

2. Лях, М., Концур, І., Михайлюк, В., Дейнега, Р., \& Канівець, М. (2019). Аналіз технічних засобів для буріння свердловин із заданим вибійним тиском. ^'ОГОГ. Мистецтво наукової думки, (5), 39-43. вилучено із https://ojs.ukrlogos.in.ua/index.php/2617-7064/article/view/28

\section{ДОСЛІДЖЕННЯ СИНТЕЗОВАНИХ ТЕРМОПЕРЕВОДНИХ ОРГАНІЧНИХ БАРВНИКІВ I IX ВИКОРИСТАННЯ}

\author{
НАУКОВО-ДОСЛІДНА ГРУПА: \\ Вигоняйло Олександр Іванович
}

здобувач наукового ступеня, канд. техн. наук на кафедрі екології і полімерів Iнститут хімічних технологій (IXT)

Східноукраїнського національного університету імені Володимира Даля

Попов Євген Вадимович

д-р.техн.наук, проф. кафедри екології і полімерів

Iнститут хімічних технологій (IXT)

Східноукраїнського національного університету імені Володимира Даля

Мороз Олексій Валерійович

канд. техн. наук, викладач кафедри екології і полімерів

Інститут хімічних технологій (IXT)

Східноукраїнського національного університету імені Володимира Даля

УКРӒ̈НА

В продовження робіт, що опубліковані в повідомленнях [1, 2], в даному повідомленні наводяться результати дослідження 3 використаням синтезованих термопереводних дисперсних антрахінонових барвників 3 компонентів коксового газу і смоли, виделених після коксування кам'яного вугілля, за методом сухого термодрукування.

Сухе термодрукування з паперу на тканину з синтетичних волокон широко використовується у світовій текстильної промисловості. Воне придатне для колорування поліефірних, поліамідних, поліетилентерефталатних, тріацетатних і діацетатних тканин, а також змішаних тканин, що містять 20- 
30\% натуральних волокон. Для нанесення барвнику на паперову основу використовуються сітчасті шаблони. Можна також використовувати інші різні методи друкування: офсетний, флексографський, глибокий та ін., що надають хорошу якість рисунку. Термодрукування 3 паперу на тканину крім синтетичних тканин можливо здійснювати також на покритих поліефірним лаком металевих або деревних поверхнях. Сутність методу полягає в наступному: на папір поліграфічним способом наноситься рисунок друкарськими фрарбами, що містять у складі легко сублімуючі моноазо- або антрахінонові барвники [1, 2], які з надрукованого зображення на паперовій підложки при тепловому впливі рисунок переноситься з неї на полієфірну тканину. Для здійснення процесу переводу рисунка термодрукуванням повинні бути забезпечені такі необхідні вимоги:

- якісний папір і технологія поліграфічного друкування по ньому;

- синтетична тканина для термопереводного рисунка повинна витримувати температуру до $230^{\circ} \mathrm{C}$ протягом 60 хв.;

- підбір гами яскравих дисперсних барвників, у тому числі і змішаних, яки здатні до максимального ступеня сублімації на синтетичну тканину при однакових умовах;

- вибір раціональних технологічних прийомів термопереводу рисунка 3 паперового зразку на обрану синтетичну тканину.

Кількість барвнику, що переходить при сухому термодрукуванні з паперу на тканину, визначали в процесі дослідження методом прямого фотоспектрування зразків поліефрірної тканини з надрукованиго зображення 3 подальшими розрахунками фрарбувальної здатності за даними фрункцій $K / S$ Гуревича-Кубелки-Мунка [6]. Сенс використання даної $K / S$-функції полягає в тому, що вона має лінійну залежність між концентрацією барвника на волокні та відсотком відбитку \на спектрофотометричній кривій, тобто

de:

$$
K / S=a \cdot C,
$$

a- коефріцієнт,

C - концентрація барвника на поверхні волокна.

Для визначення ступеня переходу барвника з надрукованого паперу на субстрат (поліефірну тканину) були взяті синтезовані термопереводні барвники з передчасно тонкодиспергованою і модифрікованою поверхнею часточок. Вибір дисперсних барвників для переводного термодрукування здійснювали за такими нетрадиційними властивостями, як здатність до максимального ступеня сублімації і термостабільність при $180-220^{\circ} \mathrm{C}$; забезпечення максимальної інтенсивності та яскравості зображення за нетривалий проміжок часу термопереводу $(45-60$ c). 3 цією метою були визначені швидкості термопереходу синтезованих дисперсних барвників при мінімальній температурі термопереводу синтезованих дисперсних барвників при мінімальній температурі термопереводу з отриманням максимальної якості з надрукованого заздалегідь паперу для шпалер на поліефірну тканину і стійкість до різних видів дій при використанні переведеного зображення [4-5]. 
Таблиця 1

Фізико-хімічні характеристики деяких дисперсних барвників, що вибрані для термопереводного друкування на поліефірних тканинах

\begin{tabular}{|c|c|c|c|c|c|c|c|c|}
\hline \multirow[t]{2}{*}{$\begin{array}{l}\text { № } \\
\text { п/п }\end{array}$} & \multirow[t]{2}{*}{$\begin{array}{l}\text { Структурна формула } \\
\text { дисперсного барвнику* }\end{array}$} & \multirow[t]{2}{*}{$\begin{array}{l}\mathrm{T}_{\text {пл.: }} \\
{ }^{\circ} \mathrm{C}\end{array}$} & \multirow[t]{2}{*}{$\begin{array}{l}\text { Мол. } \\
\text { маса }\end{array}$} & \multirow[t]{2}{*}{${ }^{*}\left(A^{3}\right) \cdot 10^{-3}$} & \multirow[t]{2}{*}{$\begin{array}{l}\varepsilon, * * \\
\text { дебай }\end{array}$} & \multicolumn{2}{|c|}{$\begin{array}{c}\text { Ступінь } \\
\text { сублімації } \\
\text { при }\end{array}$} & \multirow[t]{2}{*}{$\begin{array}{c}Q_{\text {субл,. }} \\
\text { (ккал/моль) }\end{array}$} \\
\hline & & & & & & $180^{\circ} \mathrm{C}$ & $200^{\circ} \mathrm{C}$ & \\
\hline 1 & $N-\mathrm{N}_{\mathrm{C}_{2} \mathrm{H}_{4} \mathrm{OH}}^{\mathrm{C}_{2} \mathrm{H}_{5}}$ & $159-160$ & 314 & 2,0 & 8,10 & 5,6 & 15,9 & 28,4 \\
\hline 2 & $=-8-\mathrm{B}_{2}^{\mathrm{c}_{2} \mathrm{H}_{5}}$ & $188-189$ & 357 & 1,8 & - & 17,2 & 36,1 & 37,6 \\
\hline 3 & & - & 280 & 1,9 & 6,12 & 14,4 & 18,8 & 31.8 \\
\hline 4 & & $270-272$ & 283 & 1,5 & 4,87 & 2,8 & 7,1 & 40,0 \\
\hline 5 & & $267-268$ & 238 & 1,4 & 3,71 & 9.8 & 21,8 & 33,0 \\
\hline 6 & & - & 239 & 1,3 & 2,40 & 20,0 & 41,6 & 29,8 \\
\hline 7 & & 195 & 240 & - & - & 34,5 & - & 22.2 \\
\hline 8 & & $239-240$ & 269 & 1,5 & 4,66 & 6,3 & 14,8 & 35,0 \\
\hline 9 & & - & 296 & 1,7 & 1,12 & 9,3 & 23,4 & 37,2 \\
\hline 10 & 10 & - & 298 & - & - & 7.1 & 16,7 & - \\
\hline
\end{tabular}

*Об'єм молекули барвника; **Дипольний момент в діоксані.

Авторська розробка.

Вплив різних високомолекулярних зв'язуючих, які одночасно $\epsilon$ згущувачами композицій в друкарській фарбі (в залежности від методу її нанесення), і температури на їх термопереход з надрукованого на паперу для 
шпалер зображення на поверхню поліефрірної тканини було вивчено на прикладі поліграфічної фрарби 3 моноазо- і антрахіноновими термопереводними барвниками: жовтим 3, рожевим 2C та синім 3. Для нанесення барвника на папір готували друкувальну фарбу наступного складу (г/кг): барвник - 20; ОПЦ - оксипропилцелюлоза (3\%-на) - 600-700; резінат натрію або кальцію- 20; вода - до 1000 (табл. 2). Результати отриманих даних приведені нижче в табл. 2, з якої видно, що кращі результати мають зразки, де в якості зв'язуючого використана оксипропилцелюлоза (ОПЦ).

Друкувальну фарбу у виробничих умовах наносили на високо якісний папір для шпалер з допомогою багатовальної шпалеродрукувальної машини. Термоперевод зображення здійснювали на видбеленій синтетичній тканині в лабораторії за допомогою лабораторного термопресу при таких температурних і часових режимах для тканин: поліефрірна, арт. 2140 - 190$210^{\circ} \mathrm{C}, 20-25$ c; триацетатна і поліамідна, арт. $52203-190-200^{\circ} \mathrm{C}, 35-40 \mathrm{c} \mathrm{i}$ ацетатна - $185-195^{\circ} \mathrm{C}, 25-30$ с. Отримані дані впливу різних зв'язуючих в друкарській фарбі і термопереход на поліефірну тканину приведені в табл. 3.

Таблиця 2

Склади друкарських фрарб для друкування сітчастими шаблонами по паперу для шпалер з використанням різної зв'язуючої основи

\begin{tabular}{|c|c|c|c|c|c|c|c|c|c|}
\hline $\begin{array}{c}\text { Найменувания } \\
\text { компонентів в фарбі }\end{array}$ & \multicolumn{9}{|c|}{ Кількість компонентів в друкарській фрарбі, г/кг } \\
\hline Термопереводний барвник & 20 & 20 & 20 & 20 & 20 & 20 & 20 & 20 & 20 \\
\hline $\begin{array}{l}\text { Зв'язуюча основа* } \\
\text { - крохмаль } \\
\text { - манутекс RS } \\
\text { - сольвітоза С-5 } \\
\text { - КМЦ } \\
\text { - ОЭЦ } \\
\text { - ОПЦ } \\
\text { - МЦு }\end{array}$ & 100 & 25 & 60 & 60 & 60 & 80 & 25 & 25 & 80 \\
\hline $\begin{array}{l}\text { ПАР: } \\
\text { - резинат натрію або } \\
\text { - резинат кальцію, або } \\
\text { - стеарокс-6 }\end{array}$ & 10 & 10 & -10 & -10 & 10 & 10 & 10 & 10 & 10 \\
\hline Уайт-спирит & - & - & - & - & - & - & - & 100 & 100 \\
\hline Вода & \multicolumn{9}{|c|}{ Усюди до 1000} \\
\hline
\end{tabular}

*Манутекс RS, Англія (аналог високов'язкого зв'яязуючого); сольвитоза марки С-5 (карбоксиметилкрохмаль);

КМЦ - карбоксиметилцелюлоза; ОЭЦ - оксиетилцелюлоза; ОПЦ - оксипропилцелюлоза; МЦ метилцелюлоза.

Стеарокс-6 (суміш поліетиленгліколевих ефірів стеаринової кислоти).

Авторська розробка.

Процес термопереводной друкування по синтетичних тканинах істотно спрощує технологію в порівнянні з базовим процесом друкування [1]. 
Таблиця 3

Вплив різних зв'язуючих в друкарській фарбі і температури на термопереход (K/S) барвнику 3 паперу на поліефірну тканину

\begin{tabular}{|c|c|c|c|c|c|}
\hline \multirow{3}{*}{$\begin{array}{c}\text { Температура } \\
\text { сублімації } \\
\text { барвнику, }{ }^{\circ} \mathrm{C}\end{array}$} & \multicolumn{5}{|c|}{$\begin{array}{c}\text { Термопереход барвнику з паперу на поліэфірну тканину в залежності від } \\
\text { зв'язуючого у вигляді K/S-функції Гуревича-Кубелки-Мунка }\end{array}$} \\
\hline & \multicolumn{5}{|c|}{ Зв'язуюча основа для друкарської фарби } \\
\hline & МЦ & ОПц & ОЭЦ & Сольвитоза & Манутекс RS \\
\hline \multicolumn{6}{|c|}{ Дисперсный жовтий 3} \\
\hline $\begin{array}{l}150 \\
160 \\
170 \\
180 \\
190 \\
200 \\
210 \\
220 \\
\end{array}$ & $\begin{array}{l}0,787 \\
1,700 \\
4,050 \\
5,794 \\
6,845 \\
7,013 \\
7,153 \\
7,227 \\
\end{array}$ & $\begin{array}{l}1,993 \\
4,481 \\
5,980 \\
6,387 \\
6,844 \\
7,182 \\
7,227 \\
7,227\end{array}$ & $\begin{array}{l}0,660 \\
2,205 \\
4,366 \\
5,617 \\
6,387 \\
6,725 \\
7,096 \\
7,227\end{array}$ & $\begin{array}{l}1,824 \\
4,481 \\
5,980 \\
6,725 \\
6,844 \\
6,844 \\
6,844 \\
6,844 \\
\end{array}$ & $\begin{array}{l}1,354 \\
2,667 \\
3,096 \\
4,481 \\
4,601 \\
4,726 \\
4,925 \\
5,290\end{array}$ \\
\hline \multicolumn{6}{|c|}{ Дисперсний рожевий 2C } \\
\hline $\begin{array}{l}150 \\
160 \\
170 \\
180 \\
190 \\
200 \\
210 \\
220\end{array}$ & $\begin{array}{l}0,288 \\
0,680 \\
1,237 \\
2,060 \\
2,452 \\
3,384 \\
3,770 \\
3,953\end{array}$ & $\begin{array}{l}0,591 \\
0,886 \\
1,993 \\
3,031 \\
3,481 \\
3,953 \\
4,021 \\
4,150\end{array}$ & $\begin{array}{l}0,272 \\
0,410 \\
0,926 \\
1,809 \\
3,062 \\
3,953 \\
4,018 \\
4,111\end{array}$ & $\begin{array}{l}0,753 \\
0,758 \\
2,498 \\
2,970 \\
3,520 \\
3,600 \\
3,616 \\
3,684\end{array}$ & $\begin{array}{l}0,842 \\
1,508 \\
1,898 \\
2,244 \\
2,303 \\
2,344 \\
2,408 \\
2,452\end{array}$ \\
\hline \multicolumn{6}{|c|}{ Дисперсний синій 3} \\
\hline $\begin{array}{l}150 \\
160 \\
170 \\
180 \\
190 \\
200 \\
210 \\
220 \\
\end{array}$ & $\begin{array}{l}0,120 \\
0,178 \\
0,208 \\
0,394 \\
0,817 \\
2,641 \\
4,256 \\
5,066\end{array}$ & $\begin{array}{l}0,461 \\
0,672 \\
0,763 \\
1,245 \\
1,838 \\
2,771 \\
3,860 \\
4,662\end{array}$ & $\begin{array}{l}0,122 \\
0,308 \\
0,455 \\
0,521 \\
0,607 \\
2,113 \\
3,726 \\
4,540\end{array}$ & $\begin{array}{l}0,376 \\
0,754 \\
0,926 \\
1,373 \\
2,078 \\
2,641 \\
3,726 \\
4,366\end{array}$ & $\begin{array}{l}0,255 \\
0,422 \\
0,503 \\
0,506 \\
0,589 \\
1,132 \\
2,186 \\
2,498\end{array}$ \\
\hline
\end{tabular}

*/нтенсивність термопереводу відображена у вигляді функції К/S Гуревича-Кубелки-Мунка. Авторська розробка.

По значенням відбиття по спектрам визначали величину функції ГуревичаКубелки-Мунка (K/S) 3 кожних температурних і часових параметрів термопереводу барвнику на різних зразках поліефрірних тканин. Інтенсивність (величину функції $K / S_{\infty}$ ) зі стандартним надрукованим зразком барвника умовно приймали за $100 \%$. Якщо зміну фарбувальної здатності в залежності від концентрації $C$ термопереводного дисперсного барвника в рівнянні $K / S$ функції Гуревича-Кубелки-Мунка [3] перетворювати в рівність лінійного виду, то отримується рівнення такого виду:

de:

$$
\frac{C}{K / S}=\frac{C}{K / S_{\infty}}+\frac{1}{\frac{n p .}{\text { воз2. }}}
$$

$K_{\frac{n p .}{\text { возг. }}}$ - приведена константа возгонки барвника зі спектрів відбиття;

C - концентрація термопереводного барвнику (г/кг);

$K / S_{\infty}$ - максимально досяжне значення K/S-фрункції Гуревича-Кубелки-Мунка, яке відповідає нескінченно великої концентрації барвника у складі фарбувальної термопереводної композиції. 
72 Problems and prospects of implementation of innovative research results $\bullet$ Volume 2

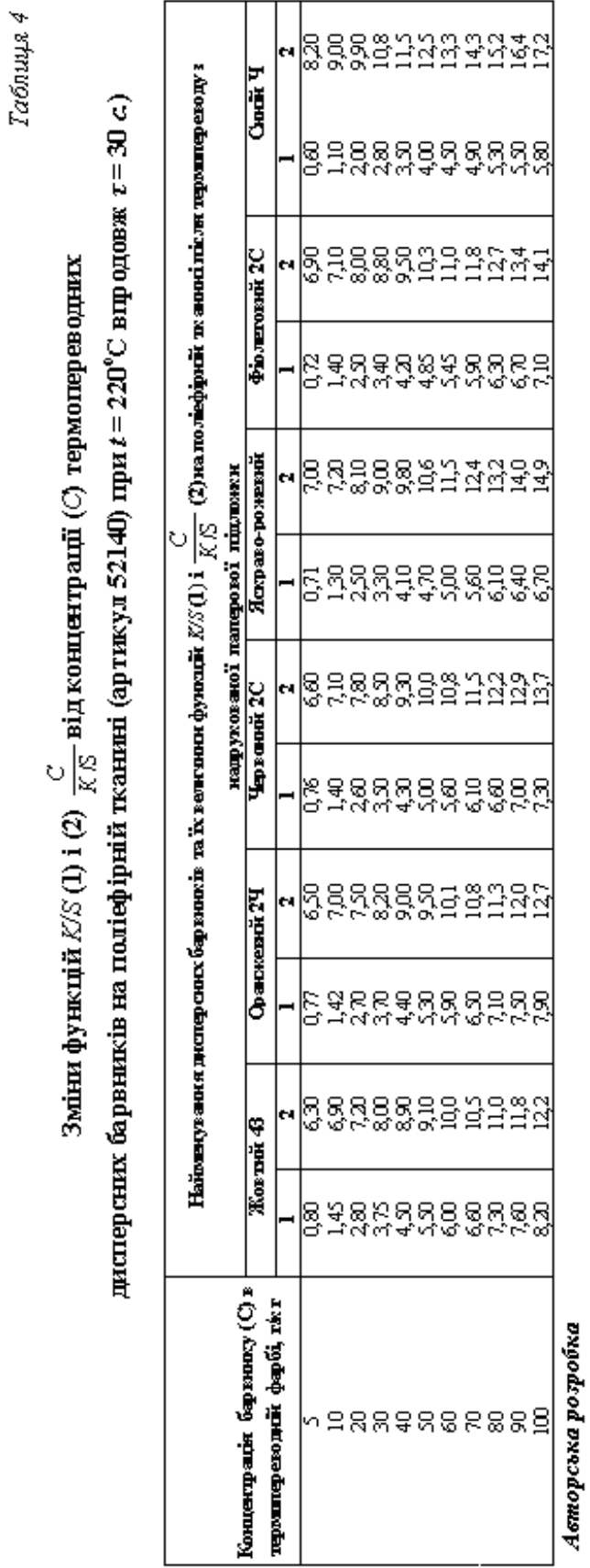


Із раніше синтезованих термопереводних барвників [1, 2] був розроблений склад поліграфічної фарби для шпалер з термопереводними барвниками і освоєна в дослідницькому цеху інституту хімічних технологій і промислової екології (IXTПЕ, м. Рубіжне, Україна) технологія виробництва дитячих 6- і 12кольорових термопереводних олівців і акварельних фарб (ТУ У 6-04872671) для (див. рис.) малювання на папері (а) з подальшим термопереводом рисунку з папіру на тканину із синтетичних волокон (б), які мають досить високи показники стійкості до світла і світло-погоди, мила, «поту», сухого тертя.

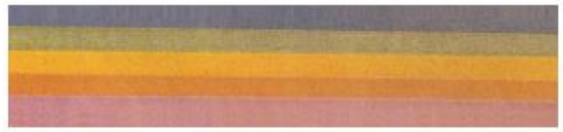

2

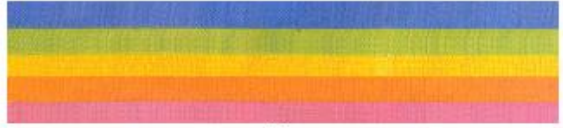

6

ВИСНОВКИ. Досліджені колористичні властивості термопереводних барвників в умовах термопереводного друкування з паперу для шпалер на поліефірні тканини, визначені оптимальні концентрації барвників широкої кольорової гами та їх вплив наінтенсивність в друкарській фрарбі і стійкість термопереводних зображень на тканині до фрізико-хімічних дій.

\section{Список використаних джерел:}

1. Вигоняйло, О., Попов, Є., \& Мороз, О. (2019). Синтез термопереводних моноазобарвників. А'ОГОГ. ОНЛАЙН. ЕОІ: 10.11232/2663-4139.02.05.

2. Вигоняйло, О., Попов, Є., \& Мороз, О. (2019). Синтез термопереводних антрахінонових барвників. АОГОГ. ОНЛАЙН. ЕОІ: 10.11232/2663-4139.03.01.

3. Hauser P. \& Honigman B. (1975). Optimierung coloristischer Eigenschaften organischer Pigment emit Hilfe der Kubelka-Munk- und der Mie-Theorie. Farbe und Lack. Bd. 81, (11), 1005-1011.

4. Вигоняйло, В.І., Попов, Є.В. \& Мороз, О.В. (2019). Промислове отримання барвників для триади переводного термодрукування на тканинах з поліефірних синтетичних волокон. Problèmes et perspectives d'introduction de la recherche scientifique innovante: collection de papiers scientifiques " $\mathrm{\Lambda} \mathrm{O} \Gamma \mathrm{O}$ " avec des matériaux de la conférence scientifique et pratique internationale (Vol. 3, pp. 25-35), 29 novembre, 2019. Bruxelles, Belgique: Plateforme scientifique européenne. Retrieved from https://ojs.ukrlogos.in.ua/files/journals/4/issues/74/public/74-264PB.pdf\#page $=25$.

5. Вигоняйло, В.І., Попов, Є.В. \& Мороз, О.В. (2019). Модифікування поверхні барвників для термопереводного друкування. Science and Practice: Implementation to Modern Society: Proceedings of the 1st International Scientific and Practical Conference (December 6-8, 2019), Manchester. Great Britain: Peal Press Ltd., 2019. pp. 21-27. Retrieved from https://www.interconf.top/documents/2019.12.6-8.pdf\#page=15. 


\section{ДОСЛІДЖЕННЯ ЗАСОБІВ ВІЗУАЛЬНОГО ПРОГРАМУВАННЯ ДЛЯ РОЗРОБКИ АНІМАЦІЙ НАУКОВОГО СПРЯМУВАННЯ}

НАУковО-ДОслІДНА ГРУПА:
Кічатов Олександр Сергійович
магістр
Національна металургійна академія України
Селівьорстова Тетяна Віталіївна
канд. техн. наук, доцент
Національна металургійна академія України
Селівьорстов Вадим Юрійович
д-р. техн. наук, профресор
Національна металургійна академія України
УКРАїнА

Поширення інформації про результати наукових досліджень, 3 метою їхнього впровадження, передбачає можливість їхньої наглядної демонстрації. На теперішній, одним із стандартів в просуванні інформації, $є$ анімаційні відео. Саме тому питання ефективної розробки анімацій наукового спрямування $\epsilon$ актуальним для науковців України.

На сьогоднішній день в світі $є$ дуже великий обсяг наукової інформації. В процесі пізнання будь-якої з наук доведеться копатися в купах книг, доповідей, статей, адже процес наукової діяльності являє собою вивчення певної теми, розробці поліпшеної методології і її узагальнення у вигляді доповіді, статті й т.д. Метою роботи є визначення ефективних технологій для розробки анімації та їхнього застосування в умовах навчального процесу. Застосування відео у навчальному процесі дозволяє значно збільшити наочність та ефективність засвоєння матеріалу.

В ході аналізу наявних на ринку програмного забезпечення, було обрано Adobe Flash [1] тa Adobe After Effects [2].

Adobe Flash - мультимедійна платформа компанії Adobe Systems для створення веб-додатків або мультимедійних презентацій. Широко використовується для створення рекламних банерів, анімації, ігор, а також відтворення на веб-сторінках відео- і аудіозаписів.

Adobe Flash дозволяє працювати з векторною, растровою і з тривимірною графікою, використовуючи при цьому графічний процесор, а також підтримує двонаправлену потокову трансляцію аудіо і відео. Для КПК і інших мобільних пристроїв випущена спеціальна «полегшена» версія платформи Flash Lite, функкціональність якої обмежена в розрахунку на можливості мобільних пристроїв і їх операційних систем.

Adobe After Effects - програмне забезпечення компанії Adobe Systems для редагування відео і динамічних зображень, розробки композицій (композітінг), анімації і створення цифрових відеоефектів. Назва походить від ефекту, відомого як «стійкість (інертність) зорового відчуття», цей механізм 
використовує сенсорну пам'ять сітківки ока, яка дозволяє зберігати зорову інфрормацію протягом короткого проміжку часу.

Завдяки великій бібліотеці плагінів, розроблених сторонніми компаніями, AfterEffects також використовується в поліграфії та графічному дизайні для редагування статичних графічних зображень (фотографій, зображень, згенерованих на комп'ютері і т.д.).

Предметом розробки є розробка анімації технології газодинамічного тиску на метал, що твердіє в ливарній формі [3]. Дана технологія була розроблена професором кафедри ливарного виробництва НМетАУ Селівьорстовим В.Ю. Розроблено візуалізацію процесу заливання розплаву в ливарну форму, герметизації системи виливок-пристій для введення газу, процесу затвердінні виливку під дією газо-динамічного тиску, особливості утворення усадкових дефектів.

\title{
Список використаних джерел:
}

1. Adobe Flash Player. 2019. Вилучено з https://www.adobe.com/ua/products/flashplayer.html.

2. Kуnyŭme Adobe After Effects | Програмне забезпечення для створення візуальних ефректів і анімованої графріки. 2019. Вилучено з https://www.adobe.com/ua/products/aftereffects.html.

3. Селівьорстов В. Ю. (2011). Теоретичні і технологічні основи газодинамічного впливу на метал, що твердіє в ливарній формі (дис. докт. техн. наук). Ливарне виробництво. Дніпро.

\section{ДОСЛІДЖЕННЯ ТА ПОРІВНЯЛЬНИЙ АНАЛІЗ МЕТОДІВ ВИРІШЕННЯ ЗАДАЧІ КОМІВОЯЖЕРА}

\author{
Решетник Вікторія Романівна \\ Здобувач вищої освіти технічного факультету \\ Вінницький національний технічний університет
}

НАУКОВИЙ КЕРІВНИК:

Петришин Сергій Іванович

ст. викл. кафредри комп'ютерних наук Вінницький національний технічний університет

УКРАÏHA

Особливістю нинішнього етапу розвитку науки в економічній діяльності є підвищення інтересу фахівців до наукового вирішення проблем 3 використанням економіко-математичних методів, моделей засобами інформаційних технологій.

Задачі комбінаторної оптимізації зустрічаються на практиці постійно. Однак довгий час вони не привертали до себе пильної уваги дослідників, так як в більшості випадків для їх вирішення знаходився якийсь природний алгоритм на подобі прямого перебору [1]. Пошук більш раціональних алгоритмів в той час не міг представляти інтересу для задач малої і великої розмірності, оскільки в першому випадку такі алгоритми ненабагато краще природного, а в другому - 
вони так само, як і природний алгоритм, не призводять до вирішення через великий обсяг обчислень [2].

Задача комівояжера - traveling salesman problem $€$ NP-складною задачею дискретної оптимізації. Головною проблемою даної задачі $є$ те, що для неї не знайдено і можливо не існує швидких поліноміальних алгоритмів [3].

Результати дослідження. Під час обговорення методу "грубої сили" (послідовний перебір) була сформульована задача комівояжера: $€ \mathrm{~N}$ міст, з'єднаних між собою дорогами. Необхідно прокласти між ними найкоротший замкнутий маршрут, що проходить через кожне місто тільки один раз.

Відстань з міста ј в місто і вважається невід'ємним числом: Dji $\geq 0$. Це не обов'язково "фізична довжина" дороги. "Відстанню" може бути час переміщення, вартість квитка або довільне невід'ємне число. Часто Dji називають вартістю ребра (edge costs), так як дороги можна уявити ребрами (edges), що з'єднують міста-вершини (vertices) деякого графа.

Для вирішення вказаної задачі можна використовувати алгоритм Дейкстри. Він знаходить найкоротшу відстань від однієї вершини графа до всіх інших. Недоліком алгоритму $є$ те, що він не завжди працює з ребрами при від'ємному значенні ребер [4].

Алгоритм динамічного програмування Флойда-Уоршелла служить для визначення найкоротших шляхів між усіма парами вершин графа.

Даний алгоритм дуже простий у освоєнні, але у нього дуже низька швидкість роботи і в ньому не передбачено розрахунок ребер з негативними вагами.

Метод Флойда базується на тому факті, що в графі з позитивними вагами будь-якого неелементарного ребра (що містить більше 1 ребра), короткий шлях складається з інших найкоротших шляхів.

Дано матрицю, яка заповнюється вагами ребер для кожної з вершин. Після цього проводиться ітерація кожної вершини, де порівнюється вага ребер між вершинами А і Б, через вершину В. Найкоротшим шляхом між А і Б $є$ мінімальне значенн з цих варіантів [5].

Цей алгоритм більш загальний порівняно з алгоритмом Дейкстри, так як він знаходить найкоротші шляхи між будь-якими двома вершинами графа. Перегавою алгоритму $є$ його простота реалізації, слабкість - в складності алгоритму. Вона дорівнює, де - кількість вершин графа [6].

Алгоритм пошуку $A^{*}$ належить до евристичних алгоритмів пошуку. Він використовується для пошуку найкоротшого шляху між двома вершинами графу з додатніми вагами ребер. Алгоритм використовує допоміжну функцію (евристику), аби скеровувати напрям пошуку та скорочувати його тривалість. Основним недоліком алгоритму $A^{*} \epsilon$ потреба в пам'яті для збереження всіх відомих та досліджених вершин. Через це алгортим $A^{*}$ непридатний для багатьох задач.

Однією 3 основних проблем алгоритму $A^{*} \epsilon$ те, що одержані за його допомогою шляхи не виглядають реалістичними. В основі мурашиних алгоритмів лежать принципи самоорганізації мурашиної колонії в природі.

Мурахи відносяться до соціальних комах, що створюють колективи. Колективна система здатна вирішувати складні динамічні завдання з виконання спільної роботи, яка не могла б виконуватися кожним елементом системи окремо в різноманітних середовищах без зовнішнього управління, контролю або координації [7].

Незважаючи на роз'єднану поведінку кожного зі своїх представників, особини колонії утворюють високоорганізовану систему, що складається з 
великої кількості «агентів» - мурах, і завдяки цьому здатні вирішувати складні завдання, які перевищують можливості кожного окремого свого елемента.

Головну роль у втіленні соціальної поведінки мурах в природі становить самоорганізація. Одним із способів передачі інформації між мурахами $\epsilon$ стигмергія - поширений в часі тип взаємодії, при якому один суб'єкт деяким чином змінює частину навколишнього середовища, а решта суб'єктів використовують цю інформацію пізніше, коли знаходяться поблизу.

Результати перших експериментів із застосуванням мурашиного алгоритму для вирішення завдання комівояжера були багатообіцяючими, проте далеко не кращими в порівнянні з вже існуючими методами. Однак простота класичного мурашиного алгоритму залишала можливості для доробок - і саме алгоритмічні удосконалення стали предметом подальших досліджень Марко Доріго і інших фахівців в області комбінаторної оптимізації.

Одним з таких удосконалень $є$ введення в алгоритм так званих «елітних мурах». Показно, що проходячи ребра, що входять в короткі шляхи, мурахи 3 більшою ймовірністю будуть знаходити ще коротші шляхи. Таким чином, ефективною стратегією $€$ штучне збільшення рівня феромонів на найвдаліших маршрутах. Для цього на кожній ітерації алгоритму кожна з елітних мурах проходить шлях, який є найкоротшим зі знайдених на даний момент [8].

Бернд Бульнхаймер, Ріхард Хартл і Христина Штраусс розробили модифікацію класичного мурашиного алгоритму, в якому в кінці кожної ітерації мурахи ранжуються у відповідність 3 довжинами пройдених ними шляхів. Кількість феромонів, що залишається мурахою на ребрах, таким чином, призначається пропорційно його позиції. Крім того, для більш ретельного дослідження околиць вже знайдених вдалих рішень, алгоритм використовує елітних мурах.

Ефективність мурашиних алгоритмів порівнянна з ефективністю загальних метаевристичними методами, а в ряді випадків - і з проблемно-орієнтованими методами. Найкращі результати мурашині алгоритми показують для задач 3 великими розмірностями областей пошуку.

Мурашині алгоритми добре підходять для застосування разом 3 процедурами локального пошуку, дозволяючи швидко знаходити початкові точки для них [9].

Висновки. Було розглянуто алгоритми, які використовуються для вирішення задачі комівояжера, а саме: алгоритм Дейкстри, алгоритм ФлойдаУоршелла, алгоритм $A^{*}$ та мурашині алгоритми. Всі розглянуті в роботі алгоритми та методи оптимізації мають практичну значущість. На сьогоднішній день для задач великої розмірності використовуються інтелектуальні алгоритми, як наприклад, мурашиний алгоритм. Тому можна зробити висновок, що задача комівояжера $є$ цікавою з точки зору отримання нових, вдосконалених алгоритмів дискретної оптимізації на масивах великої розмірності, які застосовуються не тільки в економічних розрахунках, але й у побудові комп'ютерних мереж, трафіку в мережах, розподілу ресурсів і т. д.

\section{Список використаних джерел:}

1. Крупский, В.Н.& Плиско В.Е.(2013). Математическая логика и теория алгоритмов: учебное пособие для студентов учреждений высшего проф. образования. Москва: ИЦ Академия.

2. Левитин А. \& Красиков И. (2006). Алгоритмы: введение в разработку и анализ. Москва: Вильямс. 
78 Problems and prospects of implementation of innovative research results $\bullet$ Volume 2

3. Кормен Т., Лейзерсон Ч., Ривест Р. \& К. Штайн. (2005). Алгоритмы: построение и анализ. Москва: Вильямс.

4. Семакин, И. Г. \& Шестаков А. П. (2013). Основы алгоритмизации и программирования: учебник для студентов учреждений среднего образования. Москва: ИЦ Академия.

5. Канцедал, С.А.(2013). Алгоритмизация и программирование: учебное пособие. Москва: ИД ФОРУМ.

6. Седжвик Р. (2012). Алгоритмы на Java: учеб. Пособие. Москва: Вильямс.

7. Семакин И. Г. \& Шестаков А. П. (2013). Основы алгоритмизации и программирования. Москва: ИЦ Академия.

8. Игошин В. И. (2013). Теория алгоритмов: учебное пособие. Москва: ИНФРА-М.

9. Colorni A., Dorigo M. \& Maniezzo V. (1991). Distributed Optimization by Ant Colonies. Proceedings of the First European Conference on Artificial Life. June 16, 1991, Paris, France.

DOI 10.36074/13.12.2019.v2.08

\section{ЕКСПРЕС ОЦІНЮВАННЯ ЙМОВІРНОГО ПРОГИНУ ЕЛЕКТРОНАСОСНОГО АГРЕГАТУ НА ХАРАКТЕРНИХ ДІЛЯНКАХ СВЕРДЛОВИНИ}

НАУКОВО-ДОСЛІДНА ГРУПА:

Джус Андрій Петрович

д-р. техн. наук, доцент, професор кафедри нафтогазових машин та обладнання Івано-Франківський національний технічний університет нафрти і газу

Михайлюк Василь Володимирович канд. техн. наук, доцент, доцент кафедри нафтогазових машин та обладнання Івано-Франківський національний технічний університет нафтти і газу

Дейнега Руслан Олександрович асистент кафедри нафтогазових машин та обладнання Івано-Франківський національний технічний університет нафоти і газу

Коник Андрій Михайлович здобувач вищої освіти інституту інженерної механіки Івано-Франківський національний технічний університет нафоти і газу

УКРАÏHA

Робота установок штангових свердловинних насосів (УШСН) та особливо насосних штанг у свердловинах складного профрілю характеризується їх інтенсивним зносом і аваріями. У зв'язку з цим, на сьогодні, доволі поширеним $€$ облаштування таких свердловин установками електровідцентрових насосів (УЕВН). Таким чином фонд свердловин обладнаних УЕВН поступово поповнюється в окремих випадках проблемними, найчастіше малодебітними свердловинами, переведеними з УШСН на УЕВН. 
Як правило, для різних видів ускладнень фахівцями нафтопромислової справи розроблені і застосовуються на практиці заходи щодо зниження шкідливого впливу ряду чинників. Наприклад, для зниження впливу механічних домішок на роботу ЕВН у складі установок широко використовують щілиноподібні фільтри. Доволі поширеним є варіант їх встановлення в нижній частині обсадної колони. Зменшення швидкості фільтрації у привибійній зоні сприяє зниженню винесення механічних домішок з продуктивного пласта. Для мінімізації шкідливого впливу на роботу ЕВН пропанту, що використовується при проведенні ГРП, розроблені технології з його якісного закріплення в тріщині шляхом плавної релаксації тиску гідророзриву до рівня поточного значення пластового тиску. Освоєння свердловини після ГРП здійснюють за технологією, що забезпечує обмежену в часі депресію на продуктивний пласт.

Для попередження зниження опору ізоляції системи кабель-двигун нафтогазовидобувні підприємства використовують теплостійкі кабелі i занурювальні електродвигуни (ЗЕД). Для зниження ризику “задирів" броні кабельної лінії і пошкодження ізоляції внутрішню поверхню експлуатаційної колони очищають від продуктів корозії, солей, цементної кірки спеціальними пристроями. В експлуатаційну колону попередньо спускають шаблон, довжина та діаметр якого перевищують відповідні габарити планованої для використання УЕВН. Окрім цього на викривлених інтервалах стовбура свердловини обмежують швидкість спуску УЕВН, використовують протекторицентратори, що монтуються безпосередньо на насосному обладнанні та муфттах насосно-компресорних труб.

Окремі із зазначених вище чинників, як самостійно, так і за спільної їх дії, можуть призводити до заклинювання ЕВН. Схильними до заклинювання переважно $€ \mathrm{EBH}$, що експлуатуються у свердловинах з невеликими для УЕВН дебітами, а саме від $10 \mathrm{~m}^{3}$ до $25 \mathrm{~m}^{3}$. Режим роботи таких свердловин переважно не стабільний, зважаючи на випереджаючий рух газу до вибою свердловини, що спостерігається при тиску на вибої більш ніж у 2 рази нижче тиску насичення $\mathrm{P}_{\text {нас. }}$ Створювані в зоні перфорації продуктивного пласта пробки газу піднімаються до ЕВН і при розбалансованості системи "пластсвердловина-насос" спричиняють зрив подачі. При цьому ЗЕД може тривалий час обертати вал ЕВН з робочими колесами, розігріваючи пластову рідину в його порожнині. Як наслідок на поверхні твердих тіл у вигляді кристалів відкладаються солі, що за певних умов призводить до заклинювання ЕВН. Спроби ж його розклинювання силовими методами або шляхом встановлення у свердловині "кислотної ванни" призводять до перегріву ЗЕД, зниження опору ізоляції і, в кінцевому підсумку, до повної відмови.

Для усунення, чи хоча б зменшення впливу ряду чинників доволі часто доводиться збільшувати глибину спуску ЕВН. В той же час реалізація таких заходів тягне за собою підвищення ймовірності пошкодження кабелю при спускопідіймальних операціях, збільшення температури в зоні розташування установки, збільшення необхідного напору насоса тощо. Тому актуальним $\epsilon$ питання можливості розташування та експлуатації обладнання в обраному для цього інтервалі. 
Розташування насоса нижче отворів перфорації призводить до відсутності омивання ЗЕД пластовою рідиною і ймовірності його перегріву. Для запобігання цьому підприємства виготовлювачі пропонують до використання кожухи для ЗЕД діаметром 103 та 117 мм. Вони кріпляться з допомогою спеціальних хомутів до насоса або газосепаратора вище зони вхідних отворів і забезпечують примусове обтікання ЗЕД пластовою рідиною. Цим забезпечується належне охолодження двигуна, однак невід'ємним $\epsilon$ збільшення габариту насосного агрегату і створення додаткових обмежень щодо можливості його спуску на задану глибину.

На сьогодні окремими виробниками темп набору кривизни стовбура свердловини в зоні спуску УЕВН регламентується допустимою кривизною (2。 на 10 метрів). Також можливість проходження установкою ділянок кривизни визначається шляхом шаблонування колони. У будь-якому випадку успішність спускопідіймальних операцій та подальшої експлуатації обладнання залежить від результатів інклінометрії, точності ії оцінки та врахування особливостей конструкції агрегатів, що підлягають спуску.

Загалом мінімально допустимий зазор між насосним агрегатом та обсадною колоною, який гарантує безаварійний спуск і підйом обладнання, був знайдений і обґрунтований з врахуванням результатів експериментів і виробничого досвіду. Для різних комбінацій параметрів насосів та двигунів він вказується заводами виготовлювачами у технічних вимогах. Безпосередньо експлуатація насосних агрегатів на викривлених ділянках регламентується допустимим прогином. Для належної оцінки стану обладнання за умов його розташування у певному інтервалі свердловини необхідним $€$ співставлення їх форми та розмірів.

На сьогодні виробники УЕВН пропонують споживачам окрім обладнання ще й програмні продукти, що покликані спростити процес його вибору. Вони містять модулі, що відтворюють за результатами інклінометрії траєкторію свердловини у просторовому вигляді та передбачають можливість відображення в ній колони насосно-компресорних труб. Однак для спрощення та підвищення точності механізму визначення можливості експлуатації насосного агрегату в свердловині із попередньо обґрунтованою глибиною спуску доцільним $€$ розроблення способу експрес оцінки його ймовірного прогину в окремо взятому інтервалі.

Для цього використано можливості програмних продуктів на базі методу кінцевих елементів щодо параметричного проектування твердотільних моделей. На першому етапі з врахуванням результатів інклінометрії, а саме у попередньо вибраній системі координат за координатами точок побудовано вісь свердловини для окремо взятого інтервалу (рис. 1, а). Відносно неї сформовано тіло, що імітує ділянку експлуатаційної колони (рис. 1, б). За конструктивними параметрами обладнання, що входить до складу насосного агрегату, створено його спрощену модель і розташовано в заданому інтервалі експлуатаційної колони шляхом визначення положення верхнього перерізу (рис. 1, б). Зафіксувавши нижній переріз моделі насосного агрегату отримано картину, що відображає взаємне розташування його осі та осі свердловини (рис. 1, в). 


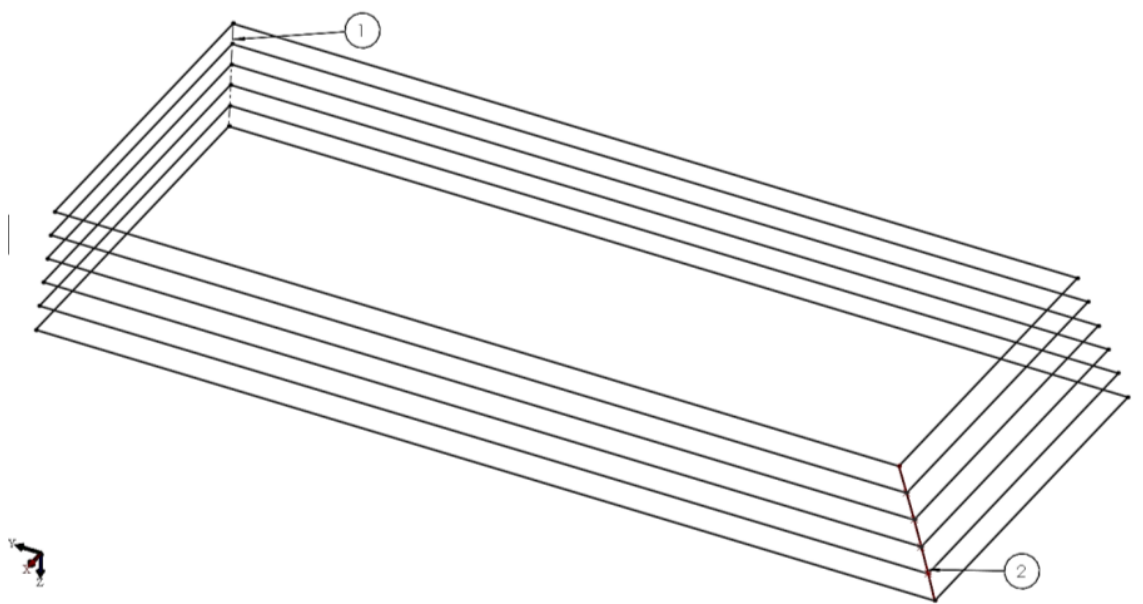

a)

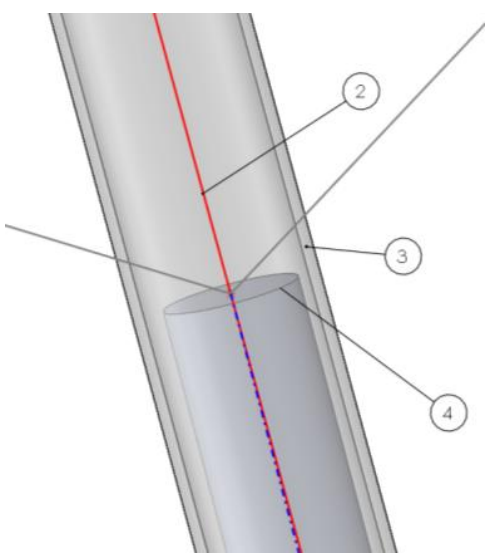

б)

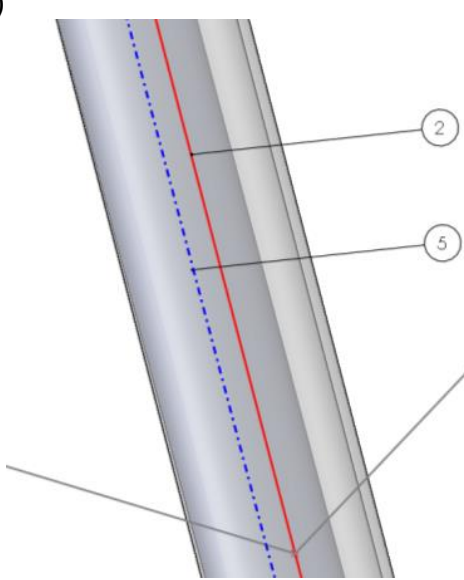

B)

1 - вісь системи координат; 2 - вісь свердловини; 3 - обсадна колона; 4 - насосний агрегат; 5 - вісь насосного агрегату; а) - побудова осі свердловини для окремо взятого інтервалу; б) - визначення положення насосного агрегату у свердловині; в) - взаємне розташування осей моделей

\section{Рис 1. Особливості формування моделі свердловини 3 розташованим в ній насосним агрегатом}

Отримана на цьому етапі інформація відображає тільки відхилення умовно прямолінійного агрегату від осі свердловини. Однак більш інформативною та необхідною для оцінки ймовірного прогину насосного агрегату $є$ інформація про контакт або й умовне перекриття тіл, що імітують агрегат та експлуатаційну колону. Встановивши переріз, що відповідає максимальному віддаленню їх осей (рис. 2, а), отримано значення перекриття зовнішньої поверхні насосного 
агрегату та внутрішньої стінки обсадної колони (рис. 2, б). Саме воно відповідає ймовірному прогину насосного агрегату за умов розташування у вибраному інтервалі і $\epsilon$ визначальним для прийняття рішення щодо можливості його експлуатації на попередньо обґрунтованій глибині спуску.

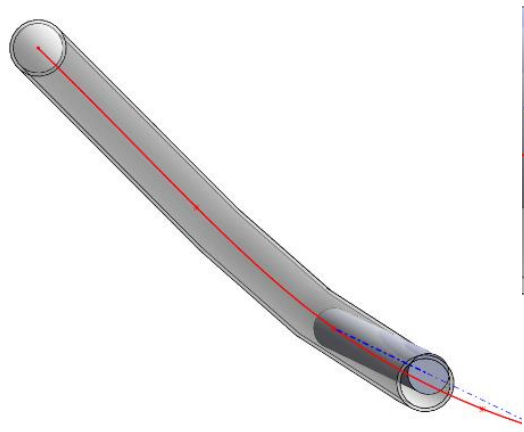

a)

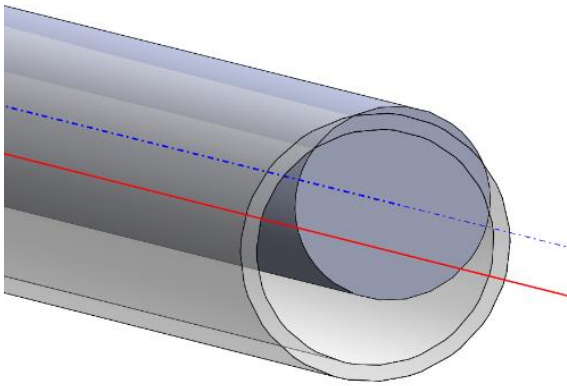

б)

а) - переріз максимального віддалення осей моделей; б) - перекриття зовнішньої поверхні насосного агрегату та внутрішньої стінки обсадної колони

\section{Рис 2. Особливості визначення ймовірного прогину насосного агрегату}

Висновок. Аналізуючи попередньо отримані результати слід зазначити, що при створенні моделі насосного агрегату необхідно врахувати особливості його комплектування, а для максимального відтворення конструктивних параметрів використати концентрично та не концентрично розташовані циліндричні елементи. Також необхідно відобразити особливості розташування верхніх та нижніх перерізів насосного агрегату у свердловині. 3 урахуванням зазначених моментів запропонований спосіб експрес оцінки ймовірного прогину насосного агрегату слугуватиме допоміжним механізмом для підтримки прийняття рішення щодо глибини спуску ЕВН. 


\section{ЖАДНЫЕ АЛГОРИТМЫ РАЗМЕЩЕНИЯ ПРЯМОУГОЛЬНИКОВ НА ПОЛУБЕСКОНЕЧНОЙ ЛЕНТЕ}

Гуляницький Л.Ф.

д-р. техн. наук, старший научный сотрудник Институт кибернетики имени В.М. Глушкова НАН Украины

Дубина А.B. магистрант фракультета информатики и вычислительной техники НТУУ «Киевский политехнический институт имени Игоря Сикорского»

УКРАИНА

\section{Введение.}

Задача размещения прямоугольников на полубесконечной ленте в разных ее модификациях находит применение в различных сферах деятельности, начиная с производственных и заканчивая сервисными отраслями. Работа посвящена исследованию одного типа задач размещения и алгоритмов их решения.

\section{1 Постановка задачи.}

Пусть имеем множество $A=\left\{a_{1}, \ldots, a_{N}\right\}$ из $N$ прямоугольников, которые необходимо разместить на полубесконечной ленте, состоящей из $K$ равных по ширине уровней, на каждом уровне имеем максимальное количество дырок $M$. На $k$ уровне задано расстояние $x_{k j}$ от начала ленты к $j$-й дырки, имеем, что $k=\overline{1, K}, j=\overline{1, M} ; b_{k j}$ - длина $j$-й дырки на $k$-м уровне, $z_{i}$ - расстояние от начала ленты до начала $i$-го прямоугольника, где $i=\overline{1, N}$ и $y_{i}$ - номер уровня, на котором размещен $i$-й прямоугольник, $i=\overline{1, N}$.

Математическую модель задачи можно представить так [1]:

$$
\begin{gathered}
x_{k_{j}} \geq 0, b_{k_{j}} \geq 0, k=\overline{1, K}, j=\overline{1, M}, \\
\alpha_{i}>0, z_{i} \geq 0, i=\overline{1, N}, \\
y_{i} \in\{1, \ldots, K\}, i=\overline{1, N},
\end{gathered}
$$

где для каждого і и всех $s \in\{1, \ldots, N\}$, таких, что $y_{i}=y_{s}, z_{i}<z_{s}$,

$$
z_{i}+\alpha_{i} \leq z_{s}
$$

для каждого $i, i=\overline{1, N}$ существует только одно $l \in\{0,1, \ldots, M\}$, такое, что

$$
\begin{aligned}
& x_{y_{i} l}+b_{y_{i} l} \leq z_{i} \leq x_{y_{i} l+1}-\alpha \\
& \max _{i=1, N}\left(z_{i}+\alpha_{i}\right) \longrightarrow \min
\end{aligned}
$$


Учитывая специфику представленных ограничений, использование традиционных методов математического программирования для решения задачи (1)-(6) нерационально или и вовсе невозможно ввиду больших временных затрат [1].

\section{2 Алгоритмы построения размещений}

Для приближенного решения задачи (1)-(6) рассмотрим эвристические методы, поскольку они позволяют находить решения довольно этих трудоемких задач, учитывая особенности ограничений [2].

Для решения поставленной задачи предлагается жадный алгоритм [3], который на каждом шаге, формируя очередной компонент вектора решения, делает локально наилучший выбор. Так как окончательное решение, полученное жадным алгоритмом, не всегда будет оптимальным, то в данной работе рассмотрим три вариации жадного алгоритма.

В каждом алгоритме на входе имеются количество прямоугольников $(N)$ и их размеры $\left(a_{i}\right)$, количество уровней $(K)$ и вся информация про дыры на каждом из уровне. Рассмотрим особенности каждого алгоритма далее.

Жадный алгоритм 1 (ЖА1)

Особенность алгоритма ЖА1 является то, что прямоугольники упорядочивают за убыванием их длины, т.е. первым будет размещаться самый длинный прямоугольник, а последним - самый короткий. На каждом этапе рассматриваются все возможные варианты размещения и очередной прямоугольник будет размещаться в той позиции, где общая длина занятой части ленты измениться минимально, или же никак. Ниже представим псевдокод ЖА1.

Алгоритм ЖА1.

1 Упорядочить прямоугольники $\left(a_{i}\right)$ по убыванию их длин;

2 while имеются неразмещенные прямоугольники

3 выбрать прямоугольник $a_{l}$;

$4 s_{i}$ :=определить длину уровня $i$, если там будет размещен прямоугольник;

5 j:=определить номер уровня, где $s_{j}$ минимальное или при размещении не изменилось;

6 на уровень ј поместить прямоугольник $a_{l}$;

7 определить уровень с максимальным значением длины последнего прямоугольника.

В этом алгоритме, прямоугольники размещаются таким образом, чтобы все последующие прямоугольники не значительно влияли на максимальную длину уровней, или вовсе не влияли.

Жадный алгоритм 2 (ЖА2)

Алгоритм ЖА2 является модификацией предыдущего алгоритма. Его особенностью является то, что прямоугольники упорядочены по возрастанию их размеров и первым будет размещаться прямоугольник с наименьшей длиной, а последний - с наибольшей.

Чтобы получить псевдокод данного алгоритма, необходимо в псевдокоде алгоритма ЖА1 заменить строку 1 на следующую:

1 Упорядочить прямоугольники $\left(a_{i}\right)$ по возрастанию их длин;

В отличии от предыдущего, в данном алгоритме необходимо сначала компактно разместить прямоугольники с наименьшей длиной. 
Жадный алгоритм 3 (ЖАЗ)

Алгоритмы, в которых прямоугольники берутся в определенном порядке, редко находят решение с удовлетворительной точностью. Многие приближенные алгоритмы получают лучшие результаты за счет использования случайных процессов. Поэтому в предлагаемом жадном алгоритме 3 прямоугольники упорядочиваются случайным образом. Для отображения этого в псевдокоде алгоритма ЖА1 необходимо также заменить только 1 строку:

1 Упорядочить прямоугольники $\left(a_{i}\right)$ случайным образом;

К преимуществу этого алгоритма можно отнести то, что его можно использовать в случае поступления прямоугольников в систему не одновременно, а в определенные моменты, в то время, как в остальных алгоритмах необходимо изначально знать размеры прямоугольников.

3 Результаты экспериментов.

Рассмотрим задачу размещения прямоугольников на полубесконечной ленте, которая состоит из $K=4$ уровней, на каждом уровне имеются $M=3$ дыры различной длины. Зададим:

$$
b=\left(\begin{array}{lll}
1 & 2 & 1 \\
2 & 1 & 2 \\
1 & 1 & 1
\end{array}\right), x=\left(\begin{array}{ccc}
1 & 7 & 14 \\
3 & 10 & 16 \\
0 & 7 & 13 \\
6 & 14 & 18
\end{array}\right),
$$

где $b_{k j}$ - длина j-й дырки на $k$-м уровне и $x_{k j}$ - расстояние от начала ленты до $j$-й дырки на к-м уровне, где $k=\overline{1, K}, j=\overline{1, M}$.

Для представленной задачи сгенерируем наборы определенного количества прямоугольников различной длины случайным образом. Сгенерированные прямоугольники размещались на полубесконечной ленте описанными тремя алгоритмами и исследуем, который из них даст лучшее размещение. Результаты проведенных экспериментов представим в таблице.

Результаты экспериментов

\begin{tabular}{|c|c|c|c|c|c|c|}
\hline $\begin{array}{c}\text { Количество } \\
\text { прямоуголь- } \\
\text { ников }\end{array}$ & $\begin{array}{c}\text { ЖА1 } \\
\text { (\%) }\end{array}$ & $\begin{array}{c}\text { ЖА2 } \\
\text { (\%) }\end{array}$ & $\begin{array}{c}\text { ЖА3 } \\
\text { (\%) }\end{array}$ & $\begin{array}{c}\text { Время } \\
\text { работы } \\
\text { ЖА1 (мс) }\end{array}$ & $\begin{array}{c}\text { Время } \\
\text { работы } \\
\text { ЖА2 (мс) }\end{array}$ & $\begin{array}{c}\text { Время } \\
\text { работы } \\
\text { ЖА3 (мс) }\end{array}$ \\
\hline 5 & 100 & 0 & 0 & 12,4259 & 14,8582 & 10,1893 \\
\hline 10 & 97 & 0 & 27.7 & 8,4599 & 6,524 & 7,2265 \\
\hline 15 & 74.4 & 0 & 25.6 & 8,2454 & 6,1388 & 5,3066 \\
\hline 20 & 100 & 0 & 31.9 & 11,35 & 11,5122 & 4,921 \\
\hline 25 & 100 & 0 & 0 & 13,0109 & 14,7016 & 10,2287 \\
\hline 30 & 100 & 0 & 22.2 & 6,9718 & 8,3454 & 11,3723 \\
\hline 35 & 100 & 0 & 0 & 14,8072 & 10,3998 & 13,7579 \\
\hline 40 & 100 & 0 & 50.8 & 15,5385 & 15,3377 & 11,4969 \\
\hline 50 & 100 & 0 & 28.9 & 12,034 & 8,0505 & 7,6523 \\
\hline 100 & 100 & 0 & 30.5 & 20,9631 & 14,4721 & 9,3868 \\
\hline 150 & 100 & 0 & 24.7 & 18,8065 & 12,5004 & 11,4835 \\
\hline 200 & 100 & 6.1 & 33.1 & 17,5849 & 9,1362 & 11,4391 \\
\hline 300 & 100 & 40 & 24.4 & 12,0051 & 11,201 & 10,447 \\
\hline
\end{tabular}


Продовження табл. 1

\begin{tabular}{|c|c|c|c|c|c|c|}
\hline $\begin{array}{c}\text { Количество } \\
\text { прямоуголь- } \\
\text { ников }\end{array}$ & $\begin{array}{c}\text { ЖА1 } \\
\text { (\%) }\end{array}$ & $\begin{array}{c}\text { ЖА2 } \\
\text { (\%) }\end{array}$ & $\begin{array}{c}\text { ЖА3 } \\
\text { (\%) }\end{array}$ & $\begin{array}{c}\text { Время } \\
\text { работы } \\
\text { ЖА1 (мс) }\end{array}$ & $\begin{array}{c}\text { Время } \\
\text { работы } \\
\text { ЖА2 (мс) }\end{array}$ & $\begin{array}{c}\text { Время } \\
\text { работы } \\
\text { ЖА3 (мс) }\end{array}$ \\
\hline 400 & 100 & 32.9 & 24.1 & 15,4876 & 10,2455 & 10,7168 \\
\hline 500 & 100 & 34.7 & 27 & 24,8693 & 12,1001 & 9,4759 \\
\hline 1000 & 100 & 32.1 & 27.8 & 24,2887 & 11,752 & 14,1803 \\
\hline 1500 & 100 & 32.5 & 28.5 & 26,2156 & 9,1882 & 9,8131 \\
\hline 2000 & 100 & 30 & 28.5 & 23,0852 & 7,644 & 9,9981 \\
\hline 2500 & 100 & 31.5 & 27 & 25,5213 & 10,9643 & 8,9097 \\
\hline
\end{tabular}

Для проведения вычислительного эксперимента генерировались прямоугольники одинаковой ширины и разной длины. При генерации длины была выбрана дисперсия 0.5. Для каждого количества прямоугольников $(5,10$, $15, \ldots)$ генерировалось 1000 наборов длин прямоугольников, которые необходимо разместить на ленте. Прямоугольники размещались с помощью трех алгоритмов, результатами работы алгоритмов представлены процентом получения наименьшей длины среди всех алгоритмов. Также учитывается тот факт, что алгоритмы могут давать одинаковые результаты.

\section{Время работы алгоритмов}

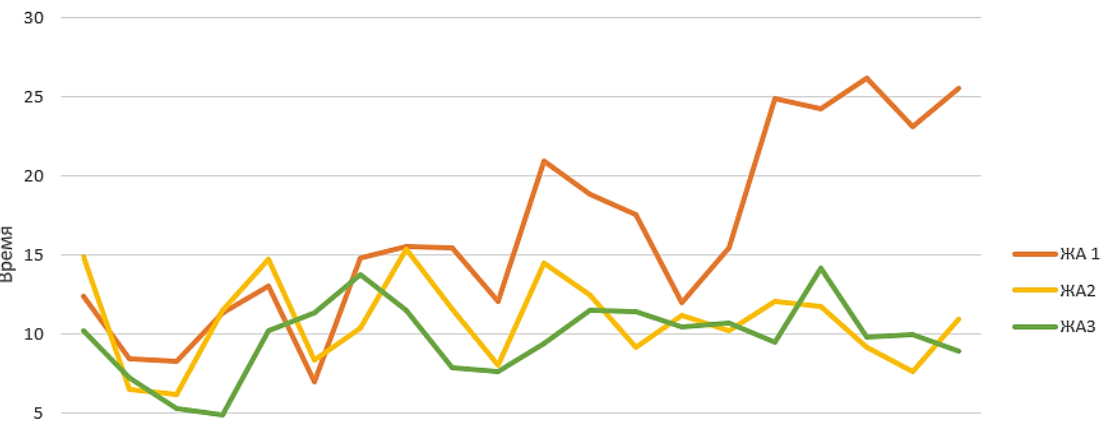

0

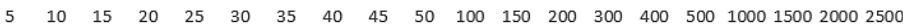

Количество прямоугольников

Рис. 2. Среднее время работы алгоритмов (мс)

Анализ полученных результатов показывает, что алгоритм ЖА1 в $70 \%$ и больше случаях дает лучшее по точности размещение, чем другие алгоритмы. На рисунке представлены графики зависимостей времени работы алгоритмов от количества прямоугольников. Представленные результаты показывают, что ЖА1 работает медленней, чем ЖА2 и ЖАЗ. Это обусловлено тем, что выполняется больше проверок перед размещением очередного прямоугольника. Время работы алгоритмов ЖА2 и ЖАЗ имеют не значительную разницу во времени, по сравнению с алгоритмом ЖА1. При размещении 300 и более прямоугольников алгоритмом ЖА2 количество лучших размещений больше, чем при размещении ЖАЗ. Для получения лучшего решения необходимо использовать ЖА1, но при этом увеличивается время решения. Если необходимо разместить прямоугольники с минимальной 
потерей времени, то рационально применять алгоритм ЖАЗ для задач, с небольшим количеством прямоугольников, но для задач, где количество прямоугольников более 300 - алгоритм ЖАЗ

\section{Выводы.}

В работе представлена задача размещения прямоугольников на полубесконечной ленте при наличии запретных областей - "дырок". Предложены и экспериментально исследованы три жадных алгоритма размещения прямоугольников. Определены различия, преимущества и недостатки алгоритмов. В результате проведения экспериментов выработаны предпочтительные условия использования каждого алгоритма в зависимости от конечной цели: получения преимущества в точности решения задачи или выигрыш во времени.

\section{Список используемых источников:}

1. Сергиенко, И.В., Гуляницкий, Л.Ф. \& Малышко С.А. (1989). О решении задач размещения одного класса. Экономика и математические методы, 560-564. Москва.

2. Конвей, Р.В., Максвелл, В.Л.\& Миллер, Л.В. (1975). Теория расписаний. Москва: Наука.

3. Т., Кормен, Ч., Лейзерсон, Р., Ривест \& К., Штайн. (2015). Алгоритмы: построение и анализ, З-е изд. Москва: ООО «И.Д. Вильямс».

\section{ОСОБЛИВОСТІ ЗАХИСТУ ДАНИХ НА ВЕРСТАТІ 3 ЧПК FANUC}

НАУКОВО-ДОСЛІДНА ГРУПА:

Задвірний Микола Сергійович

здобувач вищої освіти фракультету ринкових, інформаційних та інноваційних технологій Київський національний університет технологій та дизайну

Литвиненко Марина Сергіївна здобувач вищої освіти факультету ринкових, інформаційних та інноваційних технологій Київський національний університет технологій та дизайну

Захарова Марія В'ячеславівна канд.тех.наук, доцент

Київський національний університет технологій та дизайну

Литвиненко Денис Сергійович Управління Державної міграційної служби України в Черкаській області УКРÄ̈HA

Постановка проблеми. На сьогодні представлено великий вибір верстатів з числовим програмним керуванням (далі - ЧПК) різного призначення. Верстати відрізняються між собою покладеними на них функції, але поєднує їх те, що всі вони з числовим програмним керуванням, тому $є$ ризик витоку, 
спотворення чи знищення інформації на них, що призведе до небажаних наслідків.

Метою даної роботи є виявлення особливостей захисту даних на верстаті з ЧПК, що дозволить підвищити рівень безпеки та контролю витоку та зміни даних.

Верстати фірми виробника "FANUC" здебільшого не мають політики розмежування доступу з обліковими записами, як це передбачено в іншого виробника, наприклад: "SIEMENS SINUMERIK", але $€$ можливість змінити доступ до параметрів налаштування [1]. Здійснити це можна за допомогою зміни режиму доступу «Закрити», «Відкрити» та режиму «0», який стоїть по замовчуванню. При режимі «Відкрити» та встановленому перемикачу на панелі керування «EDIT» [2] (на різних моделях ці дії можуть відрізнятись) $є$ можливість здійснювати зміни у налаштуваннях та вносити зміни у параметри верстата, режим «Закрити» забороняє вносити зміни у відповідні параметри. Таким чином, можна заборонити параметри, які оператору непотрібно змінювати для забезпечення безперебійної роботи верстата.

Після здійснення всіх налаштувань на верстат вноситься програма для обробки матеріалу оператором. Вона може бути внесена наладчиком вручну за допомогою написання G-коду [3] або завантажена через носій пам'яті, мережу та підключений персональний комп'ютер. Після здійснення усіх налаштувань верстат готовий до роботи. Надалі оператор розпочинає роботу та працює з вже налагодженим верстатом та програмою на ньому.

Якщо оператор має ключ, що змінює режими доступу, то він отримує можливість вносити зміни у параметри, копіювати, перезаписувати, змінювати, видаляти програму та інші дії, що можуть призвести до непередбачуваних наслідків. Усі дії та зміни, що робляться на верстаті фріксуються у журналах подій, але їх також можна відключити та видалити всі події відповідно. Тому є необхідність забезпечити додаткові рівні захисту для унеможливлення появи таких ситуацій, що можуть спричинити як матеріальні збитки, так і нанести шкоду здоров'ю персоналу.

Метою графіко-динамічної симуляції процесу обробки на верстатах з ЧПК $€$ перевірка програми управління на логічні помилки і їх усунення. В результаті застосування систем симуляції на етапі проектування виявляються можливі пошкодження інструменту, пристосування або верстата. Це має велике значення при виробництві різноманітних продуктів, де наявні програми ЧПК можуть змінюватися без застосування цільового верстата в цеху. У таких випадках можна перевірити на комп'ютері велику кількість програм без переривання процесу обробки для тестування, що значно скорочує час підготовки виробництва.

Пропозиції щодо вдосконалення засобів захисту на верстатах з ЧПК. Проаналізувавши проблему захисту на верстатах, а саме, що будь які зміни у програмі можуть призвести до непередбачуваних наслідків, для покращення рівня захисту необхідно забезпечити фізичне блокування портів та вузлів за допомогою яких, можна здійснити несанкціоновані коригування. Додатково встановити запобіжні пластини на порти для USB-носіїв, карт пам'яті, порту локальної мережі та інших портів, за допомогою яких $є$ можливість під'єднатися до системи керування верстатом. Запобіжна пластина повинна 
бути виготовлена зі стійкого матеріалу, який важко буде пошкодити без відповідного інструменту та закріплений відповідним чином так, щоб перешкодити його зміщенню, зняттю чи пошкодженню без відповідних інструментів, що дасть змогу доступу до тих портів які вона закриває.

Висновки. Запропонований підхід до виявлення особливостей захисту даних на верстаті з ЧПК та пропозиції щодо вдосконалення засобів захисту на верстатах з ЧПК дозволяють забезпечити необхідний рівень безпеки та контролю витоку та зміни даних. Застосування верстатів з ЧПК та їх ефективне функціонування дозволяє значно підвищити продуктивність обробки та поліпшити якість виготовлених деталей.

\section{Список використаних джерел:}

1. Руководство по параметрам fanuc серии: 30i/300i/300is-МОДЕЛЬ A, FANUC серии 31i/310i/310is-MОДЕЛЬ A, FANUC серии 32i/320i/320is-МОДЕЛЬ A, B-63950RU/03. (2003). Вилучено 3 https://cncmanual.com/fanucl

2. Ловыгин, А. А. \& Теверовский Л. В. (2012). Современный станок с ЧПУ и САD/САМ-система. Москва: ДМК Пресс.

3. Морщилов, М. В. (2017). Разработка управляющей программы для станков с ЧПУ: учебнометодическое пособие. Москва: МАДИ.

\section{ЗАСТОСУВАННЯ ІНТЕЛЕКТУАЛЬНОГО АНАЛІЗУ ДАНИХ КОРИСТУВАЧІВ ЗА ДОПОМОГОЮ АЛГОРИТМІВ КЛАСТЕРИЗАЦІї}

Тимошик Максим Вадимович

студент Навчально-наукового інституту інформаційних технологій кафедра Інженерії програмного забезпечення Державний університет телекомунікацій

НАУКОВИЙ КЕРІВНИК:

Онищенко Вікторія Валеріївна доктор технічних наук, профресор, завідувач кафедри

Інженерії програмного забезпечення Державний університет телекомунікацій

УКРӒ̈̈А

Суть і мета технології інтелектуального аналізу даних можна сорормулювати наступним чином: це технологія, яка призначена для пошуку у великих обсягах даних неочевидних, об'єктивних і корисних на практиці закономірностей. Неочевидними закономірностями назвемо закономірності, які не можна виявити за допомогою звичайних методів обробки інформації або експертним шляхом.

Під об'єктивними закономірностями слід розуміти закономірності, які повністю відповідають дійсності, в той час відрізняється від експертної думки, 
яка завжди є суб'єктивною [1]. Під самою кластеризацією маємо закономірність, що $€$ подібною до класифікації (характеристика групи) і відрізняється від неї тим, що самі групи при цьому не задані - вони виявляються автоматично в процесі обробки даних.

Пошук шаблонів проводиться методами, що не є обмеженими рамками апріорних припущень про структуру вибірки і виглядів розподілів значень аналізованих показників.

Важливою особливістю Data Mining [2] є нестандартність і неочевидність ще не знайдених шаблонів. Іншими словами, засоби Data Mining відрізняються від інструментів статистичної обробки даних і засобів OLAP тим, що замість перевірки заздалегідь передбачуваних користувачами взаємозалежностей вони на підставі наявних даних здатні знаходити такі взаємозалежності самостійно і будувати гіпотези про їх характер.

Існують певні напрями використання інтелектуального аналізу даних 3 використанням алгоритмів кластеризації і там де вони показують результат.

Телекомунікації. Телекомунікаційна індустрія була одною з перших, хто застосував інтелектуальний аналіз видобутих даних, і розгорнула численні програми для видобутку даних. Приклади таких програм стосуються маркетингу, виявлення шахрайства та моніторингу мережі. Обмін даними в галузі телекомунікацій стикається з проблемами через розмір наборів даних, послідовний та часовий характер даних та вимоги багатьох додатків у режимі реального часу. Розроблено нові методи та вдосконалено існуючі методи для відповіді на ці виклики. Конкурентний та мінливий характер галузі у поєднанні з тим, що галузь генерує величезні обсяги даних, гарантує, що видобуток даних відіграватиме важливу роль у майбутньому галузі телекомунікацій.

Страхування. Основою до здобуття конкурентної переваги у страховій галузі полягає у визнанні, що бази даних клієнтів при належному керуванні, аналізі та експлуатації $є$ унікальними, цінними корпоративними активами. Страхові компанії можуть розблокувати цінність, що міститься у базах даних клієнта за допомогою сучасної технології інтелектуального аналізу даних. Для аналізу використовується прогнозоване моделювання, сегментація бази даних, аналіз ринкових кошиків та їх комбінації для більш швидкого реагування на важливі для бізнеса питання з більшою точністю. Нові продукти і маркетингові стратегії можуть дозволити страховій фірмі перевести цінність невикористанної зараз інформації в «багатство» передбачуваності, стабільності та прибутку.

Прикладна хімія. Великі бази даних набувають все більшого значення в хімії. Для всеосяжного використання цих баз даних необхідні автоматичні обчислювальні методи. У багатьох актуальних питаннях у всьому світі, таких як дизайн каталітичних матеріалів для збору парникових газів, оптимізація та дослідження відновлюваної енергії ІАД показав прогнозовану потужність для побудови взаємозв'язків між різними внутрішніми і зовнішніми властивостями. Зазвичай, місія процесу ІАД - передбачити (або вивести) ті змінні, які важко отримати за допомогою експериментів чи моделювання за допомогою змінних, які можна легко підставити як вхідні дані. За допомогою добре підігнаної нелінійної фрорми прогнозовані змінні можуть бути швидко виведені за допомогою входів цих незалежних змінних. Інакше кажучи, машинне навчання 
сприяє ІАД для прискорення, оптимізації інженерних процесів, відкриття нових функціональних матеріалів, та розуміння хімічних процесів.

Генна інженерія. Біомедицина $є$ сфрерою багатою на знання і яка має численні стимули кодувати ії в електронному форматі та ділитися нею за допомогою відкритих та підтримуваних у спільнотах баз даних та знань. Вона містить інформацію про послідовність та структуру послідовностей, взаємодії генів та білків, анотацію функцій та онтологій, або генетичні та метаболічні шляхи. Ця інформація може суттєво доповнити будь-який аналіз даних та покращити його результати. Включення додаткових джерел знань у процес аналізу даних може запобігти виявленню очевидних речей, доповнити, використовуючи ці дані, гіпотезу посиланнями на вже запропоновані взаємозв'язки, допоможе уникнути надто впевнених прогнозів i, нарешті, дозволить співвідносити результати аналізу для систематизації знань.

\title{
Список використаних джерел:
}

1. Марченко, О. О.\& Россада, Т.В. (2017). Актуальні проблеми Data Mining: навчальний посібник для студентів факультету комп'ютерних наук та кібернетики. Київ.

2. Петренко, A. I. (2008) Grid та інтелектуальна обробка даних Data Mining. Систем. дослідж. та інфрорм. Технології, (4).

\section{ІННОВАЦІЙНІ МЕТОДИ ВИКЛАДАННЯ ОБЛІКОВИХ ДИСЦИПЛІН: ХМАРНІ ТЕХНОЛОГІї}

\author{
Бабінська Калина Леонідівна \\ викладач облікових дисциплін \\ Криворізький державний комерційно-економічний технікум
}

УКРAÏHA

Глобалізація економіки, зміни в соціально-економічній сфері, переведення іiї на інноваційні технології ставить перед вузами нові виклики - підготовку висококваліфікованих, відповідних сучасним вимогам фрахівців. Це в свою чергу вимагає не тільки зміни змісту предметів, що вивчаються, а й методів і форм організації освітнього процесу. В даний час в світовій спільноті окреслилась тенденція, пов'язана 3 переходом на інший тип освіти інноваційний, а для його ефективної реалізації потрібні інші освітні технології - інноваційні. Впровадження сучасних інноваційних методів навчання дозволять не тільки істотно збільшити інформаційний обмін між викладачем і студентом, а й підвищити якість освіти [1].

Парадигма сучасної освіти - навчити студента працювати з новою інформацією, постійно оновлювати свої знання. Адже робота любого сучасного фахівця - це безперервний пошук знань, вміння ефективно застосовувати їх у своїй повсякденній діяльності. У відповідності з цим інновації в освіті необхідно пов'язувати з інноваційними методами навчання. Суть інноваційних методів полягає в тому, щоб організувати освітній процес у 
формі діалогу, що допоможе студентам навчитися виражати свої думки, аналізувати проблемні ситуації і знаходити ефективні шляхи їх вирішення. Такі методи дозволяють підвищити рівень освіти, розвивають студентів, формують навички та вміння, які будуть використовуватися ними в подальшій професійній діяльності. Вважаємо, що під інноваційними методами викладання облікових дисциплін слід розуміти методи, які розвивають і які розвиваються, тобто це методи, які сприяють до саморозвитку і які створюють умови для повноцінного розвитку всіх своїх учасників. Ці принципи передбачають, що підходи до інновацій у викладанні облікових дисциплін повинні бути самі по собі інноваційними, оскільки традиційні підходи не встигають реагувати на зміни, що відбуваються в бізнес-середовищі [2].

Сучасні тенденції розвитку бізнес-процесів, вимагають проектування адекватних змін цих процесів при підготовці фахівців-обліковців. В даний час інновацію в освіті розуміють, як успішне застосування розроблених технологій.

«Хмарні» технології - це технології, які дозволяють користуватися комп'ютерними ресурсами віддаленого сервера як веб-сервісу через мережу Інтернет на своєму локальному персональному комп'ютері. Тобто всі роботи та обчислення проводяться віддалено, і головним фактором доступності такої технології є наявність інтернету. На даний час існує три моделі клауд-послуг: - laaS (Infrastructure as a Service - інфраструктура як послуга); - PaaS (Platform as a Service - платформа як послуга); - SaaS (Software as a Service програмне забезпечення як послуга). Ці технології дають змогу користувачу використовувати апаратно-програмні ресурси потужних обчислювальних серверів за допомогою веб-інтерфейсу [2].

Отже, впровадження інноваційних методів навчання в освітній процес дозволяє виробляти у студента вміння орієнтуватися в нестандартних ситуаціях, аналізувати виникаючі проблеми, самостійно розробляти i реалізувати управлінські рішення, що в кінцевому підсумку дозволяє істотно підвищити рівень і якість професійної підготовки в цілому.

\section{Список використаних джерел:}

1. Гриднева, Б. О. (2016) Эфффективность применения инновационных технологий в формировании иноязычной профессиональной компетентности студентов. Материалы IV Международной научно-практической видеоконференции (с. 60-61), 30 ноября 2016 г. Тюмень, Российская Федерация.

2. Чижевська, Л.В. (2003) Методика викладання облікових дисциплін : Навчальний посібник. Житомир: Рута. 


\title{
МЕТОДОЛОГІЯ ПОБУДОВИ СИСТЕМ ТЕРМОСТАТУВАННЯ ОБ'ЄКТІВ РАКЕТИ-НОСІЯ
}

\begin{abstract}
Булавка C.C.
аспірант кафедри кондиціонування і рефрижерації Машинобудівного навчально-наукового інституту Національний університет кораблебудування імені адмірала Макарова УКРАЇНА
\end{abstract}

Побудова системи термостатування об'єктів ракетно-космічної техніки, зокрема, космічного апарату (КА) є комплексною і нетривіальною задачею. При використанні у якості методологічної бази алгоритмів, розроблених для побутових систем опалення, вентиляції та кондиціювання повітря (ОВК) виникає необхідність у подальшій спеціалізації ключових підходів відповідно до жорстких вимог підтримання параметрів температури та хімічного складу повітря при значних температурних коливаннях навколишнього середовища, енергетичних і мас-габаритних обмеженнях системи ракети-носія (PH), а також обмеженнях, пов'язаних з впровадженням активної вентиляції на окремих етапах експлуатації PH [1-3]. Необхідність дотримання зазначених вимог призводять до виникнення очевидних протиріч при розробці методології побудови системи термостатування $\mathrm{PH}$, зокрема підобтічного простору (рис. 1).

Відхилення від заданих значень базових параметрів систем контролю КА наведених на рис. 1 у рамках математичної моделі можна покласти за основу наступних цільових функцій:

- відхилення від заданої температури повітря;

- відхилення від заданого рівню вологості повітря;

- відхилення від заданого рівня хімічного забруднення повітря відповідно до окремих складових.

Таким чином, на загальному рівні завдання побудови ефективної системи ОВК для КА може бути вирішено шляхом його зведення до математичної задачі пошуку мінімумів цільових функцій. У рамках даного дослідження даний підхід пропонується покласти у основу методології термостатування об'єктів ракетно-космічної техніки, що проводиться 3 метою забезпечення надійної роботи систем ОВК з мінімальними енергетичними затратами при дотриманні стандартів екологічної безпеки, а також безпеки роботи екіпажу.

Побудова математичної моделі термостатування КА також має включати у себе аналіз конструкції РН взаємне розташування ключових блоків та систем термоізоляції. КА встановлюється під головним обтічником в зоні розміщення корисного вантажу з урахуванням всіх елементів, що можуть виступати, а також можливих відхилень від їх номінального положення у межах допустимої похибки виготовлення. У рамках моделювання також враховуються деформації і пружні зміщення КА і рами кріплення КА при динамічному навантаженні PH [1-3]. Математична модель має враховувати температурні режими, у яких функціонують блоки підобтічного простору та відповідні їм системи термостатування, зокрема:

- система транспортного термостатування підобтічного простору, що використовується для підтримки температурно-вологісного режиму 
підобтічного простору при транспортуванні РН з монтажно-випробувального комплексу (МВК) на стартову позицію;

- система термостатування підобтічного простору повітрям низького тиску, що використовується для подачі термостатуючого повітря безпосередньо після відключення системи транспортного термостатування до моменту відведення транспортно-інсталяційного агрегату (TIA);

система термостатування підобтічного простору повітрям високого тиску, що використовується для подачі термостатуючого повітря під обтічник після відключення системи термостатування низького тиску до моменту старту PH.

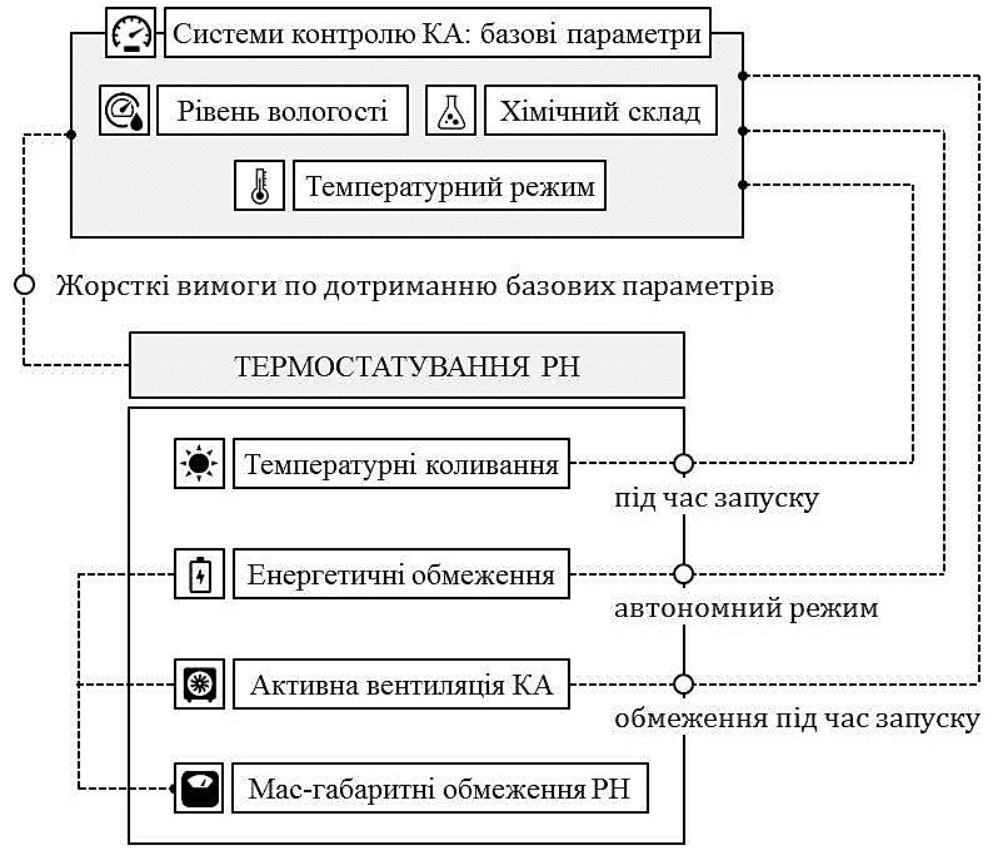

Рис. 1. Діаграма розрахунку системи ОВК для КА Джерело: власна розробка автора

Режими роботи вказаних систем визначаються через такі параметри як клас чистоти технологічного газу, за допомогою якого відбувається термостатування, його швидкість $\left(v_{0} \pm \Delta v\right)$ та температура $\left(T_{0} \pm \Delta T\right)$.

Таким чином, проведене дослідження дозволило сформулювати методологічні рекомендації для побудови систем термостатування об'єктів ракети-носія, зокрема КА та інших модулів підобтічного простору. Запропонований підхід базується на побудові математичної моделі функціонування КА. При цьому відхилення від базових параметрів систем контролю КА пропонується розглядати як цільові фрункції, отримання мінімумів котрих відповідатиме побудові оптимальної системи термостатування. Характерно, що побудова математичної моделі $є$ комплексною задача, що 
включає у себе аналіз особливостей побудови КА, а також систем термостатування відповідно до температурних режимів роботи $\mathrm{PH}$.

\title{
Список використаних джерел:
}

1. Diachenko, M. I., \& Temnov, A. N. (2015). The Investigation Of The Stability Of The Propellant Intake In Carrier Rocket With Monopropellant Rocket Engine. Journal of Dynamics and Vibroacoustics, 2(2), 28-34. doi: 10.18287/2409-4579-2015-2-2-28-34.

2. Система термостатування головного блока ракети: пат. Україна. № 105764 UA; заявл. 03.08.2015; опубл. 11.04.2016, Бюл. № 7. 5 c.

3. Bigun, S. A., \& Khorolsky, M. S. (2019). Peculiarities of Development Testing of Space Rocket Thermostating System Mating Points Hoses. Kosmičeskaâ Tehnika. Raketnoe Vooruženie, 2019(1), 76-81. doi: 10.33136/stma2019.01.076.

\section{НАУКОВИЙ ТЕКСТ ЯК СТРАТЕГІЧНИЙ ЗАСІБ НАУКОВОЇ КОМУНІКАЦІЇ}

\begin{abstract}
Шевчук Ольга
студентка технологічного відділення

Криворізький державний комерційно-економічний технікум
\end{abstract}

НАУКОВИЙ КЕРІВНИК:

Зубченко Наталя Олексіївна

викладачка загальнотехнологічних дисциплін

Криворізький державний комерційно-економічний технікум

УКРӒ̈НA

У новітній інформаційній парадигмі науковий текст системно еволюціонує. Сучасна наукова комунікація, з одного боку, тяжіє до традиційних методів і методик, проте, з іншого, (i це ії принципова ознака) змістовно і формально видозмінюється, демонструючи у такий спосіб зміну самої природи цієї комунікативної площини, бо форма, як відомо, завжди зумовлена змістом і водночас максимально доповнює і розкриває його. Прикметно, що з одного боку, нині існує вже усталена, використовувана впродовж тривалого часу, практика редакційного опрацювання текстів наукових видань, що базується на загально визнаних методах аналізу тексту. 3 іншого, більшість дослідників цього питання одностайні в одному - за зміною природи наукової комунікації та наукового тексту як ії стратегічного засобу - неминучі зміни у системі його редакційного опрацювання [1].

Отже, нині існує кілька основних концепцій редакційного опрацювання тексту наукових видань. Більшість із них враховують окремі характеристики наукового тексту і визначають їх пріоритетними. Вочевидь, частково така практика має право на існування, оскільки для різних жанрів наукових видань, справді визначальними $є$ ті чи інші жанрово-типологічні ознаки. Проте для сучасного науково-інформаційного дискурсу важливо максимально налагодити комунікацію між усіма його учасниками, аби досягти оптимального результату - творення нових наукових парадигм у межах нової читацької свідомості. Безумовно, науковий стиль тяжіє до усталеної стильової традиції, 
96 - Problems and prospects of implementation of innovative research results $\bullet$ Volume 2

тому не слід відмовлятись від напрацювань попередніх теоретиків і практиків, проте нині визначальною особливістю редакційного опрацювання текстів наукових видань $€$ розуміння суті і природи сучасного наукового метадискурсу, зокрема, екстралінгвістичних (позамовних) характеристик, що впливають на його формування, з-поміж яких основна - еволюція новітньої наукової комунікації із максимальним коефіцієнтом корисної дії [2].

\section{Список використаних джерел:}

1. Дубас, Т. (2011). Особливості використання електронних технологій у підготовці наукових бібліотечних видань .Наукові праці Національної бібліотеки України ім. В. І. Вернадського. (с.77-87). Вип. 30.

2. Зелінська, Н. (2003). "Від... конкретних видображень зовнішнього світа... до з'ясування научних дослідів" (універсальна поетика Володимира Домбровського як інструмент аналізу наукового тексту). Вісник Сумського державного університету. Серія Філологічні науки(с. 88-91). № 1.

\section{ОРІЄНТОВНІ НАПРЯМИ ПІДВИЩЕННЯ ЕФЕКТИВНОСТІ СИЛОВОГО ПРИВОДА БУРОВОЇ УСТАНОВКИ 3 ДВИГУНАМИ ВНУТРІШНЬОГО ЗГОРАННЯ}

\section{НАУКОВО-ДОСЛІДНА ГРУПА:}

Лях Михайло Михайлович

канд. техн. наук, профресор, профресор, кафедри нафтогазових машин та обладнання,

Івано-Франківський національний технічний університет нафрти і газу

Михайлюк Василь Володимирович

канд. техн. наук, доцент, доцент, кафедри нафртгазових машин та обладнання Івано-Франківський національний технічний університет нафрти і газу

Дейнега Руслан Олександрович асистент, кафедри нафтогазових машин та обладнання Івано-Франківський національний технічний університет нафрти і газу

Малик Володимир Яркович канд. техн. наук, доцент голова циклової комісії ДВНЗ «Дрогобицький коледж нафти і газу»

Маланин Іван Іванович здобувач вищої освіти інституту інженерної механіки Івано-Франківський національний технічний університет нафрти і газу

УКРАÏHA

В теперішній час в усьому світі велика увага приділяється енергоощадливості, від енергозбереження будуть також покращуватись екологічні показники. В нафтогазовій промисловості процес буріння нафртогазових свердловин $€$ енергозатратними тому в даній роботі основна 
увага звертається на силовий привод бурових установок, а саме підвищення ефективності двигунів внутрішнього згорання за рахунок корисного використання теплових втрат.

В процесі тривалої експлуатації приводів бурових установок виділяється велика кількість теплоти що відводиться у повітря, через систему охолодження двигунів та виводом газів через вихлопні труби. В роботі двигунів внутрішнього згорання більше половини енергії втрачається у вигляді тепла, що $\epsilon$ негативним економічним показником та потребує вирішення поставленої задачі. На рисунку 1 наведено розподіл теплового балансу карбюраторного і дизельного двигунів, де

1 - Теплота еквівалентна ефективній роботі двигуна, \%;

2 - Теплота що виводиться системою охолодження, \%;

3 - Теплота що виводиться з відпрацьованими газами, \%;

4 -Теплові витрати відповідно на тертя і привод механізмів самого двигуна, \%.

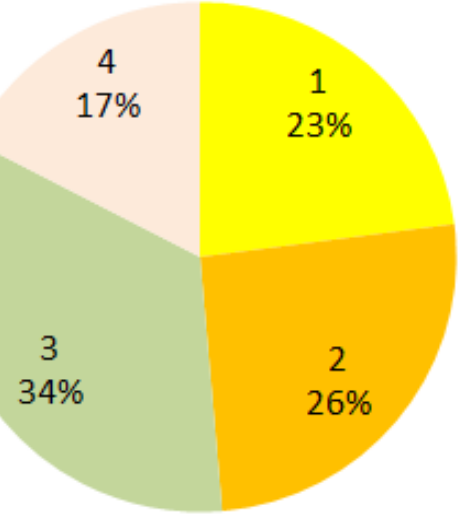

a

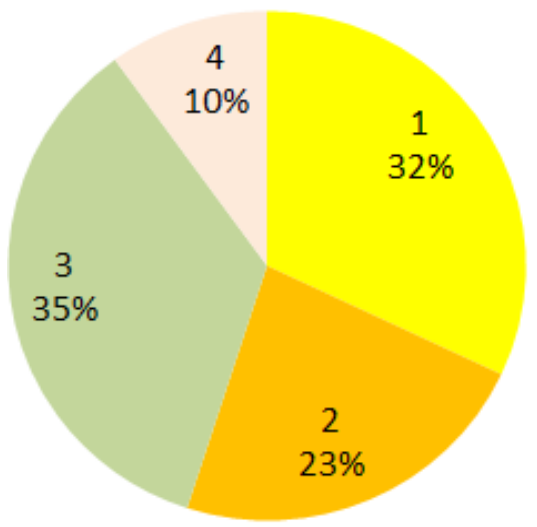

б

Рис. 1. Тепловий баланс

а) - карбюраторного та б) - дизельного двигуна до встановлення спеціалізованого устаткування для ефрективного використання теплового балансу

Найбільш доступна теплова енергія двигунів, яку можна використати для перетворення її в електричну; це:

- теплота що виводиться системою охолодження;

- теплота що виводиться з відпрацьованими газами.

В даному випадку один із варіантів для перетворення теплової енергії в електричну можна використовувати термопари, а також елементи "Пельтьє". Доступні марки даних елементів наведені в таблиці 1 [1].

Таблиця 1

Характеристики елементів «Пельтьє»

\begin{tabular}{|c|c|c|c|c|c|c|}
\hline Назва & Dt, C & $V_{\max }$ & $Q_{\max }$ & $A_{\max }$ & $\begin{array}{c}\text { Габарити, } \\
\text { ммхмм }\end{array}$ & $\begin{array}{c}\text { Товщина, } \\
\text { мм }\end{array}$ \\
\hline TEC1-12704 & 67 & 15,4 & 40 & 4 & $40 \times 40$ & 4 \\
\hline TEC1-12705 & 67 & 15,4 & 41 & 5 & $40 \times 40$ & 4 \\
\hline
\end{tabular}


98 - Problems and prospects of implementation of innovative research results $\bullet$ Volume 2

Продовження табл. 1

\begin{tabular}{|c|c|c|c|c|c|c|}
\hline Назва & Dt, C & $\mathrm{V}_{\max }$ & $\mathrm{Q}_{\max }$ & $\mathrm{A}_{\max }$ & $\begin{array}{c}\text { Габарити, } \\
\text { ммхмм }\end{array}$ & $\begin{array}{c}\text { Товщина, } \\
\text { мм }\end{array}$ \\
\hline TEC1-12706 & 65 & 15,4 & 51,8 & 6 & $40 \times 40$ & 4 \\
\hline TEC1-12708 & 66 & 15,4 & 68,8 & 8 & $40 \times 40$ & 4 \\
\hline TEC1-12712 & 60 & 15,4 & & 12 & $40 \times 40$ & 4 \\
\hline TEC1-12712 & 63 & 15,4 & 106,7 & 12 & $50 \times 50$ & 4 \\
\hline TEC1-12712 & 65 & 15,4 & 113 & 12 & $62 \times 62$ & 4 \\
\hline
\end{tabular}

При використанні елементів «Пельтьє» на блоках двигуна ці елементи можна використовувати за двома призначеннями, тобто в зимовий період буде високий коефріцієнт корисної дії даних елементів для отримання електроенергії та інше призначення, зворотне їх використання для обігріву блоку двигуна для легкого їх пуску при низьких температурах.

Від одного дизельного двигуна 300-350 кВт потужності можна отримати орієнтовно 5-80 кВт·год електроенергії.

Для отримання значних позитивних ефектів у даному напрямку доцільно проводити дослідження та вдосконалювати систему перетворення теплової енергії у електричну.

\section{Список використаних джерел:}

1. Расчет кондеционера на елементах Пельтье? Изъято из https://www.drive2.ru/b/467178368547160947 (дата звернення: 09.12.2019).

2. Елемент Пельтьє: пат. 117282 Україна: МПК Н01L 35/08. № u 20161312 заявл. 22.16.12: опубл. 26.06.17, Бюл. № 12.

3. Процес підвищення коефіцієнта корисної дії термоелектричних приладів: пат. 9169 Україна: МПК 7 HO1L 35/10. № u 2005 01093; заявл. 07.02.2005: опубл. 15.09.05, Бюл. № 9.

4. Маркушин, О.Г. (2012). Система охолодження двигуна. Рівне: РПЛ.

5. Погодин, С.И. (1973). Приведение мощности дизеля к стандартным условиям. - М.: Машиностроение. 


\section{ОСНОВИ ОРГАНІЗАЦІЇ ВИРОБНИЦТВА КУЛІНАРНОЇ ПРОДУКЦІЇ ТА ПРОДУКТІВ ХАРЧУВАННЯ НА ПІДПРИЄМСТВАХ МАСОВОГО ХАРЧУВАННЯ}

Шевчук Ольга

студентка технологічного відділення Криворізький державний комерційно-економічний технікум

НАУКОВИЙ КЕРІВНИК:

Єніна Людмила Іванівна

викладачка технологічних дисциплін Криворізький державний комерційно-економічний технікум УКPAÏHA

На сучасному підприємстві масового харчування кулінарну продукцію виробляють у певній послідовності, починаючи від забезпечення сировиною та обладнанням, інвентарем, енергією та закінчуючи реалізацією готової продукції. Процес перетворення сировини на готову продукцію називається технологічним. Він складається з послідовних стадій: приймання і зберігання сировини; обробка сировини і виробництво напівфрабрикатів; виробництво готової продукції; реалізація готової продукції.

Сировина - це продукти харчування (овочі, риба, м'ясо та ін.), які надходять на підприємство i призначені для обробки, виробництва напівфабрикатів і приготування кулінарної продукції. Напівфабрикати продукти, які пройшли одну або декілька стадій кулінарної обробки (первинну чи теплову), але ще не доведені до кулінарної готовності й призначені для подальшої обробки та приготування страв і кулінарних виробів. Вони ще не придатні для споживання [1].

Залежно від способу обробки напівфрабрикати можуть мати різ ний ступінь готовності. Напівфабрикат високого ступеня готовності - це такий, який пройшов часткову або повну механічну, теплову й хімічну обробку, а також поєднання напівфабрикатів, із яких готують страву чи кулінарний виріб при мінімальних енерговитратах [2].

Страва - поєднання продуктів харчування, доведених до кулінарної готовності, порціонованих, офрормлених і готових для споживання. Кулінарний виріб - харчовий продукт або поєднання продуктів, які доведені до кулінарної готовності, але потребують незначної додаткової обробки (розігрівання, порціонування, оформлення). Готова кулінарна продукція - різні страви, кулінарні та кондитерські вироби. Залежно від організації технологічного процесу, підприємства масового харчування поділяють на ті, в яких технологічний процес здійснюється повністю, а також на заготівельні, доготівельні й на ті, що тільки реалізують готову продукцію. Для здійснення технологічного процесу на підприємстві масового харчування виділяють такі групи приміщень: складські (холодильні камери, склади для овочів, сухих продуктів і тари), призначені для приймання і зберігання сировини та напівфабрикатів; виробничі (заготівельні цехи - овочевий, м'ясний, рибний, 
обробки птиці, м'ясорибний; доготівельні цехи - гарячий і холодний; спеціалізовані цехи - кондитерський, кулінарний, борошняних виробів) для первинної обробки сировини, приготування напівфабрикатів i готової кулінарної продукції. Підприємства з повним технологічним процесом - це підприємства великої потужності, де кулінари обробляють сировину, виробляють напівфабрикати і готову продукцію для реалізації в своїх залах, а також у буфретах і магазинах. До них належать комбінати харчування, ресторани, комплексні підприємства масового харчування. Ці підприємства повинні мати складські та виробничі приміщення (цехи).

\title{
Список використаних джерел:
}

1. Ксенюк, М.П. \& Сиза, О.І. (2014). Основи кулінарної майстерності. Чернігів: ЧНТУ. 2014.

2. Стахмич, Т.М. \& Пахолюк, О.М. (2008). Кулінарне мистецтво. Київ: Грамота.

\section{ПЕРЕВАГИ I ПЕРСПЕКТИВИ ВИКОРИСТАННЯ ХМАРНИХ ТЕХНОЛОГІЙ У ОСВІТНЬОМУ ПРОЦЕСІ}

\author{
Лисенко Ніна Петрівна \\ викладач технологічних дисциплін \\ Криворізький державний комерційно-економічний технікум
}

УКРАÏHA

Наразі в україномовному сегменті мережі Інтернет найбільшою популярністю серед освітян користуються сервіси хмарних обчислень таких корпорацій, як Microsoft та Google. Саме вони дають змогу організувати швидке впровадження технологій хмарних обчислень у навчально-виховний процес. Так, Microsoft пропонує низку інструментів, що базуються на спільній взаємодії викладача та студента (пакет Microsoft Office 365), а саме: - систему електронної пошти; - інтерактивні календарі; - контакти Outlook Line; - вебдодатки та архіви OneDrive; - систему обміну миттєвими повідомленнями Lync Online, міні-сайти тощо. Служба Microsoft Office 365 може підтримувати як персональне використання онлайнових інтерактивних додатків, так i корпоративне десятками тисяч користувачів [1].

У свою чергу, Google для впровадження в освітній процес хмарних технологій пропонує сучасний інструмент побудови навчальних порталів службу Google Apps for Education. Google Apps - це набір хмарних служб, які допомагають користувачам послуг інформаційного простору продуктивно спілкуватися незалежно від місця перебування та характеру технічних пристроїв. Як свідчить практика, нескладні в налаштуванні, використанні й управлінні інструменти (електронна пошта, календар, онлайн-документи та інтерактивні додатки) дають змогу користувачам зосередитися на тому, що дійсно важливо [2] для їх взаємодії в інформаційному освітньому просторі.

Основними перевагами використання хмарних сервісів $€$ мінімальні вимоги до апаратного забезпечення: хмарні технології не вимагають витрат на 
придбання та обслуговування спеціального програмного забезпечення (доступ до додатків можна отримати через вікно будь-якого браузера); вони спроможні підтримувати всі операційні системи і клієнтські програми, що використовуються активно; всі інструменти хмарних технологій - безкоштовні [1].

Оскільки Microsoft та Google постійно вдосконалюють свої службові сервіси хмарних технологій, потужний інструментарій та інноваційний функціональний потенціал освітніх хмар є доступним сучасному педагогові, а отже, сприяє підвищенню професійного інтересу до їх використання в педагогічній діяльності [2]. Звертаючись до послуг мережі Інтернет з метою вербальної комунікації, викладачі обмінюються зі студентами навчальними матеріалами, а з колегами - професійним досвідом.

Ураховуючи, що з хмарними сервісами можна працювати не лише через комп'ютер, а й інші ґаджети (планшети, смартфони), підвищується ступінь мобільності користувачів послугами інформаційного освітнього простору, адже для хмарних сервісів не важливо, яка операційна система встановлена на ґаджеті, тому що сервіси знаходяться на віддаленому сервері та не потребують додаткового встановлення на пристрій студента або викладача.

Отже, аналіз переваг і перспектив використання хмарних технологій у освітньому процесі дає підстави констатувати, що мережева хмара відкриває небачені можливості як для студентів, так і педагогів за умови їх готовності до відкритої взаємодії.

\section{Список використаних джерел:}

1. Воронкін, О. С. «Хмарні» обчислення як основа формування персональних навчальних середовищ. Матеріали II Міжнародної науково-практичної конференції «FOSS Lviv - 2012» (с.143-146). 26-28 квітня, 2012 р. Львів, Україна.

2. Гриценко, В. Г. Формування навчального середовища з використанням соціальних хмарних сервісів. Хмарні технології в освіті : матеріали Всеукраїнського науково-методичного інтернет-семінару (с.29-30). 21 грудня ,2012 р. Кривий Ріг, Україна : Видавничий відділ КМІ, 2012.

\section{РОЗРОБКА ТЕХНОЛОГІЇ ТА ОБЛАДНАННЯ ДЛЯ ТЕРМІЧНОЇ ОБРОБКИ МЯСНИХ ПАШЕТІВ}

НАУКОВО-ДОСЛІДНА ГРУПА:

Приліпко Тетяна Миколаївна

доктор с-г. наук, професор

Подільський державний аграрно-технічний університет

Гончар Валентин Іванович

канд. с-г. наук, доцент

Подільський державний аграрно-технічний університет

Пустова Наталія Володимирівна

канд. с.-г. наук, доцент

Подільський державний аграрно-технічний університет 
Problems and prospects of implementation of innovative research results $\bullet$ Volume 2

\section{Калинка Андрій Казимирович}

канд. с.-г. наук, с. н. с

Буковинська державна сільськогосподарська дослідна станція НАAН

УКРАÏHA

При виборі температури і тривалості нагрівання консервів в автоклавах виходять, в першу чергу, з того, що правильно встановлений режим стерилізації повинен забезпечити мікробіологічну стабільність консервів. Режим стерилізації повинен гарантувати належну ступінь пригнічення мікроорганізмів, потенційно шкідливих для здоров'я людини, а також тих, які можуть стати причиною псування консервів під час зберігання. При цьому слід враховувати, що нагрівання повинно бути по можливості мінімальним для забезпечення високих органолептичних властивостей та харчової цінності готових продуктів [1].

Для стерилізації консервів, в даний час, відомі апарати різних конструкцій - як періодичної, так і безперервної дії. У порівнянні з стерилізаторами і пастеризаторами безперервної дії автоклави мають ряд суттєвих недоліків, основними з яких є: труднощі створення рівномірного температурного поля, що приводить до вимушеного збільшення тривалості стерилізації; трудомісткість операцій 3 технологічного та технічного обслуговування; неможливість забезпечення поточності переміщення консервів, що призводить до негарантованої обробки всієї виробленої продукції [2].

Незважаючи на такі значні недоліки, автоклави займають домінуюче місце в стерилізаційному і пастеризаційних обладнанні вітчизняної та світової консервної промисловості через притаманного цьому обладнанню універсалізму [3, 4].

У консервній промисловості застосовуються вертикальні і горизонтальні автоклави періодичної дії [1], які дозволяють стерилізувати практично будь-які харчові продукти, розфрасовані в будь-які види тари. При стерилізації консервів в автоклавах можливо вторинне обсіменіння мікроорганізмами консервів в процесі охолодження. Розміри мікробів досить малі. Об'єм звичайного мікроба «Коки» складає $10^{-12} \mathrm{~cm}^{3}[3]$. Допуск при машинній обробці банок має величину порядку 0,025 мм, тобто мікроби можуть бути в $10 \ldots 100$ разів менше цих величин. Тому можливе утворення в швах незначних нещільностей, достатніх для проникнення мікробів. [5],

Метою експериментальних досліджень $€$ підтвердження теоретичних передумов процесу стерилізації консервованого м'ясного паштету та визначення оптимальних режимних параметрів досліджуваного обладнання за умови підвищення якісних характеристик вихідної продукції.

Запропонована оптимізація режимних і конструктивних параметрів вертикального двокорзинного автоклаву, шляхом введення у систему технічного забезпечення - теплообмінника змішування і зміни напрямку подачі гострої пари, забезпечує найкращі умови для видалення повітря, скорочується час продувки, зменшуються втрати пари, виключається подача перегрітої пари в автоклав і необхідність нагрівання і охолоджування проміжного теплоносія води. Завдяки цьому, можна швидко почати процес інтенсивного підведення тепла до банок, що дозволяє скоротити час нагріву і витрату пари $[4,5]$. 
У результаті цього зросте ефективність апарату, а завдяки зменшенню часу впливу тепла і вирівнюванню умов нагрівання банок в різних зонах автоклава, більшою мірою збережеться якість продуктів при консервуванні. У цьому випадку, подача пари знизу в деякій мірі компенсує нерівномірність нагрівання шарів банок, що виникла при подачі пари зверху під час продувки. Зростання температури в автоклаві триває до досягнення температури стерилізації. У цей час відбувається нагрів банок насиченою парою, який характеризується постійністю температур і коефіцієнта тепловіддачі до всіх банків в кожен момент часу. При досягненні температури стерилізації, тиск в автоклаві досягає 0,7 - 1,3 атм. Подальше зростання температури обмежують, але тиск необхідно підвищувати. Для цього в автоклав по трубопроводу починають подавати повітря. По трубопроводу для підігріву повітря, подають деяку кількість пари. Повітря, змішуючись 3 парою в трубопроводі, підігрівається, його температура підвищується, після проходу через теплообмінник, а потім повітря подається над сіткою. Подача повітря зверху банок забезпечує його рівномірний розподіл у всьому об'ємі корпусу. 3 початку подачі повітря зростає температура кипіння конденсату (внаслідок підвищення тиску), яка починає перевищувати температуру стерилізації. Тому, якщо продовжувати здійснювати подачу пари весь час зверху, то верхній шар банок перегрівається. Крім того, при постійній подачі пари зверху почне збільшуватися концентрація повітря біля нижніх шарів банок. Експериментально визначено, що циклічність перемикання вентилів становить 5-10 хвилин, причому час подачі пари в верх корпуса менше часу подачі пари в низ корпусу. Повітря подають в мінімально можливих кількостях, що забезпечують збереження тари, що дозволяє в мінімальному ступені збільшити температуру кипіння конденсату і забезпечити тим самим достатню рівномірність нагріву консервів. Наприкінці стерилізації подають додаткову порцію повітря і з цього моменту тиск в автоклаві дещо перевищує тиск у банках, що оберігає тару від деформації, при конденсації пари, після подачі охолоджуючої води і виключає кавітацію в насосі. Випускають конденсат 3 корпусу і частково із ємкості. Надлишок конденсату виливають, залишаючи його на рівні, що забезпечує стійку роботу насоса.

Випробування автоклава проводили у виробничих умовах на ТОВ «Камянець - Подільський м'ясокомбінат». Після завантаження автоклава консервами - паштет «Подільський» в жерстяних банках №1 масою нетто 100 гр., проводили його продувку шляхом подачі у верхню частину автоклава пари температурою $110{ }^{\circ} \mathrm{C}$, протягом 2 хв., до початку виходу з автоклава середовища 3 температурою $78{ }^{\circ} \mathrm{C}$, а потім збільшували температуру всередині апарата протягом 20 хв. парою, що подається через воду в теплообміннику, до досягнення температури стерилізації $115{ }^{\circ} \mathrm{C}$. Після встановлення цієї температури створювали в автоклаві тиск 2,5 атм. повітрям, яке попередньо підігрівалося, шляхом пропускання його через конденсат у теплообміннику. Витримування консервів при температурі $115^{\circ} \mathrm{C}$ проводилося протягом 30 хв. (в інших випадках час стерилізації тривав 40 хв. або 50 хв.). Перед охолодженням консервів випускали надлишок конденсату і вели охолодження зрошенням банок сумішшю конденсату і води з початковою температурою $65^{\circ} \mathrm{C}$, яка поступово знижувалася до $29^{\circ} \mathrm{C}$, шляхом додавання 
холодної води. Охолодження консервів проводили протягом 20 хв. Тиск в автоклаві під час охолодження підтримувався, близько 2,5 атм., шляхом подачі повітря. Під час підйому температури і стерилізації пару подавали поперемінно зверху і знизу автоклава з циклічністю. Протягом усього періоду продувки, підйому температури і стерилізації, пара, що подавалась в автоклав, проходила через теплообмінник, при кипінні в ньому води (конденсату), маса якої склала:

$$
m=\frac{k\left(w t\left(I-I^{\prime}\right)\right)-c m_{t} \Delta t}{I^{\prime}-I_{v}}=\frac{12\left(41 \cdot 290\left(2754 \cdot 10^{3}-2705 \cdot 10^{3}\right)\right)-43,2 \cdot 1180 \cdot 100}{2705 \cdot 10^{3}-2100 \cdot 10^{3}}=34 \kappa 2
$$

Мінімальна ємність збірника конденсату була визначена і склала:

$$
V=Q(n+3) \frac{\sqrt{2 H}}{g}+V_{k}=\frac{15}{360}(62+3) \frac{\sqrt{2 \cdot 0,031}}{9,8}+0,12=0,15 \mu^{3}
$$

Після закінчення охолодження кришку автоклава відкривали, корзини 3 банками вивантажували і проводили огляд консервів. Температуру всередині банок, розміщених у різних зонах автоклава і в автоклаві, вимірювали за допомогою голчастих термопар і приладу фірми «Еллаб». Вимірювання тиску в автоклаві проводилося за допомогою манометра. Виробничі дослідження підтвердили зменшення витрат пари і води при пароповітряній термообробці і скорочення часу стерилізації до 9 хв. порівняно зі стерилізацією у воді. Скорочення часу нагрівання дозволяє більшою мірою зберегти біологічну цінність консервів і підвищити їх якість.

Стерилізація є найважливішим процесом, що визначає якість консервів. Консерви стерилізували при температурі $115{ }^{\circ} \mathrm{C}$. При таких високих температурах значно зростає швидкість гідролізу складових компонентів м'яса, у тому числі білків, а також відбувається розпад продуктів гідролізу, в тому числі амінокислот. Ступінь гідролізу зростає з підвищенням температури і збільшенням тривалості стерилізації. При стерилізації відбувається більш глибока деструкція білків. Зі збільшенням теплового навантаження кількість вільних амінокислот зростає з 8,26 до 10,2 г/100г, що свідчить про зростання швидкості гідролітичного розпаду білків у продукті при збільшенні тривалості нагрівання.

При нагріванні у вологому середовищі до температури вище $100 \mathrm{C}$ прискорюються процеси гідролізу тригліцеридів і насичення подвійних зв'язків радикалів жирних кислот гідроксильними групами. Внаслідок часткового розпаду жиру збільшується кількість вільних жирних кислот. При збільшенні теплового навантаження - стерилізаційного ефеекту з 4 до 8 ум. хв. зростає кількість жирних кислот у продукті з 12,5 до 14,6 \%.

Отже оптимізація режимних і конструктивних параметрів автоклава забезпечує найкращі умови для видалення повітря, скорочується час продувки, зменшуються втрати пари, виключається подача перегрітої пари в автоклав і необхідність нагрівання і охолоджування проміжного теплоносія води. Шляхом математичного аналізу розробити віртуальні моделі рецептур 
консервованих паштетів. Провести порівняльний аналіз рецептурного складу та теплових режимів аналогічних паштетних продуктів.

\title{
Список використаних джерел:
}

1. Прянишников, В. \& Леонова, А. (2008). Современные технологии производства консервов из м'яса птицы. Птицефабрика, (5), 32-33.

2. Приліпко Т.М. \& Куций В.М.(2013). Розробка технології виробництва паштетів із м'яса індиків. Актуальні проблеми харчової промисловості: тези доповідей Всеукраїнської науково-техніч. конф., 8-9 жовтня 2013р. / ТНТУ ім. Івана Пулюя. Тернопіль, 166-168.

3. Пат. № 84152 Україна, МПК ${ }^{9}$ А23В4/00.Режим стерилізації консервованих паштетів / Приліпко Т.М., Куций В.М.; заявник і патентовласник Куций В.М. № u201304964 ; заявл. 18.04.2013 ; опубл. 10.10.2013, Бюл. № 19/2013.

4. Паштет консервований із м'яса індиків «Подільський» : ТУ У 10.122769675-001:2013.(2013). Львів : ТК № 132 Держспоживстандарту України. 10 с. (Технічні умови).

5. Hartmann, C., Mathmann, K \& Delgado, A. (2006). Mechanical stresses in cellular structures under high hydrostatic pressure. Food Science and Emerging Technologies, 7, 12, 1-12.

\section{СТРУКТУРА ВИРОБНИЦТВА ХАРЧОВОЇ ПРОДУКЦІї}

\author{
Вознесенський Дмитро \\ студент технологічного відділення \\ Криворізький державний комерційно-економічний технікум
}

НАУКОВИЙ КЕРІВНИК:

Єніна Людмила Іванівна

викладачка технологічних дисциплін

Криворізький державний комерційно-економічний технікум

Україна

Для виробництва продукції певного асортименту або виконання тієї чи іншої стадії технологічного процесу на підприємствах масового харчування організовують цехи. Цех - це виробничий підрозділ підприємства, оснащений від повідним обладнанням, інструментами, інвентарем. У цехах обробляють сировину, готують напівфабрикати або випускають готову продукцію. Цехи поділяють на заготівельні (овочевий, м'ясний, рибний, обробки птиці), доготівельні (гарячий, холодний), спеціалізовані (кон дитерський, борошняних виробів, кулінарний). На доготівельних підприємствах організовують цехи для доробки напівфабрикатів і обробки зелені. Крім цехів на виробництві передбачено допоміжні приміщення для миття кухонного посуду, миття i зберігання тари для напівфабри катів (функціональних місткостей), для нарізування хліба тощо. Взаємозв'язок окремих підрозділів підприємства (цехи, допоміжні приміщення), задіяних у виконанні однієї чи декількох стадій 
технологічного процесу, визначає структуру виробництва. Підприємства масового харчування можуть мати цехову й безцехову структуру виробництва, залежно від їхнього типу та потужності. Цехова структура виробництва передбачена на великих підприємствах (ресторани, їдальні), які працюють на сировині, і заготівельних підприємствах (фабрики заготівельні, кулінарні фабрики, їдальнізаготівельні). У кожному цеху організовують технологічні лінії. Технологічною лінією називається ділянка виробництва, оснащена необхідним обладнанням для здійснення технологічного процесу.

Роботу цехів очолює начальник, у підпорядкуванні якого пере буває одна або декілька бригад. Цехова структура виробництва сприяє поопераційному поділу праці та її спеціалізації, ефективно му використанню обладнання. Безцехова структура виробництва характерна для підприємств із невеликою потужністю, i тих, які працюють на напівфабрикатах і мають невелику виробничу програму й обмежений асортимент продукції власного виробництва (спеціалізовані закусочні, їдальні-доготівельні та ін.). На таких підприємствах практикують функціональний розподіл праці, тобто всі операції виконують одна або дві виробничі бригади, які підпорядковуються завідуючому виробництвом.

Перша ділянка призначена для приготування гарячих напоїв (чаю, кави, какао, шоколаду та ін.), солодких страв, гарячих закусок, других гарячих страв, теплової обробки продуктів, які використовують для приготування холодних закусок, випікання деяких борошняних виробів; друга ділянка - для приготування холодних закусок, солодких страв, освіжаючих напоїв, порціонування, оформлення і відпускан ня готової продукції. Для виконання певних технологічних операцій із приготуван ня напівфабрикатів або готових страв у цеху організовують робочі місця. Робочим місцем називають ділянку виробничої площі цеху, на якій розміщене обладнання (механічне, теплове, холодильне, немеханічне, ваговимірювальне), інвентар, інструменти, пристрої, по суд, тара, необхідні працівникові для виконання окремих технологічних операцій.

\section{Список використаних джерел:}

1. Ксенюк, М.П., Сиза, О.І. (2014) Основи кулінарної майстерності. Чернігів: ЧНТУ. 2014.

2. Стахмич, Т.М., Пахолюк, О.М. (2008) Кулінарне мистецтво. Київ: Грамота. 


\title{
TEOPEТИЧНI ОСНОВИ FOODPAIRING
}

\author{
Лінова Ольга \\ студентка технологічного відділення \\ Криворізький державний комерційно-економічний технікум \\ НАУКОВІ КЕРІВНИКИ: \\ Лисенко Віталій Сергійович \\ методист технікуму \\ Криворізький державний комерційно-економічний технікум
}

Пислиця Альона Іванівна

викладачка дисциплін з організації виробництва та обслуговування

в закладах ресторанного господарства

Криворізький державний комерційно-економічний технікум

УКРÄ̈̈A

За допомогою Foodpairing ми намагаємося зробити цей процес відкритим. Наприклад, пара - шоколад і курка - може здатися дивною, але якщо ви поїдете в Мексику, то побачите, що там це дуже поширена комбінація. Так що, думаю, творча кулінарія - це готовність вводити нові поєднання. Знайомлячи людей з Foodpairing, ми говоримо їм: коли ви починаєте готувати, використовуючи наші дерева, не хапайтеся за найдивніші комбінації.

Просувайтеся крок за кроком і, коли навчитеся поєднувати різні компоненти в салатах, переходьте до поєднання оселедця і шоколаду. Вам вирішувати, який кухар з вас вийде. Якщо вас більше приваблюють традиційні поєднання, почніть з приготування рецептів з веб-сайту, а потім з головою кидайтеся в екстрим. Іноді студенти-кухарі переймаються надмірним ентузіазмом i починають змішувати все підряд. Мета не в цьому. Пробуйте нове поступово. Головна ідея застосування фудпейрінга - посилити аромат вихідних продуктів завдяки новим варіацій [1].

Foodpairing - метод, що допомагає визначити, які продукти утворюють ідеальні пари за допомогою вивчення їх ароматичних компонентів.

Цей метод базується на принципах хімічного аналізу інгредієнтів, продуктових виробів і напоїв для виявлення переліку ароматів, присутніх в кожному з них. А потім об'єднує тільки схожі по ароматичним якостям продукти, що сприяє створенню нових комбінацій, які носять інноваційний характер, не схильні до впливу і обмеження культурою і традиційними уявленнями про сполучуваність продуктів.

Методологія Foodpairing відкриває цілий новий світ всіляких комбінацій продуктів харчування. Більш того, новий напрямок в змозі забезпечити теоретичну основу для традиційно усталених сполучень продуктів харчування. Адже не випадково переважна більшість традиційних сполук таких, як бекон і сир, спаржа і вершкове масло, мають загальні ключові ароматичні компоненти.

Аналіз існуючої технології показав, що метод Foodpairing сформувався зовсім недавно як синтез кулінарії і науки. На основі аналізу інформації іноземних джерел можна зробити висновок про актуальність наукового підходу 
до поєднання ароматів як інноваційного методу створення кулінарної продукції [2].

Проведені дослідження підтверджують широко обговорювану гіпотезу про поєднанні продуктів за ключовими ароматичним компонентів і сприяють утворенню судження про якнайшвидше входження даної методики в оборот підприємств ресторанного господарства і в побутову сферу. Крім того, використання технології Foodpairing дозволяє залучити більшу кількість споживачів за рахунок її специфічності, що, безсумнівно, позитивно позначиться на роботі підприємств ресторанного господарства.

\section{Список використаних джерел:}

1. Бернар, Л. (2013) Процесс фудпейринга начинается с анализа ароматических составляющих продуктов. ХлебСоль (21-30). № 1.

2. Долгополова, С.В. (2019) Нові кулінарні технології Москва: «Издательский дом» Ресторанные ведомости». 376с.

\section{УДОСКОНАЛЕННЯ АЛГОРИТМУ ФІЛЬТРАЦІЇ ЦИФРОВИХ ЗОБРАЖЕНЬ ЗА ДОПОМОГОЮ СПЛАЙНОВОГО ФІЛЬТРУ В СЕРЕДОВИЩ МАTLAB}

Кривенко Ігор Михайлович студент кафедри Інженерії програмного забезпечення Державний університет телекомунікацій

НАУКОВИЙ КЕРІВНИК:

Онищенко Вікторія Валеріївна д-р. техн. наук, професор, завідувач кафедри Інженерії програмного забезпечення Державний університет телекомунікацій УКРАÏHA

Головна ціль покращення полягає в такій обробці зображення, щоб результат виявився більш придатним з точки зору конкретного застосування. Слово конкретне $є$ ключовим, оскільки воно з самого початку встановлює, що методи, які ми будемо застосовувати, в значній мірі проблемно-орієнтовані. Так, наприклад, метод, який добре підходить для покращення рентгенівських зображень, не обов'язково є найкращим для обробки знімків Марса, які були передані космічним апаратом.

Одним із основних типів інформаційних систем, що використовують цифрові дані, є рентгенографрічні системи [1]. Основними завданням обробки $є$ усунення дефектів, зменшення впливу спотворень і шумів, перетворення зображення в зручне для спостереження лікарем-рентгенологом. Особливе, важливе значення мають методи обробки рентгенівських зображень. Ефективність поставлення правильного діагнозу, виявлення на початкових стадіях тяжких хвороб значною мірою досягається якістю цифрових матеріалів. 
Методи покращення зображень в основному представляють собою евристичні процедури, призначені для такого впливу на зображення, який дозволить потім використовувати переваги, пов'язані з психофізичними особливостями зорової системи людини. Наприклад, процедура підсилення контрасту розглядається, як метод покращення, оскільки в результаті її застосування зображення, в першу чергу, стає більш приємним для ока, тоді як процедура обробки змазаного зображення, базується на застосуванні оберненого оператора і розглядається як метод відновлення [4].

Першочерговим завданням системи являється покращення якості зображення. Проблема шумоподавлення являється однією із найбільш актуальних і розповсюджених проблем в області обробки зображень. Найбільш розповсюдженими видами шумів являються Гауса і імпульсні шуми, а також їх комбінації [2-3].

Для цієї проблеми і проблеми шумоподавлення в цифрових знімках загалом, було розроблено сплайновий та медіанний фільтри зображень. Було проведено тестування розроблених фільтрів на штучно зашумлених зображень за розподілом Гауса. За основу в порівнянні двох фрільтрів було взято середньоквадратичне відхилення:

1. Рівень фільтрації медіанного фрільтра:

$\operatorname{Std} 2(X-D)=10,0016$ - початкового і зашумленого зображення;

$\operatorname{Std} 2(X-M F)=4,4876-$ початкового і відфільтрованого.

2. Рівень фільтрації сплайнового фільтра:

$\operatorname{Std} 2(X-D)=9.9967-$ початкового і зашумленого зображення;

$\operatorname{Std} 2(X-F)=4.3952$ - початкового і відфрільтрованого.

3 огляду на сучасний стан в сфері відновлення зображень з шумами, використання сплайнового фільтру є доцільним і більш ефективним ніж використання медіанного фрільтру.

Сплайновий фільтр є більш гнучким фрільтром, оскільки дозволяє вибрати поліном який найефективніше підходить до відновлення конкретного зображення.

\section{Список використаних джерел:}

1. Гонсалес, Р. \& Вудс, Р. (2005). Цифровая обработка изображений Москва: Техносфрера. 2005. $1072 \mathrm{c}$.

2. Грузман, И.С., Киричук, В. С. \& Косых, В. П. (2000). Цифровая обработка изображений в информационных системах: Учебное пособие / Новосибирск: НГТУ, 2000. 168 с.

3. Богнер, Р. \& Константинидис, А. (1976). Введение в цифрровую фильтрацию. Москва: Мир.

4. Файнзильберг, Л. С. (2002). Частотно-избирательная фильтрация в информационных технологіях обработки сигналов. УСиМ, (2), 54-59. 


\title{
ФЕРМЕНТАТИВНА АКТИВНІСТЬ ШВИДКОЗАМОРОЖЕНОГО ДЕСЕРТУ ФУНКЦІОНАЛЬНОГО ПРИЗНАЧЕННЯ НА ОСНОВІ ГАРБУЗА
}

\author{
Заболотна Альона Вадимівна \\ канд. с.-г. наук, ст. викладач кафедри технологій харчових продуктів \\ Уманський національний університет садівництва \\ Заболотний Олександр Іванович \\ канд. С.-г. наук, доцент кафедри біології \\ Уманський національний університет садівництва \\ Лобода Аліна Юріївна \\ студентка \\ Уманський національний університет садівництва \\ Україна
}

Десерти - відома група висококалорійних харчових продуктів, що традиційно користуються попитом. Особливістю цієї продукції $\epsilon$ незбалансованість хімічного складу, висока калорійність, значний вміст жирів і вуглеводів, відносно низький вміст білку та недостатня кількість біологічно активних речовин. Але, крім того, ряд солодких страв містить також вітаміни, мінеральні солі, необхідні для організму людини.

Асортимент солодких страв надзвичайно широкий. Різноманітна і сировина, що застосовується для приготування солодких страв. Для багатьох страв основною сировиною служать плоди і ягоди в свіжому, консервованому, замороженому або сушеному вигляді.

Особливо цінуються свіжі плоди, так як в них містяться легко засвоювані цукри - глюкоза і фрруктоза. Крім того, в них $є$ фрруктові кислоти (яблучна, лимонна, винна), з'єднання заліза, вітамінів і фрерментів. Виключне значення в харчуванні набувають плоди і ягоди завдяки вмісту в них вітамінів А, B1, C, P, особливо вони багаті вітаміном С.

Сучасні умови виробництва продуктів ставлять нові завдання 3 удосконалення технології їх отримання і поліпшення споживчих характеристик. Досягнення таких результатів неможливо без використання спеціальних речовин (харчових добавок), що дозволяють створювати безпечні та якісні продукти, з поліпшеними функціонально-технологічними властивостями [2].

Одним 3 найбільш перспективних напрямків розвитку харчової промисловості в даний час $є$ розробка продуктів здорового харчування, в т.ч. збагачених функціональними інгредієнтами. 3 огляду на існуючі тенденції розвитку ринку харчових продуктів, виробники працюють над розширенням асортиментного ряду шляхом включення функціональних інгредієнтів до складу традиційних рецептур [1].

Одним 3 ефективніших способів перероблення плодів і овочів, $€$ заморожування [1]. Загальновизнаними перевагами швидкозамороженої плодоовочевої продукції є також те, що вищезазначені продукти практично не містять неїстівних частин. Вони практично - безвідходні, окрім пакування [3].

Важливу роль у харчуванні людини відіграють овочі. Їхня користь обумовлена хімічним складом, енергетичною і біологічною цінністю, фізіологічною та лікувально-профрілактичною дією [4]. Серед овочевих культур, 
які вирощують в Україні, гарбуз займає чільне місце. Цей овоч належить до баштанних культур і нараховує велику кількість видів.

Принциповою відмінністю запропонованих продуктів $€$ використання в рецептурах сировини з високим вмістом природних антиоксидантів - вітаміну C, $\beta$-каротину, поліфенольних речовин, раціональне поєднання яких гарантує повноцінне забезпечення поживними і біологічно цінними речовинами всіх життєвоважливих систем організму, включаючи імунну.

Відомо, що одним із основних чинників під час переробки плодів та овочів, які впливають на ступінь зберігання вітамінів, каротиноїдів та інших. біологічно активних речовин, у тому числі під час заморожування $\epsilon$ інактивація окиснювальних ферментів.

Активність ферментів окисно-відновної дії визначали на різних етапах зберігання продукції - у свіжозаморожених зразках, після холодильного зберігання протягом 1-9-ти місяців за Х.М. Починком.

В результаті досліджень було встановлено, що активність окисновідновних фрерментів зростає під час зберігання десерту у всіх варіантах. Найбільший показник активності спостерігається в зразках на кінець терміну зберігання, а відповідно до варіантів у контрольному зразку.

Аналізуючи свіжозаморожені зразки можна відмітити, що активність поліфенолоксидази в порівнянні з контрольним зразком у варіанті, що передбачає додавання до гарбуза хурми і заміну цукру на натуральний цукрозамінний менша на 11,7 \%. Аналогічне зменшення активності даного ферменту спостерігається і в решті дослідних варіантах. Дана тенденція $€$ позитивною в плані збереження хімічних та органолептичних показників продукту.

Також спостерігається зниження активності пероксидази. Найменша активність даного ферменту спостерігалась у десерті гарбуз з хурмою 3 заміною цукру на натуральний цукрозамінник екстракт стевії, що становило в свіжозамороженому зразку 179,3 мк. моль розкладеного гваяколу/г сирої речовини.

Зі збільшенням терміну зберігання десертних швидкозаморожених страв активність ферментів окисно-відновної дії зростає, але дане збільшення $€$ несуттєвим і не впливає на смак та зовнішні характеристики продукту.

\section{Список використаних джерел:}

1. Птичкин, И.И. \& Птичкина, Н.М. (2012). Пищевые полисахариды: структурные уровни и функциональность. Саратов: ГУ «Типография № 6».

2. Кравчук, Н.М. \& Посна, Н.С. (2015). Розроблення технології десерту функціонального спрямування International Scientific Journal "Internauka", (3592), 36-37. Вилучено із https://www.inter-nauka.com/uploads/public/15211076711183.pdf

3. Донцова, Н.Т.\& Сивачева, А.М. (2002) Создание новых композиций быстрозамороженных готовых блюд и полуфабрикатов для повышения биологической ценности Мороженое и замороженные продукты, (3), 32-33.

4. Пиркало, В.В., Заболотна, А.В. \& Заболотний, О.І. Розширення асортименту десертних страв функціонального призначення в закладах ресторанного господарства. Матеріали VII Міжнародної науково-практичної конференції "Актуальні питання аграрної науки», присвяченої 175-річчю з дня заснування Уманського національно університету садівництва. (с. 281-283). Умань, 21 листопада 2019 р. Київ: Видавництво «Основа». 


\title{
SECTION V. MEDICINE
}

\section{COMPLICATIONS OF PREGNANCY AND LABOR OF WOMEN WITH HYPERTENSION}

\begin{abstract}
Olena Deinichenko PhD dtudent, Department of Obstetrics and Gynecology Zaporizhzhia State Medical University

Yuriy Kruty MD, Professor, Head of the Department of Obstetrics and Gynecology Zaporizhzhia State Medical University
\end{abstract}

UKRAINE

Hypertensive disorders during pregnancy are an important medical and social problem because of the wide range of pregnancy complications and adverse effects in the postnatal period. One of the most significant complications of hypertension during pregnancy is fetal growth retardation (FGR).

FGR, is a prominent among the causes of childhood morbidity and mortality. According to medical statistics, FGR complicates the course of every tenth pregnancy, causing various diseases of the fetus and child. In $70-90 \%$ of cases, fetal growth retardation is manifested in the third trimester of pregnancy in the presence of maternal diseases, pathology of the placenta and multiple pregnancy. $30 \%$ of children with hypotrophy are born prematurely.

The purpose of our study was to investigate by anamnestic and clinicalinstrumental standard methods the risk group for developing FGR in pregnant women with hypertensive disorders. A retrospective analysis of 57 case histories of pregnant patients with hypertension undergoing treatment at the Zaporizhzhya Oblast Perinatal Center in 2018-2019 was conducted. A case-control study was performed. Women were observed at 32-39 weeks of gestation. Pregnant women were divided into 2 groups. Group 1 included 29 pregnant women with chronic hypertension who were diagnosed with preeclampsia. Group 2 (comparison group) included 28 women with chronic arterial hypertension who had no pre-eclampsia. Observations of pregnant women were conducted according to current clinical protocols. Disturbances of uterine-placental circulation were established by means of the ultrasonic device "MyLabClassC-Esaote". Statistical analysis was performed using the program "STATISTICA $®$ for Windows 6.0" (Stat Soft Inc., No. AXXR712D833214FAN5). The statistical significance of the differences between the groups with the qualitative indicators was determined using Fisher's exact test, and quantitative - using the Student's T-test.

Results. There were no statistically significant differences between the groups of patients by the structure of other comorbidities, $p>0.05$. In the vast majority of patients in the main group, systolic blood pressure exceeded $140 \mathrm{mmHg}(68.6 \%)$ and diastolic exceeded $90 \mathrm{mmHg}(54.7 \%), p<0.01$. Uterine-placental circulation disorders were detected in $42.9 \%$ of patients in group 1 and $19.4 \%$ of patients in 
the comparison group, $p<0.001$. It is worth noting that in women of group $1,44.2 \%$ were diagnosed with fetal growth retardation of different degrees, whereas in group 2 patients this indicator was equal to only $26.7 \%, p<0.05$. All pregnant women were treated according to the medical standards of the Ministry of Health of Ukraine. The amount of therapy prescribed had no effect on the formation of fetal developmental delay, $p>0.05$.

Conclusions. The analysis of anamnestic and standard clinical and instrumental indicators identified the following risk factors for fetal growth retardation: combination of chronic arterial hypertension with moderate preeclampsia, excess of blood pressure over 140 and $90 \mathrm{~mm} \mathrm{Hg}$, presence of disorders of the uterine and placental circulatory system. The appointment of standard regimens for different regimens did not prevent the appearance of fetal growth retardation.

\section{References:}

1. Bramham, K., Parnell, B., Nelson-Piercy, C., Seed Paul, T, Poston, L., Chappell Lucy C. et al. (2014). Chronic hypertension and pregnancy outcomes: systematic review and meta-analysis. BMJ, 348:g2301. Doi 10.1136/bmj.g2301

2. Korol, T. M. (2013). Fetoplatsentarna nedostatnist (FPN) - aktualna problema medytsyny. Klinikoetiopatohenetychni kryterii diahnostyky, likuvannia ta profilaktyky [Fetoplacental insufficiency (FPN) - actual problem of medicine. Clinical-etiopathogenetical diagnostic criteria, tretment and prevention]. Visnyk problem biolohii i medytsyny, 1(2), 49-54. [in Ukrainian].

3. Goryunova, A. G., Simonova, M. S., Murashko, A. V. (2016). Sindrom zaderzhki rosta ploda i adaptatsiya platsentyi [Fetal growth retardation syndrome and adaptation of placenta]. Arhiv akusherstva i ginekologii im. V.F. Snegireva, 3(2), 76-80. [in Russian]. Doi 10.18821/2313-87262016-3-2-76-80

4. Trishkin, A. G., Novikova, O. N., Artymuk, N. V., Ushakova, G. A., Kiprina, E. S., Bikmetova, E. S. (2012). Gormonalno-metabolicheskie osobennosti fetoplatsentarnogo kompleksa pri zaderzhke rosta ploda [Hormonal and metabolic characteristics of fetoplacental complex in women with fetal growth restriction]. Mat i ditya $v$ Kuzbasse, spetsvyipusk 1, URL: https://cyberleninka.ru/article/n/gormonalno-metabolicheskie-osobennosti-fetoplatsentarnogokompleksa-pri-zaderzhke-rosta-ploda. [in Russian].

5. Zeisler, H., Lurba, E., Chantraine, F., Vatish, M., Cathrine, A., Sennström, M., et al. (2016). Predictive value of the sFIt-1:PIGF ratio in women with suspected preeclampsia. The New England journal of medicine, 374:13-22. Doi 10.1056/NEJMoa1414838

6. Sanghavi, M., Rutherford, J.D. (2014). Cardiovascular physiology of pregnancy. Circulation, 130(12), 1003-1008. URL: https://doi.org/10.1161/CIRCULATIONAHA.114.009029 


\section{FEATURES OF EATING DISORDERS IN YOUNG PEOPLE}

\section{Gevorgyan Sofia}

Student of 2nd medical faculty Kharkiv National Medical University

Goncharenko Valeria

Student of 2nd medical faculty Kharkiv National Medical University

SCIENTIFIC ADVISER:

Kateryna Zelenska

Ph.D., Associate Professor

Kharkiv National Medical University

UKRAINE

Relevance. Anorexia nervosa is an eating disorder in which a person intentionally restricts himself in food in order to reduce weight and / or to prevent overweight gain. Most often, this disorder occurs in adolescents and young adults. Anorexia is a dangerous disease that $h$

as gained wide popularity in recent years in European countries, where for every 100,000 people there are 4 new cases [1]. According to the researchers, this is due to a change in the criteria for evaluating female beauty and body and the popularization of fragile physique. Mortality from this disease is $5-10 \%$ [2].

Objective. To assess the propensity to develop and the clinical features of the anorexia nervosa in young people.

Materials and methods. 9 people were interviewed ( 8 women and 1 man) aged $20.2 \pm 2.1$ years. The following psychodiagnostic techniques were used: "Eating behavior assessment scale"; "Questionnaire of the image of one's own body", test "Attitude to food intake" (EAT-26). A BMI (body mass index) was also calculated by Kettle.

The results of the study. We obtained the following data: on a scale of assessing eating behavior, a desire for thinness was found in $88.2 \%$, dissatisfaction with one\&apos;s own body - 94.1\%, perfectionism - 76.5\%, distrust in interpersonal relationships - $64.7 \%$. According to the results of the "own body image questionnaire", dissatisfaction with one's own body was found in $88.2 \%$ of patients. In all patients on the EAT-26 scale, serious psychological problems were found with regard to food intake.

Conclusions. Thus, we see a clear tendency to unhealthy control of your own weight and non-compliance with the rules of good nutrition, which in the future can lead to serious health problems. The goal of controlling their own weight in most patients was a negative attitude to their own body, and the growth of the problem can be associated with distrust of close people. This should be considered when providing psychotherapeutic and psychosocial care to these patients.

\section{References:}

1. Korkina, M.V., Tsivilko, M.A. \& Marilov, V.V. (2011). Anorexia Nervosa. Moskov. Medicine. 
2. Marilov, V.V. (2010). The role of psychotherapy in the complex treatment of patients with anorexia nervosa. Moskov. Academy.

\section{THE CONTRIBUTION OF MIKHAIL IVANOVICH RAYSKY TO THE DEVELOPMENT OF GLOBAL MEDICINE}

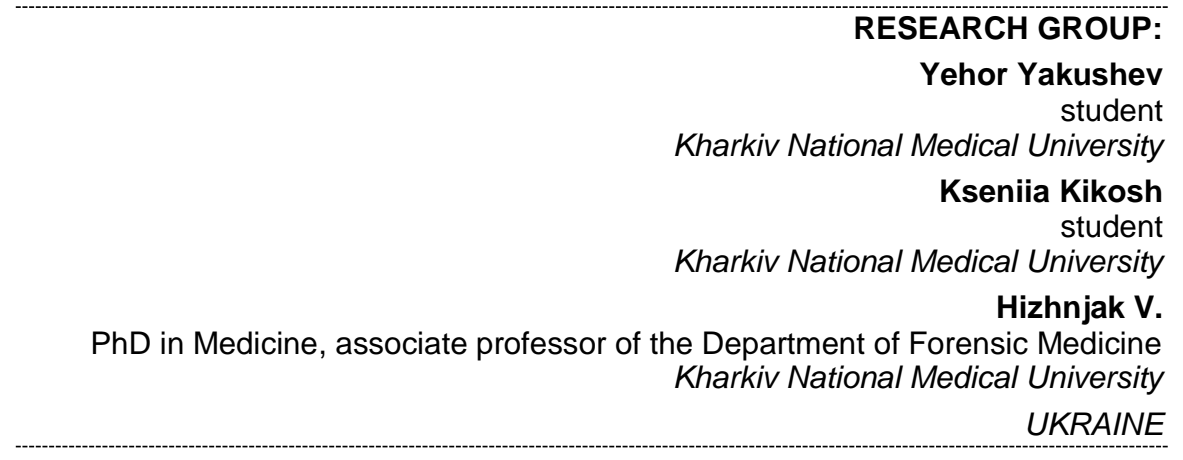

More than 60 years have passed since the death of the great forensic expert Mikhail Ivanovich Raysky, but his discoveries are still used in practical medicine. He has published more than 100 works, which include such well-known monographs as: "Immediate death due to spontaneous heart failure", "On the doctrine of recognizing death from cold", "Aconite poisoning in the Semirechensk region", "Injury in forensic medicine". The main work of M.I. Paradise is considered a textbook for students "Forensic Medicine", published under its editorship in 1953.

M. I. Paradise was born September 14 (26), 1873 in the Vaskresenski village. After graduating medical faculty of Tomsk University in 1898, he was left at the Department of Forensic Medicine under the guidance of Professor M.F. Potapov. 1904-1905 took part in the Russian-Japanese war as a junior doctor of the infantry regiment. In 1907, Mikhail Ivanovich in Tomsk defended his doctoral dissertation on the topic "To the doctrine of recognizing death from cold" received the degree of Doctor of Medicine and the title of Associate Professor. In his dissertation, Mikhail Ivanovich denied the diagnostic value of Vishnevsky's spots, but put forward a corpse pose, icy discharge from the nose and mouth, cerebral edema, overflow of the bladder, filling of the left ventricle with a healthy heart, red muscle color and mild cadaveric spots as signs of hypothermia.

Since 1912 he has been Professor at the Department of Forensic Medicine at Moscow University. In 1918, his monograph "Aconite Poisoning in the Semirechensk Region" was published, which was extremely relevant at that time, since it revealed an area where the aconite plant was used as poison by local residents. In 1920, M.I. Raisky organized and headed the first in the USSR peripheral (in the city of Saratov) forensic medical laboratory for the study of material evidence, which he led until 1926. He first combined the theory (teaching at the department) and the practice of forensic medical examination. He also introduced for the first time the teaching of the examination of living persons. M.I. Raysky was 
the organizer and active participant in many district, regional and all-union forensic medical conferences and congresses, at which he made presentations on the most pressing topics.

In 1933, he was elected a member of the plenum of the Central Research Institute of Forensic Medicine, in 1934 - a member of the Higher Attestation Commission of the NKZ RSFSR. At the same time, from 1920 to 1937, M. I. Raysky taught forensic medicine at the law faculty of the university. Mikhail Ivanovich devoted much effort to training personnel. He rightfully is the creator of a large Saratov school of forensic doctors. In 1935, M. I. Raysky was awarded the title "Honored Scientist of the RSFSR". In 1937 he was elected the head of the department of the Leningrad Medical Institute, and in 1941 - the head of the department of forensic medicine of the Naval Aviation named after S. M. Kirov. In November 1941, Mikhail Ivanovich was evacuated to Samarkand, where he remained with the academy until its re-evacuation. The Department of Forensic Medicine of the Naval Medical Academy named after S.M. Kirov M.I.Raysky headed until 1949, and in the following years he headed the Department of Forensic Medicine in Odessa and was chairman of the Leningrad and Odessa departments of VNOSMiK. At the age of 83, Mikhail Ivanovich Raysky died and was buried in the second Christian cemetery in Odessa. The successor of ideas and the student of M. I. Paradise is Svetlana Vikentievna Greenbane (1917-1995). S.V. Greenbane has written over 20 scientific papers on the problem of gunshot injuries.

Wherever M.I. Rayski had worked, he was surrounded by numerous students. 16 of his students subsequently headed the departments of forensic medicine in various universities of the country. 10 of them became doctors of medical sciences, including Yu.S. Sapozhnikov (Ivanovo, Kiev), A.M. Hamburg (Kiev), A.P. Vladimirsky (Leningrad), L. B. Leitman (Perm, Saratov), A.P. Kurdyumov (Astrakhan, Moscow), I.M. Slepyshkov (Kuibyshev, Leningrad), V.S. Pyaternev (Samarkand), A.G. Leontyev (Leningrad), L.M. Eidlin (Voronezh, Tashkent), V.F. Ogarkov (Leningrad) and others.

Research M.I. Rayski in the field of immunology was a valuable contribution not only to forensic medicine, but was also used in immunization against a number of infectious diseases. M.I. Rayski conducted a great pedagogical and advisory work. For many years he was a member of the Higher Attestation Commission and the Scientific Medical Council of the USSR Ministry of Health. His merits are highly appreciated - he was awarded the Orders of Lenin, Red Star, St. Stanislav 3 degrees (05.10.1904), St. Anna 3 degrees (05.12.1904), medal of the Honored Worker of Science. For many years he was a member of the scientific medical council of the USSR Ministry of Health.

In one of his works, Rayski claimed that: "The unity of law and medicine, science and practice is the key not only to the development of Justice and the triumph of revolutionary legality, but also the basis for the growth of science." This statement was later taken as the basis of all his works and studies.

The scientist devoted almost 25 years of his scientific activity to forensic traumatology, namely, gunshot injuries.

Nikolai Ivanovich Pirogov turned his attention to the peculiarity of the inlet bullet hole, to the presence of a tissue defect. However, most researchers of firearm injuries did not pay attention to this symptom. Mikhail Ivanovich, after reviewing this statement, delved into the study of this feature of bullet wounds, setting himself the task of finding out whether there was tissue loss and establishing its significance in 
the diagnosis. Towards the end of the research, he came to the conclusion and confirmed the presence of a tissue defect and proposed a more precise name for it as a "minus" of the tissue, in addition, he developed a methodology for studying this phenomenon in a spatial and weighted way and proved that the occurrence of a "minus" of tissue depends on the kinetic energy of the bullet. [1]

Mikhail Ivanovich paid attention to elucidating the origin of the parchment ring around the inlet bullet hole when firing at close range. This question is of great practical importance, because parchment of the skin can occur when a skin burns on fire when it is shot in clothing, or when the corpse is exposed to a flame in order to hide the traces of a crime after a gunshot wound. Parchment of burnt skin and layering of soot in such cases erase the signs of a close range of the shot. To find out, Mikhail Ivanovich started experiments. During research on his own forearm, he tested the flame of an alcohol burner for 2 seconds. To study a longer exposure to the flame (within 10 seconds), he used corpses. Based on his research experience, the author made conclusions, namely, it was found that the parchment ring around the gunshot wound is not a skin burn. To answer the question, what is the nature of skin parchmentation, Paradise began microscopic studies of the area of the inlet bullet hole. He devoted several years to research and, as a result, the author came to the conclusion that a parchment ring around the inlet holes at a close shot distance is formed as a result of the mechanical action of additional charge factors, namely soot.

M.I. Raysky especially focuses on the differentiation of soot of gunshot wounds from dirt and soot, the layering of which, resembling powder soot, can lead to diagnostic errors.

He described this phenomenon in his work: "Detection of soot on the skin during shots from a rifle at close range," where with a microscope he examined contaminated skin, covered with soot and skin with powder deposits. The author gives the main indicators for the differentiation of these ingredients [2].

In his work "Assessing the severity of bodily harm according to the draft of the new Criminal Code," Raysky suggested, evaluating the severity of injuries, take into account changes in the body that occur during the injury or in the near future, as well as the course and outcome of such injuries.

Already at that moment, in fact, a criterion for assessing life-threatening injuries was drawn up. In his works on this topic, Mikhail Ivanovich notes the complexity of such examinations, the need to study injuries in terms of the harm that they cause to this body. In the forensic examination of the severity of damage, a mechanical approach cannot take place, there should be no stamps. Therefore, Rayski attaches great importance to the work of many forensic doctors studying the effect of various injuries on the body of the victim [3].

At some point, representatives of Soviet law, most of them lawyers, came out in the press criticizing some forensic figures, including Mikhail Ivanovich Raysky. They argue that a forensic expert is not able to give an opinion on the nature of a violent death.

In his works, Mikhail Ivanovich points to the importance of forensic medical examination as a special independent type of evidence. Parsing articles of the Code of Criminal Procedure, Rayski demonstrates the work of forensic experts according to these articles without trying to "audit" them.

By criticizing the provisions of Cheltsov and Nikiforov that forensic experts can only answer "medical questions" and not "purely legal" ones, Mikhail Ivanovich 
Raysky reveals the essence of forensic medicine and draws a line between the concepts of medical and forensic data.

This article, based on an analysis of the works of Russian scientists, proves that the establishment of the kind of violent death is "a daily practice that continues the basic traditions of Soviet forensic medicine."

The position of Nikiforov and Chaltsov that forensic experts cannot give conclusions about murder and self-mutilation, M. I. Raysky regards as "a metaphysical theory based on a formal analysis of the topic," emptying the essence of its development as a science from forensic science. M. I. Raysky believes that this theory should be recognized as incorrect, almost obviously harmful.

\section{References:}

1. Rayski M.I. (1953). Sudebna medicina [Forensic Medicine].

2. Melnikov Yu. L. (1983). Bolshaya medicinska encyclopedia [Big Medical Encyclopedia].

2. Sorokina T.S. (2009). Isroria medicini (History of Medicine).

DOI 10.36074/13.12.2019.v2.09

THE EFFECT OF IMPLANTATION OF CRYOPRESERVED PLACENTAL EXPLANTS ON ADAPTATION AND COGNITIVE FUNCTIONS OF FEMALE MICE IN THE MODEL OF DYSCIRCULATORY ENCEPHALOPATHY

\footnotetext{
Irina Musatova

$\mathrm{PhD}$, Senior Researcher Institute for Problems of Cryobiology and Cryomedicine of NAS of Ukraine

Oleg Chub Neuropathologist Municipal non-profit enterprise «City Polyclinic № 19» of Kharkiv City Council

Lyudmila Tynynyka $\mathrm{PhD}$, associate professor of the Department of Fundamental General Scientific Disciplines Private Higher Educational Institution "Kharkiv International Medical University»

Andrew Nikolchenko $\mathrm{PhD}$, assistant of the Department of Fundamental General Scientific Disciplines Private Higher Educational Institution "Kharkiv International Medical University» UKRAINE

The connection of hormonal imbalance with disruption of the neurotransmitter system has significant role in the process of development of dyscirculatory encephalopathy (DE) in postmenopause (PMP). This process leads to disadaptation in the neuroendocrine system of the woman's organism, deterioration of disorders DE both impaired cognitive function and behavioral reactions [1]. The
} 
complex of therapeutic agents that are used in the treatment of DE in PMP often cause complications, so it is important to find effective and safe methods of therapy of the specified pathology.

Derivatives of the placenta is efficient at the antioxidant defense system restoration [2] in experimental neurology in the treatment of ischemic lesions of the brain [3], neurodegenerative diseases [4], for the correction of gerontological abnormalities [5]. It has been shown that morphological (reduction of neurons in the hippocampus) and cognitive impairment are corrected by oral administration of the placenta extract in ovariectomized females of rats and mice [6]. The powerful potential of regenerative action of placental derivatives may be due to the presence of various neurotrophic and growth factors: BDNF, NGF, IGF-I, HGF, EGF [7].

Cryopreserved explant of placenta (CEP) is a derivative of human placenta, therefore this one can be considered as a source of compounds and cellular elements with a naturally balanced composition both powerful neurotrophic and neuroprotective action [8].

A decrease in memory, intelligence, resistance to stress is one of the leading symptoms in the complex manifestations of DE in PMP. So there is a possibility of their correction by implantation of CEP.

Thus, the identification of the possibility corrective action of implantation of CEP on functional interhemispheric asymmetry (IA), the severity of which is determined by the adaptive capacity of the brain, and the cognitive functions of female mice in an experimental model of DE in PMP have been studied in this work.

The postmenopausal model of dyscirculatory encephalopathy has been reproduced in white BALB/c laboratory mice at 6 months of age, weight $22 \pm 1 \mathrm{~g}$ with usage bilateral ovariectomy [9] and bilateral carotid occlusion [10] according to general animal working principles. Mice have been divided into 5 experimental groups of 10 animals in a group: 1 - false females (control group), 2 - females with model PMP, 3 - females with model DE in PMP, 5 - females with model DE in PMP and $20 \mathrm{mg}$ CEP implanted in the inner hip surface. Animals have been tested in 3 weeks after surgery.

IA has been investigated using the spontaneous selection test [11]. The coefficients of interhemispheric asymmetry $(\mathrm{CIA})$ have been calculated by the formula: $\mathrm{CIA}=(\mathrm{R}-\mathrm{L}) /(\mathrm{R}+\mathrm{L}) \times 100 \%$, where $\mathrm{L}$ and $\mathrm{R}$ are the total number of left and right jogs and rotations (turns in corridors) [12]. The object position memory test, which evaluates spatial memory and the ability to detect differences in object position and shape has been used to investigating the cognitive abilities and memory of experimental animals [13]. This test is based on the spontaneous tendency of rodents to spend more time exploring a new object position than this one already known. Testing has been performed at the same day time (from 10 to 14 hours), with the limitation of external stimuli, under the same conditions. Each animal has been tested 10 times during 5 minutes.

Differences between groups have been determined according to parametric (Student's t-test) and non-parametric (Mann-Whitney test) methods of analysis. Statistical processing of the results has been performed using Past V. 3.15 software. Differences at $p<0.05$ have been considered as significant.

Studies have been shown that the greatest reduction in CIA occurred in the group of animals with DE in PMP. The CIA changed the sign to the opposite 
(inversion) in animals with DE. It is known that under the influence of extreme factors and intense adaptive processes, it is possible to reduce interhemispheric asymmetry up to the inversion of hemispheric dominance with relate to both motor and higher mental functions [14]. The movement of activity into the subdominant hemisphere is able to switch in the opposite direction in native. Thus, the inversion of IA in experimental animals in the DE model can be considered as incorporating adaptation processes due to the conservation of estrogen-producing function.

The switching activity of the hemispheres is complicated and accompanied by increased activity of the right and a decrease in the activity of the left hemisphere, that is, smoothing of IA associated with disturbance of biochemical asymmetry in the brain at pathological conditions and senescence [15]. There is a disadaptation, in which the CIA is decreased in mice with DE in PMP, that is the severity of MA, without moving activity into the subdominant hemisphere. After the injection of CEP mice with the model DE in PMP has been observed the increasing CIA to $50 \%$ of its value in mice of the control group.

Cognitive impairment is a crucial manifestation of vascular failure or DE, which determine the severity of the disease. Decrease of time investigation of animal of the position of the new object in all experimental groups, except for the group with implanted CEP has been detected at the analysis of mice cognitive functions indicators. The maximum decrease in cognitive functions has been observed in mice in the PMP and DE models (animals did not distinguish the new position of the object from the usual one). The time of investigation the new position of the object has been increased significantly (by 56\%) after the injection of CEP mice with the model DE in PMP, approaching the indicator in the control group of animals.

So, implantation of CEP to female mice in the model of DE in PMP has a positive effect on the severity of IA and cognitive functions of experimental animals, facilitating their recovery. The corrective action of CEP is possible due to the complex of placental biologically active substances with powerful regenerative potential in their composition.

\section{References:}

1. Камчатнов, П. Р. (2014). Когнитивный резерв, когнитивные нарушения и возможность их медикаментозной коррекции. Журнал неврологии и психиатрии. 114(3). 87-91.

2. Sun, T. \& Ma, Q.-H. (2013). Repairing neural injuries using human umbilical cord blood. Mol Neurobiol. 47(3). 938-945.

3. Лебединец, В. В., Овсянников, С. Е., Останков, М. В., Бондарович, Н. А., Останкова, Л. В. \& Гольцев, А. Н. (2015). Коррекция нарушений метаболизма введением криоконсервированной кордовой крови в экспериментальной модели ишемического инсульта. Научные ведомости Белгородского государственного университета. Серия: Медицина. Фармация. 31(16). 156-162.

4. Garbuzova-Davis, S., Willing, A. E., Zigova, T., Saporta, S., Justen, E. B., Lane, J. , Hudson, J. E., Chen, N., Davis, C. D. \& Sanberg, P. R. (2003). Intravenous administration of human umbilical cord blood cells in a mouse model of amyotrophic lateral sclerosis: distribution, migration, and differentiation. J Hematother Stem Cell Res. 12(3). 255-270.

5. Musatova, I. B., Volina, V. V., Chub, O. V., Prokopyuk, V. Yu. \& Prokopyuk, O. S. (2017). Effects of implantation of cryopreserved placental explants on the behavioral indices and morphological characteristics of the cerebral structures in senescent mice. Neurophysiology. 49(5). 363-371. 
6. Takuma, K., Mizoguchi, H., Funatsu, Y., Kitahara, Y., Ibi, D., Kamei, H., Matsuda, T., Koike, K., Inoue, M., Nagai, T. \& Yamada, K. (2012). Placental extract improves hippocampal neuronal loss and fear memory impairment resulting from chronic restraint stress in ovariectomized mice. $J$ Pharmacol Sci. (120). 89-97.

7. Громова, О. А., Торшин, И. Ю., Диброва, Е. А., Каримова, И. М., Гилельс, А. В. \& Кустова, Е. В. (2011). Мировой опыт применения препаратов из плаценты человека: результаты клинических и экспериментальных исследований. Обзор. Пласт хирургия и косметология. (3). $1-12$.

8. Чуб, О. В., Прокопюк, В. Ю., Прокопюк, О. С., Мусатова, І. Б. \& Шевченко, М. В. Застосування кріоконсервованих плацентарних біопрепаратів для профілактики і корекції дисфуункції ЦНС в пізньому онтогенезі (експериментальне дослідження). Проблемы старения и долголетия (том 25, приложение): Матеріали VI Національного конгресу геронтологів і геріатрів України (с. 44-45), 19-21 жовтня, 2016, Київ, Україна.

9. Rusa, R., Alkayed, N. J., Crain, B. J., Traystman, R. J., Kimes, A. S., London, E. D., Klaus, J. A. \& Hurn, P. D. (1999). 17 ß- estradiol reduces stroke injury in estrogen-deficient female animals. stroke. (30). 1665-1670.

10. Lee, J. C., Park J. H., Park O. K., Kim I. H., Yan B. C., Ahn J. H. et al. \& (2013). Neuroprotective effects of tanshinone I from Danshen extract in a mouse model of hypoxia-ischemia. Anatomy \& cell biology. 46(3). 183-190.

11. Deacon, R. M. J. \& Rawlins, N. P. (2006). T-Maze alternation in the rodent. Nature Protocols. (1). 7-12.

12. Чуян, Е. Н. \& Горная, О. И. (2009). Изменение двигательной активности животных с разным профилем моторной асимметрии в условиях гипокинезии. Физика живого. 17(2). 193-199.

13. Faizi, M., Bader, P. L., Saw, N., Nguyen, Thuy-Vi V., Beraki, S., Wyss-Coray, T., Longo, F. M. \& Shamloo, M. (2012). Thy1-hAPPLond/Swe+ mouse model of Alzheimer's disease displays broad behavioral deficits in sensorimotor, cognitive and social function. Brain Behav. 2(2). 142-154.

14. Фокин, В. Ф. \& Пономарева, Н. В. (2004). Динамические характеристики функциональной межполушарной асимметрии. В кн.: Функциональная межполушарная асимметрия. Хрестоматия. Н. Н. Боголепов \& В. Ф. Фокин (ред.). Москва: Научный мир.

15. Клименко Л. Л. (2004). Структурно-функциональная организация межполушарной асимметрии: экспериментальные и клинические аспекты проблемы $B$ кн.: Функциональная межполушарная асимметрия. Хрестоматия. Н. Н. Боголепов \& В. Ф. Фокин (ред.). Москва: Научный мир. 


\section{ВПЛИВ ОЛІЇ АМАРАНТУ НА ЗМІНИ СТРУКТУРНО- МЕТАБОЛІЧНОГО КОНТИНУУМА У ЩУРІВ $3 \mathrm{CCL}_{4}$ ОБУМОВЛЕНОЮ ІНТОКСИКАЦІЄЮ}

Татаріна Ольга Володимирівна

канд. мед. наук, доцент, доцент кафедри ортопедичної стоматології Вінницький національний медичний університет ім. М. І. Пирогова

УКРАÏHA

Особливості сучасного розвитку суспільства обумовлює збільшення ксенобіотичного навантаження на людину і тварин. [1-3]

Ксенобіотики (чужорідні речовини) - з'єднання які поступають в організм 3 оточуючого середовища i не використовуються організмом для життєдіяльності, або у якості джерела енергії. Найбільш поширені дві групи ксенобіотиків:

1) продукти промисловості, сільського господарства, транспорту;

2) речовини які використовуються в побутовій хімії, миючих засобах, засобах дератизації, інсектицидах.

Для попередження неблагополучної дії цих з'єднань в ході еволюції сформувались механізми їх детоксикації і виведення з організму [4-6].

Основним органом, в якому здійснюється елімінація ксенобіотиків являється печінка, багаточисленні фрерментні системи, які здійснюють модифікацію цих з'єднань. Послідуюче виведення продуктів елімінації ксенобіотиків здійснюється нирками [4-6].

Довготривале ксенобіотичне навантаження викликає порушення функції цих органів, яке в літературі визначається як псевдогепаторенальний синдром $[6,7]$.

Розвиток такої патології пов'язують з наявністю гіпернефроми, серцевої недостатності, ревматичних хвороб, діями хімічних отрут таких як, тетрахлорид вуглецю, сульфат міді, свинець $[6,7]$.

Основним принципом боротьби з псевдогепаторенальним синдромом заходи спрямовані на відновлення функції печінки і нирок. Оптимальним шляхом відновлення цих органів $€$ замісна терапія, яка забезпечує надходження в організм необхідних амінокислот і фосфоліпідів. Ефективність дії фармацевтичних препаратів, до складу яких містять рафіновані з'єднання, нижче ніж у природних аналогів [8-11].

Тому, в останній час дослідники звертають увагу на природні продукти, в яких містяться необхідні амінокислоти і фосфоліпіди, зокрема продукти амаранту (масло) [12,13].

Мета роботи - здійснити оцінку впливу олії амаранту на структурнометаболічний континуум у щурів 3 несмертельною $\mathrm{CCL}_{4}$-обумовленою інтоксикацією.

Матеріали і методи досліджень.

Матеріалом дослідження слугували результати, які були отримані під час дослідження 76 білих щурів-самців лінії Вістар аутобредного розведення 
масою 180-200 гр., яких утримували на повноцінному раціоні віварію з вільним доступом до їжі та води при температурі $19-21^{\circ} \mathrm{C}$.

Експерименти на тваринах були проведені з дотриманням вимог положень Директиви 2010/63/EU Європейського парламенту і Ради від 22 вересня 2010 р. По захисту тварин, які використовуються з науковою метою [14] та Наказу Міністерства Освіти і Науки, Молоді та Спорту України №249 від 01.03.2012р. [15].

У відповідності з завданням роботи тварини були ранжовані на 3 групи:

I група - 16 тварин, які утримувались в умовах віварію і не підлягала ніяким взаємодіям, дані отримані при їх дослідженні слугували контролем;

II група - 30 тварин, у яких створювали несмертельне токсичне навантаження шляхом поодинокого введення 0.5 мл тетрахлориду вуглецю;

III група - 30 тварин, які на фоні несмертельного токсичного навантаження, отримували 0.3 мл амарантової олії, яка вводилась внутрішньошлунково.

Тривалість експерименту 7 діб. По завершенню експерименту тварин виводили із досліду. У них забирали шматочки печінки та нирок ля проведення морфологічних досліджень і 5 мл крові для проведення біохімічних досліджень.

Матеріал відібраний для морфологічних поділили на дві частини. Одну частину фріксували на 4\% параформальдегідом, проводили через спирти зростаючої інтоксикації і заливали в целоїдин по загальноприйнятій методиці.

3 отриманих блоків виготовляли мікротонкі зрізи товщиною 7 мкм, які зафрарбовували гематоксилін - еозином. Отримані препарати досліджували за допомогою світлового мікроскопа. Матеріал для гістоензиматичних досліджень заморожених сухою вуглекислотою $\left(t^{\circ}=-44^{\circ} \mathrm{C}\right)$, з отриманих блоків виготовляли кріостатні середовища - II мкм на яких по прописам Лойди визначали активність СДГ, ПДГ, ГДГ в тканинах печінки і нирок.

Результати цитохімічних досліджень оцінювали напівкількісним методами. Кров використовували для визначення біохімічним методом наступних показників: активність АЛТ, АСТ; Білірубін та його фракції; тимолова проба; вміст сечовини і креатиніну в крові та сечі; вміст загального білка; вміст МДА; активність каталази і $\mathrm{Na} / \mathrm{K} \mathrm{i} \mathrm{Ca/Mg} \mathrm{-} \mathrm{АТФ-аз.}$

За добу до виведення тварин з досліду у них збирали добову сечу i оцінювали об'єм добового діурезу; швидкість клубочкової фрільтрації; \%\% канальцевої реабсорбції; вміст і виведення хлорид іонів в сечі. Отримані дані піддали стандартній статистичній обробці з використанням коефіцієнта Стьюдента, результати зводили в таблиці.

Результати та їх обговорення.

Проведені морфологічні дослідження показали, що 7 діб несмертельної інтоксикації тетрахлорид вуглецем супроводжуються деструктивними змінами в печінці, що проявляється стоншенням і навіть зникненням міжчасточкових перетинок, явищами плазмостазу в судинах, невпорядкованістю розміщення гепатоцитів в часточках, вакуолізацією цитоплазми частини з них, зменшенням їх розмірів, пікнозом ядер, комковатістю цитоплазми.

За даними гістоензимологічних досліджень активність досліджених ферментів складає: активність СДГ коливалась від 3.0 до 4.5 ум. од. опт. щільності; активність ЛДГ 5.0 ум. од. опт. щільності; активність ГДГ дещо збільшувалась і коливалась від 5.0 до 6.5 ум. од. опт. щільності. 
В той же час, в нирках, також спостерігались прояви дегенеративних змін. Це проявлялось в наявності лапчастих капілярних клубочків в ниркових канальцях. В цитоплазмі деяких ендотеліоцитів спостерігались вакуолі. В деяких ниркових канальцях в боуменовому просторі містились гомогенні еозинофільні маси. В частині канальців має місце значне набрякання епітелію, аж до закриття просвіту канальця. В частині канальців просвіт зайнятий злущеними епітеліоцитами з пікнотичними ядрами.

Зміни активності досліджених дегідрогеназ. Активність СДГ в епітелії канальців складає $6.5 \pm 0.5$ ум. од.; активність ЛДГ $6.5 \pm 0.44$ ум. од.; активність ГДГ $5.5 \pm 0.5$ ум. од. Остання дещо підсилена, а в цілому активність досліджених ферментів близька до даних контролю, тобто енергозабезпечення процесів життєдіяльності нирок зберігається на достатньому рівні.

Введення амарантового масла щурам 3 тетрахлорвуглецевою інтоксикацією здійснювало позитивний вплив на структурні характеристики печінки та нирок. В печінці це виражалось в чіткому розмежуванні часток печінки, помірному кровонаповненню тріад; упорядкованому розташуванні гепатоцитів в балках; появі двоядерних гепатоцитів; різкому зменшенні гепатоцитів які містять вакуолі в цитоплазмі, при цьому вакуолі мілкі і поодинокі.

Особливістю печінки щурів цієї групи було потовщення стінки центральної вени в ряді часток і появою між дольками скупчення неупорядковано розташованих гепатоцитів зі середньо зафарбованим ядром і комковатою цитоплазмою.

Відповідно даними гістоензимологічних досліджень, активність СДГ гепатоцитів в різних частинах часточок і різних дольках коливається від 5.0 до 7.0 ум. од. опт. щільності. Активність ЛДГ в усіх гепатоцитах однакова і складає $5.6 \pm 0.2$ ум. од. опт. щільності.

Активність ГДГ також однакова в гепатоцитах різних утворень паренхіми, близька до норми і складає $4.5 \pm 0.19$ ум. од. опт. щільності.

Мікроскопічне дослідження нирок також виявило позитивні тенденції в їх структурних характеристиках. Це виражалось в рівномірному розприділенні ниркових тілець і наявності в більшості округлих капілярних тілець. В незначної кількості ниркових тілець, капілярні клубочки яких лапчасті, між капілярними петлями визначаються тонкі прошарки сполучної тканини. Більшість канальців звичайної структури. Зустрічаються одиночні скупчення епітеліоцитів 3 пікнотичними ядрами, між ними розміщені пучки ніжних фібринозних волокон. Інтерстиційний прошарок звичного вигляду.

По даним гістоензимологічних досліджень активність ферментів має схильність до послаблення. В епітеліоцитах активність СДГ $6.6 \pm 0.09$ ум. од., в ендотеліоцитах $3.0 \pm 0.05$ ум. од. Активність ЛДГ $5.5 \pm 0.5$ та $3.0 \pm 0.07$ відповідно. Активність ГДГ в епітелії канальців $3.5 \pm 0.05$ ум. од., а в ендотеліоцитах $4.0 \pm 0.07$ ум. од.

3 вищевказаного слідує, що застосування олії амаранту пом'якшує прояви дегенеративних процесів в нирках і печінці, а в останній посилює прояви репарації.

Позитивний вплив олії амаранту відмічається і по відношенню до метаболічних процесів в організмі піддослідних тварин. 
Згідно отриманих даних (табл. 1) розвиток тетрахлорид вуглецевої інтоксикації супроводжується активацією АлАТ і АсАТ в плазмі, що може свідчити про деградацію клітинних мембран гепатоцитів, то застосування амарантової олії забезпечує зниження активності цих ферментів нижче значень контролю.

Таблиця 1

Порівняльна оцінка показників метаболізму обміну речовину щурів при навантаженні тетрахлоридом вуглецю $\left(\mathrm{CCl}_{4}\right)$ та її корегуванні маслом амаранту

\begin{tabular}{|c|c|c|c|c|}
\hline & $\begin{array}{l}\text { ГРУПИ } \\
\text { ПОКАЗНИКИ }\end{array}$ & КОНТРОЛЬ & $\begin{array}{c}7 \text { доба } \\
\text { навантаження } \\
\mathrm{CCl}_{4} \\
\end{array}$ & $\begin{array}{c}7 \text { доба } \\
\text { навантаження } \mathrm{CCl}_{4} \\
+ \text { масло амаранта }\end{array}$ \\
\hline Ал АТ & моль/л) & $113.31 \pm 2.13$ & $\begin{array}{c}194.7 \pm 17.3 \\
P<0.05\end{array}$ & $\begin{array}{l}78.6 \pm 3.7 \\
P<0.001\end{array}$ \\
\hline Ac AT & моль/л) & $289.64 \pm 12.12$ & $\begin{array}{c}316.82 \pm 15.7 \\
P<0.05\end{array}$ & $\begin{array}{c}230.84 \pm 12.1 \\
P>0.05\end{array}$ \\
\hline БІЛІРУ & Загальний & $84.4 \pm 0.28$ & $\begin{array}{c}5.02 \pm 0.27 \\
P<0.01\end{array}$ & $\begin{array}{l}4.7 \pm 0.39 \\
P<0.001\end{array}$ \\
\hline $\begin{array}{c}\text { БІН } \\
\text { (мкмол }\end{array}$ & Прямий & $3.06 \pm 0.18$ & $\begin{array}{l}1.71 \pm 0.2 \\
P<0.001\end{array}$ & $\begin{array}{c}1.86 \pm 0.1 \\
P<0.01\end{array}$ \\
\hline b/л) & Непрямий & $5.38 \pm 0.15$ & $\begin{array}{c}3.31 \pm 0.12 \\
P<0.01\end{array}$ & $\begin{array}{c}3.01 \pm 0.2 \\
P<0.05\end{array}$ \\
\hline Сечови & (ммоль/л) & $2.08 \pm 0.27$ & $\begin{array}{l}5.3 \pm 0.3 \\
P<0.01\end{array}$ & $\begin{array}{c}3.89 \pm 0.17 \\
P<0.01\end{array}$ \\
\hline Креатин & н (ммоль/л) & $47.8 \pm 0.63$ & $\begin{array}{c}72.2 \pm 3.8 \\
P<0.01\end{array}$ & $\begin{array}{c}46.3 \pm 6.3 \\
P<0.5\end{array}$ \\
\hline Загальң & й білок (мг/мл) & $68.7 \pm 2.74$ & $\begin{array}{c}79.25 \pm 8.3 \\
P<0.02\end{array}$ & $\begin{array}{c}59.0 \pm 4.0 \\
P<0.5\end{array}$ \\
\hline Тимоло & а проба (од. SH) & до 1.0 & $\begin{array}{c}0.94 \pm 0.08 \\
P>0.05\end{array}$ & $\begin{array}{c}0.98 \pm 0.03 \\
P>0.05\end{array}$ \\
\hline МДА & & $6.51 \pm 0.22$ & $\begin{array}{c}8.21 \pm 0.33 \\
P<0.01\end{array}$ & $\begin{array}{c}7.11 \pm 0.31 \\
P<0.5\end{array}$ \\
\hline Каталаз & & $62.22 \pm 2.17$ & $\begin{array}{c}47.57 \pm 2.13 \\
P<0.01\end{array}$ & $\begin{array}{c}57.34 \pm 2.25 \\
P<0.5\end{array}$ \\
\hline $\mathrm{NO}_{x}$ & & $37.9 \pm 1.6$ & $\begin{array}{c}46.53 \pm 1.3 \\
P<0.02\end{array}$ & $\begin{array}{c}47.53 \pm 1.7 \\
P<0.02\end{array}$ \\
\hline Сечова & ислота & $265.6 \pm 15.4$ & $\begin{array}{c}186.34 \pm 3.8 \\
P<0.01\end{array}$ & $\begin{array}{c}169.1 \pm 7.9 \\
P<0.02\end{array}$ \\
\hline $\mathrm{Na}^{+} / \mathrm{Ka}^{+}$ & АТФ-аза & $6.40 \pm 0.62$ & $\begin{array}{c}4.52 \pm 0.19 \\
P<0.01\end{array}$ & $\begin{array}{c}7.23 \pm 0.71 \\
P<0.5\end{array}$ \\
\hline $\mathrm{Ca}^{+2} / \mathrm{Mg}$ & - АТФ-аза & $9.11 \pm 0.93$ & $\begin{array}{c}6.69 \pm 0.49 \\
P<0.05\end{array}$ & $\begin{array}{c}7.94 \pm 0.71 \\
P<0.5\end{array}$ \\
\hline
\end{tabular}

[авторська розробка]

Кількість білірубіну і його фрракцій у тварин обох груп нижче даних контролю, це дозволяє припустити, що має місце компенсаторне посилення жовчовиділення. В той же час, якщо при ізольованій інтоксикації загальний білок в плазмі зростає, що свідчить про активацію білкового синтезу, а оскільки при цьому знижується тимолова проба, можна припустити, що більше утворюється альбумінів, необхідних для зв'язування і транспортування ксенобіотиків. При застосуванні амарантової олії вміст загального білка знижується, що може свідчити про пригнічення білкового синтезу (зниження функціонального навантаження на печінку), а оскільки тимолова проба при цьому залишається близькою до контролю, можна припускати, що потреби в 
додатковій кількості альбумінів немає. Можливо це пов'язано з позаклітинною елімінацією ксенобіотика олією амаранту. Що стосується вмісту сечовини і креатину, то при застосуванні олії амаранту перший показник зростає, але в 1.4 рази менший ніж при ізольованій $\mathrm{CCL}_{4}$ - інтоксикації, а вміст креатиніну взагалі зберігається на рівні контролю. Можливо збереженість мембран клітин при застосуванні олії амаранту знижує інтенсивність катаболічних процесів азотистих з'єднань в усьому організмі тварини.

Що стосується системи ПОЛ/АОЗ, то відповідно до отриманих даних (табл. 1) при самостійній $\mathrm{CCL}_{4}$ - інтоксикації має місце підсилення активності ПОЛ і зниження активності каталази, результатом таких змін були умови для посиленого пошкодження клітинних мембран. При використанні олії амаранту показники стану системи ПОЛ/АОЗ залишаються близькими до даних контролю. Це дозволяє припускати, що під впливом олії амаранту деградація клітинних мембран гальмується, або не відбувається.

Також змінюється при розвитку $\mathrm{CCL}_{4}$ - інтоксикації і активність ферментів системи АТФ-аз. Згідно даних (табл. 1) активність $\mathrm{Na}^{+} / \mathrm{Ka}^{+}$і $\mathrm{Ca}^{+2} / \mathrm{Mg}^{+2} \mathrm{ATФ-аз}$ знижується при ізольованій $\mathrm{CCL}_{4}$-інтоксикації, крім того змінюеться співвідношення активності цих ферментів, що можна розглядати як умови порушення трансмембранного транспорту - важливого елементу життєдіяльності клітин. При застосуванні олії амаранту активність цих ферментів залишається близькою до даних контролю, хоча співвідношення їх активності змінюється. Це дозволяє припускати, що у випадку застосування олії амаранту енергозабезпечення трансмембранного транспорту ближче до оптимального, що створює умови для кращого протікання процесів регенерації.

На фоні структурних змін в нирках спостерігаються порушення їх функції.

Таблиця 2

Вплив амарантового масла на показники функції нирок у щурів ${ }_{3} \mathrm{CCl}_{4}$-обумовленою інтоксикацією

\begin{tabular}{|c|c|c|c|}
\hline $\begin{array}{l}\text { ГРУПИ } \\
\text { ПОКАЗНИКИ }\end{array}$ & КОНТРОЛЬ & $\begin{array}{c}7 \text { доба } \\
\text { навантаження } \\
\mathrm{CCl}_{4}\end{array}$ & $\begin{array}{c}7 \text { доба навантаження } \\
\mathrm{CCl}_{4}+\text { масло } \\
\text { амаранта }\end{array}$ \\
\hline 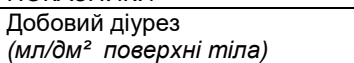 & $0.96 \pm 0.006$ & $\begin{array}{c}1.75 \pm 0.09 \\
P<0.01\end{array}$ & $\begin{array}{c}0.86 \pm 0.006 \\
P<0.01\end{array}$ \\
\hline 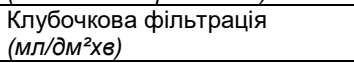 & $0.16 \pm 0.009$ & $\begin{array}{l}0.13 \pm 0.002 \\
P>0.05\end{array}$ & $\begin{array}{c}0.19 \pm 0.001 \\
P<0.01\end{array}$ \\
\hline $\begin{array}{l}\text { Канальцієва реабсорбція } \\
\text { (\% від фільтрації) }\end{array}$ & $99.58 \pm 0.09$ & $\begin{array}{c}99.19 \pm 0.003 \\
P<0.01\end{array}$ & $\begin{array}{c}99.27 \pm 0.005 \\
P<0.01\end{array}$ \\
\hline $\begin{array}{l}\text { Виведення креатиніну } \\
\text { (ммоль) }\end{array}$ & $0.017 \pm 0.001$ & $\begin{array}{c}0.015 \pm 0.001 \\
P<0.01\end{array}$ & $\begin{array}{c}0.20 \pm 0.001 \\
P<0.01\end{array}$ \\
\hline $\begin{array}{l}\text { Виведення сичовини } \\
\text { (ммоль) }\end{array}$ & $0.80 \pm 0.05$ & $\begin{array}{l}0.76 \pm 0.004 \\
P>0.05\end{array}$ & $\begin{array}{l}0.92 \pm 0.01 \\
P<0.05\end{array}$ \\
\hline Виведення хлоридів (ммоль) & $1.24 \pm 0.05$ & $\begin{array}{l}1.80 \pm 0.01 \\
P<0.01\end{array}$ & $\begin{array}{l}1.87 \pm 0.01 \\
P<0.01\end{array}$ \\
\hline рН добової сечі (од. pH) & $8.75 \pm 0.54$ & $\begin{array}{c}8.37 \pm 0.04 \\
P>0.5\end{array}$ & $\begin{array}{c}7.94 \pm 0.03 \\
P<0.05\end{array}$ \\
\hline
\end{tabular}

[авторська розробка]

Відповідно до отриманих даних (табл. 2) у щурів III-ої групи (які отримували олію амаранта) об'єм добового діурезу нижче, ніж в контролі (група I), але вище ніж у тварин які її не приймали (група II). Це пов'язано із значним 
зростанням швидкості клубочкової фрільтрації. Підвищення швидкості клубочкової фрільтрації можливо пов'язано із змінами білкового складу крові і посиленою позаклітинною елімінацією $\mathrm{CCL}_{4}$ компонентами олії амаранту. При цьому відсоток канальцевої реабсорбції залишається зниженим у порівнянні 3 контролем.

Підвищення клубочкової фрільтрації сприяє виведенню токсичних метаболітів, про що свідчить підвищення кількості сечовини яка виводиться і нормалізація виведення креатиніну.

Посилене виведення токсичних метаболітів сприяє зниженню ксенобіотичного навантаження, що створює умови для посиленої регенерації пошкоджень пов'язаних з дією $\mathrm{CCL}_{4}$

Також, вище норми залишається швидкість виведення хлоридів, хоча вона близька до даних тварин 3 неконтрольованою $\mathrm{CCL}_{4}$-обумовленою інтоксикацією (група II). Вочевидь, олія амаранту не корегує зміни іонообмінної функції нирок. На фоні цих змін спостерігається незначне закислення сечі за рахунок зміненого іонного обміну.

\section{Висновки.}

Таким чином результати досліджень показали, що $\mathrm{CCL}_{4}$-обумовлена інтоксикація супроводжується дегенеративними змінами структури печінки та нирок. При цьому відбуваються зміни фрункції цих органів характерні для псевдогепаторенального синдрому.

У випадку отримання щурами $3 \mathrm{CCL}_{4}$-обумовленою інтоксикацією олії амаранту в нирках різко слабшають прояви дистрофрічно-дегенеративних процесів, а в печінці ще й підсилюються репаративні процеси. Функції цих органів повністю не нормалізуються але суттєво покращуються.

\section{Список використаних джерел:}

1. Куліцька, М. І. (2015) Функціональний стан печінки у щурів за умов експериментального гепаторенального синдрому. Медична та клінічна хімія. (65). 74-77. https://doi.org/10.11603/mcch.2410-681X.2015.v17.i4.5726

2. Савченко, В. М., Ніколенко, Є. Я., Сокруто, О. В., Вовк, К. В. (2009). Гепаторенальний синдром в практиці сімейного лікаря (критерії діагнозу та лікування). Вісник Харківського національного університету імені В. Н. Каразіна, (17), 63-72. Вилучено з: http://dspace.univer.kharkov.ua/handle/ 123456789/4096

3. Куліцька М. І., Миронюк Д. Б., Криницька І. Я., Яремчук О. 3. (2015) Патогенетичні аспекти гепаторенального синдрому (огляд літератури). Медична та клінічна хімія, (62), 114-120. Вилучено з: http://nbuv.gov.ua/UJRN/Medkh_2015_17_1_27

4. Wadei, H. M., Mai, M. L., Ahsan, N., Gonwa, T. A. (2006) Hepatorenal Syndrome: Pathophysiology and Management. Clinical Journal of the American Society of Nephrology, (1), 1066-1079. https://doi.org/10.2215/CJN.01340406

5. Белявський, В.В., Роговий, Ю.Є. (2010) Патогенез гепаторенального синдрому. Буковинський медичний вісник, (55), 119-122. Вилучено 3: https:/l www.bsmu.edu.ua/files/BMV/BMV-2010-14-03(55)/BMV-2010-14-03(55)-119.pdf

6. Angeli, P., Morando, F. (2010) Optimal management of hepatorenal syndrome in patients with cirrhosis. Hepatic Medicine: Evidence and Research. (2), 87-98. https://doi.org/10.2147/HMER.S6918

7. Halit Ziya Dundar, Tuncay YIImazlar (2015) Management of hepatorenal syndrome. World Journal of Nephrology, 4(2), 277-286 https://dx.doi.org/10.5527/wjn.v4.i2.277 
8. Mallikarjun S, Rao A, Rajesh G, Shenoy R, Pai M. (2016) Antimicrobial efficacy of Tulsi leaf (Ocimum sanctum) extract on periodontal pathogens: An in vitro study. Journal of Indian Society of Periodontology, (20). 145-150. Вилучено 3: https://www.ncbi.nlm.nih.gov/pubmed/27143825

9. Минушкин, О.Н. (2016) Гепатопротекторы в лечении некоторых заболеваний печени. Медицинский Совет, (14), 52-57. https://doi.org/10.21518/2079-701X-2016-14-52-57

10. Звягінцева, Т. Д., Чернобай, А. І. (2014) Хронічні захворювання печінки: фокус на полікомпозиційні рослинні гепатопротектори-антиоксиданти. Сучасна Гастроентерологія, № 4, (78). 70-76. Вилучено з: http://nbuv.gov.ua/UJRN/SGastro_2014_4_12

11. Зверков, И.В., Минушкин, О.Н. (2018) Сравнительная характеристика эфффективности препаратов эссенциальных фосфолипидов и урсодезоксихолевой кислоты в терапии хронических заболеваний печени. РМЖ. Медицинское обозрение, №7(I), 33-36 Вилучено з: https://www.rmj.ru/archive/gastroenterologiya-mo-7-1-2018/

12. Martın S., Adriana Scilingo, Maria Cristina (2019) Effect of the Incorporation of Amaranth (Amaranthus Mantegazzianus) into Fat- and Cholesterol-Rich Diets for Wistar Rats. Journal of Food Science, (84), № 11, 3075-3082. https://doi.org/10.1111/1750-3841.14810

13. Sabbione A.C., Ogutu F.O., Scilingo A. (2019) Antiproliterative Effect of Amaranth Proteins and Peptides on HT-29 Human Colon Tumor Cell Line. Plant Foods for Human Nutrition, (74), №l, 107-114. https://doi.org/10.1007/s11130-018-0708-8

14. Директива 2010/63 / ЄС Європейського Парламенту та Ради від 22 вересня 2010 року про захист тварин, які використовуються в наукових цілях. Official Journal of the European Union (276), 0033 - 0079. Вилучено 3: http://data.europa.eu/eli/dir/2010/63/oj

15. Про затвердження Порядку проведення науковими установами дослідів, експериментів на тваринах. Наказ Міністерства Освіти і Науки, Молоді та Спорту України № 249 від 01.03.2012 p. Вилучено 3: https://zakon.rada.gov.ua/laws/main/z0416-12

\title{
ОСОБЛИВОСТІ ПАТОГЕНЕЗУ ГЕСТАЦІЙНОГО ЦУКРОВОГО ДІАБЕТУ
}

\begin{abstract}
Шарун Сабіна Нурадінівна
студентка медичного фракультету

Харківський національний медичний університет

Лісова Єлизавета Миколаївна

студентка медичного факультету

Харківський національний медичний університет

НАУКОВИЙ КЕРІВНИК:

Сулхдост Інна Олександрівна

канд. мед. наук, асистент кафедри патологічної фізіології імені Д.О. Альперна

Харківський національний медичний університет

УКРАÏHA

Актуальність. Гестаційний цукровий діабет - це захворювання, яке несе в собі низку ризиків перинатальної захворюваності і смертності, можливість розвитку цукрового діабету 2-го типу у матері і маніфестації розладів в період розвитку дитини. За даними ряду досліджень близько $75-90 \%$ випадків
\end{abstract}


високого рівня глюкози плазми крові під час вагітності $є$ наслідком даної патології. У тезах розглянуті патогенетичні основи розвитку цукрового діабету під час вагітності.

Виклад матеріалу. Висока частота даної патології пов'язана з тим фрактом, що фізіологічна вагітність супроводжується такими особливостями вуглеводного обміну, які багато в чому нагадують модель цукрового діабету. Зокрема, фізіологічна вагітність характеризується двома головними змінами в гомеостазі глюкози. Перша - це безперервне транспортування глюкози до плоду і плаценти. Трансплацентарний транспорт глюкози здійснюється транспортерами глюкози (ГЛЮТ), головним чином ГЛЮТ1 і ГЛЮТЗ. В даний період рівень глюкози в організмі знижується швидше, ніж у невагітних жінок, в той час як ліполіз і кетогенез активізуються. Друга - це відмічене 3 ІІ триместру вагітності зниження чутливості тканин до інсуліну, або інсулінорезистентність.

При фрізіологічній вагітності в організмі жінки відбуваються істотні гормонально-біологічні зміни, пов'язані з формуванням нового ендокринного органу - плаценти, секретуючого в материнський кровотік білкові і стероїдні гормони: хоріонічний гонадотропін (ХГ), плацентарний лактоген (ПЛ), естрогени, прогестерон, кортикостероїди, концентрація яких в крові також зростає зі збільшенням термінів вагітності. Ці гормони мають контрінсулярний ефект - знижують чутливість периферичних тканин до ендогенного інсуліну. При цьому збільшується компенсаторна гіперактивність бета-клітин, гіперінсулінемія, в той час як в плаценті відбувається посилений розпад інсуліну. Цей процес компенсується підвищенням продукції і зниженням кліренсу ендогенного інсуліну матері. Інсулінорезистентність посилюється збільшенням калорійності прийнятої матір'ю їжі, зниженням фрізичної активності, і збільшенням ваги. При наявності ендогенних факторів, таких як спадкова схильність до ЦД 2 типу, ожиріння, секреція інсуліну стає недостатньою для подолання інсулінорезистентності, що і призводить до появи гіперглікемії. Гіперглікемія у матері призводить до розвитку діабетичної фетопатії: велика маса тіла, широкий плечовий пояс, надмірний розвиток підшкірно-жирової клітковини, кругле, місяцеподібне обличчя, набряклість шкіри, гіпертрихоз. Ризик розвитку вроджених вад розвитку і самовільних абортів при ГЦД такий же, як в загальн ій популяції i не пов'язаний 3 декомпенсацією ЦД, так як часто ГЦД розвивається після завершення органогенезу в плода.

Декомпенсація ГЦД може стати причиною перинатальної смертності. При ГЦД частіше розвивається прееклампсія і еклампсія, що нерідко вимагає екстреного розродження шляхом операції кесаревого розтину

Однією з особливостей цього захворювання $є$ труднощі діагностики. ГЦД часто залишається нерозпізнаним тому, що клінічні прояви його або відсутні, або неспецифічні. Крім того, в нашій країні єдині підходи до діагностики цієї патології відсутні. Водночас правильна організація скринінгового обстеження вагітних є надзвичайно важливою. За сучасними рекомендаціями, діагностика повинна будуватися на виділенні факторів ризику розвитку ГЦД з подальшим застосуванням тестів з навантаженням глюкозою в групах середнього та 
високого ризику. Діагностична тактика визначається при першому візиті до лікаря на підставі визначення ризику ГЦД.

Дослідження глюкози сечі - досить інформативний показник, так як поріг виведення глюкози у вагітних навіть в нормі суттєво знижений (в середньому до 8,5-5,5 ммоль/л). Глюкозурія спостерігається у 10\% жінок. Ії̈ пов'язують 3 відставанням швидкості реабсорбції глюкози в нирках від швидкості фрільтрації. Також можливо, що це спосіб захисту плода від можливої гіперглікемії на тлі наявної інсулінорезистентності. Проте, є дані, що глюкозурія супроводжується великою кількістю ускладнень вагітності (наприклад, частота переривання вагітності досягає $25 \%$, а макросомія плода виявляється в 5 разів частіше, ніж в популяції). Тому у всіх випадках необхідно виявляти причини глюкозурії. Дослідження глюкози крові зазвичай полягає у визначенні глюкози цільної капілярної крові. Однак, можливо дослідження венозної крові, а також плазми. У зв'язку з різноманітністю методик, в кожному випадку повинна вказуватися норма для даного виду дослідження. Тест слід проводити 2 рази в один день - натще і через 2 години після обіду (або щільного сніданку). Тільки при такому підході діагностична цінність дослідження максимальна. Для вагітних нормою вважається, якщо натщесерце рівень глюкози цільної капілярної крові коливається в межах 3,5-5,3 ммоль/л, а через 2 години після їжі - не вище 7,8 ммоль/л. Якщо змін в аналізах крові та сечі не виявляється, навантажувальні тести не проводяться.

Висновки. 3 огляду на неухильне збільшення поширеності гестаційного цукрового діабету в сучасному суспільстві, а також високу ймовірність виникнення ускладненого перебігу вагітності та пологів у пацієнток з даним видом патології, стає очевидною необхідність кваліфікованого планування і ведення вагітності на тлі порушення вуглеводного обміну. Гостро стоїть питання про необхідність вироблення єдиного алгоритму діагностики та лікування ГЦД. Очевидна необхідність профілактичних програм в профільних установах і скринінгових дослідженнях, відповідно до сучасних стандартів.

\section{Список використаних джерел:}

1. Жорова В. Е. \& Манасова 3. Ш. (2015). Гестационный сахарный диабет: патогенез, особенности диагностики и лечения // Здоровье и образование в XXI веке, (4). Вилучено 3 $\mathrm{https://cyberleninka.ru/article/n/gestatsionnyy-saharnyy-diabet-patogenez-osobennosti-}$ diagnostiki-i-lecheniya.

2. Камилова М. Я., Малахова М-м. А., Зарифова П. Г. \& Файзова М. Ф. (2008). Особенности течения беременности и родов у женщин с гестационным диабетом и раннего неонатального периода у их новорожденных. ДАН РТ, (11). Вилучено 3 https://cyberleninka.ru/article/n/osobennosti-techeniya-beremennosti-i-rodov-u-zhenschin-sgestatsionnym-diabetom-i-rannego-neonatalnogo-perioda-u-ih-novorozhdennyh. 


\section{ПРОБЛЕМА ЛІКУВАННЯ МУЛЬТИРЕЗИСТЕНТНОГО ТУБЕРКУЛЬОЗУ У ВАГІТНИХ}

НАУКОВО-ДОСЛІДНА ГРУПА:

Полякова В.В.

здобувач вищої освіти медичного факультету Харківський національний медичний університет

Лєсна А.C.

здобувач вищої освіти медичного факультету Харківський національний медичний університет

Бутов Д.О. д-р. мед. наук, проф. кафедри фртизіатрії та пульмонології Харківський національний медичний університет

\section{Актуальність.}

Згідно 3 аналізом доступних літературних джерел, найвищий рівень захворюваності на мультирезистентний туберкульоз у жінок припадає на репродуктивний вік (18-45 років). Проблема туберкульозу і материнства $\epsilon$ складною, бо важливим моментом $\epsilon$ вплив безпосередньо туберкульозу та хіміотерапії на перебіг вагітності, прогноз пологів та здоров'я немовлят [1].

\section{Методи.}

Був проведений ретроспективний аналіз літератури, даних pubmed [2] та клінічних випадків лікування мультирезистентного туберкульозу у вагітних жінок.

\section{Результати.}

Біологічні зміни в організмі жінки і опосередкований вагітністю іммуносупресивний стан призводять до активації латентного процесу та прогресування туберкульозу. Збільшується ризик спонтанних абортів, затримки внутрішньоутробного розвитку плоду, олігогідрамніону, неонатальної смертності [3]. Так, спостереження продемонструвало такі результати: $72 \%$ вилікуваних і без загибелі плоду або аборту. Довгостроковий ефект на дітей при застосуванні протитуберкульозних препаратів другої лінії був незначним. Загальноприйнятим $€$ факт призначення препаратів другого ряду, таких як етіонамід, циклосерін, лєвофрлоксацин, піразінамід в комплексі з ін'єкціями канаміцину упродовж що найменш 6 місяців. Рекомендовано починати терапію з другого триместру через тератогенний ефект цих препаратів [4]. Згідно 3 рекомендаціями ВООЗ таким жінкам показано проведення планового кесаревого розтину на 37-39 тижні з попереднім призначенням стероїдів для профрілактики розвитку дистрес-синдрому плода [5]. В країнах Європи та США практикується проведення патоморфологічного та бактеріологічного дослідження плаценти. Згідно з даними літератури, у більш ніж $90 \%$ випадків не виявляється наявність мікобактерій туберкульозу за умови суворого дотримання лікувального режиму. Новонароджені починають отримувати хіміопрофілактику ізоніазідом до 6 місяців [6].

\section{Висновк.}


Аналіз показав, що результати лікування мультирезистентного туберкульозу у вагітних, не гірші за результати лікування чутливого туберкульозу взагалі за умови повноцінної хіміотерапії з урахуванням ембріотоксичності деяких препаратів, чутливості мікобактерій туберкульозу, переваги використання препаратів другого ряду: зменшення частоти і враженості ускладнень гестаційного процесу, покращення перинатальних виходів. Залишається відкритим питання використання таких нових препаратів, як бедаквілін та деламанід, у зв'язку з відсутністю досвіду використання даних препаратів у вагітних при мультирезистентному туберкульозі.

\title{
Список використаних джерел:
}

1. Gandhi NR, Nunn P, Dheda K. (2010). Multidrug-resistant and extensively drug-resistant tuberculosis: a threat to global control of tuberculosis. Lancet (375), 1830-1843

2. Запорожан В. М., Польова С. П., Бажора Ю. І. (2010). Репродуктивне здоров'я жінок в умовах епідемії туберкульозу Журнал Академії Медичних Наук України (4), 734-742.

3. Корандо Н. В., Польова С. П., Семеняк А. В. (2010). Патогенетичні аспекти невиношування вагітності у жінок, хворих на туберкульоз. Буковинський медичний вісник. (2), 55-56.

4. Karim F., Johansson E., Diwan VK., Kulane A. (2011). Community perceptions of tuberculosis: Aqualit at iveex ploration from agender perspective. Public Health. (2), 84-89.

5. Ghosh K., Chowdhury JR. (2011). Tuberculosis and female reproductive health. Journal of postgr. med. (4), 307-313.

6. Польова С. П. (2009). Перебіг вагітності у хворих на туберкульоз жінок, інфікованих М. Tuberculosis сімейства Beijing. Педіатрія, акушерство та гінекологія. (71), 88-89.

\section{СТАБИЛИЗАЦИЯ РЕФРАКЦИИ ПРИ ПОМОЩИ ОРТОКЕРАТОЛОГИИ}

\author{
Дащук Андрей Андреевич \\ студент медицинского факультета \\ Харьковский национальный медицинский университет
}

Деркач Юлия Владимировна

студент медицинского факультета Харьковский национальный медицинский университет

НАУЧНЫЙ РУКОВОДИТЕЛЬ:

Панченко Николай Владимирович

д-р. мед. наук, профессор кафедры офтальмологии Харьковский национальный медицинский университет

УКРАИНА

Актуальность: на протяжении многих десятков лет отмечается широкая распространенность миопии и астигматизма, являясь важнейшими медикосоциальными проблемами. Раннее появление близорукости, быстрое прогрессирующее течение приводит к большому количеству осложнений и ранним патологиям со стороны зрения. 
Существует несколько способов коррекции миопии и астигматизма: контактная коррекция, очковая коррекция, рефрракционные операции. Пациенты, которые ведут активный способ жизни не всегда удобны в применении очки или мягкие контактные линзы. Поэтому все больше внимания в последние годы придают выбору конкретно жестким ночным линзам.

Ортокератологические жесткие газопроницаемые контактные линзы Paragon CRT для рефрракционной терапии роговицы вызывают временное уменьшение близорукости и астигматизма. Изменяя кривизну роговицы, уменьшается чрезмерная фокусирующая способность глаза. При правильном и длительном использовании линз происходит нужная фокусировка глаз для полной компенсации миопии и астигматизма.

Цель: изучение динамики клинической рефракции при ежедневном использовании ортокератологических линз на протяжении одного года, а также оценить стабилизирующий эффект на миопический глаз.

Методы и материалы: в клиническом исследовании приняли участие 10 пациентов (20 глаз): 6 женщин (60\%) и 4 мужчины (40\%), со средним возрастом 19,8 лет с разбросом от 18 до 22 лет. Процентное соотношение миопических глаз по степени тяжести: слабой степени до 3 дптр. составляло $35 \%$, средней степени от 3,25 до 6,00 дптр. - 55\%, высокой степени свыше 6 дптр. - $10 \%$.

B нашей работе мы использовали ночные линзы Paragon CRT. Каждому больному подбиралось индивидуально линзы. Ежедневным режим ношение только во время ночного сна. Линзы формируют новую переднюю поверхность роговицы, и рефрракционный эффект связан не только с уменьшением толщины эпителия в центре, но и с увеличением его толщины в среднепериферической зоне. Спустя год все пациенты делали перерыв в ношении линз около 2 недель. Когда роговица возвращалась к исходным размерам было проведена повторное измерение рефракции.

Результаты: фиксированные результаты значение клинической рефракции перед использованием линз и по истечению одного года непрерывного ношения давали нам следующее: средняя рефракция миопического глаза до начала применения была 4,21 дптр. с разбросом от 0,25 до 6,25 дптр., астигматизм был 1,04 дптр. с разбросом от 0,25 до 2,00 дптр., а спустя один год применения ортокератологии средняя рефракция миопического глаза - 4,55 дптр., варьируется от 0,25 до 2,70 дптр., когда астигматизм составлял 1,18 дптр. с границами от 0,25 до 2,15 дптр.. Разница клиничечкой рефрракции миопического глаза дает нам значение в 0,34 , а при астигматизме составляет 0,14. Спустя год уже процентное соотношение миопических глаз по степени тяжести: слабой степени - $20 \%$, средней степени - 70\%, высокой степени - 10\%. Среднее значение остроты зрения без коррекции было 0,40, а с коррекцией - 0,90. Спустя год острота зрения с коррекцией была 0,85 .

Выводы: о стабилизирующем эфрфекте можно судить по среднему увеличению миопии всего лишь на 0,34, а астигматизма на 0,14. По процентному соотношению мы видим, что слабая степень миопии уменьшилась на $15 \%$, когда средняя увеличилась на $15 \%$, а высокая осталась 
прежней. Увеличение средней степени свидетельствует о том, что только у 3 из 20 глаз произошло увеличение миопии больше чем на 0,25 дптр., а именно на двух глазах на 0,5 дптр., а на одном 0,65 дптр. У остальных 17 глазах изменений практически не было и составляли менее 0,25 дптр. Поэтому с достаточной уверенностью можно вынести такое утверждение, что ортокератология - весьма эфффективный метод лечения близорукости и астигматизма. Применение ночных линз Paragon дает возможность затормозить прогрессию, этому свидетельствует разница между полученными результатами до и после использования одного года непрерывного ношения.

\section{Список используемых источников:}

1. Шапиро Е. И. \& Казакевич Б. Г. (1998) Актуальные вопросы контактной коррекции зрения. Результаты контактной коррекции зрения при прогрессирующей миопиии. М.: медицина, 18-20.

2. Аветисов, Э.С. (1999). Близорукость. М.: Медицина, 140-142.

3. Мамиконян, В.Р. (1993). Кераторефрракционная хирургия. М.: Медицина, 120.

4. Толорея, Р.Р. (2010). Эфффективность ночных ортокератологических линз в лечении прогрессирующей миопии. М.: Медицина, 22-25 c.

\section{СУЧАСНІ ПІДХОДИ ДО ЛІКУВАННЯ ЛЕЙКОПЛАКІЇ СЕЧОВОГО МІХУРА}

Гордієнко Поліна Олексіївна

здобувач вищої освіти медичного факультету Харківський національний медичний університет

Стоян Анна Олегівна

здобувач вищої освіти медичного факультету Харківський національний медичний університет

НАУКОВИЙ КЕРІВНИК:

Демченко Владислав Миколайович канд. мед. наук, доцент кафедри урології, нефрології та андрології імені проф. А. Г. Подрєза Харківський національний медичний університет

УКРАÏHA

Актуальність. Наразі спостерігається стійке зростання пацієнтів 3 хронічним циститом, у яких при цистоскопії патологічно зміненої слизової оболонки сечового міхура можна виявити пласкоклітинну метаплазію епітелію з ороговінням. Саме пласкоклітинні метаплазовані ділянки з різним ступенем ороговіння в клініці об'єднують під одною назвою «лейкоплакія». За даними авторів метаплазія сечового міхура зустрічається у 56-82\% випадків при хронічному циститі, та має найчастіше вигляд вогнищ білого кольору, які мають чітке відмежування від незміненої слизової оболонки [1]. 
Мета. Визначити теоретичні аспекти сучасних підходів до лікування лейкоплакії сечового міхура.

Виклад матеріалу. За сучасними уявленнями лейкоплакія являє собою патологічний процес, який порушує структуру та функції багатошарового плаского епітелію, який призводить до порушення функції синтезу глікогену та проявляється стійкою тенденцією до ороговіння [1]. Це призводить до підвищення проникності епітелію сечового міхура, зниженням його здатності до перебудови при розтягненні та сприяє адгезії інфекційних агентів [2]. Наразі не існує чіткого плану лікування лейкоплакії сечового міхура, це пов'язане 3 короткочасною дією консервативної антибіотикотерапії, симптоматичною та нетривалою дією протизапальних засобів. Дія цих лікарських засобів спрямована на симптоматичне лікування проявів, але не впливає на відновлення структури патологічного метаплазованого уротелію. Хірургічне лікування, яке спрямоване на відновлення анатомічної структури у стінці сечового міхура та ліквідації дизуричних проявів призводять до значної травматизації уротелію та може пошкоджувати всю стінку сечового міхура. Період відновлення після хірургічного втручання довготривалий, під час якого можлива поява порушень сечовипускання та рецидиву захворювання [2]. Перед проведенням хірургічного втручання використовується цистоскопія.

Широко розповсюджений метод лазерної абляції, який полягає у контактній дії лазеру на тканину на невеликій глибині, при якій виникає вогнищеве випаровування тканин, за допомогою поглинання лазерного випромінювання та утворення локальної гомогенної зони карбонізації. Використання контактного методу допомагає значно зменшити зону некрозу та передбачає проводити оперативне втручання більш локально за допомогою імпульсного режиму випромінювання. Використання лазерного втручання в контактному режимі навіть при невеликій потужності дозволяє домогтися необхідного результату [3]. Процедура лазерної коагуляції є безкровною та максимально стерильною, у місці дії лазера значно зменшується зона запалення, набряку, що призводить до зменшення або повної відсутності проліферативної фрази запалення, що полегшує перебіг післяопераційного періоду та сприяє більш швидкою загоєнню раньового дефекту у місці оперативного втручання [4]. Але мінімальний об'єм коагуляції при використанні імпульсних лазерів на тканині, яка має добре кровопостачання, одночасно може призвести до недостатнього коагулюючого ефекту.

На сьогоднішній день використовують безконтактну аргоноплазмену коагуляцію (АПК), яка є особливим видом монополярної хірургії. Ї̈ суть полягає у впливі енергії електромагнітного поля на тканину, посиленої іонізованим аргоном, що допомагає локально коагулювати необхідну ділянку тканини. АПК дозволяє видалити метаплазовану слизову оболонку сечового міхура, діючи тільки на уротелій, не доходячи до власної пластинки, м'язового шару слизової. Термічна дія АПК на лейкопластичну бляшку руйнує її та призводить до загибелі уропатогенів у підслизових шарах [1].

Висновок. Наразі не існує чіткого алгоритму лікування лейкоплакії сечового міхура, адже використання методів консервативної терапії характеризується симптоматичною та короткочасною дією. Хірургічне лікування може призводити до значної травматизації уротелію та глибоких 
шарів стінки сечового міхура, але використання лазерної абляції та аргоноплазменної коагуляції $є$ безкровним та менш травматичним методом, що сприяє швидкому загоєнню та низьким відсотком ускладнень у післяопераційний період.

\section{Список використаних джерел:}

1. Царева А. В. (2009). Способ хирургического лечения лейкоплакии мочевого пузыря. Сибирский медицинский журнал (Томск), (3), 38-41.

2. Кубин Н. Д., Шпиленя Е. С. (2013). Патогенетический подход к лечению лейкоплакии мочевого пузыря. Вестник Северо-западного государственного медицинского университета им. И.И. Мечникова, (5), 63-66.

3. Слесаревская М. Н., Соколов А. В., Жарких А. В. (2012). Преимущества лазерной коагуляции лейкоплакии мочевого пузыря. Урологические ведомости, (2), 16-21.

4. Аль-шукри А. С., Жарких А. В., Слесаревская М. Н. (2013). Опыт применения лазерной аблации у женщин в постменопаузальном периоде с лейкоплакией мочевого пузыря. Нефрология, (17), 84-87. 


\section{SECTION VI. PHARMACY}

DOI 10.36074/13.12.2019.v2.12

\section{ГИПОЛИПИДЕМИЧЕСКАЯ И АНТИАТЕРОСКЛЕРОТИЧЕСКАЯ АКТИВНОСТЬ БИОЛОГИЧЕСКИ АКТИВНЫХ ВЕЩЕСТВ ЧЕСНОКА ПОСЕВНОГО}

\section{НАУЧНО-ИССЛЕДОВАТЕЛЬСКАЯ ГРУППА:}

Столетов Юрий Витальевич канд. биол. наук, доцент, доцент каф. фрармакологии Национальный фармацевтический университет

Куценко Татьяна Александровна канд. фрарм. наук, доцент, доцент каф. фрармакологии Национальный фрармацевтический университет

Уланова Вера Анатольевна канд. фрарм. наук, доцент, доцент каф. фармакологии Национальный фрармацевтический университет

Белик Галина Владимировна канд. фрарм. наук, доцент, доцент каф. фрармакологии Национальный фармацевтический университет УКРАИНА

По данным Всемирной организации здравоохранения в мире отмечается неуклонный рост заболеваний сердечно-сосудистой системы. Данные заболевания способствуют снижению качества и продолжительности жизни больных, потере трудоспособности у людей молодого и среднего возраста. В настоящее время достоверно установлено, что основной причиной развития ишемической болезни сердца и инфаркта миокарда является атеросклероз. Развитию атеросклероза способствуют многие факторы, например, гиперхолестеринемия, связанная с повышенным уровнем холестерина (XC), его основных носителей: липопротеидов низкой плотности (ЛПНП), триглицеридов (ТГ) и липопротеидов очень низкой плотности (ЛПОНП); нарушение свертываемости крови, увеличение массы тела, сахарный диабет и другие фракторы [1,2].

Лечение атеросклероза предусматривает устранение факторов, которые способствуют его развитию и использование средств симптоматической терапии. Данные препараты применяются длительно и имеют наряду со своей эфффективностью много побочных эффректов. Кроме того, курсовое лечение этими препаратами имеет высокую стоимость. Все это заставляет врача и больного отказываться от одних препаратов и переходить на другие, иногда в ущерб фармакотерапии [2, 3]. В данной ситуации выход можно найти 
в использовании фитотерапии, в частности, в применении такого лекарственного растения, как чеснок посевной. Чеснок в качестве лекарственного средства применяется очень давно. Этому способствует универсальный химический состав этого растения. В его состав входят белки, углеводы, инулин, клетчатка, эфирные масла, аллиин, макроэлементы (фосфор, магний, кальций, калий), микроэлементы (селен, сера, медь, железо, германий), витамины группы В, С, РP, Е и другие, а также фитостерины, сапонины, тиогликозиды и некоторые другие вещества [2, 4, 5, 6].

Считают, что высокая биологическая активность чеснока связана с его сероорганическими соединениями. Комплекс биологически активных веществ (БАВ) чеснока при лечении и профилактики атеросклероза оказывает, как прямое, так и непрямое действие. Это проявляется тем, что чеснок снижает уровень общего ХC, ЛПНП в крови, за счет подавления его биосинтеза в печени. В крови экспериментальных животных снижается уровень ТГ, ЛПОНП, то есть основных атерогенных факторов. Наблюдается повышение уровня антиатерогенных ЛПВП. Также происходит активация фибринолиза и подавление агрегации тромбоцитов. Отмечается замедление, а в некоторых случаях, и остановка роста атеросклеротической бляшки [7, 8].

Клиническая практика показывает, что атеросклероз возникает раньше и протекает тяжелее у больных сахарным диабетом. Опыты, проведенные на животных, показывают, что чеснок проявлял не только гипогликемическое действие, но и достаточно высокую гиполипидемическую активность. Такое действие чеснока некоторые исследователи связывают как с его сероорганическими соединениями, так и богатым витаминным, макро- и микроэлементным комплексом [7, 8].

В настоящее время в медицинской практике применяется не очень большое количество препаратов чеснока. Данные полученные на основе экспериментальных исследований на различных моделях атеросклероза у животных, показывают, что этот перечень может быть существенно расширен. В таблице представлены перспективные препараты чеснока, которые эффрективны, как для лечения, так и для профилактики атеросклероза.

Таблица 1

Препараты чеснока и их лечебное применение

\begin{tabular}{|l|l|}
\hline \multicolumn{1}{|c|}{ Препарат } & Терапия \\
\hline Чесночное масло & Лечение и профилактика атеросклероза \\
\hline Чесночный сок & Профилактика атеросклероза \\
\hline Водяной экстракт чеснока & Профилактика атеросклероза \\
\hline Гомогенат чеснока & Профилактика атеросклероза \\
\hline Таблетки чеснока (порошок) & Лечение и профилактика атеросклероза \\
\hline
\end{tabular}

Проанализировав данные таблицы, можно заключить, что препараты чеснока обладают как лечебным, так и профилактическим действием. При этом терапевтический эффект препаратов обусловлен прямым влиянием на процессы в сосудистой стенке, торможением роста атеросклеротической бляшки и снижением уровня ХС в крови. Согласно данным исследований БАВ 
чеснока способны подавлять пролиферацию атеросклеротических и других клеток, также они способны подавлять в них синтез ХС и ТГ $[6,7,8]$.

Таким образом, на основе собранных и обобщенных данных об экспериментальных исследованиях можно заключить, что чеснок благодаря своему химическому составу, обладает выраженным антиатеросклеротическим действием. Проводимые экспериментальные исследования фармакологической активности чеснока и препаратов на его основе представляют большой практический интерес, так как позволят создавать новые эффрективные и доступные препараты для лечения и профилактики атеросклероза и его осложнений.

\section{Список использованных источников:}

1. Бут, Г. (2004). Еще раз об атеросклерозе. Ліки України, (11), 9-11.

2. Гажев, Б. Н., Виноградова, Т. А., Мартынов, В. К. \& Виноградов, В. М. (1996). Лечение атеросклероза и ишемической болезни сердиа. СПб: ИКФ «МиМ экспресс».

3. Дроговоз, С. М., Гудзенко, А. П., Бутко, Я. А. \& Дроговоз, В. В. (2010). Побочное действие лекарств: учебник-справочник. Харьков: ТІТУЛ

4. Лавренова, В. К. \& Лавренова, Г. В. (2009). Современная энциклопедия лекарственных растений. Москва: Олма Медиа Групп.

5. Гоменюк, Г. А., Даниленко, В. С., Гоменюк, И. Г. \& Гоменюк, Т. Г. (2006). Энциклопедия практичной фитотерапии (Практическое применение 4260 рецептов лекарственных растений). Київ: ДСГ Лтд.

6. Кукес, В. Г. (ред.). (1999). Фитотерапия с основами клинической фармакологии. М.: Медицина.

7. Орехов, А.Н. (1998). Новые перспективы лечения атеросклероза: препараты чеснока. Терапевтический журнал, (8), 75-78.

8. Собенин, И.А., Пряшников, В.В., Куннова, Л.М., Рабинович, Е.А. \& Орехов, А.Н. (2005) Оценка эффеективности Алликора для снижения риска развития ишемической болезни сердца сердца, при первичной профилактики. Терапевтический архив, (12), 9-14. 


\section{К'ОГО}

COLLECTION OF SCIENTIFIC PAPERS

WITH PROCEEDINGS OF THE INTERNATIONAL SCIENTIFIC AND PRACTICAL CONFERENCE

«PROBLEMS AND PROSPECTS OF IMPLEMENTATION OF INNOVATIVE RESEARCH RESULTS»

December 13, 2019 • Valletta, Republic of Malta

\section{VOLUME 2}

English, Ukrainian and Russian

All papers have been reviewed

Organizing committee may not agree with the authors' point of view Authors are responsible for the correctness of the papers' text

Signed for publication 13.12.2019. Format $60 \times 84 / 16$.

Offset Paper. The headset is Arial. Digital printing.

Conventionally printed sheets 8,14 .

Circulation: 100 copies.

Printed from the finished original layout.

Contact details of the organizing committee:

21037, Ukraine, Vinnytsia, Zodchykh str. 18, office 81

NGO European Scientific Platform

Tel.: +38 $0981948380 ;+380981956755$

E-mail: info@ukrlogos.in.ua

URL: www.ukrlogos.in.ua 